IB1-IIA1 có kết quả sống thêm tốt, an toàn và các biến chứng trong giới hạn chấp nhận được.

\section{TÀI LIÊU THAM KHẢO}

1. J. Ferlay, I. Soerjomataram, R. Dikshit, et al. (2015), "Cancer incidence and mortality worldwide: sources, methods and major patterns in GLOBOCAN 2012", Int J Cancer, 136(5), tr. E359-86.

2. San-Gang Wu, Wen-Wen Zhang, Zhen-Yu He, et al (2017), "Comparison of survival outcomes between radical hysterectomy and definitive radiochemotherapy in stage IB1 and IIA1 cervical cancer", Cancer Manag Res. 2017; 9: 813-819.

3. Nguyễn Văn Tuyên. (2008), "Nghiên cứu điều tri ung thư cổ tứ cung giai đoạ IB - II bằng phương pháp phâu thuật kết hợp với xạ trị và một số yếu tố tiên lượng", Luận án Tiến sỹ Y học, Học viên Quân Y.

4. Nguyển Văn Hà (2016), "Đánh giá kết quả điều trị ung thư cổ tử cung giai đoạn IB1 bằng phẫu thuật triệt căn", Luân văn tốt nghiệp bác sỹ nội trú, Đại học Y Hà Nội.

5. Võ Vằn Kha, Võ Đăng Hùng, Huỳnh Quyết Thắng và các công sự. (2009), "Nghiên cứu điều trị ung thư cổ tử cung giai đoạn IB-IIA bằng phâuu thuật đầu tiên tại bệnh viên đa khoa Cần Thơ ", Y hoc TंP Hồ Chí Minh, 10(4).

6. Nguyển Quốc Trực, Tạ Thanh Liêu, Phạm Văan Bưng và các cộng sự. (2006), "Điều trị phấu thuât ung thư cồ tư cung giai đoạn IB1", Y hoc TP Hồ Chí Minh, 10(4).

7. C. M. Ho, T. Y. Chien, S. H. Huang, et al (2004), "Multivariate analysis of the prognostic factors and outcomes in early cervical cancer patients undergoing radical hysterectomy", Gynecol Oncol, 93(2), pp. 458-64.

8. F. Landoni, A. Maneo, A. Colombo và các cộng sự. (1997), "Randomised study of radical surgery versus radiotherapy for stage Ib-IIa cervical cancer", Lancet, 350(9077), tr. 535-40

\title{
ĐÁNH GIÁ KẾT QUẢ PHẪU THUÂTT U TUYẾN GIÁP KHÔNG ĐẶT DẪN LƯU TẠI BỆNH VIỆN K
}

\author{
Phạm Văn Hoàn ${ }^{1}$, Nguyễn Văn Hiếu ${ }^{1}$, Nguyễn Xuân Hậu ${ }^{1}$, \\ Ngô Xuân Quý2, Ngô Quốc Duy ${ }^{2}$
}

\section{TÓM TẮT}

Mục tiêu nghiên cứu: Đánh giá kết quả phẫu thuật u tuyến giáp không đặt dẫn lưu tại bệnh viện $\mathrm{K}$ giai từ năm 2019 đến 2021. Đối tượng và phướng pháp nghiên cứu: Nghiên cứu mô tả cắt ngang, trên các bênh nhân u tuyến giáp được phẫu thuật không đặt dần lưu tại bệnh viện $\mathrm{K}$ từ T1/2019-T8/2021. Theo dỗi các biến chứng sau phầu thuật (tụ dịch, tụ máu, chảy máu, suy cận giáp, nói khàn), mức độ đ̛̣u sau phẫu thuật, thời gian nằm viện. Kết quả: Phẫu thuật không dẫn lưu trền 130 bệnh nhân, tuổi trung bình là $43.5 \pm 10.9$ tuổi. Biến chứng sau mổ ghi nhần $6.9 \%$ bệnh nhân có tu dịch, $6.2 \%$ nói khàn tam thời và $4.6 \%$ suy cận giáp tạm thời, $3.8 \%$ tu máu sau mổ, $0.8 \%$ có chảy máu cần mổ lại. Mức độ đau sau phấu thuật trung bình ngày 0 là $3.18 \pm 0.41$, ngày 1 là $2.4 \dot{8} \pm 0.56$. Thời gian nằm viên trung binh là 4.78 0.76 . Kết luận: Phẫu thuật không đặt dẫn lưu trong các trường hợp u tuyến giáp không kèm theo vét hạch cổ bên an toàn, rút ngắn thời gian nằm viện, thuận tiện cho bệnh nhân trong quá trình hậu phẩu, biến chứng sau phẫu thuật xảy ra với tỷ lệ thẩp, đa phân tự hổi phục, không có trường hợp nằo kéo dài quá 6 tháng.

Từ khóa: U tuyến giáp, phẫu thuật, không dẫn lưu.

${ }^{1}$ Trường Đại học Y Hà Nọi

${ }^{2}$ Bênh viên $K$ cơ sở Tân Triều

Chịu trách nhiệm chính: Phạm Văn Hoàn

Email: rainstorm1108@gmail.com

Ngày nhân bài: 9.8.2021

Ngày phản biên khoa hoc: 5.10 .2021

Ngày duyệt bài: 14.10.2021

\section{SUMMARY}

EVALUATION OF THYROID SURGERY RESULTS WITHOUT DRAINAGE AT VIET

NAM NATIONAL CANCER HOSPITAL

Objective:To evaluate the outcomes of thyroid surgery without drainage at Viet Nam national cancer hospital from 2019 to 2021 . Materials and method: A cross-sectional descriptive study, on thyroid tumor patients who underwent surgery without drainage at $\mathrm{K}$ hospital from $1 / 2019$ to $8 / 2021$. Monitor postoperative complications (fluid collection, hematoma, bleeding, hypoparathyroidism, hoarseness, pain level after surgery, hospital stay). Results: Surgery without drainage on 130 patients, the mean age of patients in the study was $43.5 \pm 10.9$ years old. Postoperative complications recorded $6.9 \%$ of patients with fluid collection, $6.2 \%$ of patients with temporary hoarseness and $4.6 \%$ of temporary hypoparathyroidism, $3.8 \%$ of postoperative hematoma, $0.8 \%$ of bleeding requiring reoperation. The mean postoperative pain on day 0 was $3.18 \pm 0.41$, day 1 was $2.48 \pm 0.56$. The mean hospital stay was $4.78 \pm 0.76$. Conclusions: Surgery without drainage in cases of thyroid tumors without associated cervical lymph node dissection is safe, shortens hospital stay and convenient for patients in the postoperative period, bleeding complications that require reoperation only occur in $0.8 \%$ of patients, other complications after surgery mostly resolved spontaneously, with no cases lasting > 6 months.

Keywords: Thyroid tumor, surgery, without drainage.

\section{I. ĐẠT VẤN ĐỀ}


U tuyến giáp là bệnh hay gặp nhất trong số các khối u của tuyến nội tiết, bao gồm u tuyến giáp lành tính và ung thư tuyến giáp. Trong đó, u tuyến lành tính chiếm trên $95 \%$ các trường hợp u tuyến giáp, bệnh gặp chủ yếu ở nữ giới, người lớn thường gặp hơn trẻ em. Đối với ung thư tuyến giáp theo GLOBOCAN 2018, mỗi năm có 567.000 trường hợp mắc mới, đứng thứ 9 về tỷ lệ mắc ở cả 2 giới, đứng thứ 5 nếu tính riêng ở nữ giới, tỷ lệ nữ/nam là $3 / 1^{1}$. Phẫu thuật hiện nay vẩn phương pháp điều trị chính trong bệnh lý ung thư tuyến giáp và giữ vai trò nhất định trong các bênh lý u tuyến giáp lành tính. Trước đây, các phẫu thuật viên ưu tiên việc đặt dẫn lưu sau phẫu thuật tuyến giáp với mục đích theo dõi chảy máu sau phẫu thuật, dẫn lưu lượng máu chảy giúp cứu sống bệnh nhân trong những trường hợp chảy máu cấp tính sau mổ gây chèn ép khí quản, cũng như hạn chế tình trạng tụ máu dưới da, tụ dịch sau mổ 2 . Tuy nhiển, một số nghiên cứu gần đây chỉ ra việc đặt dẫn lưu không làm giảm tỷ lệ biến chứng sau phẫu thuật, đồng thời, việc đặt dẫn lưu sau mổ còn làm bệnh nhân đau hơn sau phẫu thuâtt cũng như kéo dài thời gian nằm viện ${ }^{3,4}$. Tại bệnh viện $\mathrm{K}$ phẫu thuật không đặt dẫn lưu đã được triển khai trong những nămm gần đây, tuy nhiên chưa có nghiên cứu nào về kết quả của phương pháp này. Vì vậy chúng tôi thực hiện đề tài: "Đánh giá kêt quả phẫu thuật u tuyển giáp không đặt dẫn lưu tại bệnh viện K".

\section{II. ĐỐI TƯỢNG VÀ PHƯƠNG PHÁP NGHIÊN CỨU}

2.1. Thời gian và địa điểm:Nghiên cứu tiến hành tại bệnh viện $K$ từ1/2019 đến T8/2021.

\section{2. Đối tượng nghiên cứu}

\subsubsection{Tiêu chuẩn chọn bệnh nhân} nghiên cứu:

- Tất cả những bệnh nhân u tuyến giáp được phẫu thuậttheo phác đồ bệnh viện K:

+ Cắt tuyến giáp toàn bộ.

+ Cắt thùy kèm eo tuyến giáp.

+ Cắt thùy tuyến giáp.

- Phẫu thuật không sử dụng dẫn lưu.

- Chấp nhận tham gia nghiên cứu.

- Có hồ sơ nghiên cứu

\subsubsection{Tiêu chuẩn loại trừ:}

- Bệnh nhân phẫu thuật ung thư tuyến giáp có vét hạch cổ bên, hoặc cắt rộng tổ chức xung quanh tuyến giáp.

- U tuyến giáp tái phát được phẫu thuật lại.

- Bướu giáp thòng.

- Bệnh nhân có rối loạn đông máu, hay đang sử dụng thuốc chống đông.
2.3. Cõ̃ mẫu: Cõ̃ mẫu thuận tiện.

2.4. Phương pháp nghiên cứu: Nghiên cứu mô tả cắt ngang.

2.5. Cách thức tiến hành:

- Thu thập hồ sơ bệnh án theo mẫu bệnh án.

- Chọn bệnh nhân đủ tiêu chuẩn vào nghiên cứu.

- Ghi nhận thông tin về lâm sàng, cận lâm sàng, chẩn đoán, phương pháp điều trị của các bệnh nhân tham gia nghiên cứu.

- Theo dõi các biến chứng sau phẫu thuật, mức độ đau, thời gian nằm viện, mức độ hài lòng của người bệnh.

\subsection{Phân tích số liệu:}

- Thu thập các số liệu dựa trên mẫu bệnh án nghiên cứu.

- Số liệu nghiên cứu được mã hoá, nhập, xử lý và phân tích trên máy tính, sử dụng phần mềm SPSS 20.0.

\section{7. Đạo đức nghiên cứu:}

- Việc tiến hành nghiên cứu có xin phép và được sự đồng ý của lãnh đạo Bệnh viện $\mathrm{K}$ và gia đình bệnh nhân.

- Thông tin về tình trạng bệnh và thông tin cá nhân của bệnh nhân được giữ bí mật.

- Các thông tin thu được của đối tượng chỉ nhằm mục đích nghiên cứu.

\section{KẾT QUẢ NGHIÊN CỨU}

Từ tiêu chuẩn lựa chọn, chúng tôi thu thập được 130 bệnh nhẩn đưa vào nghiên cứu bao gồm 31 trường hợp u giáp lành và 99 trường hợp ung thư tuyến giáp.

\section{1 Đặc điểm đối tượng nghiên cứu}

Bảng 1. Đặc điểm tuổi

\begin{tabular}{|c|c|c|c|}
\hline $\begin{array}{c}\text { Đặc } \\
\text { điểm }\end{array}$ & $\begin{array}{c}\text { Tuổi trung } \\
\text { bình }\end{array}$ & $\begin{array}{c}\text { Cao } \\
\text { nhất }\end{array}$ & $\begin{array}{c}\text { Thấp } \\
\text { nhất }\end{array}$ \\
\hline Tuổi & $43.5 \pm 10.9$ & 70 & 14 \\
\hline
\end{tabular}

Nhận xét: Tuối mắc bệnh trung bình là 43.5 \pm 10.9 tuổi, cao nhất là 70 tuổi, thấp nhất là 14 tuổi. Lứa tuổi thường gặp nhất từ 35-50 tuổi chiếm $56.9 \%$.

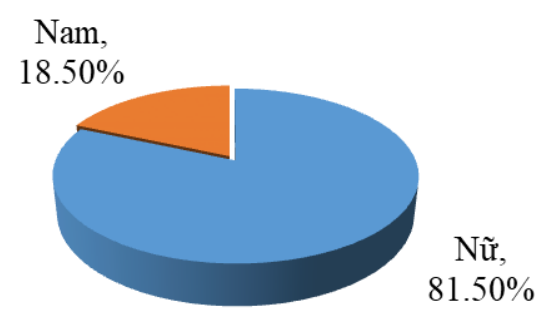

Biểu đồ. 1.Đặc điểm về giới

Nhận xét: Bệnh gặp chủ yếu ở nữ giới chiếm 81.5\% (106), tỷ iệ nứ/nam là 4.4/1.

Bảng 2. Phương pháp phấu thuật. 


\begin{tabular}{|c|c|c|}
\hline $\begin{array}{c}\text { Phân loại phâu } \\
\text { thuạat }\end{array}$ & $\begin{array}{c}\text { Số bệ̂nh } \\
\text { nhẩn }\end{array}$ & Tỷ lệ \\
\hline Cắt TGTB & 33 & $25.4 \%$ \\
\hline Cắt thùy $\pm e 0$ & 97 & $74.6 \%$ \\
\hline Tống & $\mathbf{1 3 0}$ & $\mathbf{1 0 0} \%$ \\
\hline
\end{tabular}

Nhận xét: Tỷ lệ cắt thùy eo hoặc cắt thùy chiếm tỷ lệ $74.6 \%$, cắt tuyến giáp toàn bộ ở 25.4\% bênh nhân.

\subsection{Mức độ đau sau phẫu thuật}

Bảng 3. Mức độ đau sau mổ theo phân nhóm phẫu thuật.

\begin{tabular}{|c|c|c|c|c|}
\hline Thời điểm hậu phẩu & Cắt TGTB & Cắt thùy \pm eo & Tổng & $\mathbf{P}$ \\
\hline Ngày 0 & $3.42 \pm 0.5$ & $3.1 \pm 0.33$ & $3.18 \pm 0.41$ & 0.00 \\
\hline Ngày 1 & $2.72 \pm 0.63$ & $2.4 \pm 0.49$ & $2.48 \pm 0.56$ & 0.011 \\
\hline
\end{tabular}

Nhận xét: - Mức độ đau trung bình sau mố ngày 0 của các bệnh nhân không dấn lưu là $3.18 \pm 0.41$, mức độ đau ngày 1 trung bình là $2.48 \pm 0.56$.

- Bệnh nhân phẫu thuật cắt TGTB có mức độ đau trung bình sau phẫu thuật cao hơn có ý nghĩa thống kê so với các bệnh nhân được phẫu thuật cắt thùy \pm eo, với $p<0.05$.

\subsection{Biến chứng sau phẫu thuật}

Bảng 4. Tý lệ biến chứng theo phân nhóm phẫu thuật

\begin{tabular}{|c|c|c|c|c|}
\hline Biến chứng & Căt TGTB & Căt thừy \pm Eo & $\mathbf{p}$ & Tống \\
\hline Tụ dịch: $\begin{array}{c}\text { Không } \\
\text { Có }\end{array}$ & $\begin{array}{l}28(84.8 \%) \\
5(15.2 \%)\end{array}$ & $\begin{array}{c}93(95.9 \%) \\
4(4.1 \%)\end{array}$ & 0.046 & $\begin{array}{l}121(93.1 \%) \\
9(6.9 \%)\end{array}$ \\
\hline $\begin{array}{c}\text { Tụ máu dưới da: Không } \\
\text { Có }\end{array}$ & $\begin{array}{c}31(93.9 \%) \\
2(6.1 \%)\end{array}$ & $\begin{array}{c}94(96.9 \%) \\
3(3.1 \%)\end{array}$ & 0.6 & $\begin{array}{c}125(96.2 \%) \\
5(3.8 \%)\end{array}$ \\
\hline Chảy máu: $\begin{array}{c}\text { Không } \\
\text { Có }\end{array}$ & $\begin{array}{c}33(100 \%) \\
0\end{array}$ & $\begin{array}{c}96(99 \%) \\
1(1 \%)\end{array}$ & 1.0 & $\begin{array}{c}129(99.2 \%) \\
1(0.8 \% \%)\end{array}$ \\
\hline $\begin{array}{c}\text { Nói khàn tạm thời: Có } \\
\text { Không }\end{array}$ & $\begin{array}{l}5(15.2 \%) \\
28(84.8 \%)\end{array}$ & $\begin{array}{c}3(3.1 \%) \\
94(96.9 \%)\end{array}$ & 0.025 & $\begin{array}{c}122(93.8 \%) \\
8(6.2 \%)\end{array}$ \\
\hline Suy cận giáp tạm thởi: Không & $\begin{array}{c}29(87.9 \%) \\
4(12.1 \%)\end{array}$ & $\begin{array}{c}95(97.9 \%) \\
2(2.1 \%)\end{array}$ & 0.036 & $\begin{array}{l}1245.4 \%) \\
6(4.6 \%)\end{array}$ \\
\hline
\end{tabular}

Nhận xét: - Tụ dịch sau mổ là biến chứng thường gặp nhất xảy ra ở 9 bệnh nhân (6.9\%). Trong đó tụ dịch xảy ra với tỷ lệ $15.2 \%$ ở nhóm cắt TGTB cao hơn có ý nghĩa thống kê so với chỉ $4.1 \%$ ở nhóm cắt thùy \pm eo giáp, $p=0.046$.

- Biến chứng tụ máu dưới da gặp ở 5 bệnh nhân (3.8\%). Không có sự khác biệt về tỷ lệ biến chứng tụ máu dưới da giữa các phương pháp phẫu thuật khác nhau $\mathrm{p}=0.6$

- Chúng tôi chỉ ghi nhận $1(0.8 \%)$ trường hợp chảy máu sau mổ trên bệnh nhân được phầu thuật cắt thùy và eo giáp.

- Biến chứng nói khàn tạm thời xảy ra ở 6.2\% bệnh nhân, chủ yếu xảy ra trên nhóm bệnh nhân được phẫu thuật cắt tuyến giáp toàn bộ chiếm $15.2 \%$ cao hơn có ý nghĩa thống kê so với nhóm cắt thùy $\pm e o, p=0.025$.

- Biến chứng suy cận giáp tạm thời xảy ra ở $4.6 \%$ bệnh nhân, chủ yếu trên nhóm bệnh nhân được phẫu thuật cắt tuyến giáp toàn bộ chiếm $12.1 \%$ cao hơn có ý nghĩa thống kê so với ở nhóm cắt thùy \pm eo là $2.1 \%, p=0.036$.

- Không ghi nhận trường hợp bệnh nhân suy cận giáp vĩnh viễn, nói khàn kéo dài và nhiễm trùng vết mổ trong nhóm nghiên cứu.

3.4. Thời gian nằm viện. Thời gian nằm viện trung bình ở nhóm bệnh nhân không dẫn lưu là $4.78 \pm 0.76$ (ngày) ngắn nhất 3 ngày, dài

nhất 7 ngày.

\section{BÀN LUẬN}

Mọi lứa tuổi đều có thể gặp u tuyến giáp, trong nghiên cứu của chúng tồi bệnh nhân trẻ tuổi nhất ghi nhận là 14 tuổi, lớn tuổi nhất là 70 tuổi, tuổi trung bình bệnh nhân trong nghiên cứu là 43.5 \pm 10.9 tuổi, trong đó lứa tuổi hay gặp nhất là 35-50 tuổi chiếm tỷ lệ 56.9\%, kết quả này của chúng tôi tương đồng với các tác giả trong nước khác ${ }^{4,5}$.

Bệnh chủ yếu xảy ra ở nữ giới, trong nghiên cứu của chúng tôi nhóm bệnh nhân nữ chiếm $81.5 \%$, tỷ lệ nữ/nam $=4.4 / 1$. Kết quả này cũng phù hợp với nghiên cứu của Nguyền Thị Khánh Ly (2013) nữ giới chiếm $85.9 \%$, tỷ lệ nữ/nam $6 / 1^{5}$.

Biến chứng tụ dịch sau mổ là biến chứng thường gặp nhất tỷ lệ $6.9 \%$. Trong đó chủ yếu ở xảy ra ở nhóm bệnh nhân được phẫu thuật cắt giáp toàn bộ với tỷ lệ $15.2 \%$ cao hơn có ý nghĩa thống kê so với việc cắt thùy \pm eo giáp, $\mathrm{p}=0.046$. Nghiên cứu của Nguyễn Xuân Hiền (2019) tỷ lệ tụ dịch ở nhóm phẩu thuật không đặt dẫn lưu là $9.5 \%$, trong đó thường gặp nhất ở nhóm cắt tuyến giáp toàn bộ và vét hạch nhóm VI tỷ lê $22 \%{ }^{4}$.

Biến chứng tụ máu dưới da được ghi nhận ở 5 bệnh nhân (3.8\%), không có sự khác biệt về tỷ 
lệ biến chứng tụ máu dưới da giữa các phương pháp phẫu thuật. Kết quả này tương đồng với nghiên cứu của Nguyễn Xuân Hiền (2019) tỷ lệ biến chứng tụ máu dưới da ở nhóm không dẫn lưu là $4.76 \%{ }^{4}$.

Trong nghiên cứu của chúng tôi ghi nhận 1 trường hợp $(0.8 \%)$ bệnh nhân có biến chứng chảy máu sau mổ trên bệnh nhân được phẫu thuật cắt thùy và eo tuyến giáp. Bệnh nhân được phát hiện giờ thứ 4 sau mổ, tình trạng bệnh nhân lúc phát hiện với biểu hiện tức nặng và sưng nề vùng cổ được xử trí cầm máu cấp cứu sau đó. Theo Deveci (2013), nghiên cứu trên 400 bệnh nhân gồm 2 nhóm có dẫn lưu và không dẫn lưu, ghi nhận 2 trường hợp chảy máu ở nhóm không dẫn lưu (1\%), 1 trường hợp ở nhóm đặt dẫn lưu $(0.5 \%)$. Bệnh nhân biểu hiệu với triệu chứng khó thở và sưng nề vùng cổ mặc dù dẫn lưu hoàn toàn sạch, cả 3 trường hợp đều sảy ra 2 giờ đầu sau mổ. Tác giả cũng đưa ra kết luận việc đặt dẫn lưu không ngăn ngừa biến chứng chảy máu sau mổ hay giúp phát hiện sớm tình trạng này ${ }^{6}$.

Suy cận giáp sau mổ ghi nhận ở 6 trường hợp (chiếm 4.6\%) trong đó ở chủ yếu xảy ra trền bệnh nhân được phẫu thuật cắt tuyến giáp toàn bộ: chiếm $12.1 \%$ cao hơn có ý nghĩa thống kê so với nhóm được phẫu thuật cắt thùy \pm eo giáp chỉ $2.1 \%$.Theo Nguyễn Xuân Hiền (2019) tỳ lệ biến chứng suy cận giáp trên bệnh nhân không đặt dẫn lưu sau phấu thuật là $4.8 \%$, tất cả trường hợp bệnh nhân đều ghi nhận ở nhóm được cắt tuyến giáp toàn bộ và vét hạch cổ VI ${ }^{4}$. Tỷ lệ biến chứng suy tuyến cận giáp theoDeveci (2013) là $3,5 \% \%^{6}$. Như vậy tỷ lệ biến chứng suy cận giáp trên bệnh nhân phẫu thuật không đặt dẫn lưu trong nghiên cứu của chúng tôi tương đương với các kết quả của tác giả trong và ngoài nước.

Biến chứng nói khàn xảy ra ở 8 trường hợp (6.2\%) trong đó chủ yếu ở nhóm bệnh nhân cắt tuyến giáp toàn bộ, tuy nhiên không ghi nhận trường hợp nào suy cận giáp kéo dài trên 6 tháng. Theo y văn tỷ lệ biến chứng liệt dây thanh quản quă̆t ngược tạm thời dao động từ $1 \%$ đến $5 \%$ và liệt dây thanh quản vĩnh viễn từ $0,1 \%-1,8 \% 7$. Nghiên cứu của Nguyễn Xuân Hiền (2019) tỷ lệ nóikhàn tạm thời ở nhóm bệnh nhân không đặt dẫn lưu là $7.1 \%$, chủ yếu ghi nhân ở nhóm phẫu thuật cắt tuyến giáp toàn bộ

Trong nghiên cứu của chúng tôi không ghi nhận trường hợp nào có biến chứng nhiểm khuẩn. Tuy nhiên, theo nghiên cứu của Woods (2014) trên 2939 bệnh nhân tỷ lệ nhiễm trùng vết mổ ở nhóm dẫn lưu là $23 / 1009(2,3 \%)$, ở nhóm không dẫn lưu là $7 / 1026(0,7 \%)$ sự khác biệt có ý nghĩa thống kê với RR (95\%CI): 2,53 $(1,23-5,21)^{8}$.

Thời gian nằm viện trung bình trong nghiên cứu của chúng tôi là $4,78 \pm 0,76$ ngày, kết quả này của chúng tôi cố sự tương đồng so với nghiên cứu của Nguyễn Xuân Hiên (2019) thời gian nằm viện trung bình ở nhóm không dẫn lưu là $4.7 \pm 0.5$ ngày ngắn hơn có ý nghĩa thống kê so với $6.2 \pm 0.7$ ngày ở nhóm có sử dụng dẫn lưư ${ }^{4}$. Theo nghiên cứu của Lee (2006) thời gian nằm ở nhóm không dẫn lưu là $6,8 \pm 1,4$ ngày 3 .

\section{KẾT LUẬN}

Phẫu thuật không đặt dẫn lưu trong các trường hợp u tuyến giáp không kèm theo vét hạch cổ bên an toàn, rút ngắn thời gian nằm viện, thuận tiện cho bệnh nhân trong quá trình hậu phấu, biến chứng chảy máu cần mổ lại chỉ xảy ra ở $0,8 \%$ bệnh nhân, các biến chứng khác sau phẫu thuật đa phần tự hồi phục không có trường hợp nào kéo dài $>6$ tháng.

\section{TÀI LIÊU THAM KHẢO}

1. Bray F, Ferlay J, Soerjomataram I, Siegel RL, Torre LA, Jemal A. Global cancer statistics 2018: GLOBOCAN estimates of incidence and mortality worldwide for 36 cancers in 185 countries. CA Cancer J Clin. 2018;68(6):394-424. doi:10.3322/ caac. 21492

2. Ardito G, Revelli L, Guidi ML, et al. [Drainage in thyroid surgery]. Ann Ital Chir. 1999;70(4):511516; discussion 516-517.

3. Lee SW, Choi EC, Lee YM, Lee JY, Kim SC, Koh YW. Is Lack of Placement of Drains After Thyroidectomy With Central Neck Dissection Safe? A Prospective, Randomized Study. The Laryngoscope. 2006;116(9):1632-1635. doi: 10.1097/01.mlg.0000231314.86486.be

4. Nguyễn Xuân Hiên (2019). Đánh giá kết quả phâu thuật u tuyến giáp không sử dụng dẫn lưu tại bệnh viện Đại học Y Hà Nội, Luận văn thạc sỹ y học, Trường đại hớc Y Hà Nội.

5. Nguyễn Thi Khánh Ly (2013). Nhân Xét Đăc Điểm Lâm Sàng, Cận Lâm Sàng và Kết Quả Điểu Trị Khối u Tuyến Giáp Tại Bệnh Viện Đại Học Y Hà Nội, Luận Văn Tốt Nghiệp Bác Sĩ Đạa Khoa, Trường Đại Học Y Hà Nội.

6. Deveci U, Altintoprak F, Sertan Kapakli M, et al. Is the Use of a Drain for Thyroid Surgery Realistic? A Prospective Randomized Interventional Study. J Thyroid Res. 2013;2013:285768. doi: $10.1155 / 2013 / 285768$

7. Eisele D.W and Smith R.V (2009). Complications of Thyroid Surgery. Complications in Head and Neck Surgery, Second Edition, Mosby/Elsevier, Philadelphia. 493-515.

8. Woods RSR, Woods JFC, Duignan ES, Timon C. Systematic review and meta-analysis of wound drains after thyroid surgery. Br J Surg. 2014;101(5):446-456. doi:10.1002/bjs.9448 


\title{
TÁC DƯNG GIẢM ĐAU CỦA ĐIỆN CHÂM KẾT HỢP PARAFIN TRÊN BỆNH NHÂN HộI CHỨNG CỔ VẢI TAY DO THOÁI HÓA CộT SỐNG Cổ
}

\author{
Phan Thị Hồng Giang*, Nguyễn Thị Thanh Tú**
}

\section{TÓM TẮT}

Đánh giá tác dụng giảm đau của điện châm kết hợp đắp parafin trên bệnh nhân hội chứng cổ vai tay do thoái hoá cột sống cổ. Đối tượng: 60 bệnh nhân được chẩn đoán hội chứng cổ vai tay do thoái hoá cột sống cổ điều trị tại khoa Nội 4, khoa Châm cứu và Phục hồi chức năng - Bệnh viện Y học cổ truyền Bộ Công an từ tháng 09 nằm 2020 đến tháng 08 năm 2021. Phương pháp: Nghiên cứu can thiệp, có đối chứng: 30 bệnh nhân nhóm nghiên cứu được điện châm kết hợp đắp parafin, 30 bệnh nhân nhóm chứng được điện châm. Kết quả: Sau 15 ngày điều trị, nhóm nghiên cứu có điểm VAS trung bình giảm từ 5,5 $\pm 1,38$ xuống $1,9 \pm 0,8$, nhóm chứng giảm từ $5,3 \pm$ 1,53 xuống $4,0 \pm 1,31$. Sự khác biệt trước sau điều trị của 2 nhóm có ý nghĩa với $p<0,05$. Hiêuu suất giảm điểm đau VAS của nhóm nghiên cứu tại thời điểm D7 $(1,90 \pm 0,62$ điểm) và $\mathrm{D} 15(3,6 \pm 1,00$ điểm) cao hơn nhóm chứng ở cùng thời điểm với $p<0,05$. Kết luận: điện châm kết hợp đắp parafin có tác dụng giảm đau trền bệnh nhân hội chứng cổ vai tay do thoái hoá cột sống cổ. Sự khác biệt có ý nghĩa thống kê so với nhóm chứng điện châm đơn thuần.

Tư khóa: hội chứng cổ vai tay, thoái hóa cột sống cổ, đắp parafin, điện châm.

\section{SUMMARY}

ANALGESIC OF ELECTROACCUPUNTURE COMBINED WITH PARAFIN THERAPY ON CERVICAL SCAPULOHUMERAL SYNDROME PATIENTS DUE TO CERVICAL SPONDYLOSIS

Objectives: To evaluate the analgesic effect of electroacupuncture combined with parafin on cervical scapulohumeral syndrome patients due to cervical spondylosis. Subjects: 60 cervical scapulohumeral syndrome patients due to cervical spondylosis were treated at Internal Medicine Department 4, Department of Acupuncture and Rehabilitation in Traditional Medicine Ministry of Public Security from September 2020 to August 2021. Methods: Controlled clinical trials: 30 patients of the study group were administered electroacupuncture combined with paraffin, 30 patients of the control group were administered electroacupuncture. Results: After 15 days of treatment, the mean's VAS value of the study group decreased from $5.5 \pm 1.38$ to $1.9 \pm 0.8$, the mean's VAS value of the control group decreased from $5.3 \pm 1.53$ to $4.0 \pm 1.31$. The difference before and

*Bệnh viện Y học cổ truyền Bộ công an

**Trường Đại học Y Hà Nội

Chịu trách nhiệm chính: Nguyễn Thị Thanh Tú

Email: thanhtu@hmu.edu.vn

Ngày nhận bài: 6.8 .2021

Ngày phản biên khoa hoc: 5.10 .2021

Ngày duyệt bài: 13.10.2021 after treatment of the 2 groups was significant with $p$ $<0.05$. VAS pain reduction efficiency of the study group at the time of $D 7(1.90 \pm 0.62$ points $)$ and $D 15$ (3.6 \pm 1.00 points) was higher than the control group at the same time with $p<0.05$. Conclusions: Electroacupuncture combined with paraffin had the efficacy in reducing pain of cervical spine on cervical scapulohumeral syndrome patients due to cervical spondylosis. The difference was statistically significant compared with the control group.

Keywords: cervical scapulohumeral syndrome, cervical spondylosis, parafin, electroacupuncture

\section{I. ĐĂT VẤN ĐỀ}

Hội chứng cổ vai tay do thoái hoá cột sống cổ (THCSC) là bệnh lý khá phổ biến tại Việt Nam cũng như trên thế giới. Bệnh chiếm từ 70 đến $80 \%$ trong các bênh lý THCSC. Bệnh tuy không nguy hiểm đến tính mang nhưng ảnh hưởng nhiều đến chất lượng cuộc sống [6]. Hội chứng cổ vai tay do THCSC được điều trị bằng nhiều phương pháp nhằm mục đích giảm các triệu chứng bệnh. Tuỳ mức độ của bệnh mà $Y$ học hiện đại (YHHĐ) sử dụng thuốc giảm đau, giã̉n cớ, phong bế thần kinh, kết hợp phục hồi chức năng như hồng ngoại, siêu âm, sóng ngắn, đắp parafin... [2],[7]. Bên cạnh đó, y học cổ truyền (YHCT) cũng sứ dụng các phương pháp không dùng thuốc như: điện châm, nhĩ châm, cứu ngải, xoa bóp bấm huyệt và sử dụng thuốc cổ truyền để điều trị hội chứng này [5]. Trong thực tế, việc kết hợp giửa các phương pháp khổng dùng thuốc của YHHĐ và YHCT nhằm nâng cao hiêu quả điều trị luôn là mục tiêu của các thây thuốc lâm sàng. Với mong muốn đạt được kết quả điều trị tốt cho bệnh, nhân chúng tôi áp dụng phương pháp điện châm kết hợp đắp parafin để điều trị cho bệnh nhân mắc hội chứng cổ vai tay do THCSC. Để khẳng định kết quả phối hợp điều trị một cách khoa học, chúng tôi tiến hành nghiên cứu đề tài với mục tiêu: Đánh giá tác dụng giảm đau của điên châm kêt hợp đắp parafin trên bệnh nhân hội chứng cổ vai tay do thoái hoá cột sống cố.

\section{II. ĐỐI TƯỢNG VÀ PHƯƠNG PHÁP NGHIÊN CỨU \\ 2.1. Đối tượng nghiên cứu \\ 2.1.1. Tiêu chuẩn lựa chọn bệnh nhân:} Bênh nhân được chẩn đoán hội chứng cổ vai tay do THCSC, mức độ đau VAS $\leq 7$ điểm, bệnh nhân thuộc thể phong hàn thấp kèm can thận hư theo y học cổ truyền. 
2.1.2 Tiêu chuẩn loại trừ bệnh nhân: Bệnh nhân hội chứng cổ vai tay do THCSC kèm mắc các bệnh lý thực thể khác như lao, ung thư, bệnh lý cấp tính, có chỉ định phẫu thuật, bệnh lý ngoài da vùng cổ vai. Bệnh nhân không đồng ý tham gia nghiên cứu và không tuân thủ điêu trị.

\subsection{Phương pháp nghiên cứu}

2.2.1. Thiết kế nghiên cứu: thử nghiệm lâm sàng mở, so sánh trước và sau điều trị và so sánh với nhóm đối chứng.

Chọn cỡ mẫu chủ đích gồm 60 bệnh nhân đáp ứng tiêu chuẩn lựa chọn và tiêu chuẩn loại trừ. Bệnh nhân được chia thành 2 nhóm, ghép cặp tương đồng về tuổi, giới và mức độ đau theo thang điểm VAS:

- Nhóm nghiên cứu: 30 bênh nhân điều trị bằng phương pháp điện châm kết hợp đắp parafin.

- Nhóm đối chứng: 30 bệnh nhân điều trị bằng phương pháp điện châm.

\subsubsection{Chất liệu nghiên cứu}

- Parafin: Miếng parafin màu trắng, kích thước $20 \times 30 \mathrm{~cm}$, độ dày $2 \mathrm{~cm}$ đắp lên vùng cố, vai bên đau của bệnh nhân. Mỗi ngày đắp 30 phút/ 1 lần trong 15 ngày.

- Công thức huyệt điện châm: theo quy trình kỹ thuật của Bộ Y tế [3].

+ Châm tả các huyệt Phong Trì, Kiên ngung, Kiên Tỉnh, Thiên Trụ, Đại Trữ, Đại chùy, Khúc Trì, Liệt khuyết, Hợp cốc, Giáp tích C4 - C7, A thị huyệt.

+ Châm bổ huyệt Huyền chung

+ Thời gian điện châm 30 phút/ ngày, liệu trình 15 ngày.

\subsubsection{Phương pháp đánh giá kêt quả}

- Đánh giá mức độ đau và hiệu suất giảm đau theo thang điểm VAS (Visual Analog Scale).
- Các chỉ tiêu được theo dõi trước điều trị $\left(D_{0}\right)$, sau 7 ngày $\left(D_{7}\right)$ và sau 15 ngày $\left(D_{15}\right)$.

2.3. Thời gian và địa điểm nghiên cứu: thời gian nghiên cứu từ 09/2020 - 08/2021, tại khoa Nội IV, khoa Châm cứu và Phục hồi chức năng - Bệnh viện Y học cổ truyền Bộ Công an.

2.4. Phương pháp xử lý số liệu: số liệu trong nghiên cứu được phân tích, xử lý theo phương pháp thống kề y sinh học, sử dụng phần mềm SPSS 20.0.

\section{KẾT QUẢ NGHIÊN CỨU}

\section{1. Đặc điểm lâm sàng}

Bảng 0.9. Đặc điểm lâm sàng của đôî tượng nghiên cứu

\begin{tabular}{|c|c|c|c|c|}
\hline & $\begin{array}{c}\text { Nhóm } \\
\text { nghiên cứu } \\
(\mathrm{n}=\mathbf{3 0})\end{array}$ & $\begin{array}{c}\text { Nhóm } \\
\text { chứng } \\
(n=30)\end{array}$ & PNC-C \\
\hline \multicolumn{2}{|c|}{$\begin{array}{c}\text { Độ tuối trung } \\
\text { bình }\end{array}$} & $\begin{array}{c}53,47 \pm \\
9,02\end{array}$ & $\begin{array}{c}53,23 \pm \\
9,93\end{array}$ & \multirow{9}{*}{$\begin{array}{l}\mathrm{p}> \\
0,05\end{array}$} \\
\hline \multirow{2}{*}{ Giới } & $\operatorname{Nam}(\%)$ & 23,3 & 30,0 & \\
\hline & Nữ (\%) & 76,7 & 70,0 & \\
\hline \multirow{3}{*}{$\begin{array}{l}\text { Thời } \\
\text { giann } \\
\text { mắc } \\
\text { bệnh }\end{array}$} & $<$ 1tháng & 23,3 & 23,3 & \\
\hline & 1-3 tháng & 36,7 & 26,7 & \\
\hline & > 3tháng & 40,0 & 50,0 & \\
\hline \multirow{3}{*}{$\begin{array}{l}\text { Vị trí } \\
\text { đau }\end{array}$} & $\begin{array}{l}\text { Lan vùng } \\
\text { chẩm }\end{array}$ & 67,4 & 63,3 & \\
\hline & $\begin{array}{l}\text { Lan cánh } \\
\text { tay }\end{array}$ & 53,3 & 46,7 & \\
\hline & $\begin{array}{c}\text { Cột sống } \\
\text { cổ }\end{array}$ & 100 & 100 & \\
\hline \multicolumn{2}{|c|}{ VAS trung bình } & $5,5 \pm 1,38$ & $5,3 \pm 1,53$ & $>0,05$ \\
\hline
\end{tabular}

Tuổi, giới, thời gian mắc bênh, vị trí đau, mức độ đau theo thang điểm VAS trước điều trị ở 2 nhóm không có sự khác biệt với $p>0,05$.

\subsection{Kết quả điêu trị}

\subsubsection{Hiêu quả giảm đau theo thang điểm VAS}

\section{Bảng 0.2. Phân bố bệnh nhân theo mức độ đau VAS sau điều trị}

\begin{tabular}{|c|c|c|c|c|c|c|c|c|c|c|c|c|}
\hline \multirow{3}{*}{ Mức độ VAS } & \multicolumn{6}{|c|}{ Nhóm nghiên cứu $(n=30)$} & \multicolumn{6}{|c|}{ Nhóm chứng $(n=30)$} \\
\hline & & \multicolumn{2}{|c|}{$D_{7}$} & \multicolumn{2}{|c|}{$\mathrm{D}_{15}$} & \multicolumn{2}{|c|}{ Do } & \multicolumn{2}{|c|}{$D_{7}$} & \multicolumn{2}{|c|}{$D_{15}$} \\
\hline & $\mathbf{n}$ & $\%$ & $\mathbf{n}$ & $\%$ & $\mathbf{n}$ & $\%$ & $\mathbf{n}$ & $\%$ & $\mathbf{n}$ & $\%$ & $\mathbf{n}$ & $\%$ \\
\hline Không đau & & & & & 10 & 33,3 & & & & & 2 & 6,7 \\
\hline Đau nhe & & & 7 & 23,3 & 19 & 63,3 & & & 9 & 30,0 & 22 & 73,3 \\
\hline Đau vừa & 6 & 20,0 & 18 & 60,0 & 1 & 3,3 & 10 & 33,3 & 13 & 43,3 & 6 & 20,0 \\
\hline Đau nặng & 16 & 53,3 & 5 & 16,7 & & & 13 & 43,3 & 8 & 26,7 & & \\
\hline Đau rất nặng & 8 & 26,7 & & & & & 7 & 23,3 & & & & \\
\hline Tống & 30 & 100 & 30 & 100 & 30 & 100 & 30 & 100 & 30 & 100 & 30 & 100 \\
\hline$p$ & & & & , ,05 & & & & & & 05 & & \\
\hline PD7 (NC-C) & & & & & & $p>$ & 05 & & & & & \\
\hline PD15 (NC-C) & & & & & & $p$ & 05 & & & & & \\
\hline
\end{tabular}

Sau điêu trị, mức độ đau của từng nhóm so với trước điều trị giảm có ý nghĩa thống kê với $\mathrm{p}<$ 0,05 . Mức độ giảm đau tại ngày thứ 7 sau điều trị khác biệt không có ý nghĩa thống kê giữa hai nhóm $(p>0,05)$. Tuy nhiên, tại thời điểm 15 ngày sau điều trị, mức độ giảm đau của nhóm nghiên cứu tốt hơn nhóm chứng $(p<0,05)$. 


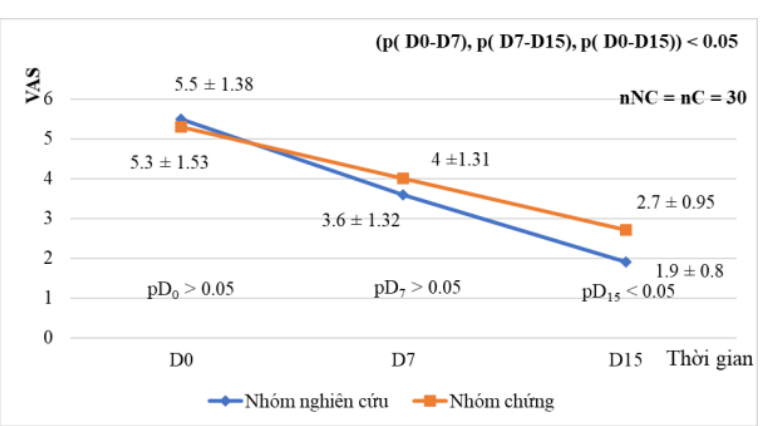

Biểu đồ 0.1. Cải thiện mức độ đau theo thang điểm VAS tai các thời điểm

Sau 15 ngày điều trị, mức độ đau theo thang điểm VAS của hai nhóm đều giảm có ý nghĩa thống kê so với trước điều trị với $p<0,05$. Mức độ giảm điểm VAS ở nhóm nghiên cứu cao hơn nhóm chứng $(p<0,05)$.

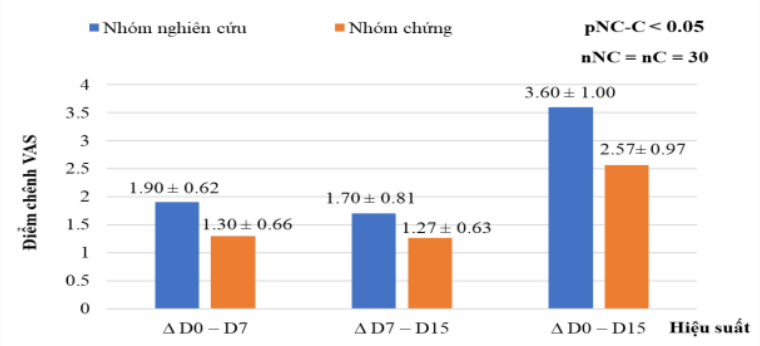

pD0-D7, pD7-D15, pD0- D15 $<0.05$

\section{Biểu đồ 0.2. Hiệu suât giảm điểm VAS theo} thời gian

Hiệu suất giảm điểm đau VAS đều giảm ở cả 2 nhóm theo thời gian điều trị. Mức độ giảm ở nhóm nghiên cứu cao hơn so với nhóm chứng ( $\mathrm{p}$ $<0,05)$.

\section{BÀN LUÂ̂N}

Trong THCSC vị trí đau thường gặp trên lâm sàng là đau vùng cổ gáy, lan lên chẩm, lan xuống cánh tay. Đây là triệu chứng gây khó chịu khiến bênh nhân phải đi khám và điều trí. Nguyên nhân đau cổ gáy là do các gai xương làm hẹp lỗ gian đốt sống, kích thích các rễ thần kinh hoặc receptor nhận cảm giác đau ở gân, cơ, dây chẳng và tổ chức cạnh khớp gây đau. Triệu chứng đau lan xuống cánh tay là khi các gai xương chèn ép vào rễ thần kinh trong lỗ liên hợp, gây kích thích rễ, kèm theo phản ứng viêm xung quanh rễ và tổn thương mạch máu gây phù nề, thiếu máu thứ phát. Khi THCSC ở những đốt sống cổ cao, làm hẹp lỗ tiếp hợp gây chèn ép vào các rễ thần kinh cảm giác chi phối vùng đỉnh chẩm (chẩm lớn và chẩm bé) và động mạch đốt sống làm giảm lưu lượng tuần hoàn của động mạch đốt sống này gây nên cảm giác đau lan lên vùng chẩm [6], [7].
Sau 15 ngày điều trị, điểm VAS trung bình đều giảm ở cả 2 nhóm. Ớ nhóm nghiên giảm nhiều hơn nhóm chứng (Nhóm nghiên cứu còn $1,9 \pm 0,8$ điểm; Nhóm chứng còn 2,7 $\pm 0,95$ điểm) với $\mathrm{p}<0,05$. Hiệu suất giảm điểm đau VAS ở nhóm nghiên cứu cao hơn so với nhóm chứng (Nhóm nghiên cứu: 3,6 $\pm 1,0$; Nhóm chứng: $2,7 \pm 0,97)$ với $p<0,05$. Kết quả này tương đồng với Mai Trung Dũng (2014) sau điều trị 100\% số bệnh nhân có mức độ đau nhe và đau rất nhe [4]. Ngyễn Thị Ngọc Ánh (2018) điểm VAS giảm từ $5,6 \pm 1,4$ xuống $1,67 \pm 1,86$ [1].

Theo YHCT, điên châm thông qua tác động vào huyệt vị và kinh lạc có tác dụng điều hoà khí huyết, thông kinh mạch, từ đó có tác dụng giảm đau. Theo YHHĐ, châm cứu có tác dụng giảm đau theo cơ chế thần kinh và thể dịch, thông qua khởi động cung phản xạ tại chỗ, tiết đoạn và thần kinh. Đồng thời châm cứu cũng giải phóng các chất trung gian hoá học như opioid nội sinh [5]. Trong nghiên cứu sử dụng cách chọn huyệt theo cục bộ thủ huyệt (Phong trì, Kiên ngung, Kiên tỉnh, Thiên trụ, Đại trữ, Đại chuỷ, Giáp tích và $A$ thị huyệt); theo tuần kinh thủ huyệt (Khúc trì, Liệt Khuyết); theo phối huyệt đặc biệt, trong lục tổng huyệt (Hợp cốc là huyệt chủ vùng đâu mặt cố, Liệt khuyết là huyệt chủ vùng cổ gáy, Huyền chung là huyệt hội của tuỷ xương trong bát hội huyệt). Chính việc phối ngũ các huyệt phù hợp nên hiệu quả giảm đau rất tốt trên bênh nhân đau do hội chứng cổ vai tay do thoái hoá cột sống cổ. Bên cạnh đó, nhóm nghiên cứu kết hợp đắp Parafin vào vùng cổ vai. Parafin thuộc nhiệt nóng trị liệu nông có tác dụng làm giã̃n mạch tại chỗ hoặc toàn thân thông qua cơ chế phản xa giúp làm giảm quá trình viêm, tiết dịch, thúc đẩy quá trình lành vết thương, làm tăng dinh dưỡng tại chỗ, tăng ngưỡng kích thích thần kinh và tăng chuyển hoá, ngăn ngừa thoái hoá sợi cớ, tăng phát triển colagen trong tổ chức liên kết, từ đó góp phần làm giảm đau, giãn cơ vùng vai gáy [2]. Vì vậy, khi kết hợp giữa điện châm và đắp Parafin trong điều trị hội chứng cổ vai tay do THCSC hiệu quả giảm đau tốt hơn nhóm chì sử dụng châm cứu đơn thuần.

\section{KẾT LUÂNN}

Điện châm kết hợp đắp Parafin có tác dụng giảm đau trên bệnh nhân hội chứng cổ vai tay do THCSC. Mức độ đau theo thang điểm VAS giảm từ $5,5 \pm 1,38$ điểm xuống $1,9 \pm 0,8$ điểm ở nhóm nghiên cứu, cao hơn nhóm chứng $(5,3 \pm$ 1,53 điểm xuống $2,7 \pm 0,95$ điểm). Sự khác biệt có ý nghĩa thông kê với $p<0,05$ 
TÀI LIỆ THAM KHẢO

1. Nguyễ̃n Thị Ngọc Ánh, Nguyễn Thị Kim Liên, Nguyển Thị Thu Hà (2018). Tác dụng giảm đau và cải thiện tầm vận động cột sống cổ của điện châm kết hợp bài tập cột sống cổ trên bệnh nhẩn đau vai gáy do thoái hoá cột sống cổ. Tạp chí Y học Việt Nam, 87-91.

2. Bồ mốn phục hôi chức năng - Trường Đại hoc Y Hà Nô̂i (2017). Phục hồi chức năng (Dùng cho bác sĩ định hướng chuyên khoa). Nhà xuất bản Y hoc, 42-45.

3. Bộ y tế (2008), Quy trình kỹ thuật Y học cổ truyển, Quy trình 46 (Điện châm điều trị hội chứng vai gáy).
4. Mai Trung Dũng (2014). Đánh giá kết quả điều tri kết hợp tâp con lăn Doctor100 trên bệnh nhân hối chứng cổ vai cánh tay do thoái hóa cột sống cổ. Luận văn Bác sĩ chuyên khoa II, Trưởng Đại hoc $Y$ Ḣ̀ Nô̂i, 94.

5. Nguyến Nhược Kim và Trân Quang Đạt (2008). Châm cứu và các phương pháp chửa bênh không dùng thuốc. Nhà xuất bản $Y$ hoc, Hà Nội, 37, 77, 114-115, 136-158,166-174, 223-225.

6. Nguyến Thị Ngọc Lan (2012). Bệnh học cơ xương khớp nội khoa. Nhà xuất bản Y học, Hà Nội, 138-151.

7. Childress M.A. và Becker B.A. Nonoperative Management of Cervical Radiculopathy. Am Fam Physician. 2016;93(9):746-754.

\section{SO SÁNH CHỈ SỐ CORNELLVÀ SOKOLOW - LYON TRÊN ĐIỀN TÂM ĐỒ TRONG CHẨN ĐOÁN PHÌ ĐẠI THẤT TRÁI Ở BÊNH NHÂN TĂNG HUYẾT ÁP TIÊN PHÁT}

\section{TÓM TẮT}

Mục tiêu: Khảo sát giá trị chẩn đoán phì đại thất trái (PĐTT) của chỉ số Cornell và Sokolow- Lyon trên điện tâm đồ (ĐTĐ) ở bệnh nhân tăng huyết áp (THA). Phương pháp nghiên cứu: Mổ tả cắt ngang. Đối

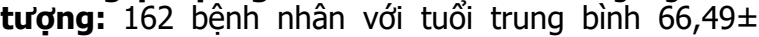
10,63 năm (nam giới chiếm 45,6\%) có THA được khảo sát PĐTT qua chỉ số Cornell và Sokolow-Lyontại Viện Tim Mạch Bach Mai thời gian từ 8/2020 đến 8/2021. Tiêu chuẩn phì đại thất trái được xác định qua siêu âm tim với khối lượng cơ thất trái $116 \mathrm{~g} / \mathrm{m}^{2}$ với nam và $96 \mathrm{~g} / \mathrm{m}^{2}$ với nữ. Kết quả: Diện tích của chỉ số điện thế Cornell so ba chỉ số điện thế Sokolow-Lyon, Sok P (Sokolow Lyon tích hợp) và Cornell $\mathrm{P}$ (Cornell tích hợp), khi chẩn đoán PĐTT có đối chiếu LVM/BSA: $(0,617$ so với 0,607 và $0,527,0,546$ ở nam; 0,555 so với 0,538 và $0,531,0,525$ ở nữ) với $p=N S$. Kết luận. Chỉ số điện thế Cornell có giá trị chẩn đoán PĐTT tương đương chỉ số Sokolow Lyon.

Tư khóa. Chỉ số Cornell và Sokolow Lyon, phì đại thất trái.

\section{SUMMARY}

\section{A COMPARISON OF CORNELL AND SOKOLOW - LYON ELECTROCARDIOGRAPHIC FOR LEFT VENTRICULAR HYPERTROPHY IN PATIENTS WITH HYPERTENSION}

Objectives. Survey the diagnostic value of left

\footnotetext{
${ }^{1}$ Bệnh viện Tỉnh Sơn La

²Bênh viện Tim Hà Nội

${ }^{3}$ Viện Tim mach ViêT Nam-Bênh viện Bạch Mai

Chịu trách nhiệm chính: Tạ Vắn Huyện

Email: hoanghuyenyk88@gmail.com

Ngày nhận bài: 6.8.2021

Ngày phản biên khoa hoc: 4.10 .2021

Ngày duyệt bài: 15.10.2021
}

ventricular hypertrophy of theCornell and SokolowLyon index on the electrocardiogram in hypertension patients. Methods. Cross-sectional descriptive study.

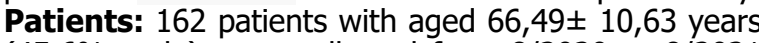
(45,6\% male) were collected from 8/2020 to 8/2021 at Vietnam National Heart Institute, the echocardiographic LVH which was defined as LVM index $\geq 116 \mathrm{~g} / \mathrm{m}^{2}$ in male patients and $\geq 96 \mathrm{~g} / \mathrm{m}^{2}$ in female patients. Results. The measured area under the curve of each area index of the Cornell voltage index is equivalent tothe three Sokolow-Lyon, Sok P (Sokolow Lyon Product) and Cornell P (Cornell Product) voltage indexes when diagnosing $\mathrm{LVH}$ with LVM/BSA comparison: 0.617 versus (vs) 0.607 and 0.527 vs 0.546 in male patients; 0.555 vs 0.538 and 0.531 vs 0.525 in female patientswith $p=N S$. Conclusions. The Cornell ECG criteria for the echocardiographic LVH had equivalent to SokolowLyon index in hypertension patients.

Key word. Cornell and Sokolow Lyon index, left ventricular hypertrophy.

\section{I. ĐẶT VẤN ĐỀ}

Phì đại thất trái (PĐTT) là một biến chứng của THA, cũng là yếu tố nguy cơ của các bệnh lý tim mạch khác. Nó làm tăng nguy cơ bệnh mạch vành lên 3 lần, suy tim lên hơn 13 lần, tai biến mạch máu não lên khoảng 6 lần và các nguy cơ động mạch ngoại biên, đột tử cũng 4-5 lần so với người không bị PĐTT. Để chẩn đoán PĐTT trên ĐTĐ có rất nhiêu chỉ số điện thế: Cornell, Sokolow Lyon, Norman,... nhìn chung chỉ đạt được độ đặc hiệu cao, còn độ nhạy thì lại rất thấp [1-3]. Đã có nhiêu nghiên cứu trên thế giới và Việt Nam nói về giá trị chẩn đoán PĐTT của các tiêu chí trên ĐTĐ nhưng so sánh riêng giữa tiêu chí điện thế Cornell và Sokolow Lyon thì 
chưa có nhiều. Chúng tôi thực hiện nghiên cứu này nhằm khẳng định giá trị của chỉ số điện thếCornell và Sokolow Lyon trong chẩn đoán PĐTT khi áp dụng trên bệnh nhân THA ở Việt Nam.

\section{II. ĐỐI TƯợNG VÀ PHƯƠ'NG PHÁP NGHIÊN CỨU}

Đối tượng nghiên cứu: Các bệnh nhân THA tới khám và điều trị tại Viện Tim mạch Việt Nam trong thời gian từ tháng 8/2020 đến 8/2021.

Tiêu chuẩn chọn bệnh nhân: Các bệnh nhân đến khám và điều trị tại viện Tim mạch ,được chẩn đoán THA theo tiêu chuẩn 2018 [4], được làm đồng thời cả SAT và ĐTĐ. Các bệnh nhẩn này đồng ý tham gia nghiên cứu.

Tiêu chuẩn loại trừ: $\mathrm{BN}$ tăng huyết áp thứ phát. Bệnh van tim: hẹp van tim nhe đến nặng, hở van vừa và nặng. Rối loạn nhịp tim, những trường hợp không phải nhịp xoang. Đái tháo đường.

Thiết kế nghiên cứu: Cắt ngang, mô tả.

Phương pháp chọn mẫu: Thuận tiên,tất cả bênh nhân thỏa mãn những tiêu chuẩn chọn mẫu sẽ đưa vào nghiên cứu theo trình tự thời gian.

Thu thập số liệu: Những biến số về tuổi, giới, tiền sử bệnh thu thập qua bệnh án. Chiều cao, cân nặng được đo trực tiếp bằng thước và cân bàn. Bệnh nhân được đo huyết áp được chẩn đoán THA sau đó sẽ் làm ĐTĐ: bằng máy đo 3 cần hiệu Schilercardiovit AI1, vận tốc máy đo là $25 \mathrm{~mm} / \mathrm{s}$, điện thế chuẩn là $10 \mathrm{~mm}$ bằng 1 milivolt. Bệnh nhân được nằm nghỉ 15 phút trước khi đo. Các chỉ số ĐTĐ khảo sát gồm: Sokolow-
Lyon: SV1 + RV5 hoặc RV6 $\geq 35 \mathrm{~mm}$, Cornell: $\mathrm{RaVL}+\mathrm{SV} 3 \geq 28 \mathrm{~mm}$ với nam ( $\geq 20 \mathrm{~mm}$ với nữ), Cornell tích hợp > $2440 \mathrm{~mm} * \mathrm{~ms}$, Sokolow Lyon tích hợp > 3340 mm*ms. Siêu âm tim: Đánh giá qua 5 mặt cắt lấy trung bình cộng của 5 mặt để tính khối lượng cơ thất trái được theo công thức Devereux (LVM = 1,04 x [ $\{$ LVDd + độ dày thành sau (LWd) + độ dày vách liên thất (IVSd) $\}^{3}$ LVIDd $\left.^{3}\right] \times 0,8+0,6$. Từ đó tính $L V M / B S A$ và LVM/chiều $\mathrm{caO}^{2,7}$. Ngưỡng phì đại: LVM/chiêu $\mathrm{cao}^{2,7} \geq 49 \mathrm{~g} / \mathrm{m}^{2,7}$ với nam, $\geq 45 \mathrm{~g} / \mathrm{m}^{2,7}$ với nữ). (LVMI: Khối lượng thất trái hiệu chỉnh theo chiều cao mũ $2,7\left(\mathrm{~g} / \mathrm{m}^{2,7}\right)$, theo Durex LVM/BSA $\geq$ $116 \mathrm{~g} / \mathrm{m}^{2}$ với nam và $\geq 96 \mathrm{~g} / \mathrm{m}^{2}$ với nữ $[5]$.

Xử lý thống kê. Sử dụng phần mềm SPSS 20.0. Tương quan được đánh giá bằng hệ số Pearson (R). Tính các giá trị của chỉ số ĐTĐ gồm: độ nhạy, độ đặc hiệu, giá trị tiên đoán dương, giá trị tiên đoán âm và độ chính xác. So sánh chỉ số Cornell với các chỉ số cùng khảo sát. So sánh các độ nhạy ở cùng một độ đặc hiệu $90 \%, 95 \%$ và $100 \%$. So sánh các đường cong ROC qua các diện tích nằm dưới các đường cong này.

\section{KẾT QUẢ NGHIÊN CứU}

Từ tháng 8/2020 đến 8/2021 chúng tôi thu thập được 162 bệnh nhân gồm 78 nam và 84 nữ, tuổi: cao nhất là 90 tuổi, thấp nhất là 27 tuổi, trung bình là $66,49 \pm 10,63$ tuổi. Giới: nam chiếm $48 \%$ và nữ chiếm $52 \%$.

Bảng 1. Đặc điểm nhân trắc học

\begin{tabular}{|c|c|c|c|c|}
\hline & Nam (n = 78) & Nữ (n = 84) & Tống (n=162) & p \\
\hline Tuối (năm) & $64,81 \pm 12,30$ & $68,05 \pm 8,59$ & $66,49 \pm 10,63$ & 0,052 \\
\hline Chiêu cao (cm) & $164,46 \pm 6,30$ & $154,06 \pm 5,12$ & $159,07 \pm 7,73$ & 0,000 \\
\hline Cân nặng (kg) & $62,08 \pm 9,83$ & $53,43 \pm 7,82$ & $57,59 \pm 9,82$ & 0,000 \\
\hline BMI (kg/m²) & $22.89 \pm 2,91$ & $22,48 \pm 2,88$ & $22,68 \pm 2,9$ & 0,364 \\
\hline Nhẹ cân (n,\%) & $8(10,3)$ & $6(7,1)$ & $14(8,6)$ & \multirow{2}{*}{0,828} \\
\hline Bình thường (n\%) & $35(44,9)$ & $43(51,2)$ & $78(48,1)$ & \\
\hline Thửa cân (n\%) & $30(38,5)$ & $30(35,7)$ & $60(37,0)$ & \\
\hline Béo phì (\%) & $5(6,4)$ & $5(6,0)$ & $10(6,2)$ & \\
\hline
\end{tabular}

Bảng 2: Tỷ lệ phi đại thất trái trên ĐTĐ:

\begin{tabular}{|c|c|c|c|}
\hline & Nam & Nữ & Chung \\
\hline Cor V & $3,8 \%$ & $6,0 \%$ & $4,9 \%$ \\
\hline Cor P & $3,81 \%$ & $1,2 \%$ & $2,5 \%$ \\
\hline Sok V & $10,1 \%$ & $8,3 \%$ & $9,2 \%$ \\
\hline Sok P & $5,1 \%$ & $2,4 \%$ & $3,7 \%$ \\
\hline
\end{tabular}

Bảng 3. Mối tương quan giữa bốn tiêu chí điện tâm đồ và hai loại chỉ số khối tâm thất trái ở nam giới

\begin{tabular}{|c|c|c|c|c|}
\hline \multirow{2}{*}{} & \multicolumn{2}{|c|}{ LVMI/BSA } & \multicolumn{2}{c|}{ LVMI/chî̂u cao $^{\mathbf{2 , 7}}$} \\
\cline { 2 - 5 } & $\mathbf{r}$ & $\mathbf{p}$ & $\mathbf{r}$ & $\mathbf{p}$ \\
\hline Sokolow-Lyon(mv) & 0,1758 & 0,1238 & 0,1892 & 0,0971 \\
\hline Sokolow-Lyon tích hợp (mm.ms) & 0,1166 & 0,3094 & 0,1229 & 0,2837 \\
\hline Cornell(mm) & 0,1973 & 0,0233 & 0,2130 & 0,0211 \\
\hline Cornell tích hợp(mm.ms) & 0,1450 & 0,2054 & 0,1535 & 0,1796 \\
\hline
\end{tabular}




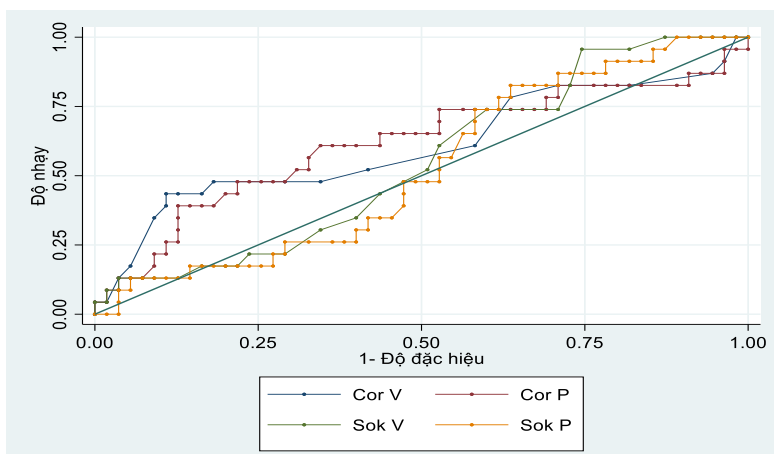

LVM/BSA

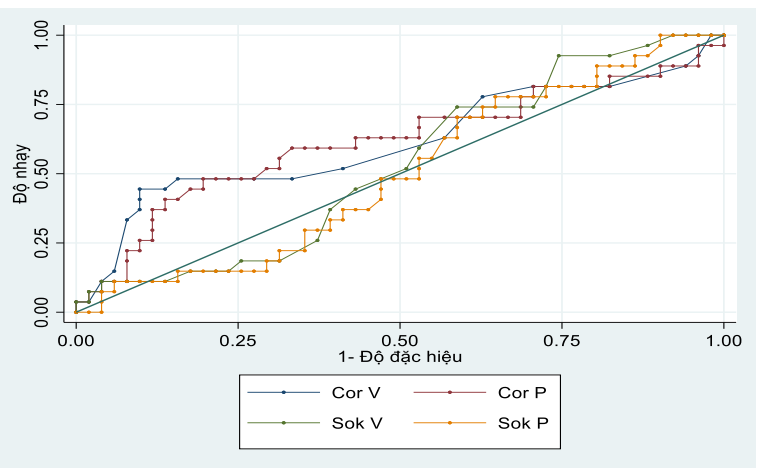

LVM/chiều cao ${ }^{2,7}$

Biểu đồ 1. Đồ thị đường cong ROC ở giới nam

\begin{tabular}{|c|c|c|c|c|}
\hline & \multicolumn{4}{|c|}{ P so sánh bắt că̆p giữa các AUC } \\
\hline & Sok V & Cor V & Sok P & Cor P \\
\hline Sok V & - & - & - & - \\
\hline Cor V & 0,2542 & - & - & - \\
\hline Sok P & 0,4595 & 0,1296 & - & - \\
\hline Cor P & 0,2664 & 0,9353 & 0,0915 & - \\
\hline
\end{tabular}

Nhận xét: sự khác biệt về giá trị chấn đoán giữa các chỉ số điện tâm đồ là chưa có ý nghĩa thống kê (tất cả p so sánh đều > 0,05)

Bảng 4. Mối tương quan giữa bốn tiêu chí điện tâm đồ và hai loại chỉ số khối tâm thất trái ở nữ giới

\begin{tabular}{|c|c|c|c|c|}
\hline & \multicolumn{2}{|c|}{ LVMI/BSA } & \multicolumn{2}{|c|}{ LVMI/chiêu Cao $^{2,7}$} \\
\hline & $\mathbf{r}$ & $\mathbf{p}$ & $\mathbf{r}$ & $\mathbf{p}$ \\
\hline Sokolow-Lyon(mv) & 0,0422 & 0,7030 & 0,0515 & 0,6415 \\
\hline Sokolow-Lyon tích hợp (mm.ms) & 0,0003 & 0,9982 & 0,0213 & 0,8576 \\
\hline Cornell $(\mathrm{mv})$ & 0,1352 & 0,0220 & 0,1417 & 0,0190 \\
\hline Cornell tích hợp(mm.ms) & 0,0817 & 0,4599 & 0,0766 & 0,4886 \\
\hline
\end{tabular}

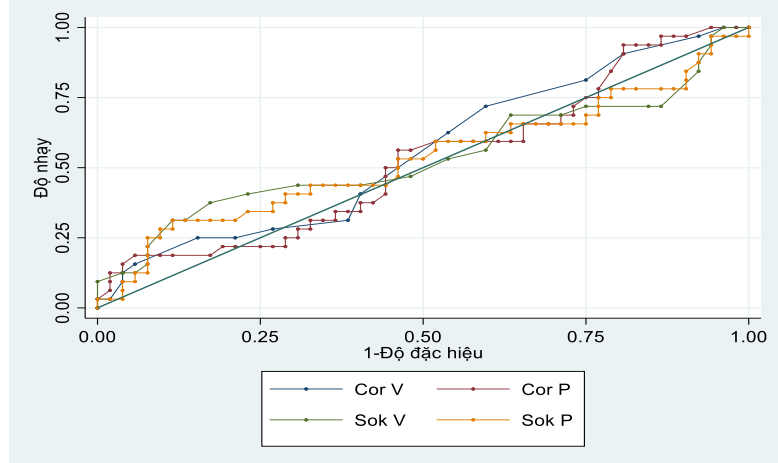

LVM/BSA

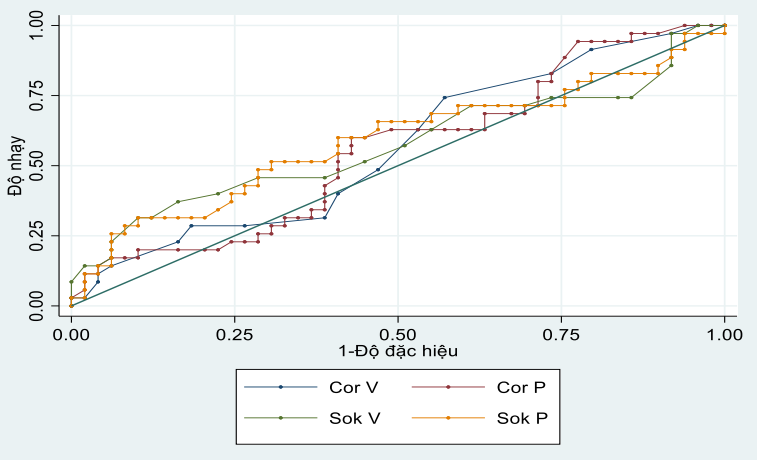

LVM/chiều $\mathrm{CaO}^{2,7}$

Biểu đồ 2. Đồ thị đường cong ROC ở giới nữ

\begin{tabular}{|c|c|c|c|c|}
\hline & \multicolumn{4}{|c|}{ P so sánh băt cặp giữa các AUC } \\
\hline & Sok V & Cor V & Sok P & Cor P \\
\hline Sok V & - & - & - & - \\
\hline Cor V & 0,8879 & - & - & - \\
\hline Sok P & 0,5162 & 0,7103 & - & - \\
\hline Cor P & 0,8136 & 0,8377 & 0,5834 & - \\
\hline
\end{tabular}

Nhận xét: sự khác biệt về giá trị chẩn đoán giữa các chỉ số điện tâm đồ là không có ý nghĩa thống kê $(p>0,05)$

\section{BÀN LUÂ̂N}

Phân bố tỉ lệ PĐTT theo giới: so sánh tỉ lệ PĐTT giữa hai giới có sự khác biệt không có ý nghĩa thống kê p>0,005

Tương quan giữa ĐTĐ và khối cơ thất trái trên siêu âm tim: Biểu đồ phân tán các phần tử tạo đám mây của 4 chỉ số đều có xu hướng là khối thất trái tăng thì các trị số ĐTÐ cũng tăng. Chúng tập trung có dạng đường 
thẳng tuyến tính thuận chiều. Biểu đồ đám mây của chỉ số Sokolow Lyon phân tán rộng nhất, cho giá trị hệ số tương quan thấp nhất( $R=0,17)$, còn biểu đồ đám mây của chỉ số Cornell thì tập trung quanh đường hồi quy, nên giá trị hể số tương quan cao hơn $(R=0.19)$ có ý nghĩa thống kê.

Độ nhay, độ đặc hiệu của 4 tiêu chí ĐTÐ: Chúng tôi thấy độ nhạy của 4 chỉ số ĐTĐ không khác nhau nhiêu và đều ở mức thấp, nhưng độ đặc hiệu của cả 4 tiêu chí ĐTĐ lại rất cao. Nhưng khi so sánh giá trị các chỉ số ĐTĐ ở cùng độ đặc hiệu: mặc dù độ nhạy của 4 chỉ số ĐTĐ là thấp nhưng khi so sánh chúng với nhau ở cùng độ đặc hiệu $90 \%, 95 \%$, và $100 \%$ thì chỉ số Cor V lại cho kểt quả cao hơn các chỉ số còn lại nhưng không có ý nghĩa thống kê.

So sánh đồ thị đường cong ROC của các chỉ số ĐTĐ: Chúng tôi thấy đường cong của chỉ số Cor $V$ nằm cao nhất ở cả 2 giới $(0,617$ ở nam; 0,525 ở nữ), đường cong của chỉ số Sok $V$ là thấp nhất, đặc biệt là ở giới nữ, mặc dù diện tích dưới đường cong của 4 tiêu chí ĐTÐ có khác nhau nhưng chưa có ý nghĩa thống kê và mức độ tương quan của từng chỉ số khi test chẩn đoán PĐTT lại ở mức yếu. Sau khi viết phương trình hồi quy cho các yếu tố ảnh hưởng đến chẩn đoán PĐTT chúng tôi thấy rằng: thời gian THA, chỉ số khối cơ thể (BMI), và có rối loạn lipid máu ảnh hưởng tới các chỉ số ĐTĐ, cụ thể là khi các yếu tố này tăng lên thì mức độ PĐTT cũng sẽ tăng lên.

\section{KẾT LUÂN}

Chỉ số điện thế Cornell có giá trị chẩn đoán PĐTT tương đương chỉ số Sokolow Lyon.

TÀI LIỆU THAM KHẢO
1. Sundström, J. et al. Echocardiographic and electrocardiographic diagnoses of left ventricular hypertrophy predict mortality independently of each other in a population of elderly men. Circulation 103, 2346-2351 (2001).

2. Molloy, T. J., Okin, P. M., Devereux, R. B. \& Kligfield, P. Electrocardiographic detection of left ventricular hypertrophy by the simple QRS voltageduration product. J. Am. Coll. Cardiol.20, 11801186 (1992).

3. Electrocardiographic detection of left ventricular hypertrophy using echocardiographic determination of left ventricular mass as the reference standard. Comparison of standard criteria, computer diagnosis and physician interpretation - PubMed. https:// pubmed.ncbi.nlm.nih.gov/6228571/.

4. Huỳnh Văn Minh, Phạm Gia Khải, Đặng Vặn Phước, Nguyến Lân Viête. Khuyến cáo về chẩn đoán và điêu trị THA 2018. Hội Tim mach hoc Viêt nam

5. Su, F.-Y. et al. A comparison of Cornell and Sokolow-Lyon electrocardiographic criteria for left ventricular hypertrophy in a military male population in Taiwan: the Cardiorespiratory fitness and HospItalization Events in armed Forces study. Cardiovasc. Diagn. Ther.7, 244-251 (2017).

6. Jj, N., Ta, A., Uf, N., C, N. \& Am, J. A metaanalytic evaluation of the diagnostic accuracy of the electrocardiographic Peguero-Lo Presti criterion for left ventricular hypertrophy. J. Clin. Hypertens. Greenwich Conn22, (2020).

7. Performance of Electrocardiographic Criteria for Echocardiographically Diagnosed Left Ventricular Hypertrophy in Chinese Hypertensive Patients - PubMed. https:// pubmed.ncbi.nlm.nih.gov/ 32484222/.

8. Sokolow, M. \& Lyon, T. P. The ventricular complex in left ventricular hypertrophy as obtained by unipolar precordial and limb leads. Am. Heart J.37, 161-186 (1949).

9. Giá trị của chỉ số norman trong chẩn đoán phì đại thất trái. https:// 123docz.net/ document/5950328-gia-tri-cua-chi-so-normantrong-chan-doan-phi-dai-that-trai.htm.

\title{
KẾT QUẢ ĐIỀU TRI HộI CHỨNG CHÈN ÉP KHOANG DƯỚI MỎM CÙNG VAI BẰNG TIÊM CORTICOSTEROID DƯớI HƯỚNG DẪN SIÊU ÂM
}

\author{
Hà Thanh Tâm ${ }^{1,2}$, Nguyễn Thị Ngọc Lan ${ }^{1}$, Phạm Hoài Thu ${ }^{1}$
}

\section{TÓM TẮT}

Muc tiêu nghiên cứu: Đánh giá kết quả điều trị hội chứng chèn khoang dưới mỏm cùng vai bằng tiêm

\footnotetext{
${ }^{1}$ Trường Đại học Y Hà Nội

²Bênh viện Trung ương Thái Nguyên

Chịu trách nhiệm chính: Phạm Hoài Thu

Email: phamhoaithu@hmu.edu.vn

Ngày nhận bài: 5.8.2021

Ngày phản biên khoa hoc: 4.10 .2021

Ngày duyệt bài: 15.10 .2021
}

corticosteroid dưới hướng dẫn của siêu âm và nhân xét một số tác dụng không mong muốn của liệu pháp.Đối tượng và phương pháp nghiên cứu: Nghiên cứu can thiêp theo dõi doc 29 bênh nhân với 34 khớp vai tổn thương, được chẩn đoán hội chứng chèn ép khoang dưới mỏm cùng vai và được tiêm 1 mũi Methylprednisolon acetat $40 \mathrm{mg}$ (Depomedrol 40 $\mathrm{mg}$ ) vào bao thanh dịch dưới mỏm cùng vai dướ hướng dẫn của siêu âm. Kết quả nghiên cứu: Sau 4 tuần điều trị có sự cải thiên về thang điểm VAS, EFA và góc dạng khớp vai. Đánh giá tại thời điểm trước tiêm và sau tiêm 4 tuần, VAS trung bình giảm từ 6,67 
\pm 0,84 điểm xuống 2,08 $\pm 1,31$ điểm. Điểm EFA và góc dạng khớp vai trung bình tăng tương ứng từ 9.73 \pm 1.54 điểm lên $15,30 \pm 1,64$ điểm và từ $63,08 \pm$ 14,30 độ lên 116,32 $\pm 16,84$ độ. Có sự khác biệt trước và sau điêu trịvới $p<0,05$. Tác dụng không mong muốn gặp trong quá trình điều trị là đau tăng tại vị trí tiêm. Có 12 khớp vai trong tổng số 34 khớp vai chiếm $35,29 \%$ đau tăng tại vị trí tiêm sau 24h. Không ghi nhận trường hợp nào có biểu hiện đau đầu, chóng mặt, sốc, nóng bừng mặt và nhiếm trùng tại chố sau tiêm. Kết luận: Điều trị hội chứng chèn ép khoang dưới mỏm cùng vai bằng phương pháp tiêm corticosteroid dưới hướng dẫn của siêu âm đạt kết quả tốt và là một liệu pháp an toàn, ít gặp các tác dụng không mong muốn.

Tư khóa: Hội chứng chèn ép khoang dưới mỏm cùng vai, tiêm corticosteroid, tiêm dưới hướng dẫn siêu âm

\section{SUMMARY \\ RESULTS OF TREATMENT OF SUBACROMIAL IMPINGEMENT SYNDROME WITH CORTICOSTEROID INJECTION UNDER ULTRASOUND GUIDANCE}

Objectives: To evaluate the results of treatment of subacromial impingement syndrome with corticosteroid injection under ultrasound guidance and to comment on some undesirable effects of the therapy. Methods: Interventional study longitudinal follow-up 29 patients with 34 injured shoulder joints, diagnosed with subacromial impingement syndrome and received 1 injection of Methylprednisolone acetate $40 \mathrm{mg}$ (Depomedrol 40mg) into the subacromial bursa under ultrasound guidance. Results: After 4 weeks of treatment, there was an improvement in VAS, EFA and shoulder angle. Assessed at the time of injection and 4 weeks after injection, the average VAS decreased from $6.67 \pm 0.84$ points to $2.08 \pm 1.31$ points. The mean EFA score and shoulder angle angle increased respectively from $9.73 \pm 1.54$ points to $15.30 \pm 1.64$ points and from $63.08 \pm 14.30$ degrees to $116.32 \pm$ 16.84 degrees. The difference before and after treatment was statistically significant with $p<0.05$. An undesirable effect encountered during treatment is increased pain at the injection site. There were 12 shoulder joints out of 34 shoulder joints, accounting for $35.29 \%$ of the increased pain at the injection site after 24 hours. There were no cases of headache, dizziness, shock, hot flushes and local infection after injection. Conclusions: Treatment of subacromial impingement syndrome by corticosteroid injection under ultrasound guidance achieved good results and was a safe therapy, with few undesirable effects.

Keywords; subacromial impingement syndrome, corticosteroid injection, ultrasound guided injection.

\section{I. ĐĂT VẤN ĐỀ}

Hội chứng chèn ép khoang dưới mỏm cùng vai (Subacromial impingement syndrome) là tình trạng cọ sát về mặt cơ học giữa các tổ chức phần mềm là gân chóp xoay, túi hoạt dịch dưới mỏm cùng vai với mấu động lớn xương cánh tay và mặt dưới của mỏm cùng vai và dây chằng cùng quạ ${ }^{1}$ Tình trạng diễn biếnkéo dài dẫn đến biên chứng đứt gẩn, rách chóp xoay. Biểu hiện bởi đau và hạn chế tầm vận động khớp vai, ảnh hưởng nhiều đến sinh hoạt và chất lượng cuộc sống của người bệnh. Điều trị hội chứng chèn ép khoang dưới mỏm cùng vai hiện nay thường là các thuốc NSAIDs đơn thuần hoăc kết hợp với vật lý trị liệu, xong thường tái phát. Việc đưa thuốc vào đúng vị trí bao thanh dịch dưới mỏm cùng vai dưới hướng dẫn siêu âm giúp làm tăng hiệu quả điều trị một cách rõ rệt ${ }^{2}$. Hiện nay, tại Việt Nam chưa có nghiên cứu nào về vấn đề này. Vì vậy chúng tôi tiến hành nghiên cứu đề tài này với 2 mục tiêu:

1. Đánh giá kêt quả điều trị hội chứng chèn ép khoang dưới mỏm cùng vai bằng tiêm corticosteroid dưới hướng dẫn của siêu âm

2. Nhận xét một số tác dụng không mong muốn của liệu pháp.

\section{II. ĐỐl TƯỢNG VÀ PHƯƠNG PHÁP NGHIÊN CỨU}

2.1. Đối tượng nghiên cứu: Gồm 29 bệnh nhân với 34 khớp vai tổn thương đến khám tại phòng khám Cơ xương khớp bệnh viện Bạch Mai từ tháng 1/2021 đến tháng 7/2021 được chẩn đoán hội chứng chèn ép khoang dưới mỏm cùng vaitheo tiêu chuẩn chẩn đoán Neer (1972) ${ }^{3}$ gồm các triệu chứng: Đau khớp vai $\geq 1$ tháng, VAS $\geq$ 4,có hạn chế vận động khớp vai, nghiệm pháp Neer và/hoặc Hawkins dương tính. Siêu âm khớp vai có viêm bao thanh dịch dưới mỏm cùng vai có thể kèm theo viêm gân chóp xoay, điển hình là viêm gân trên gai. Khoảng cách từ mỏm cùng vai đến chỏm xương cánh tay $\leq 6 \mathrm{~mm}$ được xác định trên Xquang chữ $Y$ (Outlet view)

Loại khỏi nghiên cứu các trường hợp có hội chứng nhiễm trùng toàn thân trên lầm sàng, bệnh nhân có các chống chỉ định của corticosteroid (tổn thương da tại vị trí tiêm, đái tháo đường, tăng huyết áp không được kiểm soát, dị ứng với corticoid...). Bệnh nhân đã tiêm corticosteroid tại khớp vai trong vòng 3 tháng.

2.2. Phương pháp nghiên cứu: Nghiên cứu tiến cứu, theo dõi dọc, có can thiệp. Cách chọn mẫu thuận tiện. Bệnh nhân được chẩn đoán có hội chứng chèn ép khoang dưới mỏm cùng vai được tiêm 1 mũi Methylprednisolone (Depomedrol $40 \mathrm{mg}$ ) vào bao thanh dịch dưới mỏm cùng vai dưới hướng dẫn siêu âm. Thủ thuật được tiến hành bởibác sỹ chuyên khoa Cơ xương khớp. Sử dụng máy siêu âm Medison Accuvix v 10.0, đầu dò Linear tần số 5-13 Mhz tại phòng khám Cơ xương khớp, BvBạch Mai. 
Đánh giá kết quả điều trị dựa trên thang điểm đau VAS, thang điểm EFA đánh giá mức độ hoạt đônng khớp và góc dạng khớp vai tại các thời điểm trước điều trị (TO), sau điều trị 1 tuần (T1), và sau điều trị 1 tháng (T4). Theo dõi tác dụng không mong muốn của liệu pháp được ghi nhận sau tiêm 30 phút, sau tiểm 1 ngày và tại các thời điểm đánh giá.

2.4. Sử lý số liệu theo phân mềm thống kê: SPSS 20.0

III. KẾT QUẢ NGHIÊN CỨU

3.1. Đặc điểm chungcủa bệnh nhân nghiên cứu

Bảng 1: Đặc điểm bệnh nhân nghiên cứu (n= 29 bệnh nhân)

\begin{tabular}{|c|c|c|c|c|}
\hline \multicolumn{3}{|c|}{$\begin{array}{c}\text { Đặc điểm bệnh nhân nghiên } \\
\text { cứu }\end{array}$} & \multicolumn{2}{|c|}{\begin{tabular}{c|c}
\multicolumn{2}{c}{$n=29$} \\
Số lượng \\
$\begin{array}{c}\text { Tỷ lệ } \\
\text { (n) }\end{array}$
\end{tabular}} \\
\hline \multirow{2}{*}{ Giới } & & Nam & 10 & 34,5 \\
\hline & & Nũ̃ & 19 & 65,5 \\
\hline \multicolumn{3}{|c|}{ Tuổi trung bình ( $34-70$ tuổi) } & \multicolumn{2}{|c|}{$56,76 \pm 8,50$} \\
\hline \multirow{4}{*}{$\begin{array}{l}\text { Nghề } \\
\text { nghiệp }\end{array}$} & \multirow{3}{*}{\multicolumn{2}{|c|}{\begin{tabular}{|c|} 
Giáo viên \\
Cán bộ, văn phòng \\
Nông dân, công \\
nhân lao đông năng \\
\end{tabular}}} & 3 & 10,3 \\
\hline & & & 6 & 20,7 \\
\hline & & & 16 & 55,2 \\
\hline & \multicolumn{2}{|c|}{ Nội trợ, bán hang } & 4 & 13,8 \\
\hline \multirow{5}{*}{$\begin{array}{l}\text { Hoạt động } \\
\text { thể lực, } \\
\text { thể dục } \\
\text { thể thao }\end{array}$} & \multirow{5}{*}{ Có } & Bơi lội & 2 & 6,9 \\
\hline & & Yoga & 5 & 17,3 \\
\hline & & $\begin{array}{l}\text { Bóng chuyền, } \\
\text { câuu lông }\end{array}$ & 3 & 10,3 \\
\hline & & Tống & 10 & 45,5 \\
\hline & & Không & 19 & 65,5 \\
\hline \multirow{3}{*}{$\begin{array}{l}\text { Thời gian } \\
\text { mắc bệnh }\end{array}$} & & Dưới 1 tháng & 5 & 17,2 \\
\hline & & $1-3$ tháng & 10 & 34,5 \\
\hline & & Trên 3 tháng & 14 & 48,3 \\
\hline \multirow{3}{*}{$\begin{array}{c}\text { Hoàn cảnh } \\
\text { xuất hiện }\end{array}$} & & Tự nhiên & 19 & 65,5 \\
\hline & Sau & mang vác nặng & 8 & 27,6 \\
\hline & & Chấn thương & 2 & 6,9 \\
\hline
\end{tabular}

Nhân xét: Đa số bênh nhân nghiên cứu là nữ giới $(65,5 \%)$ với tuổi trung bình là $56,76 \pm$
8,50. Nghề nghiệp nông dân, công nhân, người lao động nặng chiếm phần lớn với tỷ lệ $55,2 \%$. Có $10(45,5 \%)$ trường hợp có hoat động thể lực, thể dục thể thao kèm theo. Tỷ lệ bệnh nhân có thời gian mắc bệnh trên 3 tháng cao nhất chiếm 48,3\%. Hoàn cảnh xuất hiện chủ yếu là tự nhiên chiếm $65,5 \%$.

Bảng 2: Vị trí tổn thương ( $n=29$ bênh nhân) \begin{tabular}{|c|c|c|}
\hline Vị trí tổn thương & Số lượng (n) & Tỷ lê \% \\
\hline
\end{tabular}

\begin{tabular}{|c|c|c|}
\hline Vai trái & 9 & $31,0 \%$ \\
\hline Vai phải & 15 & $51,7 \%$ \\
\hline Hai vai & 5 & $17,2 \%$ \\
\hline
\end{tabular}

Nhân xét: 29 bênh nhân với 34 khớp vai bi tổn thương. Trong đó, tổn thương vai phải chiếm $51,7 \%$, vai trái $31,0 \%$ và $17,2 \%$ tổn thương cả 2 vai.

3.2. Đánh giá kết quả điêu trị hội chứng chèn ép khoang dưới mỏm cùng vai bằng phương pháp tiêm corticoid dưới hướng dẫn của siêu âm

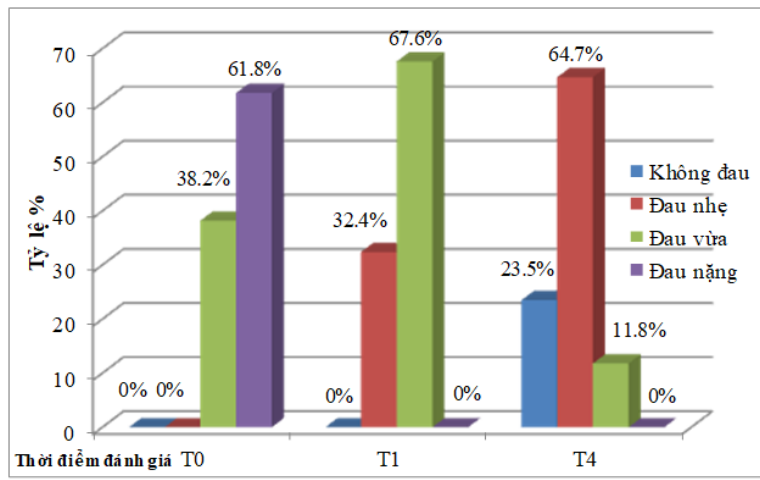

Biểu đồ 1: Kêt quả điều tri qua thang điểm VAS ( $n=34$ khớp vai)

Nhận xét: $100 \%$ bệnh nhân tại thời điểm T0 trước điều trị đều có mức độ đau theo thang điểm VAS ở mức đau vừa và nặng. Mức độ đau được cải thiện ngay sau 1 tuần điều trị và giảm dần ở tuần thứ 4 , tại thời điểm sau điều trị 1 tuần đã không còn bệnh nhân nào đau nặng, có 8 khớp vai $(23,5 \%)$ hoàn toàn hết đau sau 4 tuần điều trị.

Bảng 3: Kết quả điều trị theo thang điểm VAS, EFA và góc dạng khớp vai ( $n=34$ khớp vai)

\begin{tabular}{|c|c|c|c|c|}
\hline & T0 & T1 & T4 & T4-T0 \\
\hline VAS & $6,67 \pm 0,84$ & $4,32 \pm 1,25$ & $2,08 \pm 1,31$ & $-4,58 \pm 1,10$ \\
\hline EFA & $9,73 \pm 1,54$ & $12,62 \pm 1,23$ & $15,30 \pm 1,64$ & $5,55 \pm 2,07$ \\
\hline Góc dạng khớp vai & $63,08 \pm 14,30$ & $84,55 \pm 12,69$ & $116,32 \pm 16,84$ & $53,23 \pm 21,49$ \\
\hline \multicolumn{4}{|r|}{$\mathrm{p}<0,05$} \\
\hline
\end{tabular}

Nhận xét: Có sự cải thiện thang điểm VAS, EFA và góc vận dạng khớp vai sau 1 tuần điều trị và được duy trì đến thời điểm sau 4 tuần. Sự cải thiện có ý nghĩa thống kê $p<0,05$

\subsection{Tác dụng không mong muốn của liệu pháp}

3.3.1. Tại thời điểm làm thủ thuật 
Bảng 4: Chi số mạch, huyết áp trước và sau tiêm ( $n=29$ bệnh nhân)

\begin{tabular}{|c|c|c|c|c|c|c|}
\hline $\begin{array}{c}\text { Chỉ số } \\
\text { theo } \\
\text { dõi }\end{array}$ & $\begin{array}{c}\text { Mạch trước } \\
\text { tiêm }\end{array}$ & $\begin{array}{c}\text { Mạch sau } \\
\text { tiêm }\end{array}$ & $\begin{array}{c}\text { Huyết áp } \\
\text { Tr trước } \\
\text { tiêm }\end{array}$ & $\begin{array}{c}\text { Huyết áp } \\
\text { Tr sau } \\
\text { tiêm }\end{array}$ & $\begin{array}{c}\text { Huyết áp } \\
\text { Trr trước } \\
\text { tiêm }\end{array}$ & $\begin{array}{c}\text { Huyết áp } \\
\text { Trr sau } \\
\text { tiêm }\end{array}$ \\
\hline$X \pm S D$ & $77,58 \pm 5,56$ & $80,03 \pm 4,44$ & $117,37 \pm 9,05$ & $123,00 \pm 9,80$ & $74,24 \pm 6,59$ & $76,82 \pm 9,18$ \\
\hline$p$ & \multicolumn{2}{|c|}{$p<0,05$} & \multicolumn{2}{|c|}{$p<0,05$} & $p>0,05$ \\
\hline
\end{tabular}

Nhân xét: Tại thời điếm trước và sau tiêm 30 phút có sự thay đối về mạch và huyết áp tâm thu $(\mathrm{p}<0,05)$

Bảng 5: Tác dụng không mong muốn tại thời điểm làm thủ thuật ( $n=29$ bệnh nhân)

\begin{tabular}{|c|c|c|}
\hline $\begin{array}{c}\text { Tác dụng khống } \\
\text { mong muốn }\end{array}$ & $\begin{array}{c}\text { Số lượng } \\
\text { (n) }\end{array}$ & $\begin{array}{c}\text { Tỷ lệ } \\
(\mathbf{\%})\end{array}$ \\
\hline $\begin{array}{c}\text { Sốc phản vệ } \\
\text { Nóng bừng, đaù đầu, } \\
\text { chóng mặt }\end{array}$ & 0 & 0 \\
\hline Cường phể vị & 0 & 0 \\
\hline Chảy máu tại chồ & 0 & 0 \\
\hline
\end{tabular}

Nhận xét: Tại thời điểm làm thủ thuật không có bệnh nhân nào có biểu hiện toàn thân như sốc, nóng bừng, đau đâu, chóng mặt, cũng không có bệnh nhân nào bị chảy máu tại chố tiêm.

3.3.2. Tại thời điểm sau tiêm 1 ngày đến 4 tuần

Bảng 6: Tác dụng không mong muốn của liệu pháp

tại thời điểm sau tiêm 1 ngày đến 4 tuần $(n=34$ khớp vai)

\begin{tabular}{|c|c|c|c|}
\hline Vị trí & $\begin{array}{c}\text { Tác dụng } \\
\text { không mong muốn }\end{array}$ & $\begin{array}{c}\text { Số lượng } \\
\text { (n) }\end{array}$ & $\begin{array}{c}\text { Tỷ lệ } \\
(\mathbf{\%})\end{array}$ \\
\hline \multirow{4}{*}{ Tại chỗ } & $\begin{array}{c}\text { Đau tăng tại vị trí } \\
\text { tiêm }\end{array}$ & 12 & 35,29 \\
\cline { 2 - 4 } & Nhiêm trùng & 0 & 0 \\
\cline { 2 - 4 } & $\begin{array}{c}\text { Teo da, bạch biến } \\
\text { trên da }\end{array}$ & 0 & 0 \\
\hline
\end{tabular}

Nhận xét: Sau tiêm có 12 khớp vai $(35,29 \%)$ đau tăng sau tiêm 1 ngày. Không có trường hợp nào nhiễm trùng, teo da, bạch biến trên da.

\section{BÀN LUẬN}

4.1. Kết quả nghiên cứu. Hội chứng chèn ép khoang dưới mỏm cùng vai là hội chứng hay gặp trên lâm sàng. Theo nghiên cứu của Dhillon năm 2019, đã chỉ ra rằng hội chứng này chiếm khoảng $48 \%$ các trường hợp đau vai, các biểu hiện đau mạn tính với thời gian bị bệnh $\geq 3$ tháng ${ }^{4}$. Nghiên cứu của chúng tôitại bảng 1 chothấy phần lớn bệnh gặp ở nữ giới, với tỷ lệ $65,5 \%$, độ tuổi trung bình trong nghiên cứu là $56,76 \pm 8,50$. Năm 2020, nghiên cứu củaNajibeh Akbari khi thực hiện tiêm corticoid điêu trị hội chứng chèn ép khoang dưới mỏm cùng vai cho 28 bệnh nhân cũng nhận thấy điều tương tự với tỷ lệ nữ nhiều hơn nam. Cụ thể trong nghiên cứu này nữ chiếm $60,71 \%$ và nam là $39,29 \%$ với độ tuổi trung bình là $42,5^{2}$

Một số yễu tố khởi phát đau ở nhóm bệnh nhân có hội chứng chèn ép khoang dưới mỏm cùng vai như chấn thương, mang vác, xách nặng... Tuy nhiên trong nghiên cứu này chúng tôi chỉ gặp 2 trường hợp $(6,9 \%)$ có chấn thương, 8 trường hợp $(27,6 \%)$ sau mang vác nặng. Còn phần lớn bệnh xuất hiện tự nhiên chiếm $65,5 \%$. Vị trí đau chủ yếu là vai phải có $15(51,7 \%)$ trường hợp, vai trái có $9(31,0 \%)$ trường hợp và $5(17,2 \%)$ trường hợp đau cả 2 vai. Tương tự như nghiên cứu của Dogu và cộng sự (2012) tiến hành nghiên cứu trên nhóm gồm 23 bệnh nhân được chỉ định tiêm corticosteroidid tại chỗ điều trị hội chứng chèn ép khoang dưới mỏm cùng vai, cho thây đa số vai tổn thương là vai phải với 15 trường hợp chiếm $65,2 \%$ và 8 trường hợp chiếm $34,8 \%$ đau vai trái ${ }^{5}$. Trong nghiên cứu của chúng tôi, nhóm bệnh nhân là nông dân, công nhân, người lao động nặng hay mang vác hoặc động tác lao động thường đưa cánh tay cao hởn $90^{\circ}$, thì tỷ lệ mắc bệnh cao hơn với 55,2 \%. Cụ thể trong nhóm nghiên cứu của chúng tôi, bệnh nhân ở nhóm lao động nặng làm các nghề như công nhân, thợ xây, lái xe, cơ khí, khuân vác, làm ruộng... Ngoài ra, trong nghiên cứu của chúng tôi còn ghi nhận các trường hợp có hoạt động thể lực, thể dục thể thao kèm theo như: bơi lội ghi nhận 2 trường hợp $(6,9 \%)$, yoga có 5 trường hợp $(17,3 \%)$, chơi bóng chuyền, cầu lông có 3 trường hợp (10,3\%).

Kết quả nghiên cứu của chúng tôi cho thấy, điều trị hội chứng chèn ép khoang dưới mỏm cùng vai bằng phương pháp tiêm corticosteroid dưới hướng dẫn siêu âm được đánh giá theo thang điểm VAS, EFA và góc dạng khớp vai có sự cải thiện qua các thời điểm đánh giá. Tại bảng 3 , điểm VAS trung bình trước tiêm là $6,67 \pm 0,84$, sau tiêm 4 tuần là $2,08 \pm 1,31$, điểm VAS trung bìnhso sánh tại hai thời điểm trước tiêm và sau tiêm 4 tuần giảm 4,58 $\pm 1,10(p<0,05)$. Theo nghiên cứu của Cole năm 2015 trên nhóm 27 bệnh nhân với 28 khớp vai được chỉ định tiêm 1 $\mathrm{ml}$ Depomedrol $40 \mathrm{mg}$ vào khoang dưới mỏm cùng vai dưới hướng dẩn siêu âm, theo dõi trong 4 tuần cũng nhận thấy sự cải thiện về điểm đau VAS. Cụ thể, trong nghiên cứu của Cole điểm 
VAS trung bình trước tiêm và sau tiêm 4 tuần giảm từ $5,9 \pm 0,5$ xuống $3,3 \pm 0,6$. Sự khác biệt giữa điểm đau VAS trước và sau tiêm 4 tuần của nghiên cứu này có ý nghĩa thống kê với $p<0,01^{6}$.

Điểm EFA trung bình tăng tại các thời điểm đánh giá, trước tiêm là $9.73 \pm 1.54$ điểm, sau tiêm 4 tuần là $12,62 \pm 1,23$ điểm. Góc dạng khớp vai trung bình cũng tăng tại các thời điểm đánh giá, trước tiêm là 63,08 $\pm 14,30$ độ, sau tiêm 4 tuần là $116,41 \pm 16,84$ độ. Mức tăng trung bình của thang điểm EFA, góc dạng khớp vai so sánh tại 2 thời điểm trước tiêm và sau tiêm lần lượt là $5,55 \pm 2,07$ điểm và $53,23 \pm$ 21,49 độ, có ý nghĩa thống kê với $p<0,05$. Sự cải thiện bắt đầu xuất hiện từ ngày thứ 3 đến 1 tuần sau tiêm, và 4 tuần sau điêuu trị có 8 khớp vai, chiếm 23,5\% không còn đau, một số khớp vai đau ít và cảm thấy khó khăn khi thực hiện các vận động chủ động như đưa tay ra sau, dạng cánh tay... Nhóm bệnh nhân cải thiện mức độ đau, mức độ hoạt động khớp ít hơn, phần lớn nằm trong nhóm bệnh nhân cao tuổi với thời gian bị bệnh tính từ lúc xuất hiện triệu chứng đau đển lúc được điều trị là trên 3 tháng.

Điều trị hội chứng chèn ép khoang dưới mỏm cùng vai bằng phương pháp tiêm tại chỗ corticosteroid dưới hướng dẫn siêu âm được nghiên cứu của Dogu (2012) đánh giá cao về hiệu quả giảm đau và tính ổn định lâu dàikhi thuốc được đưa chính xác vào bao thanh dịch dưới mỏm cùng vai ${ }^{5}$. Mặt khác, phương pháp này ít gây ra các tác dụng không mong muốn trên đường tiêu hóa, tim mạch, tiết niệu... như khi sử dụng thuốc chống viêm, giảm đau NSAIDs đường toàn thân. Vì thế, đây là phương pháp điều trị an toàn, hiệu quả, nên được áp dụng trong điều trị các bệnh lý khớp vai cũng như bệnh lý tại một số khớp khác.

4.2. Tác dụng không mong muốn của liêuu phápđiêuu trị hội chứng chèn ép khoang dưới mỏm cùng vai bằng tiêm corticoid dưới hướng dẫn siêu âm. Trong nghiên cứu của chúng tôi có 34 khớp vai đau được chỉ định tiêm $1 \mathrm{ml}$ Depomedrol $40 \mathrm{mg}$ vào bao thanh dịch dưới mỏm cùng vai dưới hướng dẫn siêu âm. Bệnh nhân được chúng tôi theo dõi các tác dụng không mong muốn tại thời điểm làm thủ thuật và sau làm thủ thuất 1 ngày đến 4 tuần. Tai bảng 4, cho thấy chỉ số mạch, huyết áp của bệnh nhân có tăng nhe sau tiêm, nhưng các chỉ số này vẫn trong giới hạn bình thường và bệnh nhân không có các biểu hiện toàn thân như đau đầu, hoa mắt, chóng mặt, cường phế vị hay chảy máu tại chỗ sau tiêm. Tại thời điểm sau tiêm 1 ngày đến 4 tuần, chúng tôi ghi nhận 12 khớp vai (35,29\%) đau tăng sau tiêm 24 giờ. Tuy nhiên đau ở mức độ nhẹ, tự hết đau sau 48h, bệnh nhân không phải dùng thuốc giảm đau. Ngoài ra, qua theo dõi, chúng tôi không ghi nhận khớp vai nào có biểu hiện nhiễm trùng tại chỗ, teo da, bach biến trên datại thời điểm sau tiêm 1 tuần và 4 tuần.Nghiên cứu của một số tác giả cho thây liệu pháp tiêm corticosteroid điều trị hội chứng chèn ép khoang dưới mỏm cùng vai ít gặp tác dụng phụ toàn thân. Nghiên cứu của Esperanza Naredo năm 2004, thực hiện tiêm corticosteroid tại chỗ cho nhóm 20 bệnh nhân bị đau vai, chỉ ghi nhận 1 trường hợp gặp tác dụng không mong muốn nhe sau tiêm? ${ }^{7}$. Ngoài ra, nghiên cứu của một số tác giả đã thông báo vế tác dụng không mong muốn trên gân chóp xoay khi tiểm corticosteroid tại chỗ nhưng mức độ ảnh hưởng không đáng kể, nhất là khi sử dụng Methylprednisolone và tiêm 1 mũi duy nhất ${ }^{8}$.

\section{KẾT LUẬN}

Nghiên cứu mô tả can thiệp đánh giá kết quả điều trị hội chứng chèn ép khoang dưới mỏm cùng vai bằng phương pháp tiêm corticosteroid dưới hướng dẫn của siêu âm, cho thấy phương pháp này đem lại hiệu quả điều trị tốt, có ý nghĩa thống kê, thông qua đánh giá sự cải thiện về thang điểm VAS, EFA và góc vận động cánh tay. Ngoài ra, đây còn là một liệu pháp an toàn, ít gặp tác dụng không mong muốn như dùng chống viêm Nsaid đường toàn thân.

\section{TÀI LIÊU THAM KHẢO}

1. Charalambous CP, Eastwood S. Anterior Acromioplasty for the Chronic Impingement Syndrome in the Shoulder: A Preliminary Report. In: Banaszkiewicz PA, Kader DF, eds. Classic Papers in Orthopaedics. Springer London; 2014:301-303. doi:10.1007/978-1-4471-5451-8_74

2. Akbari N, Ozen S, Şenlikçi HB, Haberal $M$, Çetin $\mathbf{N}$. Ultrasound-guided versus blind subacromial corticosteroid and local anesthetic injection in the treatment of subacromial impingement syndrome: A randomized study of efficacy. Jt Dis Relat Surg. 2020;31(1):115-122. doi:10.5606/ehc.2020.71056

3. Neer CS. Anterior acromioplasty for the chronic impingement syndrome in the shoulder: a preliminary report. J Bone Joint Surg Am. 1972;54(1):41-50.

4. Dhillon K. Subacromial Impingement Syndrome of the Shoulder: A Musculoskeletal Disorder or a Medical Myth? Malays Orthop J. 2019;13(3):1-7. doi:10.5704/MOJ.1911.001

5. Dogu B, Yucel SD, Sag SY, Bankaoglu M, Kuran B. Blind or Ultrasound-Guided Corticosteroid Injections and Short-Term Response in Subacromial Impingement Syndrome: A 
Randomized, Double-Blind, Prospective Study. Am J Phys Med Rehabil. 2012;91(8):658-665. doi:10.1097/PHM.0b013e318255978a

6. Cole BF, Peters KS, Hackett L, Murrell GAC. Ultrasound-Guided Versus Blind Subacromial Corticosteroid Injections for Subacromial Impingement Syndrome: A Randomized, DoubleBlind Clinical Trial. Am J Sports Med. 2016;44(3):702-707.

doi: $10.1177 / 0363546515618653$
7. Naredo E, Cabero F, Beneyto $\mathbf{P}$, et al. A randomized comparative study of short term response to blind injection versus sonographicguided injection of local corticosteroids in patients with painful shoulder.] Rheumatol. 2004;31(2):308-314.

8. Buchbinder $R$, Green $S$, Youd JM. Corticosteroid injections for shoulder pain. Cochrane Database Syst Rev. 2003;(1):CD004016. doi:10.1002/14651858.CD004016

\section{ĐINH DANH NẤM CANDIDA ALBICANS Ở BÊNNH NHI TẠI BỆNH VIỆN TRƯỜNG ĐẠI HỌC Y KHOA VINH NĂM 2021}

\section{TÓM TẮT}

Nấm Candida là nguyên nhân hàng đầu gây nhiễm nấm ở trẻ em nhập viện. Do trẻ nhỏ có một hệ thống miễn dịch chưa hoàn thiện, các triệu chứng của bệnh do nấm có thể nặng hơn và khó kiểm soát. Các tổn thương ảnh hưởng tới đời sống và sức khỏe của trẻ em. Nghiên cứu mô tả cắt ngang có phân tích được thực hiện tại Khoa khám bệnh của Bệnh viện trường Đại học Y khoa Vinh từ 01/2021 đến 04/2021 trên 42 bệnh nhân là trẻ em dưới 15 tuổi nhiễm nấm. Kết quả cho thấy, tỷ lệ nhiễm nấm C.albicans ở trẻ em $(88,1 \%)$. Chủ yểu nhiễm ở miệng. Có sự ảnh hưởng của huyết thanh có chứa kháng sinh, kháng nấm liên quan đến thời gian sinh ống mầm.

Tư khóa: nhiếm nấm Candida albicans, trẻ em, xét nghiệm định danh

\section{SUMMARY}

\section{IDENTIFICATION OF CANDIDA ALBICANS IN CHILDREN VISITING THE OUTPATIENT DEPARTMENT OF VINH MEDICAL UNIVERSITY HOSPITAL IN 2021}

Candidiasis is the most common cause of invasive fungal infections in hospitalized children. The symptoms of a fungal infection may be more severe and difficult to control in children who have an underdeveloped immune system. Fungal injuries have an impact on the lives and health of children. The cross-sectional descriptive research was conducted on 42 individuals under the age of 15 who were infected with a fungal illness in the Outpatient Department of Vinh Medical University Hospital from January to April 2021. The findings revealed that $88.1 \%$ of children with fundal infection had Candida albicans fungal infection, with oral infections being the most prevalent. There is an effect of serum containing

${ }^{1}$ Bệnh viện Hữu nghi đa khoa Nghệ An

${ }^{2}$ Trường Đai hoc Y khoa Vinh

Chịu trách nhiểm chính: Nguyễn Ngọc Hòa

Email: nguyen.ngochoa.47s@kyoto-u.jp

Ngày nhân bài: 2.8 .2021

Ngày phản biên khoa hoc: 28.9.2021

Ngày duyệt bài: 5.10 .2021

\section{Nguyễn Ngọc Hòa ${ }^{1}$, Nguyễn Thị Hồng Điệp ${ }^{2}$}

antiobiotics, antifungal medicine on the timing of germ tube generation.

Keywords: Candida albicans infection, children, identification test

\section{I. ĐĂT VẤN ĐỀ}

Nấm Candida là nguyên nhân hàng đầu gây nhiễm nấm ở trẻ em nhập viện. Tỷ lệ nhiễm nấm Candida cao nhất ở trẻ sơ sinh và trẻ nhỏ dưới 1 tuổi [1]. Candida albicans là một loài nấn men sống hoại sinh ở miệng, đường tiêu hóa, nếp nhăn trên da có độ ẩm cao khi có điều kiện thuận lợi bắt đâu tăng sinh gây bệnh. Đặc biệt trên đối tượng là trẻ em hệ miển dịch yếu, khả năng tự vệ sinh còn hạn chế nên tắng nguy cơ nhiễm nấm $C$. albicans. Nhiễm nấm $C$. albicans phát triển quá mức có thể gây nhiễm trùng trên da, miệng, tai, mũi, họng, máu.

Tại một số nước trên thế giới ghi nhận trẻ em nhiễm Candida, bệnh nhi tại Bệnh viện Nhi Đại học Cairo tỷ lế trẻ nhiếm trùng máu do $C$. albicans chiếm 17,3\% [1]. Tại Bệnh viện Nhi Trung ương tỉ lệ trẻ sơ sinh nhiễm trùng do nấm C. albicans là $67,3 \%$ [2]. Nghệ An là một tỉnh nằm trong vùng khí hậu nhiệt đới gió mùa là điều kiện thuận lợi cho sự phát triển của nấm. Trên thực tế lâm sàng ghi nhận các bệnh nhi nhiễm nấm. Nghiên cứu này nhằm mục tiêu xác định tỷ lệ nhiểm và kết quả xét nghiệm định danh nấm $C$. albican ở bênh nhi khám tại Bểnh viện Trường Đại học Y khoa Vinh năm 2021.

\section{II. ĐỐI TƯỢNG VÀ PHƯƠNG PHÁP NGHIÊN CỨU}

1. Đối tượng nghiên cứu. Bênh nhi nhiễm nấm đến khám tại Bệnh viện Trường ĐHY khoa Vinh từ tháng 1/2021 đến 4/2021 thỏa mãn điều kiện nghiên cứu.

2. Thiết kế nghiên cứu: mô tả cắt ngang có phân tích 
3. Phương pháp chọn mẫu: chọn mẫu thuận tiện gồm 42 bệnh nhi

4. Thiết bị và qui trình nghiên cứu

- Thu thập thông tin bệnh nhân, lấy mẫu bệnh phẩm và tiến hành soi tươi.

- Sau khi nhận định sơ bộ là Candida sẽ tiến hành nuôi cấy trên Sabouraud kháng sinh, môi trường bột bắp, môi trường lên men đường, huyết thanh người.

- Nhuộm soi lại khuẩn lạc đã mọc để kiểm tra lại.

- Thử nghiệm sinh ông mầm, sinh bài tử dày, tính chất sinh hóa.

\section{Các chỉ số nghiên cứu}

- Chỉ số về tỷ lệ: tỷ lệ nhiễm nấm C. albicans, tỷ lệ nhiễm nấm theo tuổi, giới tính, nơi sống, tỷ lệ phân bố theo bệnh phẩm.

- Chỉ số về định danh nấm: Thử nghiệm sinh ống mầm, thử nghiệm sinh bào tử dày, tính chất lên men đường, đồng hóa đường, nuôi cây trong môi trường Sabouraud lỏng

6. Phương pháp xử lý số liệu. Xử lý bằng phần mềm SPSS 20.0

\section{KẾT QUẢ NGHIÊN CỨU}

\section{1 Đặc điểm mẫu nghiên cứu}

Bảng 3.1 Đặc điểm mẫu nghiên cứu

\begin{tabular}{|c|c|c|c|}
\hline & $\begin{array}{c}\text { Tân số } \\
(\mathrm{N}=42)\end{array}$ & $\begin{array}{l}\text { Tỉ lệ } \\
(\%)\end{array}$ \\
\hline \multirow{2}{*}{ Giới } & Nam & 29 & 69 \\
\hline & Nứ & 13 & 31 \\
\hline \multirow{4}{*}{ Tuổi } & 0 -24 tháng & 26 & 61,9 \\
\hline & 25 -60 tháng & 11 & 26,2 \\
\hline & $61-120$ tháng & 4 & 9,5 \\
\hline & $121-180$ tháng & 1 & 2,3 \\
\hline \multirow{2}{*}{$\begin{array}{l}\text { Cư } \\
\text { trú }\end{array}$} & Đô thị & 10 & 23,8 \\
\hline & Nông thôn & 32 & 72,6 \\
\hline
\end{tabular}

Nhân xét: Có 42 bênh nhân đến khám được xác định nhiễm nấm trong đó có 29 trẻ nam chiếm tỉ lệ $69 \%$ và 13 trẻ nữ chiếm tỉ lê $31 \%$. Trẻ em ở độ tuổi 0 - 24 tháng chiếm tỉ lệ cao nhất 61,9\% (26/42) so với các độ tuổi khác. Các bệnh nhân đến khám chiếm 76,2\% (32/42) phần lớn đến từ vùng nông thôn.

Bảng 3.2 Tỷ lệ phân bố nấm C. albicans theo mấu bệh phẩm

\begin{tabular}{|c|c|c|c|c|}
\hline $\begin{array}{c}\text { Mâu bệ̂nh } \\
\text { phẩm }\end{array}$ & $\mathbf{n ( + ) / N}$ & $\begin{array}{c}\text { Tỉ lề } \\
(\%)\end{array}$ & $\mathbf{X}^{\mathbf{2}}$ & $\mathbf{P}$ \\
\hline $\begin{array}{c}\text { Nấm } \\
\text { miệng }\end{array}$ & $19 / 42$ & 45,2 & & \\
\cline { 1 - 3 } Phân & $16 / 42$ & 38,1 & \multirow{2}{*}{20,228} & $\mathbf{0 , 0 0 0}$ \\
\cline { 1 - 3 } $\begin{array}{c}\text { Nấm tai } \\
\text { ngoài }\end{array}$ & $2 / 42$ & 4,8 & & \\
\hline Vảy da & $0 / 42$ & 0,0 & & \\
\cline { 1 - 2 }
\end{tabular}

n (+): Số lượng mẫu dương tính với nấm C. albicans; N: số mẫu nhiễm nấm

Nhận xét: Tî lệ phân bố C.albicans theo bệnh phẩm ở miệng chiếm $45,2 \%$, phân chiếm $38,1 \%$, nấm tai ngoài chiếm $4,8 \%$, vảy da $0 \%$

3.2 Tỉ lệ nhiễm nấm Candida albicans ở trẻ em

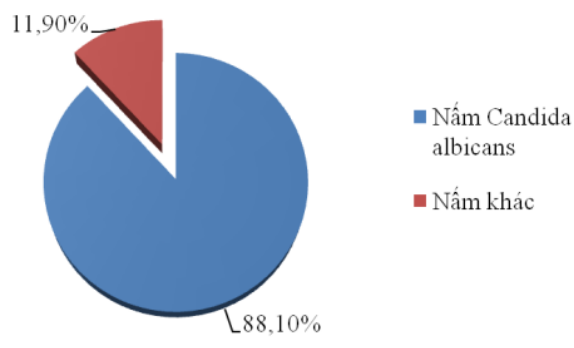

\section{Biểu đồ 3.1 Tỉ lệ nhiếm nấm C. albicans ở trẻ đến khám}

Nhân xét: Tỉ lê nhiễm nấm C. albicans $88,1 \%$ (37/42) và tỉ lệ nhiểm các nấm khác là $11,9 \%$.

3.3 Nhật xét kết quả xét nghiệm định danh nấm C. albicans

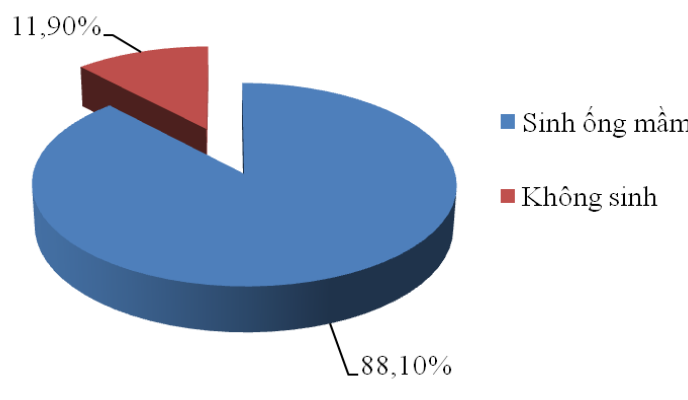

Biểu đồ 3.2 Thử nghiệm sinh ống mầm

Nhận xét: Tỉ lệ sinh ống mầm là $88,1 \%$ và không sinh ống mầm là $11,9 \%$

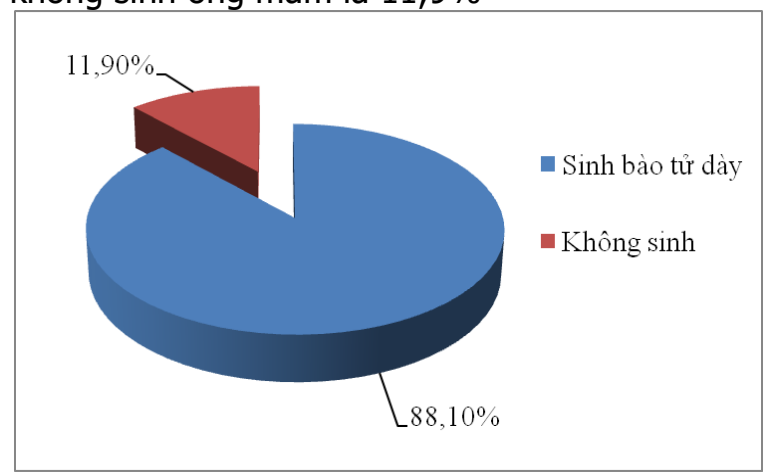

Biểu đồ 3.3. Thử nghiệm tìm bào tử dày

Nhận xét: Theo biểu đồ có 88,1\% (37/42) mẫu được xác định ban đầu là Candida có sinh bào tử dày và $11,9 \%$ không sinh bào tử dày 
Bảng 3.3. Các đặc điểm để định danh nấm C. albicans

\begin{tabular}{|c|c|c|c|c|c|c|c|c|c|c|}
\hline \multirow{2}{*}{ Loại nấm } & SBR & \multicolumn{4}{|c|}{ Lên men } & \multicolumn{4}{c|}{ Đông hóa } \\
\cline { 3 - 11 } & lỏng & G & M & S & L & G & M & S & L & Ga \\
\hline Candida albicans & Lắng cặn & $\mathrm{AH}$ & $\mathrm{AH}$ & $\mathrm{AH}$ & $\mathrm{AH}$ & + & + & + & + & + \\
\hline Candida khác & Váng & $\mathrm{AH}$ & $\mathrm{AH}$ & $\mathrm{AH}$ & - & + & + & + & - & + \\
\hline
\end{tabular}

Nhận xét: Tiến hành làm xét nghiệm thử tính chất sinh hóa học của các mấu bệnh phẩm cho thấy $100 \%$ mẫu được định danh là nấm $C$. albicans qua sinh ống mầm và sinh bào tử dày đều lên men và đồng hóa tất cả các loại đường trên môi trường Pepton. Trên môi trường SBR lỏng cho kết quả lắng cặn.

\section{BÀN LUÂ̂N \\ 4.1 Xác định tỷ lệ nhiễm nấm C. albicans ở trẻ em}

4.1.1 Ti lê nhiễm nấm C. albicans ở trẻ em. Qua các kết quả xét nghiệm định danh nấm C.albicans cho thấy phần lớn bệnh nhân nhiễm nấm C.albicans 88,1\% (37/42) cao hơn nhiều so với các nấm khác chiếm tî lệ $11,9 \%$. Tỷ lệ trên có khác biệt với kết quả nghiên cứu Thái Bằng Giang, Khu Thị Khánh Dung tỉ lệ nhiễm nấm C.albicans là 67.3\% [3], của Ifeoma $M$ Ezeonu là C.albicans có tỷ lệ phố biến cao nhất 59\% [4]. Sự khác biệt về tỳ lệ nhiễm nấm có thể là do sự khác biệt về bệnh phẩm, các nghiên cứu trên thu thập trên thu thập thuần nhất một loại bệnh phẩm nhất định (dịch hầu họng, phân...), nghiên cứu của chúng tôi thu thập nhiêu loại mẫu bệnh phẩm khác nhau. Hơn nữa, địa điểm nghiên cứu ở các vùng vị trí địa lý, khí hậu, điều kiện vệ sinh khác biệt nhiểu nên ảnh hưởng đến tỷ lệ nhiễm nấm.

4.1.2 Tỉ lệ phân bố nấm C. albicans theo mấu bệnh phẩm. Tỷ lệ phân bố bệnh phẩm tại miệng chiếm tỷ lệ cao $45,2 \%$ (19/42) và phân chiếm $38,1 \%(16 / 42)$, có sự khác biệt về tỷ lệ nhiễm nấm $\left.x^{2}=20,228 ; d f=2 ; p<0.05\right)$. Kết quả phù hợp với đặc điểm ký sinh của nấm $C$. albicans phân bố nhiều ở miệng. Trong điều kiện bình thường $\mathrm{C}$. albicans sống hoại sinh ở miệng, đường tiêu hóa, nếp nhăn trên da có độ ẩm cao khi có điều kiện thuận lợi bắt đầu tăng sinh gây bệnh. Đặc biệt trên đối tượng là trẻ em hệ miễn dịch yếu nên rất thuận lợi cho nấm $C$. albicans phát triển và gây bệnh.

4.2 Nhật xét kêt quả xét nghiệm định danh nấm C. Albicans. Tỉ lệ sinh ổng mầm chiếm tỷ lệ 88,1\% (37/42). Sau 2 giờ ủ ở nhiệt độ $370 \mathrm{C}$ có $55,3 \%$ sinh ống mầm dài và đẹp. Sau 4 giờ ủ thì $69,1 \%$ các mẫu sinh ống mầm dài và đẹp. Có 8 mẫu sau 6 giờ ống mầm mới xuất hiện (19\%). Nguyên nhân mẫu mọc ống mầm chậm do huyết thanh được sử dụng. Việc sử dụng huyết thanh gộp từ nhiều bệnh nhẩn hoặc huyết thanh của bệnh nhân đã dùng kháng sinh hoặc kháng nấm sẽ̃ có nguy cơ ảnh hưởng đến khả năng sinh ống mầm gây âm tính giả.

Thử nghiệm sinh bào tử dày, có $88,1 \%$ (37/42) mẩu được xác định ban đầu là Candida có sinh bào tử dày. Quan sát qua 48 giờ các mẫu sinh bào tử dày qua 72 giờ thì trên tất cả các mẫu đều xuất hiện các sợi nấm. Nghiên cứu này được tiến hành trong giai đoạn mùa xuân nên nhiệt độ tại phòng luôn trong khoảng $23-26^{\circ} \mathrm{C}$ đây là ngưỡng nhiệt nằm trong khoảng nhiệt độ lý tưởng $\left(18-26^{\circ} \mathrm{C}\right)$ cho thử nghiệm sinh bào tử dày. Đế củng cố kết quả chúng tổi tiến hành làm xét nghiệm thử tính chất sinh hóa học của các mẫu bệnh phẩm cho thây kết quả phù hợp với đặc tính của $C$.albicans

\section{KẾT LUÂ̂N}

- Tỉ lệ nhiễm nấm C. albicans ở trẻ em có tỷ lệ $88,1 \%$.

- Có sự ảnh hưởng của huyết thanh có chứa kháng sinh, kháng nấm liên quan đến thời gian sinh ống mầm.

- Thử nghiệm sinh bào tử dày đạt kết quả mọc trong ngưỡng thời gian cho phép 48 - 96 giờ ở nhiệt độ $23^{\circ} \mathrm{C}-26^{\circ} \mathrm{C}$

\section{TÀI LIÊU THAM KHẢO}

1. Elpis Mantadakis, Zoe Dorothea Pana, Theoklis Zaoutis (2018), Candidemia in children: Epidemiology, prevention and management, Mycoses Editor's Choice, 61(9), pages 614-622, DOI: https://doi.org/10.1111/myc.12792

2. Khairat SM, Sayed AM, Nabih M, Soliman NS, Hassan YM (2019), "Prevalence of Candida blood stream infections among children in tertiary care hospital: detection of species and antifungal susceptibility" Journals Infection and Drug Resistance, Volume 12 (5) Pages 24092416. DOI: https://doi.org/10.2147/IDR.S196972

3. Thái Bằng Giang, Khu Thị Khánh Dung (2018), "Đặc điểm dịch tế hoc lâm sàng nhiếm trùng do nấm ở trẻ sơ sinh điều trị tại khoa sơ sinh Bệnh viện Nhi trung ương từ tháng $2 / 2016-2 / 2017^{\prime \prime}$. Y học TP.Hồ Chí Minh, Phụ bản tập 22, số 4, 2018, trang 77-85

4. Ifeoma M Ezeonu, Ntun W Ntun, Kenneth 0 Ugwu (2017), "Intestinal candidiasis and antibiotic usage inchildren: case study of Nsukka, South Eastern Nigeria", Afr Health Sci. 17(4), pp. 11781184. DOI: $10.4314 /$ ahs.v17i4.27 


\title{
Mô TẢ MộT Số ĐĂC ĐIỂM LÂM SÀNG VÀ CẬN LÂM SÀNG Ơं BÊNH NHÂN XO' GAN
}

\author{
Phạm Cẩm Phương*, Võ Thị Thúy Quỳnh*, Phạm Văn Thái*,

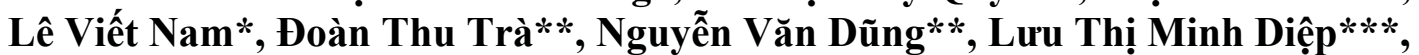 \\ Lê Thị Bích Ngọc*, Bùi Bích Mai*, Hoàng Quốc Bình* và cộng sự
}

\section{TÓM TẮT}

Muc tiêu: Mô tả mô̂t số đăc điểm lâm sàng và cân lâm sàng ở bệnh nhân xơ gan. Đối tượng và phương pháp: Nghiên cứu mố tả tiến cứu trên 102 đối tượng xơ gan do virus và không do virus. Kết quả: Tuổi trung bình của bệnh nhân xơ gan là $56,97 \pm 11,59$, tỉ lệ nam/nữ là 5,8/1. Các nguyên nhân gây xơ gan đa phần là do viêm gan $B$, và do rượu. Các triêuu chứng lâm sàng thường gắp trong nhóm xơ gan là chán ăn, mệt mỏi, đau tức hạ sườn phải, tuần hoàn bàng hệ với tî̉ lệ 38,2\%, 46,1\%,40,2\% 40,2\%. Các triệu chứng lâm sàng ít gặp là buồn nôn, ngứa, rối loạn tiêu hoá, gan to. Nồng độ trung bình AFP, AFPL3\% và PIVKA-II ở nhóm bệnh nhân Xơ gan nói chung lần lướt là $86,8 \mathrm{ng} / \mathrm{mL}, 6,2 \%$ và $246,98 \mathrm{mAU} / \mathrm{mL}$. Nồng độ trung bình AFP, AFP-L3\% và PIVKA-II ở nhóm bệnh nhân xơ gan có tăng một trong ba chỉ số là $163,99 \mathrm{ng} / \mathrm{mL}, 11 \%$ và 458,4 mAU/mL. Kết luận: Ơ các bệnh nhân xơ gan; nồng độ AFP, AFP-L3 và PIVKA-II có thể tăng không cao nhiêuu so với người bình thường.

\section{SUMMARY \\ DESCRIBING SOME CLINICAL AND PARACLINICAL CHARACTERISTICS IN CIRRHOSIS PATIENTS}

Objective: To describe clinical and subclinical characteristics in cirrhotic patients. Subject and method: A prospective descriptive study on 102 liver cirrhosis patients. Results: The mean age of liver cirrhosis patients was $56.97 \pm 11.59$, the male/female ratio was $5.8 / 1$. The most common causes of cirrhosis were hepatitis $\mathrm{B}$, and alcohol. Common clinical symptoms in cirrhosis group were anorexia, fatigue, right upper quadrant pain, collateral circulation with the rate of $38.2 \%, 46.1 \%, 40.2 \%, 40.2 \%$. Less common clinical symptoms are nausea, itching, digestive disorders, hepatomegaly. The average concentration of AFP, AFP-L3\% and PIVKA-II in the cirrhotic group were $86.8 \mathrm{ng} / \mathrm{mL}, 6.2 \%$ and 246.98 $\mathrm{mAU} / \mathrm{mL}$, respectively. Median AFP, AFP-L3\% and PIVKA-II levels in the group of patients had increased in one of the three indices, which were $163.99 \mathrm{ng} / \mathrm{mL}$, $11 \%$ and $458.4 \mathrm{mAU} / \mathrm{mL}$. Conclusion: In cirrhotic

*Trt Y học hạt nhân và Ung bướu, Bênh viện Bạch Mai **Trung tâm Bênh nhiệt đới, Bênh viện Bạch Mai ***Trt tiêu hóa gan mầt tuy, Bênh viên Bach Mai Chịu trách nhiệm chính: Phạm Cẩm Phương

Email: phamcamphuong@gmail.com

Ngày nhận bài: 2.8 .2021

Ngày phản biên khoa học: 4.10.2021

Ngày duyệt bài: 13.10.2021 patients; of AFP, AFP-L3 and PIVKA-II may be elevate in benign levels

\section{I. ĐẶT VẤN ĐỀ}

Xơ gan là một bệnh lý rất thường gặp, nguyên nhân thường do viêm gan virus $B$ (chiếm khoảng $37 \%$ ), viêm gan virus C (chiếm khoảng $20 \%$ ), do rượu (chiếm khoảng 20\%) và các nguyên nhân khác [1]. Xơ gan thường xảy ra sau mười đến hai mươi năm ở khoảng 20 đến $30 \%$ bệnh nhân bị viêm gan $B, C$. Việt Nam nằm trong vừng dịch tễ lưu hành viêm gan $\mathrm{B}$ với tỷ lệ mắc chiếm khoảng 15 - 20\% và viêm gan C chiếm tỷ lệ khoảng 8 - 10\% dân số, biến chứng thường gặp nhất là xơ gan và ung thư gan [1], [2]. Ngoài viêm gan virus $B, C$ mạn tính, các yếu tố nguy cơ khác dẫn đến xơ gan gồm có: uống rượu, thiếu men anpha1 - antitrypsin...

Trong chẩn đoán ung thư biểu mô tế bào gan thì alphafetoprotein (AFP) được coi là một chất chỉ dấu ung thư và được ứng dụng trong lâm sàng nhiêu nhất. Ở người lớn khỏe mạnh (phụ nữ không mang thai), mức độ AFP huyết thanh chỉ từ $0-10 \mathrm{ng} / \mathrm{ml}$. Tuy nhiên, ở bệnh nhân xơ gan nông độ AFP có thể tăng lên đến $40 \%$. Bệnh nhân ung thư biểu mô tế bào gan có thể có nổng độ AFP dao động từ ngương bình thường cho đến > 100.000 ng/mL [3]. AFP-L3 là dạng đồng phân của AFP có đặc tính ái lực cao với Lens culinaris agglutinin (LCA). AFP-L3 tăng trong huyết thanh có độ đăc hiêu cao cho ung thư biểu mô tế bào gan. PIVKA-II là một dang bất thường được tạo ra bởi sự thiếu Vitamin K của prothrombin, một yếu tố đông máu được sản xuất bởi gan, nồng độ PIVKA-II bình thường thấp hơn $40 \mathrm{mAU} / \mathrm{mL}$. Nhiêu nghiên cứu trên thế giới cho thấy PIVKA-II có độ nhạy cao hơn và có giá trị chẩn đoán độc lập so với chỉ điểm AFP trong việc chẩn đoán sớm ung thư biểu mô tế bào gan. Khi kết hợp 3 chất chỉ điểm PIVKA-II với AFP và AFP-L3 sẽ làm tăng tỷ lệ phát hiện ung thư biểu mô tế bào gan [4]. Ung thư gan có tỷ lệ sống sót sau 5 năm trên $70 \%$ nếu bệnh nhân được chẩn đoán ở giai đoạn sớm, tuy nhiên để chẩn đoán sớm HCC là phức tạp bởi sự cùng tồn tại của viêm gan mạn hoặc xơ gan [5]. Đa số HCC phát triển trên nền gan xơ (châu Á: 70- 
90\%). Xơ gan càng nặng thì khả năng bị ung thư gan càng cao [6]. Việc bổ sung thêm các dấu ấn sinh học để phân biệt ung thư biểu mô tế bào gan với xơ gan là cần thiết và hữu hiệu cho bác sỹ lâm sàng chẩn đoán bệnh khi chưa có triệu chứng.

Các bệnh nhân xơ gan có tăng nồng độ AFP, AFP-L3\% và PIVKA-II có nguy cơ mắc ung thư gan, tuy nhiên cũng có những trường hợp có tăng nhưng chỉ là tăng lành tính, không có tổn thương u, không có ung thư gan. Nhằm đánh giá đặc điểm lâm sàng và cận lâm sàng ở bệnh nhân xớ gan, chúng tôi tiến hành nghiên cứu này với mục tiêu: Mô tả một số đặc điểm lâm sàng, cận lâm sàng và nồng độ AFP, AFP - $\angle 3$ và PIVKA-II của nhóm bệnh nhân xơ gan.

\section{II. ĐỐI TƯỢNG VÀ PHƯƠNG PHÁP NGHIÊN CỨU}

Đối tượng nghiên cứu: 102 bệnh nhân xơ gan tại Bệnh viện Bạch Mai và một số bệnh viện trong khu vực Hà Nội từ tháng 10 năm 2019 đến tháng 3 năm 2021.

Đối tượng tham gia nghiên cứu: bệnh nhân xơ gan do viêm gan $B$, viêm gan $C$, xơ gan, xơ gan không do virus viêm gan.

Phương pháp nghiên cứu: mô tả tiến cứu

\section{KẾT QUẢ NGHIÊN CỨU}

\section{Bảng 10. Đặc điểm tuổi của đôî tượng} nghiên cứu

\begin{tabular}{|c|c|c|}
\hline Nhóm tuối & Số lượng & Tỷ lệ \% \\
\hline$\leq 40$ tuối & 11 & 10,8 \\
\hline $41-70$ tuối & 77 & 75,5 \\
\hline$>70$ tuối & 14 & 13,7 \\
\hline Tống & $\mathbf{1 0 2}$ & $\mathbf{1 0 0}$ \\
\hline \multicolumn{2}{|c|}{ Tuối trung }
\end{tabular}

Tuối trung bình: 56,97 $\pm 11,59$

Nhân xét: Nhóm tuối có tỷ lệ cao nhất là nhóm 41-70 tuổi. Tuổi trung bình của đối tượng xơ gan là 56 , trẻ nhất là 26 tuối, già nhất là 83 tuổi.

Bảng 2. Đặc điểm giới của đối tượng nghiên cứu

\begin{tabular}{|c|c|c|}
\hline & Số lượng & Tỷ lệ \% \\
\hline Nam & 87 & 85,3 \\
\hline Nữ & 15 & 14,7 \\
\hline Tống & $\mathbf{1 0 2}$ & $\mathbf{1 0 0}$ \\
\hline
\end{tabular}

Nhận xét: Nam giới xơ gan gặp nhiều hơn nữ giới. Tỉ lệ nam/nữ là 5,8/1.

Bảng 3. Đặc điểm nguyên nhân gây bệh

\begin{tabular}{|c|c|c|c|c|c|c|}
\hline & $\begin{array}{c}\text { HBV } \\
(\mathbf{n}, \mathbf{\%})\end{array}$ & $\begin{array}{c}\text { HCV } \\
(\mathbf{n}, \mathbf{\%})\end{array}$ & $\begin{array}{c}\text { HBV+HCV } \\
(\mathbf{n}, \mathbf{\%})\end{array}$ & $\begin{array}{c}\text { Rượu } \\
(\mathbf{n}, \mathbf{\%})\end{array}$ & $\begin{array}{c}\text { Rượu+HBV } \\
(\mathbf{n}, \mathbf{\%})\end{array}$ & $\begin{array}{c}\text { Rượu+HCV } \\
(\mathbf{n}, \mathbf{\%})\end{array}$ \\
\hline Có & $65(63,7)$ & $5(4,9)$ & $2(2)$ & $51(50)$ & $32(31,4)$ & $4(3,9)$ \\
\hline Không & $37(36,3)$ & $97(95,1)$ & $100(98)$ & $51(50)$ & $70(68,6)$ & $98(96,1)$ \\
\hline Tống & $\mathbf{1 0 2}$ & $\mathbf{1 0 2}$ & $\mathbf{1 0 2}$ & $\mathbf{1 0 2}$ & $\mathbf{1 0 2}$ & $\mathbf{1 0 2}$ \\
\hline
\end{tabular}

Nhận xét: Có $63,7 \%$ bệnh nhân xơ gan do viêm gan $B, 4,9 \%$ bệnh nhân xơ gan do viêm gan $C$, $2 \%$ bệnh nhân xơ gan mắc cả viêm gan $B$ và $C, 50 \%$ bệnh nhân xơ gan do rượu

Bảng 4. Đặc điểm lâm sàng của đôi tượng nghiên cứu

\begin{tabular}{|c|c|c|}
\hline Đặc điểm & Số lượng & Tỷ lệ $\%$ \\
\hline Chán ăn & 39 & 38,2 \\
\hline Mệt mỏi & 47 & 46,1 \\
\hline Buồn nôn & 11 & 10,8 \\
\hline Gầy sút cân & 11 & 10,8 \\
\hline Đau bụng hạ sườn phải & 21 & 20,6 \\
\hline Chướng bụng & 34 & 33,3 \\
\hline Vàng da, vàng mắt & 33 & 32,4 \\
\hline Ngứa & 9 & 8,8 \\
\hline Rối loạn tiêu hoá & 6 & 5,9 \\
\hline Gan to & 8 & 7,8 \\
\hline Tuần hoàn bàng hệ & 41 & 40,2 \\
\hline Phù & 19 & 18,6 \\
\hline Hội chứng vàng da & 24 & 23,5 \\
\hline Lách to & 41 & 40,2 \\
\hline Cố trướng & 24 & 23,5 \\
\hline
\end{tabular}

Nhận xét: Các triệu chứng lâm sàng thường gặp là chán ăn, mệt mỏi, lách to, tuần hoàn bàng hệ. Các triệu chứng lâm sàng ít gặp là ngứa, rổi loạn tiêu hoá, gan to.

Bảng 5. Đặc điểm cận lâm sàng của đôi tượng nghiên cứu

\begin{tabular}{|c|c|c|}
\hline $\begin{array}{c}\text { Đặc điếm } \\
\text { Hồng câu }(\mathrm{T} / \mathrm{L})\end{array}$ & \multicolumn{2}{|c|}{$4,1 \pm 0,9$} \\
\hline Huyết sắc tố $(\mathrm{g} / \mathrm{L})$ & $126,4 \pm 29,5$ \\
\hline Tiều cầu $(\mathrm{G} / \mathrm{L})$ & \multicolumn{2}{|c|}{$127,3 \pm 67,2$} \\
\hline $\mathrm{PT}(\%)$ & $70,5 \pm 22,4$ \\
\hline Glucose $(\mathrm{mmol} / \mathrm{L})$ & \multicolumn{2}{|c|}{$6,7 \pm 3,4$} \\
\hline Ure $(\mathrm{mmol} / \mathrm{L})$ & \multicolumn{2}{|c|}{$5,8 \pm 2,8$} \\
\hline Creatinin $(\mu \mathrm{mol} / \mathrm{L})$ & \multicolumn{2}{|c|}{$80,9 \pm 27,6$} \\
\hline Đặc điểm & $\begin{array}{c}\text { Giá trị } \\
\text { trung bình }\end{array}$ & $\begin{array}{c}\text { Giá trị } \\
\text { trung vị }\end{array}$ \\
\hline AST $(\mathrm{U} / \mathrm{L})$ & $140,8 \pm 266$ & 59,5 \\
\hline ALT $(\mathrm{U} / \mathrm{L})$ & $90,7 \pm 157,1$ & 46,5 \\
\hline $\begin{array}{c}\text { Bilirubin toàn phần } \\
(\mu \mathrm{mol} / \mathrm{L})\end{array}$ & $41,3 \pm 120,9$ & 35,3 \\
\hline Albumin $(\mathrm{g} / \mathrm{L})$ & $36,4 \pm 23,1$ & 17,3 \\
\hline $\begin{array}{c}\mathrm{HBV}-\mathrm{DNA} \\
\text { (copies/mL) }\end{array}$ & $5,2 \times 10^{7} \pm 1,5 \times 10^{8}$ & $1,4 \times 10^{4}$ \\
\hline $\begin{array}{c}\mathrm{HCV}-\mathrm{RNA} \\
\text { (copies/mL) }\end{array}$ & $8,7 \times 10^{6} \pm 1,3 \times 10^{7}$ & $4,8 \times 10^{6}$ \\
\hline
\end{tabular}

Nhận xét: Các giá trị trung bình AST là $140,8 \pm 266$ và của $A L T$ là $90,7 \pm 157 \mathrm{U} / \mathrm{L}$, cao hơn 
các giá trị của người bình thường. Tải lượng virus HBV-DNA là $5,2 \times 10^{7} \pm 1,5 \times 10^{8}$ copies $/ \mathrm{mL}$, tải lượng virus HCV-DNA là $8,7 \times 10^{6} \pm 1,3 \times 10^{7}$ copies $/ \mathrm{mL}$. Có $3 / 32$ bệnh nhân có tải lượng HBV dưới ngưỡng: 1 bệnh nhân <58,2 copies $/ \mathrm{mL}, 1$ bệnh nhân <116 copies /mL và 1 bệnh nhân $<100$ copies $/ \mathrm{mL}$

Bảng 6. Phân loại Child-pugh của đôî́ tượng nghiên cứu

\begin{tabular}{|c|c|c|}
\hline & Số lượng & Tỷ lệ \% \\
\hline Child-pugh A & 65 & 63,7 \\
\hline Child-pugh B & 32 & 31,4 \\
\hline Child-pugh C & 5 & 4,9 \\
\hline Tống & $\mathbf{1 0 2}$ & $\mathbf{1 0 0}$ \\
\hline
\end{tabular}

Nhận xét: Đa phần bệnh nhân là Chid-pugh A là $63,7 \%$, Child-pugh $C$ chiếm tỷ lệ nhỏ nhất với $4,9 \%$

Bảng 7. Nồng độ AFP, AFP-L3, PIVKA II

\begin{tabular}{|c|c|c|c|c|}
\hline \multirow{2}{*}{} & \multicolumn{2}{|c|}{$\begin{array}{c}\text { Giá tri bình } \\
\text { thường }\end{array}$} & \multicolumn{2}{c|}{$\begin{array}{c}\text { Giá trị bất } \\
\text { thường (tăng) }\end{array}$} \\
\cline { 2 - 5 } & $\begin{array}{c}\text { Số } \\
\text { lượng }\end{array}$ & $\begin{array}{c}\text { Tỹ lệ } \\
\text { \% }\end{array}$ & $\begin{array}{c}\text { Số } \\
\text { lượng }\end{array}$ & $\begin{array}{c}\text { Tỹ lệ } \\
\text { \% }\end{array}$ \\
\hline AFP $(\mathrm{ng} / \mathrm{mL})$ & 33 & 32,3 & 69 & 67,7 \\
\hline $\begin{array}{c}\mathrm{AFP}-\mathrm{L} 3 \% \\
\text { (ng/mL) }\end{array}$ & 20 & 19,6 & 82 & 80,4 \\
\hline $\begin{array}{c}\mathrm{PIVKA}-\mathrm{II} \\
\text { (mAU/mL) }\end{array}$ & 33 & 32,3 & 69 & 67,7 \\
\hline
\end{tabular}

Nhân xét: Hơn 1/3 số bênh nhân xơ gan có tăng nồng độ AFP, AFP-L3, PIVKA II trong đó 66,7\% bệnh nhân có tăng AFP, PIVKA II; 80,4\% bệnh nhân có tăng AFP-L3.

Bảng 8. Nồng độ AFP, AFP-L3, PIVKA II

\begin{tabular}{|c|c|c|c|}
\hline & $\begin{array}{c}\text { Giá trị } \\
\text { trung } \\
\text { bình }\end{array}$ & $\begin{array}{c}\text { Giá trị } \\
\text { trung } \\
\text { vị }\end{array}$ & $\begin{array}{c}\text { Khoảng } \\
\text { tứ phân } \\
\text { vị }\end{array}$ \\
\hline AFP & $86,8 \pm$ & 5,5 & $2,2-$ \\
$(\mathrm{ng} / \mathrm{mL})$ & 566,4 & 13,9 \\
\hline $\mathrm{AFP}-\mathrm{L} 3 \%$ & $6,2 \pm$ & 0 & $0-9,1$ \\
$(\mathrm{ng} / \mathrm{mL})$ & 11,4 & 0 & $14,0-$ \\
\hline $\mathrm{PIVKA}-\mathrm{II}$ & $246,98 \pm$ & 20,5 & 81,5 \\
$(\mathrm{mAU} / \mathrm{mL})$ & 875,2 & 20,5 & \\
\hline
\end{tabular}

Nhân xét: Giá trị trung bình của các chỉ số AFP, AFP-L3, PIVKA II ở nhóm bệnh nhân xơ gan chưa phát triển thành ung thư gan so là cao hơn so với giá trị ở người bình thường.

Bảng 8. Nồng độ AFP, AFP-L3, PIVKA II ơ nhóm tăng mốt trong 3 chỉ số

\begin{tabular}{|c|c|c|c|}
\hline & $\begin{array}{c}\text { Giá trị } \\
\text { trung bình }\end{array}$ & $\begin{array}{c}\text { Giá trị } \\
\text { trung vị }\end{array}$ & $\begin{array}{c}\text { Khoảng tứ } \\
\text { phân vị }\end{array}$ \\
\hline $\begin{array}{c}\mathrm{AFP} \\
(\mathrm{ng} / \mathrm{mL})\end{array}$ & $\begin{array}{c}163,99 \pm \\
781,4\end{array}$ & 12,6 & $5,7-64,8$ \\
\hline $\begin{array}{c}\mathrm{AFP}-\mathrm{L} 3 \% \\
(\mathrm{ng} / \mathrm{mL})\end{array}$ & $\begin{array}{c}11,3 \pm \\
13,8\end{array}$ & 8,1 & $2,3-8,1$ \\
\hline $\mathrm{PIVKA}-\mathrm{II}$ & $458,4 \pm$ & 79,0 & $18,0-$ \\
$(\mathrm{mAU} / \mathrm{mL})$ & 1180,2 & 237,0 \\
\hline
\end{tabular}

Nhận xét: Các chỉ sổ AFP, AFP-L3, PIVKA II có thể tăng đồng thời, hoăc riêng lẻ một trong ba chỉ số. Giá trị trung bình của các chỉ số ở nhóm bệnh nhân tăng một trong ba chỉ số cao hơn chỉ số bình thường AFP 163,99 ng/mL, 11\% và PIVKA-II ở mức 458,4 mAU/mL

\section{BÀN LUÂN}

Trong nghiên cứu của chúng tôi, tỷ lệ bệnh nhân nam giới chiếm đa số là $85,3 \%$, nữ giới chiếm tỷ lệ là $14,7 \%$, tỷ lệ nam/nữ là $5,8 / 1$, tuổi trung bình cả nam và nữ là 56 tuổi, trẻ nhất là 26 tuổi, già nhất là 83 tuổi. Kết quả này tương đương với kết quả nghiên cứu của các tác giả trên thế giởi với tỉ lệ xơ gan ở nam giới cao hơn nữ giới vì thường liền quan đến xơ gan do rượu, do viêm gan $B$, viêm gan $C$. Bệnh lý xớ gan thường gặp ở lứa tuổi trung niên. Trong nghiên cứu của chúng tôi, tần suất lứa tuổi này (46-55) là cao nhất $(25 \%)$. Kết quả này cũng phù hợp với y văn vì bệnh này thường xảy ra sau khi các nguyên nhân gây xớ hóa gan tấn công vào cơ thể dẫn đến hủy hoại tế bào gan rồi đến xơ hóa kéo dài nhiều năm. Đ̇a số nguyên nhân gây bệnh chủ yếu là viêm gan mạn tính do rượu, viêm gan virus $B$ và $C$; thường bắt đầu ở tuổi trưởng thành và gây bệnh lý gan mạn tính 10-20 năm sau. Điều này cũng hợp lý vì Việt Nam là vùng dịch tễ cao của viêm gan do virus đặc biệt virus $B$ và $C$. So với các tác giả nước ngoài, tuổi trong nghiên cứu của chúng tôi cũng tương đương. Trong nghiên cứu của Juliette Foucher và cs trên 711 bệnh nhân, tuổi trung bình là $52 \pm 13$. Kết quả này cao hơn so với một số các nghiên cứu của các tác giả trong và ngoài nước. Theo nghiên cứu trong nước, tỷ lệ nam/nữ là 1,2-2,4; thường gặp ở nam nhiêuu hơn nữ. Điều này cũng phù hợp với dịch tễ học của bệnh trên thế giới nói chung cũng như khu vực Đông Nam Á và Việt Nam nói riêng. Sở dĩ có tî lệ nam cao hơn nữ là do tỉ lệ nghiện rượu ở nam cao hơn nũ , và ở bệnh viêm gan do virus (đặc biệt virus viêm gan B) có những đợt bùng phát thường hay gặp ở nam nhiều hơn.

Trong nghiên cứu của chúng tôi, nguyên nhân gây bệnh lý xơ gan do virus chiếm ưu thế với $\mathrm{HBV} 63,7 \%$ và $\mathrm{HCV}$ là $4,9 \%$, Tải lượng virus HBV-DNA là $5,2 \times 10^{7} \pm 1,5 \times 10^{8}$ copies $/ \mathrm{mL}$, tải lượng virus HCV-DNA là $8,7 \times 10^{6} \pm 1,3 \times 10^{7}$ copies $/ \mathrm{mL}$. Kết quả này tương tự nghiên cứu của Lâm Hoàng Cát Tiên và Hồ Tấn Phát. Ngoài ra nguyên nhân do rượu đơn thuần là 50\%, kết quả này cũng tương đồng với nghiên cứu của tác giả Trần Ánh Tuyết và Lâm Hoàng Cát Tiên, tỷ lệ xơ 
gan do rượu đến $35,9 \%$ và $58,3 \%$ [8], [9]. Trong nghiên cứu của chúng tôi tỷ lệ xơ gan do virus kết hợp rượu là 19,57\%. Theo Atif Zaman nguyên nhẩn xơ gan do virus đơn thuần không cao (33\%), viêm gan do virus C và rượu có tỷ lệ cao nhất [13]. Vì vậy, dù có sự khác nhau vể nguyên nhân gây bệnh trong các nghiên cứu, nhưng nhìn chung các nghiên cứu đều có kết luận những người có bệnh lý gan mạn tính do virus dễ dần đến xơ gan hơn nếu kèm nghiện rượu. Trong nghiên cứu tại Hong Kong, ghi nhận tỷ lệ viêm gan do virus $B$ là $52 \%$ và virus $C$ là $14 \%$. Trong các nghiên cứu tại Châu Âu, tỷ lệ bệnh nhân viêm gan virus $C$ cao hơn viêm gan virus $B$. Từ các kết quả nghiên cứu trên, ta thây rằng nguyên nhân gây bệnh lý chủ mô gan mạn tại các nước thuộc khu vực Đông Nam Á chủ yểu do virus, trong đó chủ yếu là virus viêm gan $B$. Trong khi đó, tại các nước Châu Âu, nguyên nhân chủ yếu là viêm gan virus $C$ và do rượu. Trong nghiên cứu của Foucher, nguyên nhân do nhiễm HCV chiếm đa số, lần lượt là $56 \%, 49 \%$, và $66 \%$ [10]. Trong khi đó, nghiên cứu của M.Ziol toàn bộ là bệnh nhân viêm gan virus $C$ mạn tính. Nguyên nhân do rượu trong nghiên cứu của tác giả Foucher và Ganne và cs [11] cũng khá cao: $12,5 \%$ và $9,6 \%$.

Trong nghiên cứu của chúng tôi các triệu chứng lâm sàng thường gặp là chán ăn, mệt mỏi, lách to, tuần hoàn bàng hệ ở nhiều bệnh nhân, chiếm tỷ lệ $38,2 \%, 46,1 \%, 40,2 \% 40,2 \%$. Điều này cũng phù hợp với những triệu chứng chung xuất hiện ở bệnh nhân xơ gan. Kèm với yếu tố nguy cơ tổn thương gan, giúp các bác sĩ lâm sàng thăm khám bệnh nhân kỹ hơn và kết hợp với các xét nghiệm cận lâm sàng khác giúp phát hiện bệnh sớm. Đến giai đoạn muộn hơn, các triệu chứng này thường gặp ở $100 \%$ bệnh nhân.

Theo nghiên cứu của tác giả trong nước ở bệnh nhân xơ gan có triệu chứng mệt mỏi và rối loạn tiêu hóa rất cao, cao hơn trong nghiên cứu của chúng tôi. Điều này có thể do trong nghiên cứu của chúng tôi, ngoài bệnh nhân xơ gan còn có bệnh nhân bệnh gan mạn tính với nhiêu mức độ xớ hóa khác nhau. Ngoài ra, bệnh nhân còn có biểu hiện ngứa, rối loạn tiêu hoá, gan to. Các triệu chứng này thường không đặc hiệu và có thể gặp trong một số bệnh lý khác, nên dễ bị bỏ sót.

Trong nghiên cứu của chúng tôi, giá trị trung bình của các chỉ số huyết học không có sự khác biệt với các chỉ số của người bình thường ÁST và ALT có thay đổi bất thường. AST $(140,8 \pm 266)$, $\operatorname{ALT}(90,7 \pm 157,1)$. Đây cũng là lý do chính khiến bệnh nhân đi khám bệnh và tầm soát nguyên nhân gây bệnh. Trong nghiên cứu của Ngô Thị Thanh Quýt, $A S T$ và $A L T$ thay đổi, lần lượt là $68,9 \pm 50,2$ và 59,4 \pm 44,7 [7]. Trong nghiên cứu của Lâm Hoàng Cát Tiên, AST tăng cũng là rối loạn cận lâm sàng thường gặp, chiếm tỷ lệ $75 \%$. Như vậy, trong phần lớn các nghiên cứu sự thay đổi giá trị AST và ALT là biểu hiện cận lâm sàng thường gặp sớm trong bệnh lý chủ mô gan mạn tính.

Đa phần bệnh nhân xơ gan là Chid-pugh $A$ là $63,7 \%$, Child-pugh $C$ chiếm tỷ lệ nhỏ nhất với $4,9 \%$. Trong các bệnh nhân này có hơn $1 / 3$ số bệnh nhân có tăng nồng độ AFP, AFP-L3, PIVKA II. Giá trị trung vị của AFP là 5,5; AFP-L3: 0; PIVKA là 20,5; còn ở nhóm bệnh nhân có tăng một trong ba chỉ số AFP, AFP-L3, PIVKA II thì giá trị trung vị này lần lượt là 12,$6 ; 8,1$ và 79,0 tương ứng. Với mức tăng này so với các chỉ số bình thường (dưới 10; dưới 0,5 và dưới 40) thì ngưỡng tăng này không cao. Chúng tôi đã tiến hành thăm dò sâu hơn ở những bệnh nhân này thì trên siêu âm ổ bụng và một số trường hợp được chụp cắt lớp vi tính, cộng hưởng từ, sinh thiết. ở các bệnh nhân có bộ 3 bất thường, trên siêu âm có 51 bệnh nhân khổng có u gan một số bệnh nhân khác có u máu gan, nang gan. Ngoài ra có 1 bệnh nhân có nốt tân tạo rải rác khi được làm thêm MRI (siêu âm không thấy bất thường). Một số bệnh nhân siêu âm thây nang gan, nốt vôi hoá trong gan, gan biến đổi hình thái (teo hạ phân thuỳ IV)... Nhìn chung, các bệnh nhân này không có u hoặc có các tổn thương gan lành tính trên nền gan xơ như u máu, xơ hóa thể nốt khu trú, u nang. Kết quả này khá phù hợp với các nghiên cứu trong và ngoài nước về việc các bệnh nhân xơ gan có thể tăng chỉ số AFP, AFP-L3, PIVKA II, tuy nhiên cần phải theo dõi sát những trường hợp này sau 3-6 tháng để sớm phát hiện các trường hợp ung thư gan nguyên phát.

\section{KẾT LUÂ̂N}

- Tuổi trung bình của nhóm xơ gan là $56,97 \pm 11,59$, tî lệ nam/nữ là 5,8/1.

- Các nguyên nhân gây xơ gan đa phần là nguyên nhân do viêm gan $B$ và rượu

- Các triệu chứng lâm sàng thường gặp trong nhóm xơ gan là chán ăn, mệt mỏi, đau tức hạ sườn phải, tuần hoàn bàng hệ với tỉ lệ $38,2 \%$, $46,1 \%, 40,2 \% 40,2 \%$. Các triệu chứng lâm sàng ít gặp là buồn nôn, ngứa, rối loạn tiêu hoá, gan to

- Giá trị trung bình AST là 140,8 266 và của ALT là $90,7 \pm 157 \mathrm{U} / \mathrm{L}$, cao hơn các giá trị của người bình thường. Tải lượng virus HBV-DNA là $5,2 \times 10^{7} \pm 1,5 \times 10^{8}$ copies/mL, tải lượng virus HCV- 
DNA là $8,7 \times 10^{6} \pm 1,3 \times 10^{7}$ copies $/ \mathrm{mL}$. Có $3 / 32$ bệnh nhân tải lượng HBV dưới ngưỡng, cụ thể: 1 bệnh nhân <58,2 copies/mL, 1 bệnh nhân <116 copies $/ \mathrm{mL}$ và 1 bệnh nhân $<100$ copies $/ \mathrm{mL}$.

- 63,7\% bệnh nhân xơ gan Chid-pugh $A$, Child-pugh (4,9\%).

- Nồng đô trung bình của AFP, AFP-L3, PIVKA

II ở nhóm bệnh nhân xơ gan là $86,8 \mathrm{ng} / \mathrm{mL}$; 6,2\%; 246,98 mAU/mL

\section{TÀl LIỆU THAM KHẢO}

1. Hyuna Sung, Jacques Ferlay, et al (2021) Global cancer statistics 2020: GLOBOCAN estimates of incidence and mortality worldwide for 36 cancers in 185 countries. CA: a cancer journal for clinicians.

2. Lương Ngoc Khuê, Mai Trong Khoa và CS (2020) Hưởng dẩn chẩn đoán và điều trị một số bênh ung bướu. Bô Y tế, tr. 900-935.

3. Rícco G et al. (2018). Impact of etiology of chronic liver disease on hepatocellular carcinoma biomarkers. Cancer Biomark; 21(3):603-612

4. Lim T.S., D.Y. Kim, K.-H. Han, et al (2016).
Combined use of AFP, PIVKA-II, and AFP-L3 as tumor markers enhances diagnostic accuracy for hepatocellular carcinoma in cirrhotic patients. Scandinavian journal of gastroenterology, 51(3), 344-353.

5. Hann H.-W., D. Li, H. Yamada, et al (2014). Usefulness of highly sensitive AFP-L3 and DCP in surveillance for hepatocellular carcinoma in patients with a normal Alpha-Fetoprotein. J Med Microb Diagn, 3(1), 1-6.

6. Ngô Qúy Châu (2020), Bệnh học nội khoa, 4, ed, Vol. 2, Nhà xuất bản Y học, Hà Nội.

7. Ngô Thị Thanh Quýt, Nguyển Phương, Lê Thành Lý, Bùi Hữu Hoàng (2010), "Chẩn đoán mức độ xơ hóa gan bằng phương pháp đo độ đàn hồi gan trên bệnh nhân bệnh gan mạn", Tap chí Y Hoc Thành phổ Hồ Chí Minh, 14(1), tr.161-166.

8. Trân Ânh Tuyết (2006), Khảo sát mối tương quan giữa các yếu tố nguy cơ và giãn tĩnh mạch thực quản trên bệnh nhân xơ gan, Luân văn chuyên khoa cấp II, Đaai học Y-Dược TP.Hố Chí Minh.

9. Lâm Hoàng Cát Tiên (2005), Khảo sát giá trì của phương pháp chẩn đoán không xâm lấn trong xơ gan còn bù, Luận văn bác sĩ nội trú, Đại họ Y Dược TP.Hồ Chí Minh.

\section{MộT SỐ YẾU TỐ LIÊN QUAN ĐẾN MỨC Độ TỰ TIN TRONG GIAO TIẾP CỦA ĐIỀU DƯỠNG VIÊN TAI MộT Số BÊ̂NH VIỆN TỈNH THÁI NGUYÊN VÀ CAO BẰNG NĂM 2021}

\section{Nguyễn Hoàng Long ${ }^{1}$}

\section{TÓM TẮT}

Đăt vấn đề: Mức độ tự tin quyết định tới hiệu quả giao tiếp của điều dưỡng viên. Để nâng cao mức độ tự tin này, việc xác định được các yếu tố liên quan tới nó là rất quan trong. Do đó, nghiên cứu này được tiến hành nhằm tìm hiểu các yếu tố liên quan đến mức độ tự tin của điêu dưỡng viên trong môt số tình huống giao tiếp thường gặp. Đối tượng và phương pháp nghiên cứu: Với thiết kế mổ tả cắt ngang, nghiên cứu được tiến hành trên 125 điều dưỡng tai một số bệnh viện của tỉnh Thái Nguyên và Cao Bằng. Thời gian thực hiện từ tháng 3 đển tháng 4 năm 2021. Đối tượng nghiên cứu được phát vấn thồng qua bộ câu hỏi tự điên về mức độ tự tin khi giao tiếp trong mười một tình huống thường gặp, thang điểm đánh giá gồm 4 mức độ tữ rất không tự tin (0 điểm), bình thường (1 điểm), tự tin (2 điểm), đến rất tự tin (3 điểm). Điểm tự tin trong giao tiếp là điểm tổng của tất cả các câu hỏi, tối đa là 33 điểm. Điểm càng cao thể hiện mức độ tự tin càng lớn. Kết quả: Điểm trung bình mức độ tự tin trong giao tiếp của điều dưỡng viên là $21,49 \pm$

${ }^{1}$ Viện Khoa học Sức khoẻ, Trường Đại học VinUni Chịu trách nhiệm chính: Nguyễn Hoàng Long Email: long.nh@vinuni.edu.vn

Ngày nhận bài: 10.8.2021

Ngày phản biên khoa hoc: 1.10.2021

Ngày duyệt bài: 12.10.2021
3,17. Tỷ lệ điều dưỡng tự tin ở mức trung bình chiếm đa số $(80 \%)$. Bên cạnh đó, $20 \%$ điều dưỡng được đánh giá là tự tin cao, và không có điều dưỡng nào được xếp loại không tự tin trong các tình huống giao tiếp thường gặp được khảo sát. Nghiên cứu cũng không tìm thấy sự khác biệt có ý nghĩa thống kê nào giữa điểm trung bình về mức độ tự tin trong giao tiếp giữa nhóm điều dưỡng từ 35 tuổi trở lên và dưới 35 tuổi, giữa nhóm điều dưỡng làm tại khoa lâm sàng với nhóm làm việc tại phòng ban, cận lâm sàng và khoa khám bênh, giữa nhóm điều dưỡng đã từng được đào tạo và chưa từng được đào tạo vể kỹ năng giao tiếp trước đây, cũng như giữa nhóm điêu dưỡng viên và điều dưỡng trưởng $(p>0,05)$. Kết luận: Mức độ tự tin của điều dưỡng viên trong một số tình huống thường gặp ở mức trung bình. Chưa tìm thấy bằng chứng vê vai trò của các yếu tố gồm tuổi, đơn vị công tác, vị trí công việc, và kinh nghiệm với các khóa đào tạo giao tiếp trước kia với mức độ tự tin trong giao tiếp của điều dưỡng viên.

Tư khóa: Tự tin, Giao tiếp, Điều dưỡng.

\section{SUMMARY}

FACTORS RELATED TO SELF-CONFIDENCE

IN COMMUNICATION AMONG NURSES AT HOSPITALS IN THAI NGUYEN AND CAO BANG PROVINCES, 2021

Background: The level of confidence determines the effectiveness of nurses' communication. To 
increase self-confidence of nurses, it is important to identify factors associated with it. Therefore, this study was conducted to describe some factors related to nurses' confidence in some common communication situations. Methods: A cross-sectional was conducted with 125 nurses from hospitals in Thai Nguyen and Cao Bang province. The data were collected from March to April 2021. The self-administered questionnaire with 11 common communication situations were distributed to all the selected nurses to complete. In this study we apply the Likert scale which consisted of 4 levels, from very unconfident ( 0 points), normal (1 point), confident ( 2 points), to very confident (3 points). Total score is the sum of all questions's score, with the maximum of 33 points. The higher the score, the greater the level of confidence. Results: the sample was composed by 125 nurses, of whom $80 \%$ had a moderate self-confidence in communication, with the average score was $21.49 \pm$ 3.17. In addition, $20 \%$ of nurses were rated as highly confident, and there is no nurse rated as unconfident in common communication situations surveyed. The results showed that no statistically significant differences were found between the average score of different nursing groups, such as: nurse and head nurse, upper and lower 35 years old, working in clinical and paraclinical area, and nurse has been trained and has not been trained on communication before $(p>0,05)$. Conclusion: The level of nurse's confidence in some common situations is average. No evidence was founded for the role of factors including age, work unit, job position, and experience with previous communication training courses on selfconfidence of nurses in communication.

Keywords: Self-confidence, Communication, Nurse.

\section{I. ĐĂT VẤN ĐỀ}

Hoạt động giao tiếp của điều dưỡng viên bị ảnh hưởng bởi nhiều yếu tố như đặc điểm tính cách, tình cảm, nhận thức, điều kiện môi trường xã hội và nền tảng văn hóa của mỗi người [2]. Trong số đó, mức độ tự tin trong giao tiếp là một trong các yếu tố quyết định. Mức độ tự tin ở đầy được hiểu là sự tin tưởing của điều dưỡng trong việc họ có thể, sẵn sàng và xử lý linh hoạt các tình huống giao tiếp thường gặp trong quá trình thực hiện chăm sóc nghề nghiệp của mình [4].

Trên thế giới đã có một số nghiên cứu đề cập đến vai trò của mức độ tự tin trong giao tiếp của điều dưỡng tại các cơ sở khám chữa bệnh. Tổng quan tài liệu của Mark $D$. Hecimovich và Simone E. Volet cho thấy mức độ tự tin trong giao tiếp của điều dưỡng đóng vai trò quan trọng đối với sức khỏe của bệnh nhân [8], ảnh hưởng đáng kể đến kết quả chằm sóc . Nghiên cứu của Parle $M$ (1997) cũng chỉ ra rằng khả năng giao tiếp với người bệnh của bác sĩ và điều dưỡng giúp phát hiện sớm các vấn đề về cảm xúc và ngăn ngừa các biến chứng tâm lý có thể xảy ra, góp phần nâng cao hiệu quả điều trị.
Tuy nhiên, thực tế cho thấy mức độ tự tin của điều dưỡng còn chưa cao. Ở Việt Nam, nghiên cứu của Nguyễn Ngọc Huyền năm 2019 cho thấy, điểm trung bình mức đô tự tin của điều dưỡng thực tập tại bệnh viện TW Thái Nguyên ở mức trung bình $(7,29 \pm 1,24)$. Tỷ lệ phần trăm điều dưỡng tự tin còn thấp, cụ thể trong việc thiết lập mối quan hệ chắt chẽ với người bệnh để họ có thể tìm kiếm sự trợ giúp mà không ngại ngùng là 23,3\%; giải thích về phương pháp điều trị và chăm sóc người bệnh là $21,7 \%$; mức độ tư tin về viêc hỏi người bênh bất kỳ thủ tục nào mà người bệnh không hiểu để hướng dẫn hoặc giúp đõ là $25,8 \%$; và mức độ tự tin trong việc thiết lập mối quan hê tốt trong công việc với điều dưỡng trưởng và các điều dưỡng khác trong khoa là $32,5 \%$ [1].

Một số nghiên cứu đã được tiễn hành để tìm hiểu các yếu tố liên quan tới mức độ tự tin trong giao tiếp của điều dưỡng. Ví dụ, nghiên cứu của Nguyễn Thúy Ly và cộng sự năm 2014 chỉ ra rằng nhóm điều dưỡng có kiến thức, có nhiều kinh nghiệm trong công tác điều dưỡng được đánh giá là tự tin hơn trong việc giao tiếp, trao đổi và chăm sóc toàn diện cho người bệnh [3]. Nghiên cứu của Mojtaba Fattahi Ardakani (2019) và Margaret Rosenzweig (2008) chỉ ra rằng, quá trình đào tạo kỹ năng giao tiếp, sự tự tin của bản thân giúp làm tăng mức độ tự tin của điều dưỡng [9], [7].

Như vấy, mức độ tự tin trong giao tiếp của điều dương là rất quan trọng và cần thiết phải được cải thiện. Tuy vậy, chưa có nhiều nghiên cứu được tiển hành để tìm hiểu các yếu tố liên quan tới mức độ tự tin trong giao tiếp của điều dưỡng. Đăcc biệt, do hoat động giao tiếp bi ảnh hưởng rất lớn bởi các yếu tố về văn hóa nên việc đánh giá mức độ tự tin trong giao tiếp cũng cần được xem xét ở các khu vực văn hóa cu thể. Vì vây, chúng tôi tiến hành nghiên cứu này nhằm "mô tả một số yếu tố liên quan đến mức độ tự tin trong giao tiếp của điều dưỡng viên tại một số bệnh viện của tỉnh Thái Nguyên và Cao Bằng." Hai khu vực được chọn nhằm giúp gợi mơ thông tin cơ bản về nội dung nghiên cứu ở khu vực Miền núi phía Bắc, nơi có các nét văn hóa, xã hội riêng biệt. Kết quả của nghiên cứu sẽ giúp các nhà quản lý bênh viên có những giải pháp nhằm cải thiện chất lượng giao tiếp của điều dưỡng ở khu vực này.

\section{II. ĐỐI TƯỢNG VÀ PHƯƠNG PHÁP NGHIÊN CỨU \\ 2.1 Thiết kế nghiên cứu: Mô tả cắt ngang 2.2 Địa điểm, thời gian: Nghiên cứu chọn}


chủ đích 06 bệnh viện thuộc các tuyến khác nhau tại tỉnh Thái Nguyên (Bệnh viện $A$, Bệnh viện Quốc tế Thái Nguyên, BV Lao, Bệnh viện PHCN, Bệnh viện Đại học $Y$ Thái Nguyên, BV 91) và 01 Bệnh viện Đa khoa tỉnh Cao Bằng. Đây là các bệnh viện tham gia chương trình đào tạo kỹ năng giao tiếp trong khuôn khổ chương trình chỉ đạo tuyến của bệnh viện Trung ương Thái Nguyên. Số liệu được thu thập từ tháng 3 đến tháng 4 năm 2021.

2.3 Đối tượng nghiên cứu: Điều dưỡng làm việc tại các khoa phòng khác nhau của bệnh viện tham gia nghiên cứu.

2.4 Cỡ mẫu và phương pháp chọn mẫu: Chọn thuân tiện, tất cả 125 điều dưỡng viên tham gia khóa đào tạo kỹ năng giao tiếp được mời tham gia nghiên cứu và đều chấp thuận.

2.5 Phương pháp thu thập thông tin: Nhóm nghiên cứu thực hiện phát vấn đối tượng, sử dụng bộ công cụ đánh giá mức độ tự tin trong giao tiếp của điều dưỡng trước khi đối tượng nghiên cứu bắt đầu buổi đầu tiên của đợt đào tao.

2.6 Bộ công cụ và thang đo: Bộ công cụ được xây dựng dựa trên các y văn về giao tiếp giữa điều dưỡng với người bệnh [5], có tham khảo ý kiến chuyên gia và chỉnh sửa phù hợp với thực tế. Mức độ tự tin trong giao tiếp của điều dưỡng được đánh giá theo thang điểm liker 4 mức độ, từ rất không tự tin ( 0 điểm), bình thường (1 điểm), tự tin (2 điểm), và rất tự tin (3 điểm), thông qua 11 tình huống thường gặp, ví dụ như giới thiệu bản thân, giải thích về kỹ thuật sẽ thực hiện, thể hiện sự đồng cảm, thể hiện sự không đồng tình với người khác. Điểm tự tin là điểm tổng của 11 câu hỏi, thay đổi từ 0 đến 33 điểm. Điều dưỡng được đánh giá ở ba mức là "tự tin cao", "tự tin trung bình" và "không tự tin" khi tổng điểm lần lượt là 22-33, 11-22 và 0-11.

2.7 Phân tích số liệu: Số liêu được tính toán tỷ lệ \%, giá trị trung bình và độ lệch chuẩn để mô tả đặc điểm và mức độ tự tin của đối tượng nghiên cứu. Sử dụng kiểm định student (ttest) để so sánh sự khác biệt giữa các giá trị trung bình.

2.8 Đạo đức nghiên cứu: Nghiên cứu đã được thông qua hội đồng đạo đức nghiên cứu y sinh học của Bệnh viện Trung ương Thái Nguyên.

\section{KẾT QUẢ NGHIÊN CứU}

Bảng 1. Đặc điểm chung của điều dướng tại các bệnh viện tỉnh Thái Nguyên và Cao Bằng năm 2021 ( $n=125)$

\begin{tabular}{|l|l|l|} 
Đặc điếm & $\mathbf{n}$ & $\%$ \\
\hline
\end{tabular}

\begin{tabular}{|c|c|c|c|}
\hline \multirow{2}{*}{ Giới } & Nam & 8 & 6,4 \\
\cline { 2 - 4 } & Nữ & 117 & 93,6 \\
\hline \multirow{2}{*}{ Tuổi } & $<35$ tuối & 51 & 40,8 \\
\cline { 2 - 4 } & $\geq 35$ tuối & 74 & 59,2 \\
\hline \multirow{2}{*}{$\begin{array}{c}\text { Đơn vì } \\
\text { công tác }\end{array}$} & Khoa lâm sàng & 72 & 57,6 \\
\cline { 2 - 4 } & $\begin{array}{c}\text { Phòng ban, CLS, } \\
\text { KKB }\end{array}$ & 53 & 42,4 \\
\hline \multirow{2}{*}{$\begin{array}{c}\text { Trình đồ } \\
\text { chuyên } \\
\text { môn }\end{array}$} & Sau đại họC & 3 & 2,4 \\
\cline { 2 - 4 } & Đại học/cao đăng & 113 & 90,4 \\
\cline { 2 - 4 } & Trung họC & 9 & 7,2 \\
\hline \multirow{2}{*}{ môn }
\end{tabular}

Kết quả nghiên cứu cho thấy tỷ lệ điều dưỡng là nữ chiếm đa số $(93,6 \%)$, với độ tuổi trung bình là $35,7( \pm 6,02)$ tuổi, trong đó số tuổi thấp nhất là 21 , và cao nhất là 53 tuổi. Thời gian công tác trung bình là $12,2( \pm 5,8)$ năm. Số điều dưỡng công tác tại khối lâm sàng cao hơn khối cận lâm sàng/ phòng ban, với tỷ lệ \% lần lượt là $57,6 \%$ và $42,4 \%$. Đa số đối tượng nghiên cứu có trình độ Đại học, Cao đẳng (90,4\%).

Bảng 2. Mức độ tứ tîn trong giao tiêp của điều dướng tại các bệnh viện tỉnh Thái Nguyên và Cao Bằng năm 2021

\begin{tabular}{|c|c|c|c|}
\hline Mức độ tự tin & $\mathbf{n}$ & $\mathbf{\%}$ & $\mathbf{x} \pm \mathbf{~ S D}$ \\
\hline Tự tin cao & 25 & 20,0 & $26,20 \pm 1,83$ \\
\hline Tự tị trung bình & 100 & 80,0 & $20,31 \pm 3,06$ \\
\hline Không tự tin & 0 & 0 & 0 \\
\hline Tống & $\mathbf{1 2 5}$ & $\mathbf{1 0 0 \%}$ & $\mathbf{2 1 , 4 9} \pm \mathbf{3 , 1 7}$ \\
\hline
\end{tabular}

Kết quả từ bảng trên cho thấy điểm trung bình mức độ tự tin của điều dưỡng khi giao tiếp là $21,49 \pm 3,17$. Tỷ lệ điều dưỡng có mức độ tự tin trung bình khi giao tiếp chiếm đa số $(80 \%)$. Chỉ có $20 \%$ điều dưỡng được đánh giá là có tự tin, và không có điều dưỡng nào cảm thấy không tự tin trong các tình huống giao tiếp thường gặp.

Bảng 3. Môt số yếu tố liên quan đêén mức độ tư tîn trong giao tiếp của điều dướng tại các bệnh viện tỉnh Thái Nguyên và Cao Bằng năm 2021 ( $n=125)$

\begin{tabular}{|c|c|c|c|}
\hline & $\%$ & $\stackrel{\sqrt{x}}{(\operatorname{Min}-\operatorname{Max})}$ & $\begin{array}{c}P \\
(t-\text { test })\end{array}$ \\
\hline \multicolumn{4}{|c|}{ Nhóm tuối } \\
\hline$<35$ tuối & 40,8 & $21,1(15-31)$ & \multirow{2}{*}{0,307} \\
\hline$\geq 35$ tuối & 59,2 & $21,7(14-33)$ & \\
\hline \multicolumn{4}{|c|}{ Khoa phòng công tác } \\
\hline Cận lâm sàng & 42,4 & $21,5(14-33)$ & \multirow{2}{*}{0,904} \\
\hline Khoa lâm sàng & 57,6 & $21,5(15-33)$ & \\
\hline \multicolumn{4}{|c|}{ Chức vụ hiện tại } \\
\hline Điều dưỡng viên & 79,2 & $21,2(14-31)$ & \multirow[b]{2}{*}{0,058} \\
\hline $\begin{array}{c}\text { ĐD trưởng } \\
\text { nhóm/khoa/BV }\end{array}$ & 20,8 & $\begin{array}{c}22,5 \\
(18-33)\end{array}$ & \\
\hline \multicolumn{4}{|c|}{ Được đào tạo KNGT } \\
\hline Đã từng & 50,4 & $22(14-33)$ & \multirow{2}{*}{0,099} \\
\hline Chưa từng & 49,6 & $21(15-31)$ & \\
\hline
\end{tabular}


\begin{tabular}{|l|l|l|l|}
\hline Dưới 50 & 59,2 & $21,5(15-33)$ & \multirow{2}{*}{0,995}
\end{tabular}

Kết quả nghiên cứu cho thấy có sự khác nhau giữa tỷ lệ \% và điểm trung bình mức độ tự tin khi giao tiếp giữa nhóm điều dưỡng trên và dưới 35 tuổi, giữa nhóm điều dưỡng làm tại khoa lâm sàng và khoa cận lâm sàng, giữa nhóm điều dưỡng viên và điều dưỡng trưởng cũng như giữa nhóm điều dưỡng đã từng được đào tạo và chưa từng được đào tạo về kỹ năng giao tiếp trước đây. Tuy nhiên, sự khác biệt này không có ý nghĩa thống kê với p>0,05.

\section{BÀN LUẬN}

Kết quả của nghiên cứu cho thấy tỷ lệ điều dưỡng tự đánh giá sự tự tin của mình ở mức trung bình là $80 \%$, và không có điều dưỡng nào cảm thấy không tự tin khi giao tiếp. Điểm trung bình mức độ tự tin trong giao tiếp của điều dưỡng là 21,49 $\pm 3,17$ điểm. Với tổng điểm tối đa 33 của thang đo, ngưỡng điểm này được đánh giá ở mức trung bình. Kết quả này cũng tương đồng với nghiên cứu của Nguyễn Ngọc Huyền năm 2019 trên các sinh viên thực tập tại bệnh viện Thái Nguyên, cho thấy mức độ tự tin trong giao tiếp của điều dưỡng cũng ở mức trung bình. Một số tình huống giao tiếp thường gặp mà điều dương chưa thực sự tự tin bao gồm: Thiết lập mối quan hê chặt chẽ với người bệnh để họ có thể tìm kiếm sự trợ giúp mà không ngại ngùng; Thiết lập mối quan hệ tốt trong công việc với điều dưỡng trưởng và các điều dưỡng khác trong khoa. Kết quả nghiên cứu cho thấy, điều dưỡng viên cần được giúp đõ để nâng cao sự tự tin trong giao tiếp.

Nghiên cứu này không tìm thấy sự khác biệt có ý nghĩa thống kê về mức đô tự tin trong giao tiếp giữa nhóm điều dưỡng từ 35 tuổi trở lên và dưới 35 tuổi. Theo quan niệm thông thường, người càng nhiều tuổi càng có nhiều kinh nghiệm và tự tin hơn khi giao tiếp. Tuy nhiên, các yêu cầu về kỹ năng giao tiếp trong chuẩn năng lực của điều dưỡng càng ngày càng cao, điều này có thể làm cho các điều dưỡng lớn tuổi chưa đáp ứng được bằng những người trẻ, vì vậy họ có thể sẽ không được tự tin khi giao tiếp so với các điều dưỡng trẻ tuổi hơn. Kết quả này cũng gợi ý rằng không chỉ điều dưỡng trẻ, mới vào nghề mà cả các đối tượng đã có kinh nghiệm cũng cần được quan tâm, rèn luyện nâng cao mức độ tự tin trong giao tiếp.

Ngoài ra, kết quả nghiên cứu cũng không thấy có sự khác biệt một cách có ý nghĩa giữa nhóm điều dưỡng viên với nhóm là điều dưỡng trưởng khoa. Điều này rất đáng quan tâm. Lý do là vì phạm vi và nội dung giao tiếp của đối tượng điều dưỡng làm quản lý rộng hơn rất nhiều so với đối tượng khác. Do đó, họ cần có kỹ năng và mức độ tự tin trong giao tiếp cao hơn. Việc nâng cao kỹ năng giao tiếp cho điều dưỡng trưởng đã được khuyến nghị rất nhiều [5],[6]. Kết quả nghiên cứu này một lần nữa nhấn mạnh yêu câu thiết yếu của việc hỗ trợ, đào tạo về giao tiếp cho các điều dưỡng làm công tác quản lý.

Trong nghiên cứu này, kết quả cũng cho thây không có sự khác biệt có ý nghĩa thống kê giữa nhóm điều dưỡng đã từng được đào tạo và chưa từng được đào tạo về kỹ năng giao tiếp trước đây. Kết quả này rất đáng quan tâm vì nó khác biêt so với các kết quả đã được công bố, thậm chí có vẻ trái ngược với lý thuyểt về tác dụng của hoạt động đào tạo. Theo Mojtaba Fattahi Ardakani và cộng sự, quá trình đào tạo kỹ năng giao tiếp giúp làm tăng mức độ tự tin của điều dưỡng một cách có ý nghĩa thống kê $(95 \% \mathrm{CI}$ : $0,311-0,699, p<0,001)[9]$. Nghiên cứu của Margaret Rosenzweig cũng chỉ ra rằng sự tự tin của sinh viên điều dưỡng khi bắt đầu các cuộc trò chuyện khó khăn đã tăng lên đáng kể cả ngay lập tức $(p<0,001)$ và 4 tháng sau $(p=$ $0,001)$ khi tham gia chương trình đào tạo mô phỏng về giao tiếp [7]. Có thể có nhiều cách lý giải cho sự khác biệt này. Thứ nhất, cõ̃ của mẫu nghiên cứu này có thể chưa đủ lớn để giúp ghi nhận sự khác biệt. Thứ hai, quan trọng hơn, các chương trình đào tao kỹ năng giao tiếp có thể chưa thực sự hiệu quả, chưa tạo ra sự khác biệt giữa người đã tham gia đào tạo và người chưa được tham gia đào tạo. Thứ ba, các lý thuyết về khoa hoc hành vi cho thấy đào tạo chỉ là một trong các phương cách để xây dựng sự tự tin. Vì vậy, tác dụng thực sự của hoạt động đào tạo trong việc giúp điểu dưỡng tự tin hớn trong giao tiếp cần tiếp tục được tìm hiểu bởi các nghiên cứu khác trong tương lai.

\section{KẾT LUẦN}

Nghiên cứu trên 125 điều dưỡng tại một số bệnh viện tỉnh Thái Nguyên và Cao Bằng năm 2021 cho thấy $80 \%$ điêu dưỡng tự tin khi giao tiếp ở mức trung bình, với điểm trung bình mức độ tự tin là $21,49 \pm 3,17$. Không tìm thây sự khác biệt có ý nghĩa thống kê về mức độ tự tin trong giao tiếp của điều dưỡng theo nhóm tuổi trên và dưới 35 tuổi, theo chức vụ điều dưỡng trưởng và điều dưỡng viên, giữa nhóm điều dưỡng làm việc tại khoa lâm sàng với phòng ban, cận lâm sàng, và giữa nhóm điều dưỡng đã được 
đào tạo về kỹ năng giao tiếp với nhóm chưa được đào tạo.

\section{TÀI LIÊU THAM KHẢO}

1. Nguyễn Ngọc Huyên (2019). Sự tự tin trong thực hành kỹ năng lâm sàng của sinh viên điêu dưỡng chính quy tại Bệnh viện trung ương Thái Nguyên năm 2019. Ṫạp chí Khơa học và công nghế Đại học Thái Nguyên, 225(01), 47-52.

2. Lương Ngọc Khuê (2012). Tăng cường năng lực quản lý điêu dưỡng. Bộ Y Tế.

3. Nguyến Thúy Ly, Yvonne Osborne và Patsty Yates (2014). Kiến thức, thái độ và sự tự tin trong thực hanh chăm sóc giảm nhẹ của điêu dưỡng tại một số bệnh viện chuyên khoa Ung bướu Hà Nôii. International journal of palliative nursing, 20(9), 448.

4. Bandura A (1977). Self-confidence: toward a unifying theory of behavioral change. Psychological Review, 84(2), 191

5. Chia-Hui W, Kathryn A, Nai-Wen K (2016). The Role of Head Nurse on Communication: A
Social Network Approach. International Journal of Future Computer and Communication, Vol. 5, No. 1, February 2016.

6. Ika C, Novieastari E, Nuraini T (2019). The role of a head nurses in preventing interdisciplinary conflicts. Enferm Clin; 29(S2): 123-127.

7. Margaret Rosenzweig et all (2008). Patient communication simulation laboratory for students in an acute care nurse practitioner program. American Journal Of Critical Care, 17(4), 364-372.

8. Mark D. Hecimovich, MSc, DC, ATC and Simone E. Volet, PhD (2009), Importance of Building Confidence in Patient Communication and Clinical Skills Among Chiropractic Students. The Journal of Chiropractic Education; 23(2): 151-164.

9. Mojtaba Fattahi Ardakani, Mohammad Ali Morowati Sharifabad, Mohammad Amin Bahrami, Amin Salehi Abargouei4 (2019). The effect of communication skills training on the self-confidence of nurses: a systematic review and meta-analysis study. Bali Medical Journal, 8(1), 144-152. P-ISSN.2089-1180, E-ISSN.2302-2914 144

\section{KHẢO SÁT VIÊC SỬ DỰG THUỐC GIẢM ĐAU VÀ NHỮNG RÀO CẢN TRONG QUẢN LÝ ĐAU UNG THƯ TRÊN BỆNH NHÂN ĐIỀU TR! TẠI BỆNH VIỆN K2}

\section{Bùi Thanh Loan', Đoàn Lực ${ }^{2}$ Phan Thị Quỳnh Nga ${ }^{3}$, Quách Phụng Linh ${ }^{3}$, Nguyễn Tứ Sơn ${ }^{1}$ \\ nhân trong quản lý đau ung thư bao gồm: không nắm được hướng dẫn dùng thuốc, quan niệm rằng thuốc giảm đau chỉ nên uống khi đau, cố gắng chịu đau, sợ tác dụng phụ và sợ dung nạp thuốc. Cần can thiệp để cải thiện vấn đề tuân thủ dùng thuốc và hạn chế các rào cản từ bệnh nhân trong quản lý đau ung thư.}

\section{TÓM TẮT}

Mục tiêu: Khảo sát việc kê đơn sử dụng thuốc giảm đau, sự tuân thủ dùng thuốc giảm đau và những rào cản trên bệnh nhân trong quản lý đau ung thư. Phương pháp: Nghiên cứu cắt ngang, sử dung bố câu hỏi thông qua hình thức phỏng vấn trực tiểp hoặc qua điên thoai. Kết quả: Tuổi trung bình của 46 bênh nhân là 57,5 ; ung thư phế quản phổi là loại ung thư phổ biến nhất. Phần lớn bênh nhân còn đau mức độ trung bình $(63 \%)$ và nặng $(21,7 \%)$. Phác đồ giảm đau phổ biến nhất được duy trì là tramadol + paracetamol. Tỷ lệ không tuân thủ dùng thuốc giảm đau là $65,2 \% ; 19,6 \%$ bệnh nhân không mô tả đúng hướng dẫn dùng thuốc của cán bộ y tế.Từ 47,5\% đến 100\% bệnh nhân đồng ý hoàn toàn với các vấn đề: như thuốc giảm đau chỉ nên dùng khi đau, đau là diến biến tự nhiên của bệnh cân phải chịu đựng, sợ tác dụng phụ và sợ thuốc giảm đau sẽ mất dần tác dụng. Kết luận: Gần $2 / 3$ bệnh nhân không tuân thủ việc sử dụng thuốc giảm đau; những rào cản chính từ bệnh

\footnotetext{
${ }^{1}$ Trường Đại hoc Dước Hà Nôii

${ }^{2}$ Trung tâm Chăm Sóc Giảm Nhẹ, Bệnh viện K ${ }^{3}$ Bênh viênK

Chịu trách nhiệm chính: Bùi Thanh Loan

Email: buithanhloandkh@gmail.com

Ngày nhận bài: 9.8.2021

Ngày phản biên khoa hoc: 4.10 .2021

Ngày duyệt bài: 14.10.2021
}

Tư khóa: Quản lý đau ung thư, rào cản, tuân thủ điều trị, bệnh viện $\mathrm{K}$.

\section{SUMMARY \\ THE USE OF ANALGESICS AND BARRIERS TO CANCER PAIN MANAGEMENT IN K2 HOSPITAL}

Objectives: To investigate analgesic prescribing, pain medication adherence and patient barriers to cancer pain management. Methods: Across-sectional studywas conducted, patients wereface-to-face interviewedor via telephonewith a questionnaire. Results: 46 patientsparticipated the study (mean age: 57.5). Lungcancer wasthe most common cancer. Most patients weresuffering moderate pain $(63 \%)$ and severe pain $(21.7 \%)$. The most common analgesic regimen was tramadol+paracetamol. The rate of patients not adherenceis $65.2 \% ; 19.6 \%$ of patients did not know the instructions of using analgesics. From $47.5 \%$ to $100 \%$ of patients agree with issues such as pain medication should only be used when pain, pain is a natural course of the disease that must be endured, fear of side effects and fear of pain medication will gradually lose its effect. Conclusion: 
Nearly two-third of patients in the study did not adhere with the use of analgesics; and major patient barriers to cancer pain management include: failure to understand dosing instructions, the notion that pain medications should only be taken when in pain, endure the pain without treatment, fear of side effects, and fear of tolerance. Interventions are needed to improve medication adherence and reduce barriers to cancer pain management.

Key words: Cancer pain management, barriers, adherence, $\mathrm{K}$ hospital.

\section{I. ĐẶT VẤN ĐỀ}

Đau là một trong những triệu chứng phổ biến và đáng sợ nhất xảy ra ở bệnh nhân ung thư, gây ảnh hưởng nghiêm trọng đến chất lượng cuộc sống và là một yếu tố dự báo khả nẳng sống của bệnh nhẩn[5]. Vì vậy, giảm đau đã được xác định là một trong những nhiệm vụ quan trong nhất trong điêu trị. Mặc dù đã có nhiều bằng chứng về hiệu quả giảm đau, một lượng lớn bệnh nhân ung thư trên thế giới vẫn chưa được giảm đau đầy đủ. Đồng thời, thiếu tuân thủ điều trịlà một trong những nguyên nhân quan trọng dẫn đên thất bại hoặc không đạt mục tiêu quản lý đau. Nguyên nhân không tuẩn thủ sử dụng thuốc giảm đau đến từ những rào cản trong quản lý đau của bệnh nhân như sợ nghiện thuốc, lo ngại về tác dụng phụ, lo ngại về sự dung nạp thuốc,... Nhằm có cái nhìn về sử dụng thuốc giảm đau và rào cản trong quản lý đau ung thư', nghiên cứu được tiến hành với mục tiêu khảo sát việc kê đơn thuốc giảm đau, tuẩn thủ dùng thuốcvà những rào cản của bệnh nhân trong quản lý đau ung thư đang điều trị tại Trung tâm Chăm Sóc Giảm Nhẹ - Bệnh viện K.

\section{II. ĐỐI TƯợNG VÀ PHƯƠ'NG PHÁP NGHIÊN CỨU}

Đối tượng nghiên cứu: Bệnh nhânung thư từ 18 tuổi trở lên nhập viện điêuu trị hoặc các bệnh nhân ngoại trú tái khám tại Trung tâm Chăm Sóc Giảm Nhe - Bệnh viện K trong khoảng thời gian 1/4/2021 đến 15/9/2021 đông ý tham gia nghiên cứu. Tiêu chuẩn lựa chọn là các bệnh nhân có đau liên quan đên ung thư và đã được kê đơn điêu trị đau bằng bất kỳ 1 loại thuốc giảm đau nào trong vòng ít nhất 7 ngày. Loại trừ các bệnh nhân suy giảm nhận thức, bệnh nhân không thể giao tiếp bằng î̛̀i, các bệnh nhân đang gặp tình trạng cấp cứu, bệnh nhân mới phẫu thuật trong vòng 1 tháng trước đó.

\section{Phương pháp nghiên cứu:}

* Thiết kế nghiên cứu: Nghiên cứucắt ngang

* Thu thập số liệu: Các bệnh nhân được phỏng vẫn trực tiếp hoặc qua điện thoại sử dụng bộ câuu hỏi và hồi cứu dữ liệu từ hồ sơ bệnh án của bệnh nhân lưu tại bệnh viện $\mathrm{K}$.
* Công cụ phỏng vấn là bộ câu hỏi do nhóm nghiên cứu thiết kế. Trong đó, đánh giá đau dựa trên công cụ đánh giá đau BPI được trích từ tài liệu "Hướng dẫn chăm sóc giảm nhẹ đôii với người bệnh ung thư và AIDS" - Bộ Y Tế (2006)[1]. Bộ câuu hỏi phỏng vấn rào cản của bệnh nhân được thiết kế dựa trên các rào cản đã được công bố trong các nghiên cứu tương tự.

* Quy ước trong nghiên cứu:

- Mức độ đau của bệnh nhân được xác định dựa trên điểm đau nă̆ng nhất trong 24 giờ trước với quy ướctheo hướng dẫn của NCCN - 2020 (National Comprehensive Cancer Network) [3]:

- Đau nhe: điểm đau từ 1-3

- Đau trung bình: điểm đau từ 4-7

- Đau nặng: điểm đau 8-10

- Liều lượng thuốc giảm đau được tra cứu theo hướng dẩn giảm đau trong ung thư của WHO (2018) và NCCN $(2020)[3,6]$.

- Bệnh nhân được xác định biết cách dùng thuốc đúng nếu mồ tả đúng hướng dẫn trong đơn thuốc của Bác sĩ khi được đề nghị mô tả lại cách dùng thuốc cán bộ y tễ đã hướng dẫn họ.

- Bệnh nhân được xác định không tuân thủ dùng thuốc giảm đau nếu cách dùng thuốc của họ khác với hướng dẫn được Bác sĩ kê đơn.

* Xứ lý số liệu: Số liệu được xử lý bằng Excel 2016 và R 3.6.3

\section{KẾT QUẢ NGHIÊN CỨU}

Đặc điểm mẫu nghiên cứu. Tổng số 46 bệnh nhân đủ tiêu chuẩn đồng ý ý tham gia nghiên cứu. Tuổi trung bình của mẫu nghiên cứu là 57,5 , tỷ lệ nam chiểm $69,6 \%$ gấp hơn 2 lần so với nữ 30,4\%. Gần một nửa mấu nghiên cứu là các bệnh nhân ung thư phế quản - phổi $(45,7 \%)$, tiếp theo sau là các loại ung thư thực quản $10,9 \%$, ung thư vú $6,3 \%$, các loại ung thư khác chiếm tỷ lệ < $5 \%$ gồm: ung thư dạ dày, trực tràng, hạ hầu, cổ tử cung, tiên liệt tuyễn, buồng trứng, gan, đại tràng, cột sống, lách, khẩu cái, ống tai ngoài, lympho. Phần lớn bệnh nhân ung thư giai đoạn 4 (91,3\%); 82,6\% bệnh nhân có di căn; 41,3\% mẫu nghiên cứu đang điều trị ung thư bằng biện pháp hóa trị. Sau khi điều trị bằng phác đồ giảm đau ít nhất 7 ngày mức độ đau của bệnh nhân trong mẫu nghiên cứu ghi nhận được gồm đau nặng $21,7 \%$, đau trung bình $63 \%$, đau nhe $15,2 \%$.

Các phác đồ giảm đau được kê đơn. Phác đồ được sử dụng phổ biến nhất trong nghiên cứu là Tramadol + paracetamol \pm thuốc hố trợ giảm đau (64,7\%).Trong đó, 15,2\% bệnh nhân đau nặng đang được duy trì với phác đồ này. Các opioid mạnh như morphin, fentanyl đang 
được sử dụng duy trì cho 4 (8,8\%) bệnh nhân.

Tất cả các thuốc giảm đau và hỗ trợ giảm đau đều được sử dụng với chế độ liều trong giới hạn cho phép.

\section{Bảng 1. Các phác đồ giảm đau bệnh nhân đang duy trì}

\begin{tabular}{|c|c|c|c|c|c|c|}
\hline \multirow[b]{2}{*}{$\begin{array}{c}\text { Mức độ } \\
\text { đau }\end{array}$} & \multicolumn{6}{|c|}{ Các phác đồ giảm đau, $\mathrm{N}=46, \mathrm{n}(\%)$} \\
\hline & $\begin{array}{c}\text { Tramadol }+ \\
\text { paracetamol } \pm \\
\text { THTGE* }^{*}\end{array}$ & $\begin{array}{c}\text { Codein }+ \\
\text { paracetamol } \pm \\
\text { THTGE* }^{*}\end{array}$ & $\begin{array}{c}\text { Tramadol }+ \\
\text { paracetamol }+ \\
\text { diclofenac } \pm \\
\text { THTGĐ* }^{*}\end{array}$ & $\begin{array}{l}\text { Morphin } \pm \\
\text { THTGĐ* }^{*}\end{array}$ & $\begin{array}{c}\text { Morphin+ } \\
\text { paracetamol }+ \\
\text { tramadol } \pm \\
\text { THTGĐ* }^{*}\end{array}$ & $\begin{array}{c}\text { Fentanyl }+ \\
\text { morphin }+ \\
\text { codein }+ \\
\text { ibuprofen }+ \\
\text { paracetamol }+ \\
\text { THTGĐ }\end{array}$ \\
\hline Đau nhẹ & $4(8,7 \%)$ & $3(6,5 \%)$ & $0(0 \%)$ & $0(0 \%)$ & $0(0 \%)$ & $0(0 \%)$ \\
\hline $\begin{array}{l}\text { Đau trung } \\
\text { bình }\end{array}$ & $20(43,5 \%)$ & $7(15,2 \%)$ & $1(2,2 \%)$ & $1(2,2 \%)$ & $0(0 \%)$ & $0(0 \%)$ \\
\hline Đau nặng & $7(1$ & $0(0 \%)$ & $0 \%)$ & 12 & 1( & $\%)$ \\
\hline Tống số (46) & $31(64,7 \%)$ & $10(21,7 \%)$ & $1(2,2 \%)$ & $2(4,4 \%)$ & $1(2,2 \%)$ & $1(2,2 \%)$ \\
\hline
\end{tabular}

*THTGĐ: Thuốc hỗ trợ giảm đau

Tuân thủ dùng thuốc giảm đau và hỗ trợ giảm đau. Có $65,2 \%$ bệnh nhân không tuân thủ việc sử dụng phác đồ giảm đau như được kê đớn. Trong đó, phổ biến nhất là các bệnh nhân thay đổi liều chiếm 37,0\%. Có 15,2\% bệnh nhân chỉ dùng thuốc khi đau nhiều; $15,2 \%$ bệnh nhân có dùng thêm các thuốc giảm đau khác, 10,9\% bênh nhân bỏ hoàn toàn thuốc giảm đau mặc dù vẩn còn đau.

Bảng 3. Tuân thủ dùng thuốc giảm đau và hố trợ giảm đau

\begin{tabular}{|c|c|}
\hline Tiêu chí & $\begin{array}{c}\text { Số beênh } \mathbf{n h a ̂ n} \\
(\mathbf{n}, \mathbf{\%}) \mathbf{N}=\mathbf{4 6}\end{array}$ \\
\hline Tuân thủ dùng thuốc giảm đau & $16(34,8 \%)$ \\
\hline $\begin{array}{c}\text { Không tuân thủ dùng thuốc } \\
\text { giảm đau }\end{array}$ & $30(65,2 \%)$ \\
\hline - Thay đối liều & $17(37,0 \%)$ \\
\hline - Chỉ dùng khi đau & $7(15,2 \%)$ \\
\hline - Thêm thuốc & $7(15,2 \%)$ \\
\hline - Bỏ hoàn toàn & $5(10,9 \%)$ \\
\hline - Chì dùng thuốc hồ trợ & $1(2,2 \%)$ \\
\hline
\end{tabular}

\section{giảm đau}

- Bớt thuốc giảm đau $1(2,2 \%)$

Những rào cản trong quản lý đau ung thư ở bềnh nhân. Có $19,6 \%$ bênh nhân đã không mồ tả đúng cách dùng thuốc được cán bộ y tế hướng dẫn và tất cả các bệnh nhân này đều sử dung thuốc với chế đô liều khác với đơn kê. Đáng chú ý, hầu hết các bênh nhân đồng ý rằng thuốc giảm đau chỉ nên dùng khi đau, không nên dùng liên tục kể cả khi có đau (100\%) và đau là diễn biến tự nhiên của bệnh cần phải chịu đựng (90\%). Khoảng một nửa số bệnh nhân đồng ý về các rào cản như sợ tác dụng phụ của thuốc $(62,5 \%)$, sợ dung nạp thuốc $(47,5 \%)$, quan niệm rằng đau tằng lên là bệnh tình nặng hơn $(50 \%)$. Sợ nghiện thuốc giảm đau, hoài nghi về tác dụng của thuốc, mong muốn trở thành "bệnh nhân tốt" ít phàn nàn về đau và sợ bác sĩ phân tâm viêc điều trị khối u không phải là những rào cản chính được xác định trong nghiên cứu.

Bảng 3. Những rào cản trong quản lý đau ung thư ở bệnh nhân

\begin{tabular}{|c|c|c|c|}
\hline Tiêu chí & \multicolumn{3}{|c|}{ Số bệnh nhân n (\%) } \\
\hline Mô tả cách dùng các thuốc được kê đơn, N=46 & $\frac{\text { Mô tả đún }}{37(80,4 \%)}$ & $\begin{array}{r}\text { Không n } \\
9(1\end{array}$ & $\begin{array}{l}\text { 1ô tả đúng } \\
9,6 \%)\end{array}$ \\
\hline Các rào cản & Đông ý & $\begin{array}{l}\text { Không chắc } \\
\text { chắn }\end{array}$ & $\begin{array}{l}\text { Không } \\
\text { đồng ý }\end{array}$ \\
\hline $\begin{array}{c}\text { Thuốc giảm đauchỉ nên uống khi đau, không nên dùng } \\
\text { liên tục kể cả khi có đau }\end{array}$ & $40(100 \%)$ & $0(0 \%)$ & $0(0 \%)$ \\
\hline Đau là diền biến tự nhiên của bệnh cần phải chịu đựng & $\%)$ & $0\left(0^{\circ}\right.$ & $4(10 \%)$ \\
\hline Ông/bà lo lắng về tác dung phu của thuốc & $25(62,5 \%)$ & $4(10 \%)$ & $11(27,5 \%)$ \\
\hline Lo lắng rằng đau tăng lên là bệnh đang nặng hơn & $20(50 \%)$ & $9(22,5 \%)$ & $11(27,5 \%)$ \\
\hline $\begin{array}{c}\text { Ông/bà lo lắng thuốc giảm đau sẽ giảm dần tác dụng } \\
\text { nên để dành để dùng khi bệnh nặng hơn }\end{array}$ & $5 \%)$ & $14(35 \%)$ & $7(17,5 \%)$ \\
\hline Ông/bà S & $\%)$ & $9(22,5 \%)$ & $7,5 \%)$ \\
\hline Thuốc giảm đau không thức sư gic & $5(12,5 \%)$ & $9(22,5 \%)$ & $26(65 \%)$ \\
\hline
\end{tabular}




\begin{tabular}{|c|c|c|c|}
\hline có dùng thuốc cơn đau cũng không hết & & & \\
\hline Lo ngại bác sĩ cảm thấy phiền khi phản hồi về đau & $3(7,5 \%)$ & $4(10 \%)$ & $33(82,5 \%)$ \\
\hline $\begin{array}{c}\text { Sợ bác sĩ phân tâm việc điều trị khối u của mình nễu } \\
\text { phàn nàn nhiều về cơn đau }\end{array}$ & $1(2,5 \%)$ & $\mathbf{3}(10 \%)$ & $35(87,5 \%)$ \\
\hline
\end{tabular}

\section{BÀN LUẬN}

\section{Việc sử dụng thuốc giảm đau trong quản}

lý đau ung thư. Bệnh nhân trong nghiên cứu được kê đớn đa dạng các thuốc giảm đau trong các nhóm thuốc được khuyến cáo bởi Bộ Y tế và Tổ chức Y tế Thế giới. Nguyên tắc phối hợp các thuốc giảm đau đa mô thức cũng được thể hiện trong các phác đồ bao gồm: phối hợp các nonopioid, non-opioid với opioid, kết hợp với các thuốc hỗ trợ giảm đau. Việc phối hợp thuốc giúp tăng hiệu quả và giảm tác dụng bất lợi từng nhóm thuốc.

Về mối liên hệ giữa phác đồ giảm đau và mức độ đau, phần lớn bệnh nhân đang được duy trì với phác đồ giảm đau bậc 2 , trong đó các thuốc giảm đau non-opioid và opioid yếu thường được phối hợp trong 1 biệt dược. Theo hướng dần của Bộ Y Tế - 2006, việc sứ dụng thuốc giảm đau nển tuân theo thang giảm đau 3 bậc với đau mức độ nặng nên sử dụng phác đồ giảm đau bậc 3 (opioid mạnh \pm non-opioid). Tuy vậy, trong nghiên cứu, 15,2\% bệnh nhân đau mức độ nặng đang được duy trì với phác đồ giảm đau bậc 2.Phác đồ này có thể chưa phù hợp với mức độ đau của họ[1]. Theo hướng dẫn của WHO, các bệnh nhân đau từ mức độ trung bình đến nặng nển được điều trị đau với opioid trong đó nên ưu tiên morphin đường uống [6]. Kết quả thử nghiệm lâm sàng so sánh 2 liệu pháp điều trị morphin liều thấp với opioid yếu ở bệnh nhân có mức độ đau trung bình cho thấy nhóm sử dụng morphin cho hiệu quả điều trị tốt hơn, nhanh hơn, điểm tổng thể tình trạng của bệnh nhân cải thiện hơn. Trong khi đó, tần suất tác dụng phụ của hai nhóm là tương đương và nhóm sử dụng opioid yếu đòi hỏi thay đổi phương pháp điều trị thường xuyên hơn vì giảm đau không đầy đủ.Vì vậy,morphin cũng có thể được cân nhắc như một lựa chọn tiêu chuẩn cho bệnh nhân đau mức độ trung bình, đặc biệt là khi lựa chọn giảm đau ban đầu[2]. Ngoài ra, cũng theo khuyến cáo của WHO, các công thức bào chế kết hợp của thuốc giảm đau non-opioid và opioid không được khuyến khích vì làm mất khả năng hiệu chỉnhmỗi loại thuốc và nguy cơ phơi nhiểm với liều cao tiềm năng độc tính của các non-opioid.Do đó, việc sử dụng rộng rãi các biệt dược phối hợp nên được cân nhắc thêm[6].

Liên quan đến khía cạnh tuân thủ dùng thuốc giảm đau, gần 2/3 số bệnh nhân đã không tuân thủ việc sử dụng thuốc so với đơn kê.Khi so sánh với các nghiên cứu tương tự trên thế giới, tỷ lệ tuân thủ dùng thuốc ghi nhận được dao động khá lớn từ 20-95\%[4]. Tỷ lệ lớn bệnh nhân không tuân thủ là lý do quan trọng dẫn đến hầu hết các bệnh nhân còn đau mức độ trung bình thậm chí đau nặng sau điều trị. Gần $1 / 5$ số bệnh nhân không mổ tả được đúng hướng dẫn dùng thuốc. Trên thực tế, cán bộ y tế thường hướng dẫn trực tiếp cho bệnh nhân hoặc người nhà của họ cách thức sử dụng thuốc.Tuy nhiên, môt bểnh nhân có thể có nhiều người chăm sóc dấn đến sự sai lệch thông tin khi truyền tải giữa những người chăm sóc và bệnh nhân.Thậm chí một số bệnh nhân không được người nhà hướng dấn lại cá́ch dùng thuốc. Đặc biệt,mặc dù được hướng dẫn, bệnh nhân vẫntự ý sử dụng theo cách khác dẫn đến dùng sai chế độ liều hoặc bệnh nhân không dùng thuốc mà cổ gắng chịu đau.Ngoài ra, dạng morphin được kê đơn là viền nang morphin $30 \mathrm{mg}$, tuy nhiên liều sử dụng được kê đơn mỗi lần có thể nhỏ hơn và bệnh nhẩn cần pha một viên thuốc chia thành nhiều liều. Một số bệnh nhân cảm thấy bất tiện với cách dùng thuốc này dẫn đến việc họ uống nguyên viên và giãn khoảng cách dùng thuốc.

Những rào cản trong quản lý đau từ bệnh nhân. Những rào cản chính của bệnh nhân được xác định trong nghiên cứu khá tương đồng với các rào cản chính được xác định trong các nghiên cứu tại các nước châu Á bao gồm: niềm tin rằng thuốc giảm đau chỉ nên được dùng khi đau, cố gắng chịu đau, sợ tác dụng phụ của thuốc, sợ dung nap thuốc $[4,7]$. Đau vốn dĩ là một triệu chứng chủ quan và trong các loại đau thồng thường, thuốc giảm đau chỉ nên được sử dụng khi đau. Tuy nhiên điều trị đau ung thư có những điểm khác biệt, một trong các nguyên tắc quan trọng được hướng dẫn bởi WHO là thuốc giảm đau cần được đưa theo lịch trình cố định để đảm bảo liều tiếp theo được sử dụng trước khi liều phía trước hết tác dụng nhằm duy trì tác dụng giảm đau liên tục [6]. Bên cạnh đó, một số bệnh nhân lo sợ tác dụng phụ của thuốc giảm đau nên hạn chế tối đa việc sử dụng hoặc thậm chí bỏ thuốc hoặc thay thế bằng các loại thuốc khác, bệnh nhân tinrằng thuốc giảm đau sẽ giảm dần tác dụng nên cần phải được sử dụng tiết kiệm phòng khi đau nặng hơn. Tất cả các rào cản 
này có thể là lý do khiến bệnh nhân giảm liều, bớt thuốc, bỏ thuốc và chỉ dùng thuốc khi quá đau qua đó giảm hiệu quả giảm đau.

\section{KẾT LUẦN}

Nghiên cứu đã ghi nhận môt lượng nhỏ bệnh nhân chưa được sử dụng thuốc giảm đau tương xứng với mức độ đau. Tỷ lê không tuân thủ sử dụng thuốc cao và những rào cản chính từ phía bệnh nhân trong quản lý đau ung thư. Các kết quả này là cơ sở cho việc xây dựng một số biện pháp, đặc biệt là các vẩn đề cần can thiệp giáo dụcbệnh nhân nhằm tăng cường hiệu quả giảm đau ung thư.

\section{TÀI LIỆU THAM KHẢO}

1. Bô Y Tế (2006), Hướng dẫn chăm sóc giảm nhe đổi với người bệnh ung thư và AIDS, Nhà xuất bản Y học, Hà Nội, pp.

2. Bandieri E., Romero M., Ripamonti C. I., Artioli F., Sichetti D., Fanizza C., Santini D., Cavanna L., Melotti B., Conte P. F., Roila F., Cascinu S., Bruera E., Tognoni G., Luppi M.
(2016), "Randomized Trial of Low-Dose Morphine Versus Weak Opioids in Moderate Cancer Pain", J Clin Oncol, 34(5), pp. 436-42.

3. National Comprehensive Cancer Network (2020), Adult cancer pain, pp.

4. Oldenmenger $W H$, Sillevis Smitt $P A$, van Dooren S, Stoter G, CC van der Rijt (2009), "A systematic review on barriers hindering adequate cancer pain management and interventions to reduce them: a critical appraisal", Eur J Cancer, 45(8), pp. 1370-1380.

5. Van den Beuken-van Everdingen $\mathbf{M H}_{\text {, }}$ Hochstenbach LM, Joosten EA, Tjan-Heijnen VC, DJ Janssen (2016), "Update on Prevalence of Pain in Patients With Cancer: Systematic Review and Meta-Analysis", J Pain Symptom Manage, 51(6), pp. 1070-1090.

6. World Health Organization (2018), WHO guidelines for the pharmacological and radiotherapeutic management of cancer pain in adults and adolescents, $\mathrm{pp}$.

7. Xu X., Luckett T., Wang A. Y., Lovell M., Phillips J. L. (2018), "Cancer pain management needs and perspectives of patients from Chinese backgrounds: a systematic review of the Chinese and English literature", Palliat Support Care, 16(6), pp. 785-799.

\section{ĐÁNH GIÁ TRÌNH TRANG NẢY CHỒI U TRONG UNG THƯ VÚ THỂ ỐNG XÂM NHẬP BẰNG GIẢI PHẪU BỆNH KỸ THUÂTT Số}

\section{TÓM TẮT}

Trong ung thư biểu mô (UTBM) tuyến vú xâm nhập, NCU độ cao tương quan với kích thước u lớn, xâm nhập mạch, di căn hạch và giảm tỷ lệ sống 5 năm của bệnh nhẩn ung thư vú. Mục tiêu: (1) Xác định tỷ lệ các mức độ nảy chồi u trong ung thư biểu mô tuyến vú thể ống xâm nhâp. (2) Nhân xét môt số mối liên quân giữa các mức nảy chồi u với các đặc điểm giải phẫu bênh. Đối tượng và phương pháp nghiên cứu: Mẫu mô u của 232 bệnh nhân ung thư vú thể ống xâm nhâp được được số hóa tiêu bản thông thường để xác định NCU theo ITBCC 2016 bằng phần mềm kính hiển vi ảo trên máy tính và đánh giá mối liên quan với một số đặc điểm GPB. Kết quả nghiên cứu: Tỷ lệ NCU đô cao trong nhóm ĐMH III là 35,1\%, cao hơn so với tỷ lệ NCU độ cao trong nhóm ĐMH I-II là 20,3\%. Tương tự, ở NC்U đô cao, UTV có di căn hạch là $41,8 \%$, cao hơn 2 lần so nhóm không có di cắn $(20,3 \%)$. Tỷ lệ NCU đô cao trong nhóm u có kích thước pT3 là 63,6\%, cao hơn tỷ lệ NCU độ cao trong nhóm u có kích thước pT1 \& pT2 là 25,8\%. Trong

\section{*Bệnh viện $K$}

Chịu trách nhiẹm chính: Nguyễn Văn Chủ

Email: chunv.nch@gmail.com

Ngày nhận bài:3.8.2021

Ngày phản biện khoa học: 1.10 .2021

Ngày duyệt bài: 12.10.2021

\author{
Nguyễn Văn Chủ*, Lê Thị Uyên**
}

nhóm có xâm nhập mạch bạch huyết, NCU độ cao là $35,6 \%$, cao hơn 1,5 lần so với nhóm không xâm nhâp mạch bạch huyết là 22,5\% ( $p<0,05)$. Kết luận: Có sự tương quan chặt chẽ giữa NCU độ cao với u kích thước lớn, di căn hạch nách, ĐMH cao, xâm nhập mạch bạch huyết.

Tư khóa: Nảy chồi u, Mô bệnh học, Ung thư vú, Giải phẫu bệnh số.

\section{SUMMARY \\ ASSESSMENT OF TUMOR BUDDING IN INVASIVE DUCTAL BREAST CARCINOMA BY DIGITAL PATHOLOGY}

In invasive breast carcinoma, tumor budding, highgrade correlates with tumor size, lymphavascular invasion, lymph node metastasis, and reduced 5-year survival of breast cancer patients. Purpose: (1) Determination of the tumor budding rates in invasive ductal breast carcinoma. (2) Commenting on some relationships between tumor budding levels and pathological characteristics. Methods: Tumor samples of 232 patients with invasive ductal breast cancer were digitized the conventional slides to identify Bds according to ITBCC 2016 by computer virtual microscope software and evaluated the relationship with some pathological features. Results: The rate of high-grade $\mathrm{Bd}$ of the grade III was $35.1 \%$, higher than high-grade Bd of the grade I and II of $20.3 \%$. Similarly, in high-grade Bd, breast cancer with lymph node metastasis was $41.8 \%$, twices higher than the group without metastasis (20.3\%). The rate of high- 
grade Bd in the pT3 tumors was $63.6 \%$, higher than the pT1 \& pT2 (25.8\%). In the tumors with lymphavascular invasion, high-grade Bd was $35.6 \%$, which was 1.5 times higher than that in the group without lymphatic infiltration of $22.5 \% \quad(p<0.05)$. Conclusion: There is a strong correlation between high-grade $\mathrm{Bd}$ and large tumor, axillary lymph node metastasis, high grade, and lymphavascular invasion.

Key words: Tumor budding, Histopathology, Breast cancer, Digital pathology.

\section{I. ĐẶT VẤN ĐỀ}

Các yếu tố tiên lượng trong ung thư vú đóng vai trò đặc biệt quan trọng giúp cung cấp các thông tin cho điều trị và tiên lượng bệnh. Các yếu tố tiên lượng kinh điển như kích thước $u$, typ mô bệnh học (MBH), độ mô học (ĐMH), chỉ số tiên lượng Nottingham (NPI), giai đoạn u, tình trạng hạch và xâm nhập mạch. Gần đây, một số yểu tố mới như nảy chồi u (NCU) được đề cập. NCU là sự xuất hiện các tế bào u độc lập hoặc nhóm nhỏ ít hơn hoă̆c bằng 4 tế bào u. Sư NCU nằm rải rác trong mô đệm ở bờ xâm nhập của khối $u$, có xu hướng mất kết dính và tách ra thành các tế bào đơn lẻ [1].

Thuật ngữ nảy chồi u đã được nghiên cứu trên nhiều loại ung thư đặc không chỉ ung thư vú, như: ung thư đại trực tràng, ung thư dạ dày, ung thư tụy, ung thư vùng đầu cổ, ung thư phối [1]. Trong ung thư biểu mô (UTBM) tuyến vú xâm nhập, NCU độ cao tương quan với kích thước u lớn, xâm nhập mạch máu - bạch huyết và di căn hạch [2]. NCU độ cao với giảm tỳ lệ sống 5 năm của bệnh nhân ung thư vú [3]. Việc số hóa các tiêu bản thông thường đã và đang là một xu hướng rất hiện đại trên thế giới, đem lại nhiều lợi ích to lớn trong thực hành. Ở Việt Nam, NCU đã được nghiên cứu ở một số khối u đặc như ung thư đại trực tràng, da dày, thực quản..., tuy nhiên chưa có công trình nào nghiên cứu trong ung thư vú thể ống xâm nhập (OXN). Vì vậy, chúng tôi chọn đề tài này với mục tiêu:

- Xác định tỷ lệ các mức độ nảy chồi u trong ung thư biểu mô tuyến vú thể ống xâm nhập.

- Nhận xét mốt số mối liên quan giữa các mức nảy chồi u với các đặc điểm giải phấu bệnh.

\section{II. ĐỐI TƯỢNG VÀ PHƯƠNG PHÁP NGHIÊN CỨU}

Đối tượng nghiên cứu: gồm 232 bệnh nhân ung thư biểu mô tuyến vú thể OXN được phẫu thuật điều trị tại bệnh viện K.

Tiêu chuẩn lựa chọn đối tượng

- Có ghi nhận đầy đủ các dữ kiện: họ tên, tuổi, ngày vào viện, vị trí khối u, chẩn đoán lâm sàng và giai đoạn lâm sàng.

- Được phẫu thuật cắt tuyến vú.
- Chẩn đoán xác định bằng mô bệnh học là UTBM thể OXN.

- Có tiêu bản nhuộm H\&E, nhuộm ER, PR, Her2/neu và Ki67.

- Khối u vú nguyên phát và chưa được điều trị hóa chất trước mổ cắt u.

- Ung thư vú ở giai đoạn I-III.

Tiêu chuẩn loại trừ: Các trường hợp sau sẽ bị loại khỏi nghiên cứu:

- Không đáp ứng được các tiêu chuẩn lựa chọn trên.

- Ung thư biểu mô tuyến vú tại chỗ.

- Ung thư vú tái phát hoặc cơ quan khác di căn tới vú.

- Ung thư vú ở nam giới.

\section{Phương pháp nghiên cứu}

- Thiết kế nghiên cứu: là nghiên cứu mô tả cắt ngang.

- Mẫu nghiên cứu: Mẫu không xác suất, loại mẫu có chủ đích.

- Nội dung nghiên cứu/ Các biến số và chỉ số trong nghiên cứu:

+ Đặc điểm chung

- Kích thước u: $\leq 2 \mathrm{~cm},>2-5 \mathrm{~cm}$ và $>5 \mathrm{~cm}$

- Vị trí u: Vú phải, vú trái, hai bên

- Giai đoạn bệnh: theo AJCC 8

- Hoại tử u: có/không

- Tỉ lệ các typ mô bệnh học: theo phân loại WHO 2019

- Tình trạng bộc lộ ER, PR, Heu-2, Ki67: dương tính/âmm tính

- Tình trạng di căn hạch nách: 0, 1-3, >3 hạch

- Xâm nhập mạch: có/không

+ Mục tiêu 1

- Độ NCU: chia làm 3 độ I, II và III theo ITBCC 2016

\begin{tabular}{|c|c|}
\hline Độ nảy chồi u & Đặc điếm \\
\hline III & $\geq 10$ chồi \\
\hline II & $5-9$ chồi \\
\hline I & $0-4 \quad$ chồi \\
\hline
\end{tabular}

- Độ I, II và III được nhóm thành độ thấp (I và II) và độ cao (III).

+ Mục tiêu 2: Đối chiếu độ NCU (thấp-vừa \& cao) với kích thước u và các đặc điểm $\mathrm{MBH}$ : typ $\mathrm{MBH}, \mathrm{DMH}$ (I và II, III), giai đoạn $u$, hoại tử u, di căn hạch (có/không), xâm nhập mạch (có/không), ER (dương tính/âm tính), PR (dương tính/âm tính), Ki67 (dương tính thấp và cao), Her2/neu (dương tính/âm tính).

- Quy trình nghiên cứu

+ Đặc điểm chung: lập danh sách bệnh nhân và thu thập thông tin từ bệnh án.

+ Đặc điểm mô bệnh học và đặc điểm nảy chồi u 
- Đặc điểm $\mathrm{MBH}$ : thu thập các tiêu bản nhuộm $\mathrm{HE}$, đọc và phân tích kết quả trên kính hiển vi quang học. Trường hợp tiêu bản không đảm bảo chất lượng sẽ làm tiểu bản mới từ khối nến còn lại của bệnh nhân.

- Số hóa tiêu bản HE và đánh giá đặc điểm nảy chồi u: Các tiêu bản HE được quét bằng máy Scan tiêu bản Leica Aperio AT2 với các độ phóng đại khác nhau để số hóa. Các tiêu bản số này được đọc bằng phần mềm trên máy tính ở vật kính ảo phóng đại 200 lần và phân độ nảy chồi u theo quy trình của ITBCC 2016.

- Bộ công cụ nghiên cứu và kĩ thuật thu thập số liệu: Hệ thống máy Scan tiêu bản Leica Aperio AT2 và phiếu nghiên cứu.

Phân tích và xử lý số liệu: Xử lý số liệu bằng phần mềm SPSS 16. Áp dụng test $X 2$ để so sánh hai hoặc nhiều tỷ lệ, tính giá trị p. Các phép so sánh có $\mathrm{p}<0,05$ được coi là có ý nghĩa thống kê.

\section{KẾT QUẢ NGHIÊN CỨU}

Bảng 1. Tình trạng nảy chồi u

\begin{tabular}{|c|c|c|c|c|c|}
\hline \multicolumn{2}{|c|}{ Độ NCU } & \multicolumn{2}{|c|}{$\mathbf{N}$} & \multicolumn{2}{|c|}{$\%$} \\
\hline $\begin{array}{c}\text { I } \\
\text { II }\end{array}$ & Thấp & $\begin{array}{c}103 \\
65\end{array}$ & 168 & $\begin{array}{l}44,4 \\
28,0\end{array}$ & 72,4 \\
\hline III & Cao & \multirow{2}{*}{\multicolumn{2}{|c|}{$\begin{array}{c}64 \\
232\end{array}$}} & \multirow{2}{*}{\multicolumn{2}{|c|}{$\begin{array}{c}27,6 \\
\mathbf{1 0 0 , 0}\end{array}$}} \\
\hline & & & & & \\
\hline
\end{tabular}

Nhân xét: Tỷ lệ NCU độ thấp là 72,4\%, trong đó độ I là 44,4\% với 103 trường hợp, chiếm tỉ lệ cao nhất trong mẫu nghiên cứu và NCU độ II với 65 trưởng hợp, chiếm 28,0\%. Tỷ lệ NCU độ III (độ cao) là $27,6 \%$ với 64 trường hơp.

Bảng 2. Đối chiếu đặc điểm NCU với một số đặc điểm giải phẫu bệnh

\begin{tabular}{|c|c|c|c|c|c|c|}
\hline \multirow{2}{*}{\multicolumn{2}{|c|}{ Độ NCU }} & \multirow{2}{*}{\multicolumn{2}{|c|}{ Độ thấp }} & & & \\
\hline & & & & \multicolumn{2}{|c|}{ Đố cao } & $\mathbf{p}$ \\
\hline \multirow[b]{2}{*}{ ĐMH } & I-II & 94 & 79,7 & 40 & 35,1 & \multirow{2}{*}{0,012} \\
\hline & III & 74 & 64,9 & 24 & 20,3 & \\
\hline \multirow{2}{*}{$\begin{array}{l}\text { Di căn } \\
\text { hạch }\end{array}$} & 0 & 122 & 79,7 & 31 & 20,3 & \multirow{2}{*}{0,001} \\
\hline & $1-3$ & 46 & 58,2 & 33 & 41,8 & \\
\hline \multirow{2}{*}{ pT } & T1-2 & 164 & 74,2 & 57 & 25,8 & \multirow{2}{*}{0,006} \\
\hline & T3 & 4 & 36,4 & 7 & 63,6 & \\
\hline \multirow{2}{*}{ XN mạch } & Không & 110 & 77,5 & 32 & 22,5 & \multirow{2}{*}{0,031} \\
\hline & Có & 58 & 64,4 & 32 & 35,6 & \\
\hline \multirow{2}{*}{ Hoại tử } & Không & 136 & 72,7 & 51 & 27,3 & \multirow{2}{*}{0,828} \\
\hline & Có & 32 & 71,1 & 13 & 28,9 & \\
\hline
\end{tabular}

Nhận xét: Tỷ lệ NCU độ cao trong nhóm ĐMH III là $35,1 \%$, cao hơn so với tỷ lệ NCU độ cao trong nhóm ĐMH I-II là 20,3\%. Tương tự, ở NCU độ cao, UTV có di căn hạch là 41,8\%, cao hớn 2 lần so nhóm không có di căn (20,3\%). Tý lệ NCU độ cao trong nhóm u có kích thước pT3 là $63,6 \%$, cao hơn tỷ lệ NCU độ cao trong nhóm u có kích thước pT1 \& pT2 là 25,8\%. Trong nhóm có xâm nhập mạch bach huyết NCUU độ cao là 35,6\%, cao hơn 1,5 lần so với nhóm không xâm nhập mạch bạch huyết là $22,5 \%$. Tỷ lệ NCU độ cao ở nhóm có hoại tử u và không hoại tử của tỷ lệ gần tương tự nhau (lần lượt là 28,9 và $27,3 \%$ ).

Bảng 3. Nảy chối u và sự bộc lộ các dấu ấn HMMD

\begin{tabular}{|c|c|c|c|c|c|c|}
\hline \multirow{2}{*}{\multicolumn{2}{|c|}{ Độ NCU }} & \multicolumn{2}{|c|}{ Đô thấp } & \multicolumn{2}{|c|}{ Đố cao } & \multirow{2}{*}{$\mathbf{p}$} \\
\hline & & $\mathbf{N}$ & $\%$ & $\mathbf{n}$ & $\%$ & \\
\hline \multirow[b]{2}{*}{ ER } & $(-)$ & 69 & 67,0 & 34 & 33,0 & \multirow{2}{*}{0,099} \\
\hline & $(+)$ & 99 & 76,7 & 30 & 23,3 & \\
\hline \multirow{2}{*}{ PR } & $(-)$ & 75 & 67,0 & 93 & 77,5 & \multirow{2}{*}{0,073} \\
\hline & $(+)$ & 37 & 33,0 & 27 & 22,5 & \\
\hline \multirow{2}{*}{ HER2 } & $(-)$ & 93 & 76,2 & 29 & 23,8 & \multirow{2}{*}{0,171} \\
\hline & $(+)$ & 75 & 68,2 & 35 & 31,8 & \\
\hline \multirow{2}{*}{ Ki67 } & Thấp & 87 & 75,0 & 29 & 25,0 & \multirow{2}{*}{0,378} \\
\hline & Cao & 81 & 69,8 & 35 & 30,2 & \\
\hline
\end{tabular}

Nhận xét: Tỷ lệ NCU độ cao ở nhóm ER(-) là $33,0 \%$ cao hơn nhóm $\mathrm{ER}(+)$ là $23,3 \%$. Tương tự, trong UTV PR(-), NCU đô cao là $33,0 \%$, cao hơn nhóm có $\mathrm{PR}(+)$ là $22,5 \%$. Trái lại, NCU độ cao trong nhóm bộc lộ HER2(+) là 31,8\%, cao hơn với tỷ lệ NCU độ cao UTV HER2(-) là 23,8\%. Tỷ lê NCU độ cao trong nhóm có chỉ số Ki67 cao là $30,2 \%$, cao hơn với tỷ lệ NCU độ cao trong 
nhóm có chỉ số Ki67 thấp là 25,0\%.

\section{BÀN LUẬN}

Giải phẫu bênh kỹ thuật số phát triển mạnh trong một vài năm gần đây. Việc số hóa tiêu bản thông thường đã đem lại nhiều lợi ích to lớn cho việc chẩn đoán, đào tạo, nghiên cứu khoa học và hội chẩn. Chúng tôi đánh giá NCU trên tiêu bản nhuộm HE đã được số hóa, sử dụng phương pháp đếm NCU ở vùng "hotspot" của ITBCC 2016 [1]. Số lượng NCU thấp nhất là 0 chồi u/0,785 mm²; cao nhất là 33 chồi u/ $0,785 \mathrm{~mm}^{2}$; trung bình là 7 chồi $u / 0,785 \mathrm{~mm}^{2}$. NCU độ cao chiếm tỷ lệ 27,6\% với 103 trường hợp. NCU độ trung bình và độ thấp chiếm lần lượt $28 \%$ và $44,4 \%$. NCU sẽ được đếm với độ chính xác tốt hơn nếu được đếm trên 10 vi trường. Các nghiên cứu sử dụng các điểm cắt khác nhau để phân độ các mức NCU. Nghiên cứu của chúng tôi chia làm ba độ: độ thấp (0-4 NCU), độ trung bình (5-9 $\mathrm{NCU})$ và độ cao ( $\geq 10 \mathrm{NCU}$ ) tương tự cách phân độ trong nghiên cứu của Sun và cS [4] cho kết quả NCU hai nghiên cứu tương tự nhau. Tuy nhiên cũng có sự khác biệt về tỷ lệ NCU khá nhiều giữa các nghiên cứu có thể do sử dụng các phương pháp đếm khác nhau. Trong đó tỷ lệ NCU độ cao chiếm tỷ lệ cao nhất trong hai nghiên cứu của Salhia và $\mathrm{Cs}$, Masilamani và $\mathrm{CS}$ lần lượt là $88,5 \%$ và $80,4 \%[5,6]$.

Trong nghiên cứu của chúng tôi, tỷ lệ NCU độ cao trong nhóm Độ III là 35,1\% (40/114 trường hợp), cao hơn so với tỷ lệ NCU độ cao trong nhóm ĐMH I-II là 20,3\% (24/118 trường hợp). Sự khác biệt này có ý nghĩa thống kê với $\mathrm{p}=$ $0,012(<0,005)$. Kết quả của chúng tôi tương đồng với tác giả Sriwidyani và cs $(p=0,03)$ [7]. Nghiên cứu của Renuka và cs cho kết quả NCU không có tương quan với ĐMH nhưng có mối liên quan với độ mô học với $p=0,048$ [8].

Nghiên cứu của chúng tôi nhận thấy có sự khác biệt giữa phân độ NCU và số lượng hạch di căn hạch: u di căn nhiêu hạch có tỷ lệ NCU độ cao cao hơn so với nhóm di căn ít hạch và sự khác biệt này có ý nghĩa thống kê với $\mathrm{p}<0,001$. Kết quả của chúng tôi tương tự với một số nghiên cứu nước ngoài, nghiên cứu của Gujam và cs [3] cho kết quả tỷ lệ NCU độ cao trong nhóm có di căn hạch là $41,5 \%$ cao hơn so với tỳ lệ NCU độ cao trong nhóm không di căn hạch (30\%), mối liên quan có ý nghĩa thống kê với $p$ $=0,009$. Nghiên cứu của Masilamani và cs [6] trên 107 bệnh nhân thây rằng trong số 43 trường hợp di căn hạch thì có tới 90,7\% NCU độ cao; trong khi chỉ 73,4\% NCU độ cao xảy ra trên những bệnh nhân không di căn hạch. Kết quả nghiên cứu cho thấy có mối liên quan đáng kể giữa NCU độ cao và tình trạng di căn hạch với $p$ $<0,05$. Kết quả nghiên cứu của chúng tôi ủng hộ các nghiên cứu trước đây cho rằng NCU là yểu tố mô bệnh học có khả năng tiên lượng tình trạng di căn hạch trong ung thư vú mặc dù sử dụng các phương pháp đánh giá khác nhau.

Trong nghiên cứu của chúng tôi cho thấy $\mathrm{NCU}$ có mối tương quan với kích thước u ( $p=$ 0,006 ). Kết quả của chúng tôi tương tự nghiên cứu của Liang và cs [2]. Tương tự, nghiên cứu của các tác giả Sriwidyani và cs [7], Agarwal và Cs [9], Kumarguru và cs [10] cũng cho thây NCU có mối liên quan với kích thước u trong UTBM xâm nhập.

Chúng tôi nhận thấy tỷ lệ NCU độ cao trong nhóm có xâm nhập mạch bạch huyết là $35,6 \%$, cao hơn 1,5 lần so với tỷ lệ NCU độ cao trong nhóm không xâm nhập mạch bạch huyết là $22,5 \%$. Sự khác biệt này có ý nghĩa thống kê với $p=0,031$. Ngược lại trong một nghiên cứu cho kết quả không có sự tương quan có ý nghĩa giữa các mức độ NCU với tình trạng xâm nhập mạch bạch huyết $(p=0,553)$. Mặc dù không có ý nghĩa thống kê nhưng tỷ lệ NCU dương tính trong nhóm xâm nhập mạch $80 \%$ cao hơn trong nhóm không có xâm nhập mạch $(73,1 \%)$. Một phân tích gộp của cũng đã cho thấy có mối tương quan giữa NCU với tình trạng xâm nhập mạch bạch huyết. Tỷ lệ NCU trong nhóm có xâm nhập mạch bạch huyết cao hơn trong nhóm khồng có xâm nhập mạch. Điều này phù hợp với quá trình EMT trong sự tiến triển và di căn của ung thư. Các tế bào chồi u là các tế bào đang trải qua EMT, diễn ra các thay đổi sinh học cho phép xâm nhập mạch bạch huyết và là mầm mống của di cắn xa.

Nghiên cứu của chúng tôi cho thấy không có mối liên quan giữa NCU và tình trạng hoại tử u với $p=0,828$. Kết quả này tương tự nghiển cứu của Gujam và $c s(p=0,107)[3]$, Agarwal và $c s$ $(p=0,283)[9]$. Theo của Kumarguru và cs, tỷ lệ NCU độ cao có mối liên quan với các trường hợp có hoại tử u.

Khi đánh giá sự bộc lộ ER, kết quả nghiên cứu của chúng tôi tượng tự các nghiên cứu của Liang và cs [2], Sriwidyani và cs [7], Masilamani và cs [6], Agarwal và cs [9], Renuka và cs [6]. Tuy nhiên, nghiên cứu của Gujam và cs [3], Salhia và cs [5] cho thấy mối tương quan giữa NCU với sự bộc lộ ER. Tỷ lệ NCU độ cao trong nhóm bộc lộ ER dương tính cao hơn tỷ lệ NCU độ 
cao trong nhóm ER âm tính. Theo kết quả nghiên cứu Gujam và cS, cho thấy NCU độ cao có liên quan đáng kể với các khối u ER dương tính. Gần đây, đã có báo cáo rằng estrogen có liên quan đến quá trình EMT [3], liên quan đến sự phá vỡ mối nối giữa các tế bào biểu mô và tăng khả năng vận động của các tế bào. Do đó, các khối u $E R(+)$ thì có thể trải qua mức độ EMT cao hơn và tiêm năng di căn nhiều hơn. Theo Sun và cs (2014) [6], estrogen có liên quan đến EMT trong các dòng tế bào UTV có đặc tính tế bào gốc (CSC), CSC đóng vai trò quan trọng trong sự phát triển, xâm lấn, di căn khối u, chống lại các tác nhân gây độc tế bào. Kết quả nghiên cứu của Sun và cs chỉ ra rằng hoạt động thông qua Gli1 (kích hoạt phiên mã Gli1) để thúc đẩy sự phát triển của CSC và ETM trong các tế bào UTV có ER dương tính.

Đối với sự bộc lộ $P R$, các nghiên cứu của Liang và cs [2], Gujam và cs [3], Sriwidyani và cs [7], Masilamani và cs [6], Agarwal và cs [9] đều cho kết quả không có mối tương quan giữa NCU và sự bộc lộ PR. Một số tác giả khi so sánh sự bộc lộ HMMD giữa các tế bào chồi u và khối u chính chỉ quan sát thấy sự khác biệt về tình trang bộc PR. Các thí nghiệm trên các dòng tế bào ung thư vú đã chứng minh rằng gắn với $P R$ có thể dẫn đến ức chế các protein liên quan đến EMT và $P R$ âm tính là yếu tố độc lập làm giảm tỷ lệ sống sót.

Trong sự bộc lộ HER2, nghiên cứu của Liang và cs [2], Gujam và cs [3], Salhia và cs [5], Sriwidyani và cs [7], Agarwal và cs [9] cho kết quả không có mối tương quan giữa NCU và sự bộc lộ HER2. Ngược lại, nghiên cứu của Masilamani và cs [6] chỉ ra rằng NCU độ cao có liên quan đến các khối u có HER2 dương tính.

Đánh giá sư bộc lộ Ki67, các nghiên cứu của Gujam và cs [3], Masilamani và cs [6] cho kết quả giống với nghiên cứu của chúng tôi. Nghiên cứu của Salhia và cs [5], Sriwidyani và cs [7] chỉ ra mối tương quan giữa NCU và sự bộc lộ Ki67, trong nghiên cứu Salhia và cs [5] chỉ ra rằng tý lệ NCU độ cao liên quan đến u có chỉ số Ki67 thấp ( $\leq 15 \%)$. Mức độ bộc lộ Ki67 càng cao thì tiên lượng càng xấu, tuy nhiên các nghiên cứu về quá trình EMT cho thấy các tế bào của chồi u cũng biểu hiện mức độ thấp của chỉ số Ki67 và không có dấu hiệu tăng sinh. Nghiên cứu của một số tác giả trền ung thư đại trực tràng cũng cho kết quả tương tự Ki67 không bộc lộ trong hầu hết các tế bào của chồi u.

\section{KẾT LUÂN}

Qua nghiên cứu đánh giá NCU của 232 bệnh nhân ung thư biểu mô tuyến vú thể ống xâm nhập chúng tôi rút ra một số nhận xét sau:

- NCU độ thấp là $72,4 \%$, trong đó độ I chiếm tỉ lệ cao nhất là $44,4 \%$ và độ II là $28,0 \%$. Tỷ lệ NCU độ cao (độ III) chiếm 27,6\%.

- Có sự tương quan chặt chẽ giữa NCU độ cao với u kích thước lớn, di căn hạch nách, ĐMH cao, xâm nhập mạch bạch huyết $(p<0,05)$. Tuy nhiên, chưa thây sự tương quan giữa mức độ NCU với tình trạng hoại tử u và đặc điểm HMMD.

\section{TÀI LIỆ THAM KHẢO}

1. Lugli A, Kirsch $R$, Ajioka $Y$, et al. Recommendations for reporting tumor budding in colorectal cancer based on the International Tumor Budding Consensus Conference (ITBCC) 2016. Modern pathology : an official journal of the United States and Canadian Academy of Pathology, Inc. Sep 2017;30(9):1299-1311.

2. Liang F, Cao W, Wang Y, Li L, Zhang G, Wang $\mathbf{Z}$. The prognostic value of tumor budding in invasive breast cancer. Pathology, research and practice. May 2013;209(5):269-75.

3. Gujam FJ, McMillan DC, Mohammed ZM, Edwards J, Going JJ. The relationship between tumour budding, the tumour microenvironment and survival in patients with invasive ductal breast cancer. British journal of cancer. Sep 29 2015;113(7):1066-74. doi:10.1038/bjc.2015.287

4. Sun $\mathbf{Y}$, Liang $\mathbf{F}$, Cao $\mathbf{W}$, et al. Prognostic value of poorly differentiated clusters in invasive breast cancer. World journal of surgical oncology. Oct 12 2014;12:310.

5. Salhia B, Trippel M, Pfaltz $K$, et al. High tumor budding stratifies breast cancer with metastatic properties. Breast cancer research and treatment. Apr 2015;150(2):363-71.

6. Masilamani DS, P DK. Evaluation of clinicopathologic significance of tumor budding in breast carcinoma. International Journal of Clinical and Diagnostic Pathology. 2019;2(1):171-173.

7. Sriwidyani NP, Manuaba IBTW, Alit-Artha IG, Mantik-Astawa IN. Tumor Budding in Breast Carcinoma: Relation to E-Cadherin, MMP-9 Expression, and Metastasis Risk. Tumor budding, E-cadherin, MMP-9, metastasis, breast carcinoma. 2016. 2016-10-22 2016;5(3):5.

8. Renuka IV, Madhavi $K$, Premalatha $P$, Krishnamacharyulu P, Vaishnavi R. Tumor budding in invasive carcinoma of breast of No Special Type (NST): Value as a prognostic factor. IP J Diagn Pathol Oncol 2019;4(2):15-129.

9. Agarwal $\mathbf{R}$, Khurana $\mathbf{N}$, Singh $T$, Agarwal PN. Tumor budding in infiltrating breast carcinoma: Correlation with known clinicopathological parameters and hormone receptor status. Indian journal of pathology \& microbiology. Apr-Jun 2019;62(2):222-225. 


\section{KHẢO SÁT THỰC TRẠNG GIÁO DỤC SỨC KHỎE CHO NGƯờI BÊNH TĂNG HUYẾT ÁP TẠI BỆNH VIỆN TRƯỜNG ĐẠI HỌC Y KHOA VINH NĂM 2020}

\section{TÓM TẮT}

Mục tiêu: 1. Mô tả thực trạng giáo dục sức khỏe cho NB tăng huyết áp tại bệnh viện Trường đại học Y khoa Vinh năm 2020. 2. Khảo sát hiệu quả giáo dục sức khỏe cho NB tăng huyết áp hiện nay tai bệnh viện Trường đại học Y khoa Vinh năm 2020. Đối tượng và phương pháp nghiên cứu: Nghiên cứu mô tá cắt ngang 50 NB được chẩn đoán THA đến khám và điều trị tại Bệnh viện Trường Đại học Y khoa Vinh từ tháng 08/2020 đến tháng 10/2020. Kết quả: 100\% người bệnh tăng huyết áp được nhân viên y tế giáo dục sức khỏe. Đa số người bệnh có kiến thức về bệnh THA như biểu hiện, trị số huyết áp, thời điểm đo huyết áp bênh THA. 72\% người bênh có kiến thức về nguyên tắc điều trị THA là điều trị lâu dài; chỉ có $4 \%$ người bệnh không biết nguyên tắc điều trị của bênh THA. Kết luận: Giáo dục sức khoẻ cho người bệnh THA tại bệnh viện Trường đại học Y khoa Vinh năm 2020 được thực hiện có hiệu quả tuy nhiên bệnh viện cần có chương trình GDSK cho người bênh THA tiến hành đánh giá thường xuyên hiệu quả hoạt động truyền thông, giáo dục sức khỏe cho người bệnh.

Tư khóa: tăng huyết áp, NB, giáo dục sức khỏe.

\section{SUMMARY}

\section{SURVEY ON THE SITUATION OF HEALTH EDUCATION FOR HYPERTENSIVE PATIENT AT THE HOSPITAL OF VINH MEDICAL UNIVERSITY IN 2020}

Objectives: 1 . Describe the current situation of health education for hypertensive patients at Vinh Medical University Hospital in 2020. 2. Survey the effectiveness of health education for hypertensive patients at Vinh University Medicine Hospital in 2020. Subjects and methods: A cross-sectional descriptive study of 50 patients diagnosed with hypertension who came for examination and treatment at Vinh Medical University Hospital from August 2020 until October 2020. Results: 100\% of hypertensive patients received health education by medical staffs. Most patients have knowledge about hypertension such as symptoms, blood pressure values, and time to measure blood pressure. $72 \%$ of patients have knowledge about the principles of hypertension treatment as long-term treatment; Only $4 \%$ of patients do not know the principles of treatment of hypertension. Conclusion: Health education for hypertensive patients at Vinh Medicine University Hospital in 2020 is effective, but the

${ }^{1}$ Trường Đại hoc Y khoa Vinh

Chịu trách nhiệm chính: Đinh Thị Hằng Nga

Email: ngadinh.dhykvinh@gmail.com

Ngày nhận bài: 9.8.2021

Ngày phản biên khoa học: 4.10 .2021

Ngày duyệt bài: 15.10 .2021

\section{Đinh Thị Hằng Nga ${ }^{1}$, Hồ Thị Hải Lế}

hospital needs a health education program for hypertensive patients to regularly evaluate the effectiveness of communication and health education activities for patients.

Keywords: hypertension, patients, health education.

\section{I. ĐĂT VẤN ĐỀ}

THA là bệnh lý xuất hiện âm thầm nhưng để lại biến chứng nghiêm trọng cho NB khi không được kiểm soát tốt. Trong những năm gần đây, tỷ lệ tử vong do các biến chứng của bệnh THA ngày một tăng ở các nước đang phát triển, trong đó có Việt Nam. Theo Hội tim mạch Việt Nam 2015 cho thấy tại Việt Nam có đến $47.3 \%$ người trên 25 tuổi bị mắc HA [1]. Bệnh để lại di chứng rất nặng và có thể tử vong do những biến chứng của bệnh hoặc do tai biến điều trị. GDSK là một công tác khó làm và khó đánh giá kết quả, nhưng nếu làm tốt sẽ mang lại hiệu quả cao nhất với chi phí ít nhất, nhất là ở tuyến y tế cơ sở. Theo tổ chức y tế thế giới, $80 \%$ bệnh tim mạch, đái tháo đường có thể phòng được thông qua thực hiện lối sống lành mạnh loại bỏ các yếu tố liên quan hành vi [3].

Hiện nay, tại bệnh viện trường đại học Y khoa Vinh lượng người có bệnh THA đến khám và điều trị ngày càng tăng lên. Số lượng NB trung bình trong một tháng cần nằm và điều trị tại bệnh viện có xu hướng gia tăng. Thực trạng triển khai công tác GDSK cho NB THA tại bệnh viện trường đại học $Y$ khoa Vinh đã triển khai như thế nào? Hiệu quả của chương trình GDSK NB THA tại bệnh viện trường đại học y khoa Vinh như thế nào? Mục tiêu nghiên cứu

1. Mô tả thực trang giáo dục sức khỏe cho NB tăng huyêt áp tại bệnh viện Trường đại học Y khoa Vinh năm 2020

2. Khảo sát hiệu quả giáo dục sức khỏe cho NB tăng huyết áp hiện nay tại bệnh viện Trường đại hoc Y khoa Vinh năm 2020

\section{II. ĐỐI TƯỢNG VÀ PHƯƠNG PHÁP NGHIÊN CỨU}

1. Đối tượng nghiên cứu: NB THA đến khám và điều trị tại Bệnh viện Trường Đại học $Y$ khoa Vinh.

2. Thời gian và địa điểm nghiên cứu: Từ tháng 08/2020 đến tháng 10/2020, tại Bệnh viện Trường Đại học $Y$ khoa Vinh

3. Phương pháp nghiên cứu: Nghiên cứu mô tả cắt ngang 
4. Cỡ mẫu: Cõ̃ mẫu là 50 với phương pháp chọn mẫu thuận tiện.

5. Phương pháp phân tích số liêu: Các số liệu điều tra được thu thập và xử lý qua qua Exel

\section{KẾT QUẢ NGHIÊN CỨU}

1. Thực trạng GDSK cho NB THA tại bệnh viện Trường đại học $Y$ khoa Vinh năm 2020

Bảng 3.2. Thức trang GDSK của NB THA tại BV trường ĐH Y khoa Vinh $(n=50)$

\begin{tabular}{|c|c|c|c|}
\hline \multicolumn{2}{|c|}{ Thông tin chung } & \multirow{2}{*}{$\begin{array}{c}\text { Tân suất } \\
\text { (n) }\end{array}$} & \multirow{2}{*}{$\begin{array}{c}\begin{array}{c}\text { Tỷ lệ } \\
\text { \% }\end{array} \\
100,0\end{array}$} \\
\hline $\begin{array}{c}\text { Oược nhâr } \\
\text { viển y tế } \\
\text { GDSK }\end{array}$ & Có & & \\
\hline \multirow{2}{*}{$\begin{array}{c}\text { Người thự } \\
\text { hiện tư } \\
\text { vấn GDSK }\end{array}$} & Điều dương & 37 & 74,0 \\
\hline & Bác sĩ & 44 & 88,0 \\
\hline \multirow{2}{*}{$\begin{array}{c}\text { Hình thức } \\
\text { GDSK }\end{array}$} & $\begin{array}{l}\text { Tố chức nói } \\
\text { chuyện GDSK }\end{array}$ & 16 & 32,0 \\
\hline & Tư vấn cá nhân & 40 & 80,0 \\
\hline \multirow{3}{*}{$\begin{array}{l}\text { Tài liệu } \\
\text { dùng để tı } \\
\text { vấn GDSK }\end{array}$} & Tờ rơi & 10 & 20,0 \\
\hline & Tài liệu phát tay & 36 & 72,0 \\
\hline & Tranh ảnh & 4 & 8,0 \\
\hline \multirow{3}{*}{$\begin{array}{c}\text { Thời điểm } \\
\text { NB THA } \\
\text { được } \\
\text { GDSKK }\end{array}$} & Lúc vào viện & 23 & 46,0 \\
\hline & $\begin{array}{l}\text { Trong quá trình } \\
\text { điêuu trị }\end{array}$ & 29 & 58,0 \\
\hline & Trước lúc ra viện & 26 & 52,0 \\
\hline \multirow{9}{*}{$\begin{array}{c}\text { Nội dung } \\
\text { GDSK }\end{array}$} & Nguyên nhân & 27 & 54,0 \\
\hline & Triệu chứng THA & 34 & 68,0 \\
\hline & Điều trị & 33 & 66,0 \\
\hline & Biến chứng & 32 & 64,0 \\
\hline & $\begin{array}{l}\text { Cách dự phòng } \\
\text { biến chứng }\end{array}$ & 43 & 86,0 \\
\hline & Chế độ dinh dưỡng & 42 & 84,0 \\
\hline & Tuân thủ dùng thuốc & 41 & 82,0 \\
\hline & Tái khám & 46 & 92,0 \\
\hline & Vận động & 33 & 66,0 \\
\hline
\end{tabular}

Tỉ lê NB THA được nhân viên y tế GDSK cao $(100 \%)$; người thực hiện GDSK cho NB là bác sĩ chiếm tỉ lệ cao hơn $(88,0 \%)$; hình thức GDSK qua tư vấn cá nhân chiếm tỉ lệ cao $(80,0 \%)$, hình thức tổ chức nói chuyện GDSK còn thấp $(32,0 \%)$; tài liệu phát tay được sử dụng để tư vấn GDSK chiếm tỉ lệ cao nhất $(72,0)$

NB được GDSK tương đối đồng đều ở cả 3 thời điểm, hướng dẫn NB tái khám $(92,0 \%)$, cách dự phòng biến chứng $(86,0 \%)$. Thấp nhất là nguyên nhân $(54,0 \%)$, hướng dẫn vận động $(66,0 \%)$

2. Đánh giá hiệu quả hương trình GDSK cho NB THA tại bệnh viện Trường đại học $Y$ khoa Vinh hiện nay

Bảng 3.3. Kiến thức của NB về bệnh THA

\begin{tabular}{|c|c|c|c|}
\hline \\
\hline \multicolumn{2}{|c|}{ Thông tin chung } & $\mid \begin{array}{c}\text { Tấn } \\
\text { suất(n) }\end{array}$ & $\begin{array}{l}\text { Tỳ lệ } \\
\% \%\end{array}$ \\
\hline \multirow{6}{*}{$\begin{array}{c}\text { Biểu } \\
\text { hiện bệnh } \\
\text { THA }\end{array}$} & Nhức đâu sau gáy & 23 & 46,0 \\
\hline & Chóng mặt, hoa mắt & 42 & 84,0 \\
\hline & Buồn nôn & 24 & 48,0 \\
\hline & Nóng bừng mặt & 28 & 56,0 \\
\hline & Mệt mỏi & 38 & 76,0 \\
\hline & Không biết & 0 & 0 \\
\hline \multirow{3}{*}{$\begin{array}{l}\text { Chỉ số HA } \\
\text { để đánh } \\
\text { giá trình } \\
\text { trạng THA }\end{array}$} & $\begin{array}{l}\text { HA tối đa } \geq \\
140 \mathrm{mmHg}\end{array}$ & 31 & 62,0 \\
\hline & $\begin{array}{c}\text { HA tối thiểu } \geq \\
90 \mathrm{mmHg}\end{array}$ & 10 & 20,0 \\
\hline & $\begin{array}{l}\mathrm{HATÐ} \geq 140 \mathrm{mmHg} \\
\text { và } \mathrm{HATT} \geq 90 \mathrm{mmHg}\end{array}$ & 27 & 54,0 \\
\hline \multirow{3}{*}{$\begin{array}{c}\text { Kiến thức } \\
\text { về thời } \\
\text { điểm đo } \\
\text { HA }\end{array}$} & Hằng ngày & 46 & 92,0 \\
\hline & Thường xuyên & 12 & 24,0 \\
\hline & $\begin{array}{c}\text { Khi mệt mỏi, đau đầu } \\
\text { chóng mặt }\end{array}$ & 24 & 48,0 \\
\hline \multirow{4}{*}{$\begin{array}{c}\text { Kiến thức } \\
\text { về chế độ } \\
\text { dinh } \\
\text { dưỡng cho } \\
\text { NB THA }\end{array}$} & Đủ năng lượng & 28 & 56,0 \\
\hline & $\begin{array}{c}\text { Tăng cường rau xanh } \\
\text { hoa quả }\end{array}$ & 34 & 68,0 \\
\hline & \begin{tabular}{|c|} 
Hạn chế: chất béo, \\
muô̂i, rượu bia, thuốc \\
lá, chất kích thích
\end{tabular} & 50 & 100 \\
\hline & Đủ nước & 20 & 40,0 \\
\hline
\end{tabular}

NB có kiến thức về biểu hiên bênh THA cao nhất là hoa mắt, chóng mặt $(84,0 \%)$, NB có kiến thức về trị số $\mathrm{HA}$ tăng, cao nhất là $\mathrm{HA}$ tối đa $\geq$ $140 \mathrm{mmHg}(62,0 \%)$, HA tối thiểu $\geq 90 \mathrm{mmHg}$ $(20,0 \%)$, NB có kiến thức về thời điểm đo HA tai nhà cao nhất là hằng ngày $(92,0)$; $\mathrm{NB}$ có kiến thức về chế độ dinh dưỡng cho người THA cao nhất là hạn chế: chất béo, muối, rượu bia, thuốc lá, chất kích thích (100\%)

Bảng 3.4: Kiến thức về yêu tố nguy cơ của bệnh THA $(n=50)$

\begin{tabular}{|c|c|c|}
\hline Yếu tố nguy cơ & $\begin{array}{c}\text { Tân suất } \\
\text { (n) }\end{array}$ & $\begin{array}{c}\text { Tỷ lệ } \\
\text { \% }\end{array}$ \\
\hline$>45$ tuổi & 33 & 66,0 \\
\hline Thừa cân & 36 & 72,0 \\
\hline Sử dụng rượu bia, thuốc lá & 33 & 66,0 \\
\hline Án nhiều muối, ít rau quả. & 31 & 62,0 \\
\hline İt hoạt động thế lực. & 31 & 62,0 \\
\hline Căng thằng tâm lý. & 34 & 68,0 \\
\hline Mắc các bệnh mạn tính & 29 & 58,0 \\
\hline Tiền sử bệnh trong gia đình & 28 & 56,0 \\
\hline Không biết & 2 & 4,0 \\
\hline
\end{tabular}

NB có kiến thức về yếu tố nguy cơ của bênh THA cao nhất là thừa cân $(72,0 \%)$, thấp nhất là NB không biết về yếu tố nguy cơ THA $(4,0 \%)$

Bảng 3.5: Kiến thức về biến chứng bệnh THA $(n=50)$ 


\begin{tabular}{|c|c|c|}
\hline Biến chứng & $\begin{array}{c}\text { Tân } \\
\text { suất }(\mathbf{n})\end{array}$ & Tỷ lệ \%o \\
\hline Tai biến mạch máu não & 33 & 66,0 \\
\hline Nhồi máu cơ tim & 34 & 68,0 \\
\hline Suy thận & 17 & 34,0 \\
\hline Biến chứng về mắt & 15 & 30,0 \\
\hline Không biết & 2 & 4,0 \\
\hline
\end{tabular}

NB có kiến thức về biền chứng của bênh THA cao nhất là nhồi máu cơ tim(68\%) tai biến mạch máu não $(66,0 \%)$, thấp nhất là NB không biết về biến chứng của bênh THA $(4,0 \%)$

Bảng 3.6: Kiến thức về điều trị THA $(n=50)$

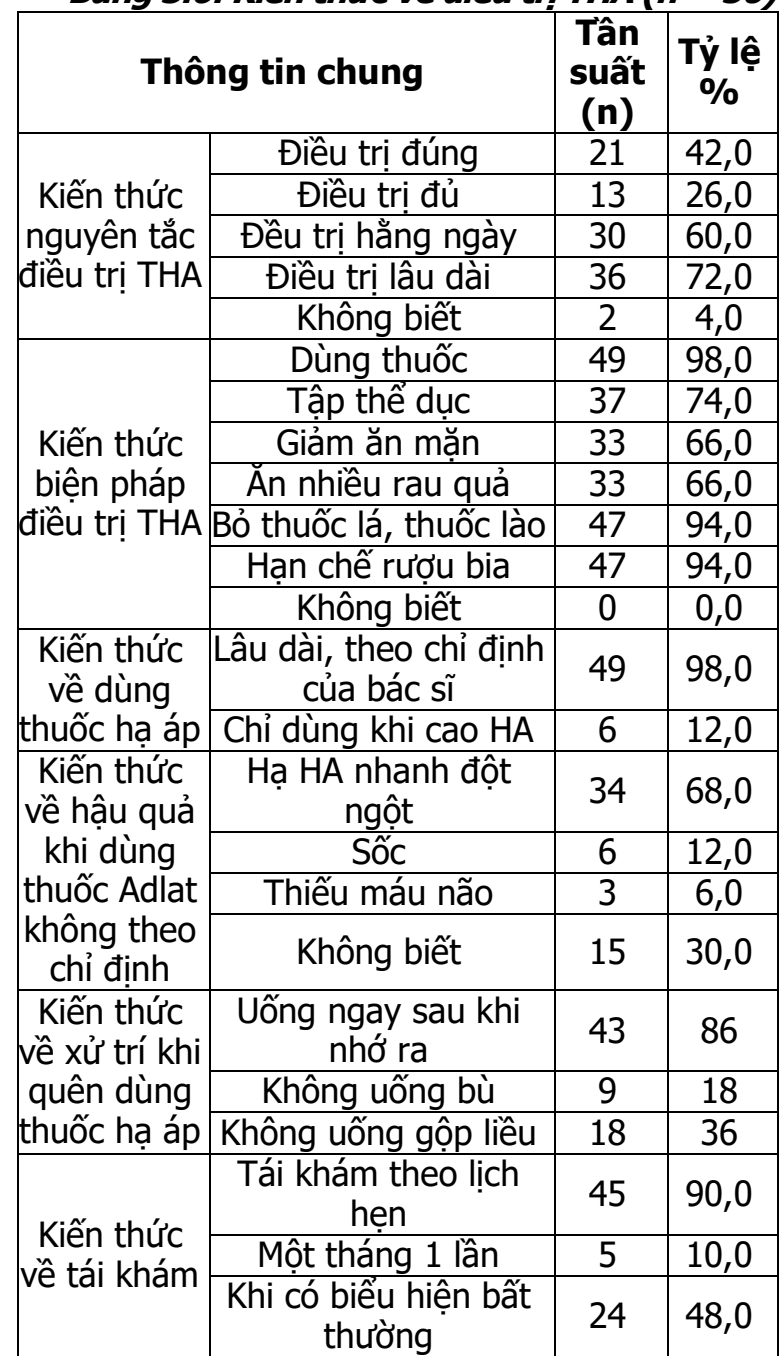

NB có kiến thức về nguyên tắc điều trị THA cao nhất là điều trị lâu dài $(72,0 \%)$, thấp nhất là không biết nguyên tắc điều trị của bệnh THA $(4,0 \%) ; N B$ có kiến thức về biện pháp điều trị THA cao nhất là dùng thuốc $(98,0 \%)$, bỏ thuốc lá, thuốc lào, hạn chế rượu bia $(94,0 \%)$; NB có kiến thức về dùng thuốc hạ áp cho người THA cao nhất là lâu dài, theo chỉ định của bác sĩ
$(98,0 \%)$, NB không có kiến thức về hậu quả khi sử dụng thuốc Adlat không theo chỉ đinh dẫn đến hạ HA nhanh đột ngột cao nhất $(68,0 \%)$, thấp nhất là hậu quả thiếu máu não $(6,0 \%)$, sốc $(12,0 \%)$; NB có kiến thức về xử trí khi quên dùng thuốc hạ áp cao nhất là uống ngay sau khi nhớ ra $(86 \%)$, NB có kiến thức tái khám cao nhất là tái khám theo lịch hẹn $(90 \%)$

\section{BÀN LUẬN}

1. Thực trang GDSK cho NB THA tại bệnh viện Trưởng đại học $Y$ khoa Vinh năm 2020. Kết quả thu được cho thấy tỉ lệ NB THA điều trị tại bệnh viện Trường đại học Y khoa Vinh năm 2020 được nhân viên y tế GDSK cao $(100 \%)$, tỉ lệ bác sĩ tham gia GDSK cho NB (88\%) chiếm tỉ lê cao hơn điều dưỡng $(74 \%)$ và hình thức GDSK chủ yếu là tư vấn cá nhân $(80 \%)$. Thực trạng cho thấy các nhân viên y tế luôn lồng ghép việc GDSK cho NB THA trong quá trình chăm sóc và điêu trị tại bệnh viện tuy nhiên vai trò của người điêuu dưỡng trong công tác GDSK cho NB cần được chú trọng hơn. So với nghiên cứu của Pham Thi Trang (2013) tỉ lê NB THA tại bệnh viện Tim Hà Nội được nhân viên y tế tư vấn GDSK $(64,9 \%)$, có nhưng chưa đầy đủ $(35,1 \%)$. Nghiên cứu của Nguyễn Thái Quỳnh Chi 2018 Kết quả cho thây NB đánh giá điêu dưỡng có thực hiện 8 hoạt động trong nhiệm vụ tư vấn, hướng dẫn GDSK với tỷ lệ từ $67,5-$ $90 \%$; tuy nhiên, qua quan sát thực hành, chỉ có $62,5 \%$ điều dướng được đánh giá "đat" khi thực hiên nhiêm vụ. Yếu tố ảnh hưởng đển việc thực hiện nhiệm vụ tư vấn, hướng dẫn GDSK cho NB của điều dưỡng bao gồm: số lượng NB phải chăm sóc; hoạt động đào tạo, bồi dưỡng kiến thức; và hoạt động kiểm tra, giám sát hỗ trợ.

Về thời điểm GSSK cho NB THA ở cả 3 thời điểm tương đối đồng đều tuy nhiên chưa đạt tî lệ cao. Cụ thể thời điểm GDSK cho NB THA lúc vào viện $(46 \%)$, trong quá trình điều trị $(58 \%)$, trước lúc ra viện (52\%). Nội dung GDSK cho NB THA đạt tỉ lệ cao nhất là hướng dần NB tái khám (92\%), thấp nhất là nguyên nhân (54\%). Thực tế cho thấy hướng dẫn NB tái khám đạt tî lệ cao do NB THA trước khi ra viện có đơn thuốc kê về nhà, nhân viên y tế sẽ dặn tái khám sau khi dùng hết đơn và hầu hết các trường hợp THA đều không rõ nguyên nhân và được gọi là THA vô căn và cao $\mathrm{HA}$ thứ phát là hệ quả của một số bệnh lý như bệnh thận, bệnh tuyến giáp, u tuyến thượng thận hay tác dụng gây ra...

2. Hiệu quả chương trình GDSK cho người bệ̉nh THA tại bệnh viện Trường đại 
học Y khoa Vinh năm 2020. Trong tổng số 50 NB THA được nghiên cứu, NB có kiến thức về trị số $\mathrm{HA}$ tăng, cao nhất là $\mathrm{HA}$ tối đa $\geq 140 \mathrm{mmHg}$ (62\%), HA tối thiểu $\geq 90 \mathrm{mmHg}(20 \%)$, không có NB không biết (0\%); NB có kiến thức về thời điểm đo $\mathrm{HA}$ tại nhà cao nhất là hằng ngày (92\%), không có NB không biết (0\%). So với nghiên cứu của Pham Thị Trang (2013) tỷ lệ NB hiểu đúng chỉ số HA cao chiếm tỷ lệ $42,1 \%$, tỷ lệ người hiểu sai về chỉ số $\mathrm{HA}$ cao hoặc không biết chiếm $57.9 \%$; Tỷ lệ người thường xuyên đo và ghi lại HA của mình chiếm tỷ lê $32.9 \%$, tỷ lệ NB không theo HA thường xuyên là $67.1 \%$. Việc NB thường xuyên đo và ghi lại $\mathrm{HA}$ của mình rât quan trọng cho bác sĩ trong việc điều trị và kiểm soát HA. Theo nghiên cứu của Trương Thị Thùy Dương (2016) số đối tượng nghiên cứu biết số đo HA của bản thân chiểm tỷ lệ rất thấp (chung hai xã là $14,1 \%$, xã đối chứng là $15,1 \%$ và xã can thiệp là 13,2\%). Thực tế cho thấy người dân ở cộng đồng có THA nhưng họ không biết vì vậy họ không phòng chống, không điều trị nên rất dễ xảy ra tai biến.

Kết quả nghiên cứu cho thấy NB có kiến thức về yếu tố nguy cơ của bệnh THA cao nhất là thừa cân $(72 \%)$, sử dụng rượu bia thuốc lá $(66 \%)$, ăn nhiều muối $(6,2 \%)$, thấp nhất là NB không biết về yễu tố nguy cơ THA (4\%). Tỷ lệ biết đúng về các yếu tố nguy cơ của bệnh THA ở NB trong nghiên cứu này cao hơn kết quả nghiên cứu năm 2002 của Phạm Gia Khải và cộng sự điều tra 5.012 người từ 25 tuổi trở lên tại 4 tỉnh miền Bắc Việt Nam (Nghê An, Hà nội, Thái Bình và Thái Nguyên), tỷ lệ biết đúng của nghiên cứu đó chỉ là $23 \%$. Sở dĩ có sự chênh lệch đó là do $100 \%$ NB đến khám được nhân viên y tế tư vấn. Trong các yếu tố nguy cơ trên thì thừa cân, thói quen ăn mặn, uống nhiều rượu, bia được NB biết đến nhiều bởi lẽ NB điều trị tại bệnh viện đã được tư vấn, kê đơn và dặn dò trong mỗi lần đến khám bệnh hàng tháng.

Nghiên cứu của chúng tôi cho thấy NB có kiến thức về biến chứng của bệnh THA cao nhất là nhồi máu cơ tim $(68 \%)$ tai biến mạch máu não (66\%), suy thận (34\%), mắt (30\%) thấp nhất là NB không biết về biến chứng của bệnh THA (4\%). Tỷ lệ NB biết đến các tai biến của THA gây ra tương đương với tỷ lệ hiểu biết về các yếu tố nguy cơ. Trong phần tư vấn của nhân viên y tế thường trọng vấn về các yếu tố nguy cơ nhiều hơn để mong muốn NB thay đổi hành vi lối sống, phối hợp với việc dùng thuốc để việc điều trị, kiểm soát HA tốt. So với nghiên cứu của Pham Thị Trang cho thấy tỷ lệ NB biết về các tai biến của THA khi không điều trị hoặc điều trị chưa đạt hiệu quả là thấp hơn; nguy cơ tai biến mạch máu não chiếm $63.3 \%$, nhồi máu cơ tim $57.8 \%$, suy tim $72,0 \%$, giảm thị lực $55.9 \%$, tai biến suy.

Về nguyên tắc điều trị THA $72 \%$ NB có kiến thức về nguyên tắc điều trị THA là điều trị lâu dài, 4\% NB không biết nguyên tắc điều trị của bệnh THA; $98 \%$ NB có kiến thức về biện pháp điêu trị THA cao nhất là dùng thuốc, $94 \%$ bỏ thuốc lá, thuốc lào, hạn chế rượu bia; không có NB không biết biện pháp điều trị của bệnh THA $(0 \%)$. Theo nghiên cứu của Phạm Thùy Trang tỷ lệ NB hiểu biết về các biện pháp không dùng thuốc làm giảm HA: Ngừng hút thuốc lá $64,9 \%$, ngừng hút thuốc lào $64,9 \%$, bỏ thói quên ăn mặn $98,2 \%$, giảm cân $71,8 \%$, không dùng rượu bia, chất kích thích 85,9\%, tập thể dục thường xuyên 95,5\%, tránh căng thẳng trong cuộc sống $100 \%$.

Kết quả nghiên cứa của chúng tôi cho thây NB có kiến thức về chế độ dinh dưỡng cho người THA cao nhất là hạn chể: chất béo, muối, rượu bia, thuốc lá, chất kích thích (100\%), không có NB không biết (0\%). Nghiên cứu của Nguyễn Thị Thùy Dương 2016 Tỷ lệ đối tượng nghiên cứu biết THA có thể dự phòng được chung hai xã thuộc huyện Lục Bình - Hà Nam là 66,8\%, xã đối chứng $76,2 \%$ và $59,0 \%$ ở xã can thiệp, trong đó, số người biết biện pháp ăn giảm chất béo chiếm tỷ lệ cao nhất (chung hai xã là 19,7\%, xã đối chứng là $22,9 \%$, xã can thiệp là 18,3\%), thấp nhất là biện pháp tránh căng thẳng thần kinh (chung hai xã là 2,7\%, xã đối chứng là 4,8\%, xã can thiệp là 1,0\%).

Về kiến thức xử trí khi quên dùng thuốc hạ áp NB có kiến thức về xử trí khi quên dùng thuốc hạ áp cao nhất là uống ngay sau khi nhớ ra $(86 \%)$,

Về kiến thức tái khám: có $90 \%$ NB THA có kiến thức tái khám theo lịch hẹn và không có NB nào không biết. Theo nghiên cứu của Phạ Thế Xuyên tỉ lệ tham gia điều trị THA của các ĐTNC bị THA ở hai xã can thiệp và đối chứng là khá cao, lân lượt là $90 \%$ và $92,8 \%$. Tuy nhiên, tỷ lệ tuân thủ điều trị lại đạt khá thấp, chỉ đạt lần lượt là $26,4 \%$ và $23,4 \%$. Không có sự khác nhau về tham gia và tuân thủ điều trị THA ở hai xã. So với nghiên cứu của Phạm Thị Trang tất cả NB đều tuyệt đối tuân thủ y lệnh bác sĩ, không tự thay đổi thuốc mà không hỏi y kiến của bác sĩ, tái khám theo hẹn của bác sĩ, biết khám lại ngay khi có dấu hiệu bất thường. Về kiến thức dùng thuốc, NB uống thuốc đều đặn theo đơn của bác sĩ. Không có trường hợp nào trả lời chỉ uống 
thuốc khi huyết cao hay chỉ uống khi có dấu hiệu của THA (đau đâu, chóng mặt, hoa mắt...).

\section{KẾT LUÂ̂N}

1. Thực trạng giáo dục sức khỏe cho người bệnh tăng huyết áp tại bệnh viện Trường đại học Y khoa Vinh năm 2020

- 100\% người bệnh tăng huyết áp được nhân viên y tế giáo dục sức khỏe với tư vấn cá nhân $(80 \%)$ và tài liệu phát tay $(72 \%)$.

- 70,4\% người bệnh được tư vấn, giáo dục sức khỏe phù hợp với bệnh khi vào viện, trong quá trình điêuu trị và lúc ra viện

- 81,5\% nhân viên đánh giá bệnh viện không tiến hành đánh giá (hoặc nghiên cứu) hiệu quả hoạt động truyên thông, giáo dục sức khỏe cho người bệnh.

2. Hiệu quả chương trình giáo dục sức khỏe cho người bệnh tăng huyết áp tại bệnh viện Trường đại học $Y$ khoa Vinh

- Đa số người bệnh có kiến thức về bệnh THA như biểu hiện, trị số huyết áp, thời điểm đo huyết áp bệnh THA

- 72\% người bệnh có kiến thức về nguyên tắc điều trị THA là điều trị lâu dài,

- Chỉ có 4\% người bệnh không biết nguyên tắc điều trị của bệnh THA

- 90\% người bệnh THA có kiến thức tái khám theo lịch hẹn

TÀI LIẸU THAM KHẢO

1. Hội tim mạch Việt Nam (2018), "Khuyến cáo về chẩn đoán điều trị \& dư phòng THA". Trang web http://vnha.org.vn/data/Khuyen-Cao-THA-2018, truy câp ngày 20/3/2020

2. Cục y tế dự phòng, Bộ Y tế (2015), "THA, kẻ giết người thiâm lă̆ng"

3. Tan Van Bui, Christopher Leigh Blizzard., Khue Ngoc Luong, Ngoc Le Van Truong, Bao Quoc Tran, Petr Otahal, Mark R.Nelson Seana Gall. and and at el (2016), "National survey of risk factors for noncommunicable disease in Vietnam: prevalence estimates and an assessment of their validity", BMC Public Health, Volume 16, pp.489.

4. Nguyễn Thái Quỳnh Chi (2018) tạp chí khoa học tập 3 số 2-2019. Đánh giá việc thực hiên nhiệm vụ tư vấn, hướng dẫn GDSK cho bênh nhẩn Khoa Nội Tim mạch-Lão học, Bệnh viện đa khoa tỉnh Khánh Hòa năm 2018

5. Trương Thị Thùy Dương (2016) Hiêuu quả của mô hình truyền thông giáo dục dinh dưỡng nhằm cải thiên môt số yếu tố nguy cớ THA tai công đồng

6. Trân Thị Hằng Nga (2018), "đánh giá hoạt động GDSK của người điều dưỡng bệnh viện đa khoa tỉnh Quảng Trị và một số yếu tố liên quan, năm 2018", Khoa học điều dưỡng tập 1 (số 3 2018)

7. Carlo Marra., Karissa Johnston. and Valerie Santschi (2017), "Cost-effectiveness of pharmacist care for managing hypertension in Canada", Canada Pharmacists Jounal, Volum 150(3), pp.184-197.

\section{KẾT QUẢ PHẪU THUÂT ĐÎ̀̂U TRI BONG VÕNG MẠC CO KÉO DO ĐÁI THÁO ĐƯờNG CÓ SỬ DỤNG PFCL}

\section{TÓM TẮT.}

Mục tiêu: đánh giá kết quả phẫu thuật điều trị bong võng mạc co kéo do đái tháo đường (ĐTĐ) có sử dụng dung dịch Perfluorocarbon (PFCL). Đối tượng và phương pháp nghiên cứu: nghiên cứu can thiệp lâm sàng không đối chứngtrên 21 bệnh nhân (21 mắt) bị bong võng mạc co kéo do ĐTĐ. Kết quả: tại thời điểm 3 tháng sau phẫu thuật, tỷ lệ võng mạc áp là95,2\% (20/21 ca) thị lực cải thiện so với trước mổ có ý nghĩa thống kê $p<0,001$; các biến chứng gặp sau mổ là: tăng nhãn áp sau 2 ngày $2 \mathrm{ca}$, xuất huyết dịch kính: 2ca, 1 ca xuất hiện màng trước võng mạc. Có sự

\footnotetext{
${ }^{1}$ Trường Đại học Y Hà Nội

²Bênh viện Mắt Trung Ương

Chịu trách nhiệm chính: Vũ Tuấn Anh

Email: vta.oph@gmail.com

Ngày nhận bài: 11.8 .2021

Ngày phản biện khoa học: 5.10.2021

Ngày duyệt bài: 14.10.2021
}

Trần Đăng Quang ${ }^{1}$, Vũ Tuấn Anh ${ }^{2}$

khác biệt về kết quả phục hồi về giải phẫu và chức năng giữa nhóm bong qua hoàng điểm và chưa qua hoàng điểm. Kết luận: phẫu thuật cắt dịch kính điêu trị bong võng mạc co kéo do ĐTĐ có sử dụng PFLC giải phóng mù lòa và khắc phục được biến chứng giai đoạn cuối, nhằm cứu vãn thị lực dù còn thấp cho bệnh nhẩn ĐTĐ biến chứng

Tư khóa: bong võng mạc co kéo do ĐTĐ, cắt dịch kính, PFCL

\section{SUMMARY \\ RESULTS OF VITRECTOMY USING PFCL FOR TREATMENT OF DIABETIC \\ TRACTIONALRETINAL DETACHMENT}

Aims: results of surgery using PFCL for treatment ofdiabetictractional retinal detachment. Methods: interventional cases series. Patients received an Avastinintravitreal injection prior to undergoing vitrectomy to remove hemorrhage, traction and reattach the retina. Results: for 21 cases, results 3 months after surgery: $95,2 \%$ of cases retinal re- 
attached (20/21), visual recovery. Complications as high IOP, vitreous hemorrhage, secondảy epiretinal membrane. Conclusion: vitrectomy using PFCL for treatment ofdiabetic tractional retinal detachment have good outcomes for anatomical and visual recovery,prevent blindness and savevision for patients with complicated diabetic.

Keywords: diabetic tractional retinal detachment, vitrectomy, PFCL

\section{I. ĐĂT VẤN ĐỀ}

Bong võng mac (BVM) co kéo là biến chứng nặng của bệnh võng mạc đái tháo đường (ĐTĐ) giai đoạn tăng sinh, có nguy cơ đe dọa mất thị lực đứng hàng đầu. Tỷ lệ mắc bệnh có xu hướng ngày càng tăng tuy nhiên điều trị BVM co kéo cho đến nay vẫn còn là thách thức trong nhãn khoa.

Phẫu thuât cắt dich kính điều trị BVM co kéo do bênh ĐTĐ̇ đòi hỏi phải loại bỏ tối đa các co kéo dịch kính võng mac tạo điều kiện cho võng mạc áp trở lại.Cùng với nghiên cứu sự tiến bộ về kỹ thuật và ứng dụng các chất liệu dùng trong phẫu thuât đặc biêt là dung dịch perfluorocarbon (PFCL) đã đem laai những tiến bộ vượt bậc trong điều trị BVM. Trên thế giới, năm 1982 Haidt đã thử nghiệm PFCL như là một chất độn trong buồng dịch kính, năm 1987 Chang và cộng sự đã sử dụng $\mathrm{PFCL}$ trong phẫu thuật dịch kính trên bệnh nhân BVM có tăng sinh dịch kính võng mạc trầm trọng ${ }^{1,2}$. Nhờ các đặc tính đặc biệt kể trên, PFCL có ưu điểm rất lớn trong việc giữ cố định võng mạc trong quá trình cắt dịch kính, trải phẳng các nếp gấp và vùng võng mạc bong, qua đó bóc tách các màng tăng sinh, giải phóng co kéo trước-sau và co kéo ngang dễ dàng hơn, tháo dịch dưới võng mạc tránh phải mở võng mạc vùng hậu cực, giảm năng lượng laser khi quang đông toàn võng mạc, do đó rút ngắn thời gian phẫu thuật và đem lại kết quả cao trong điều trị BVM co kéo. Tuy nhiên chưa có nghiên cứu nào đánh giá về kết quả của can thiệp này ở Việt Nam. Vì vầy chúng tôi tiến hành nghiên cứu: "Phẫu thuâtt cằt dịch kính điều tri bong vông mạc co kéo do đái tháo đường có sừ dụng dung dịch perfluorocarbon"

\section{II. ĐỐI TƯỢNG VÀ PHƯƠNG PHÁP NGHIÊN CỨU}

Nghiên cứu được tiến hành trên nhóm bênh nhân bi BVM co kéo do ĐTĐ có chỉ định phẫu thuật tại Bệnh viện mắt TW từ tháng $8 / 2020$ đến tháng $5 / 2021$.

Tiêu chuẩn lựa chơn bênh nhân: bênh nhân bị BVM co kéo do ĐTĐ, có chỉ định phẫu thuật cắt dịch kính

Thiêt kế nghiên cứu: nghiên cứu can thiệp lâm sàng không đối chứng, cỡ mẫu là21bệnh nhân. Số liệu được xử lý và phân tích bằng chương trình thống kê SPSS 16.

Các bước tiến hành nghiên cứu. Bệnh nhân BVM co kéo do ĐTĐ nhập viện được khám, làm hồ sơ bệnh án, đo thị lực nhìn xa với kính và không kính, đo nhãn áp, đánh giá tình trạng giác mạc, thủy tinh thể, khám đáy mắt bằng kính 3 mặt gương Goldmann hoặc đèn soi Schepens kết hợp kính + 20D đánh giá tình trạngBVM, dịch kính, vị trí - số lượng - đặc điểm tăng sinh co kéo...

Tiêm Avastin liều $1,25 \mathrm{mg} / 0,05 \mathrm{ml}$ vào buồng dịch kính trước phẫu thuật 5-7 ngày

Quy trình phẫu thuật: bệnh nhân được gây tê cạnh nhãn cầu, với những trường hợp còn thủy tinh thể (TTT) có chỉ định phẫu thuật thay TTT kèm theo cắt dịch kính. Dùng đầu cắt $23 \mathrm{G}$ cắt dịch kính từ trung tâm ra ngoại biên. Bớm từ từ vào nội nhãn $1 \mathrm{ml}$ đến $5 \mathrm{ml}$ dung dịch $\mathrm{F}$ Decalin, bắt đầu từ vùng gai thị, kỹ thuật bơm 1 bóng $\mathrm{F}$ - Decalin sao cho dung dịch trải đều vùng võng mạc hậu cực, tránh làm vỡ thành nhiều giọt nhỏ, chú ý không để dung dịch F- Decalin chui qua vết rách (nếu có) vào dưới võng mạc. Sau khi võng mạc được trải và cố định dưới dung dịch $\mathrm{F}$-Decalin, tiến hành bóc màng tăng sinh sơ giải phóng co kéo trước-sau và co kéo tiếp tuyến, cắt sạch dịch kính còn sót lại và hút dịch dưới võng mạc qua vết rách VM (nếu có) hoặc mở VM ngoại vi. Sau đó tiến hành laser bao quanh vết rách, laser quang đông toàn võng mạc, trao đổi khí dịch với áp lực khí $30 \mathrm{mmHg}$, cuối cùng là thì hút sạch dung dịch $\mathrm{F}$-Decalin và đóng vết mổ kèm theo bơm 0,5 đến $0,7 \mathrm{ml}$ khí nở $\mathrm{C}_{3} \mathrm{~F}_{8}$ hoặc dầu silicone.

Đánh giá sau phẫu thuât :Bênh nhân sau phẫu thuật bơm khí hoặc dầu silicone phải nằm sấp 7-14 ngày đầu. Trong những ngày nằm viện bệnh nhân được theo dỗi các diễn biến về thị lực, nhãn áp, tình trạng võng mạc và các biến chứng có thể xảy ra như xuất huyết tiền phòng, xuất huyết dịch kính, tăng nhãn áp...Sau khi ổn định bệnh nhân được ra viện và tái khám định kỳ sau 1 tuần, 1 tháng và 3 tháng. Các chỉ tiêu đánh giá mối lần khám lại:

- Thị lực nhìn xa có và không chỉnh kính, nhãn áp đo bằng nhãn áp kế Goldmann

- Khám sinh hiển vi đánh giá bán phần trước, tình trang võng mạc áp sau phẫu thuật

- Từ lần khám sau 1 tháng trở đi bệnh nhân sẽ được làm thêm chụp OCT hoàng điểm.

\section{KẾT QUẢ NGHIÊN CỨU VÀ BÀN LUÂN}

1. Đặc điểm đối tượng nghiên cứu. Trong 21 bệnh nhân nghiên cứu có 16 nam 
chiếm 76,2\%, nữ là 5 bệnh nhân chiếm 23,8\%. Tuổi trung bình của nhóm nghiên cứu là $58,9 \pm 12,7$, trong đó độ tuổi $<40$ tương ứng với những bệnh nhân mắc ĐTĐ typ 1 có 3 bệnh nhân (14,3\%), độ tuổi $\geq 40$ tương ứng với nhóm bệnh nhân ĐTĐ typ 2 có 18 bệnh nhân $(85,7 \%)$. Thời gian phát hiện ĐTÐ trung bình $12 \pm 4$ năm, chủ yếu là nhóm bệnh nhân có thời gian phát hiện $Đ T Ð \geq 10$ năm với 15 bệnh nhân $(71,4 \%)$, nhóm < 10 năm có 6 bệnh nhẩn $(28,6 \%)$.

\section{Kết quả phẫu thuâtt}

Kết quả về mặt giải phẫu: bệnh nhân có tình trạng võng mạc áp tốt tại thời điểm ra viện và khám lại sau 1 tuần là $100 \%$. Tại thời điểm 1 tháng, tỷ lệ bệnh nhân có tình trạng võng mạc áp tốt là $85,7 \%$ (18/21), võng mạc không áp là
14,3\% (3/21). Có 3 bệnh nhân BVM một phần tại thời điểm 1 tháng, trong đó có 2 bệnh nhân còn dịch dưới võng mạc phát hiện qua soi đáy mắt và trên phim chụp $O C T, 1$ bệnh nhân bong võng mạc cao do xuất hiện vết rách thứ phát. Bệnh nhân này đã được phẫu thuật cắt dịch kính và bơm dầu silicon nội nhãn, tiếp tục theo dõi sau 3 tháng. Tại thời điểm 3 tháng, tỷ lệ võng mạc áp tốt 95,2\% (20/21), vẫn còn 1 trường hợp còn dịch dưới võng mạc $4,8 \%(1 / 21)$, nguyên nhân là võng mạc bong lâu ngày xơ hóa, dịch dưới võng mạc sau cần thời gian để hấp thu thông qua qua biểu mô sắc tố, chúng tôi không tiến hành can thiệp thêm. Tỳ lệ võng mạc áp thành công sau phẩu thuật tương tự với các tác giả ngoài nước cũng khá cao trên $85 \%^{3,4,5}$.

\section{Kêt quả về mặt thị lực:}

\begin{tabular}{|c|c|c|c|c|c|c|}
\hline Thị lực & $\begin{array}{c}\text { ST(+)- } \\
\text { ĐNT<1m }\end{array}$ & $\begin{array}{c}\text { ĐNT1m- } \\
\text { ĐNT<3m }\end{array}$ & $\begin{array}{c}\text { ĐNT3m- } \\
\mathbf{< N 2 0 / 2 0 0}\end{array}$ & $\begin{array}{c}\mathbf{2 0 / 2 0 0 -} \\
\mathbf{< 2 0 / 6 0}\end{array}$ & $\begin{array}{c}\mathbf{2} \\
\mathbf{2 0 / 6 0}\end{array}$ & Tổng \\
\hline Trước PT & $71,4 \%$ & $14,3 \%$ & $9,5 \%$ & $4,8 \%$ & 0 & $100 \%$ \\
\hline Sau PT 3 tháng & $23,8 \%$ & $28,6 \%$ & $33,3 \%$ & $9,5 \%$ & $4,8 \%$ & $100 \%$ \\
\hline
\end{tabular}

Đã có sự cải thiện đáng kể về thị lực tại thời điểm sau phẫu thuật 3 tháng so với trước khi phẫu thuật. Thị lực được quy đổi sang tham chiếu logMAR để đánh giá sự thay đổi chính xác nhất cho dù thị lực chỉ cải thiện được một hàng. Trước phẫu thuật đa phần bệnh nhân có thị lực rất thấp dưới ĐNT $5 \mathrm{~m}$. Thị lực trung bình trước phẫu thuâtt theo logMAR là $2,02 \pm 0,5$. Do sau khi cắt dịch kính điều trị BVM, bệnh nhân được bơm khí nở vào buồng dịch kính để làm áp võng mạc và tạo điều kiện cho quá trình viêm dính sẹo laser vết rách võng mạc, nên khi khám lại tại các thời điểm 1 tuần và 1 tháng sau phẫu thuật, sự thay đổi về mặt thị lực chưa có ý nghĩa do vẫn còn bóng khí. Chỉ ở thời điểm 3 tháng sau phẫu thuật, khi bóng khí nở hoàn toàn tiêu hết, thị lực bệnh nhân được cải thiện, với giá trị trung bình theo $\log M A R$ là $1,48 \pm 0,4$. Sự khác biệt này có ý nghĩa thống kê với $p<0,001$.

Biến chứng sau phẫu thuật: Theo nghiên cứu ghi nhận có 5 trường hợp xảy ra biến chứng trong quá trình theo dõi $(23,8 \%)$, và 16 trường hợp không xảy ra biến chứng (76,2\%). Trong đó:

- Biến chứng tăng nhãn áp xuất hiên trên 2 bệnh nhân ở thời điểm 2 ngày sau phẫu thuật. Thăm khám không thây có biểu hiện viêm bán phân trước, IOL và mống mắt hoàn toàn bình thường, võng mạc áp dưới bóng khí nở, soi góc tiền phòng mở và không có dính góc. Nguyên nhân có thể do tốc độ nở bóng khí nội nhãn vượt quá khả năng bù trừ của đường thoát thủy dịch.

- 2 trường hợp xuất huyết dịch kính không

cần phải phẫu thuật lại. Tỷ lệ xuất huyết dịch kính sau phẫu thuật BVM co kéo theo các báo cáo trước đây dao động từ 5 đến $55 \%{ }^{6,7,8}$. Xuất huyết dịch kính sau phẫu thuật thường gặp ở những trường hợp BVM co kéo phức tạp, cần đòi hỏi bóc tách các co kéo rộng gây tổn thương võng mạch cùng các mạch máu6,8, ngoài ra việc kiểm soát đường huyết kém cũng là yếu tố nguy cơ cao gây biến chứng này ${ }^{6}$. Xuất huyết có thể từ tân mạch còn sót lại, các mạch máu vỡ trong quá trình phẫu thuật, hoặc từ tẩn mạch mới xuất hiện ${ }^{8}$. Chúng tôi cho rằng việc tiêm Avastin trước phẫu thuật 5-7 ngày đã làm giảm đáng kể tỷ lệ biến chứng xuất huyết dịch kính sau mồ.

- 1 trường hợp xuất hiện màng trước võng mạc tại thời điểm 3 tháng sau phẩu thuật phát hiện trên phim chụp OCT, các yếu tố nguy cơ hình thành màng trước võng mạc như màng $x$ ơ mạch, màng dịch kính sau bám chắc vào võng mạc không thể bóc tách hoàn toàn trong quá trình phẫu thuật, xuất huyết dịch kính sau phẫu thuật ${ }^{9}$. Đây cũng là 1 nguyên nhân khiến thị lực bệnh nhân không cải thiện sau phẫu thuật.

- Ngoài ra các biến chứng khác các đề cập đến trong y văn như: còn sót $P F C L$ nội nhãn, bong hắc mạc, glôcôm tân mạch hay teo nhãn cầu chúng tổi không gặp ở các trường hợp trong nghiên cứu này 3,5 ,

3. Các yếu tố liên quan đến kết quả phẫu thuật

Mức độ bong vông mạc liên quan đến kêt quả giải phầu: 


\begin{tabular}{|c|c|c|c|}
\hline $\begin{array}{c}\text { Tình trạng VM } \\
\text { Mức độ bong }\end{array}$ & $\begin{array}{c}\text { Võng } \\
\text { mạc áp } \\
\text { tốt }\end{array}$ & $\begin{array}{c}\text { Võng } \\
\text { maac } \\
\text { khống áp }\end{array}$ & Tổng \\
\hline Chưa qua hoàng điếm & $92,9 \%$ & $7,1 \%$ & $100 \%$ \\
\hline Qua hoàng điếm & $71,4 \%$ & $28,6 \%$ & $100 \%$ \\
\hline Tống & $\mathbf{8 5 , 7 \%}$ & $\mathbf{1 4 , 3 \%}$ & $\mathbf{1 0 0} \%$ \\
\hline
\end{tabular}

Tỷ lệ võng mạc áp tốt ở nhóm chưa bong qua hoàng điểm là $92,9 \%$. Ở nhóm bong qua hoàng điểm tỷ lệ này là $71,4 \%$. Tỷ lệ thành công thấp hơn theo nhiêu nghiên cứu cho rằng do võng mạc bong lâu ngày quá trình xơ hóa của võng mạc làm cho võng mạc khó áp lại sau mổ.

Mức độ bong võng mạc liên quan đến kết quả thị lực:
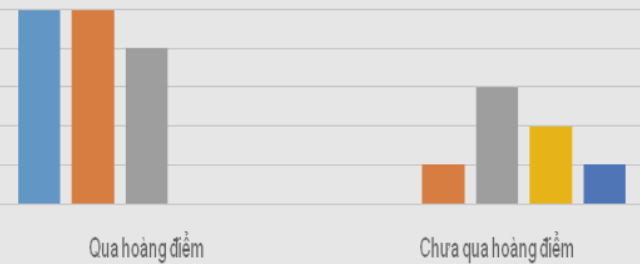

IST $++\mid-<\theta N T 1 m \quad\|\theta N T 1 m-<\theta N T 3 m \quad\| \theta N T 3 m-<20 / 200 \quad \| 20 / 200-20 / 60 \quad$ \} \geq 2 0 / 6 0

Thị lực theo các nhóm được quy ra giá trị log Mar

\begin{tabular}{|c|c|c|}
\hline $\begin{array}{c}\text { Mức độ bong } \\
\text { võng mạc }\end{array}$ & $\begin{array}{c}\text { Bong qua } \\
\text { hoàng điểm }\end{array}$ & $\begin{array}{c}\text { Bong chưa qua } \\
\text { hoàng điểm }\end{array}$ \\
\hline $\begin{array}{c}\text { Thị lực trung bình } \\
\text { theo logMAR }\end{array}$ & $1,68 \pm 0,3$ & $1,09 \pm 0,3$ \\
\hline
\end{tabular}

Sự khác biệt về thị lực của nhóm BVM qua hoàng điểm và chưa qua hoàng điểm có ý nghĩa thống kê với $p<0,05$. Hoàng điểm tập chung nhiều tế bào nón, đảm đương chức năng thị giác cao nhất và chức năng sắc giác, BVM qua hoàng điểm là một biến chứng nặng, đe dọa thị lực trầm trọng, cho dù kết quả giải phẫu tốt nhưng quá trình bong lâu ngày khiến võng mạc vùng hoàng điểm không được nuôi dưỡng, sự chết dần của các tế bào quang cảm thụ ánh sáng dẫn đến kết quả thị lực phục hồi kém.

Diện tích màng tăng sinh co kéo võng mạc liên quan kết quả giải phẫu :

Tinh trạng vông mạc theo các nhóm

\begin{tabular}{|c|c|c|c|}
\begin{tabular}{|c|c|} 
Tình trạng VM \\
Diện tî́ch màng \\
tang sinh
\end{tabular} & $\begin{array}{c}\text { Võng } \\
\text { mác áp } \\
\text { tốt }\end{array}$ & $\begin{array}{c}\text { Võng } \\
\text { mạc } \\
\text { không áp }\end{array}$ & Tổng \\
\hline$<2$ cung phần tư' & $100 \%$ & $0 \%$ & $100 \%$ \\
\hline $\begin{array}{c}<=2 \text { cung phần } \\
\text { tứ }\end{array}$ & $72,7 \%$ & $27,3 \%$ & $100 \%$ \\
\hline Tống & $\mathbf{8 5 , 7 \%}$ & $\mathbf{1 4 , 3 \%}$ & $\mathbf{1 0 0 \%}$ \\
\hline
\end{tabular}

Tất cả những bệnh nhân có diện tích màng tăng sinh co kéo võng mạc dưới 2 cung phần tư trở xuống đều có kết quả giải phẫu võng mạc áp tốt ở các thời điểm khám lại sau 1 tháng và 3 tháng. Ở nhóm diện tích màng tăng sinh từ 2 cung phần tư trở lên, $72,7 \%$ bệnh nhân có võng mạc áp tốt sau phẫu thuật, $27,3 \%$ bệnh nhân còn bong võng mạc. Sự khác biệt giữa 2 nhóm bệnh nhân có diện tích màng tăng sinh co kéo võ̉ng mạc trên và dưới 2 cung phần tư có ý nghĩa thống kê với $\mathrm{p}<0,05$. Nhóm bệnh nhân diện tích màng tăng sinh dưới 2 cung phần tư có kểt quả võng mạc áp tốt hơn nhóm từ 2 cung phần tư trở lên. Kết quả này là hợp lý do quá trình bóc tách màng tăng sinh rộng, giải phóng co kéo võng mạc, thậm chí phải cắt 1 phần võng mạc gây ra các tổn thương trên võng mạc, tăng tỉ lệ xuất hiện các vết rách thứ phát, có thể bỏ sót trong phẫu thuật. Ngoài ra bản thân với màng tăng sinh rộng cũng khó bóc tách triệt để, màng còn sót lại gây ra các co kéo thứ phát, làm võng mạc khó áp trở lại hơn.

Tình trạng bong dịch kính sau liên quan đến kết quả giải phấu:

\begin{tabular}{|c|c|c|c|}
\hline $\begin{array}{r}\text { Tình trạng võng } \\
\text { mạc } \\
\text { Tình trạng } \\
\text { bongdịch kính saut }\end{array}$ & $\begin{array}{c}\text { Võng } \\
\text { mác áp } \\
\text { tốt }\end{array}$ & $\begin{array}{c}\text { Võng } \\
\text { mạc } \\
\text { khống } \\
\text { áp }\end{array}$ & Tổng \\
\hline Bong một phần & $80 \%$ & $20 \%$ & $100 \%$ \\
\hline Bong hoàn toàn & $100 \%$ & 0 & $100 \%$ \\
\hline Tống & $85,7 \%$ & $14,3 \%$ & $100 \%$ \\
\hline
\end{tabular}

Tất cả những bênh nhân bong dịch kính sau hoàn toàn cho kết quả võng mạc áp tốt $100 \%$ sau khám lại. ở nhóm bênh nhân bong dịch kính sau 1 phần hoặc chưa bong dịch kính sau tỷ lệ này là $80 \%$. Sự khác biệt giữa 2 nhóm này có ý nghĩa thống kề $\mathrm{p}<0,05$. Trong phẫu thuật cắt dich kính, dịch kính sau chưa bong hoăc bong không hoàn toàn là một thách thức. Nguy cơ sót dịch kính trong quá trình phẫu thuật rất cao, tạo điều kiện cho tăng sinh dịch kính võng mạc sau phẫu thuật, BVM tái phát, các tăng sinh trước hoặc dưới võng co kéo mạc khiến võng mạc khó áp trở lại hơn.

Tình trạng bong dịch kính sau liên quan đên kêt quả thị lực

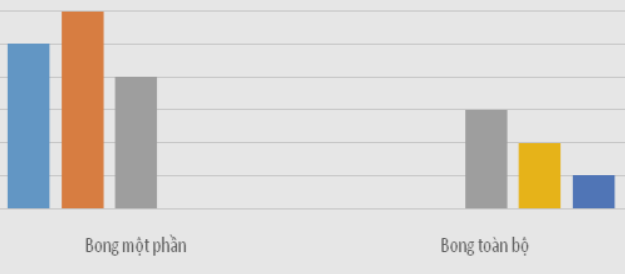

แ $S T(+)-<\ominus N T 1 m \quad\|\ominus N T 1 m-<\ominus N T 3 m \quad\| \ominus N T 3 m-<20 / 200 \quad\|20 / 200-20 / 60 \quad\| \geq 20 / 60$ 
Thi lức trung binh của hai nhóm theo $\log M A R$

\begin{tabular}{|c|c|c|}
\hline $\begin{array}{c}\text { Tình trạng dịch } \\
\text { kính sau }\end{array}$ & $\begin{array}{c}\text { Bong } \\
\text { toàn bộ }\end{array}$ & $\begin{array}{c}\text { Bong 1 } \\
\text { phần }\end{array}$ \\
\hline $\begin{array}{c}\text { Thị lực trung bình } \\
\text { theo logMAR }\end{array}$ & $\begin{array}{c}1,67 \pm \\
0,3\end{array}$ & $1,02 \pm 0,3$ \\
\hline
\end{tabular}

Sự khác biệt về thị lực của 2 nhóm là có ý nghĩa thống kể với $p=0,001<0,05$. Khi dịch kính sau còn sót lại, tạo điêu kiện cho tăng sinh dịch kính võng mạc sau phẫu thuật và kết quả có thể tạo thành màng trước võng mạc, tăng sinh trước và dưới võng mạc, võng mạc khó áp trở lại. Thị lực tiên lượng ở nhóm này sẽ thấp hơn nhóm có bong dịch kính sau hoàn toàn.

Chất độn nội nhãn liên quan đến kêt quả giải phấu:

\begin{tabular}{|c|c|c|c|}
$\begin{array}{c}\text { Tình trạng } \\
\text { vãng mạc } \\
\text { Chất đợn } \\
\text { nội nhãn }\end{array}$ & $\begin{array}{c}\text { võng } \\
\text { mạc áp } \\
\text { tốt }\end{array}$ & $\begin{array}{c}\text { Võng mác } \\
\text { không áp }\end{array}$ & Tổng \\
\hline C3F8 & $92,9 \%$ & $7,1 \%$ & $100 \%$ \\
\hline Dầu Silicon & $71,4 \%$ & $28,6 \%$ & $100 \%$ \\
\hline Tổng & $85,7 \%$ & $14,3 \%$ & $100 \%$ \\
\hline
\end{tabular}

Bệnh nhân sử dụng khí C3F8 cho kết quả võng mạc áp tốt $92,9 \%$ sau khám lại 1 và 3 tháng. Ở nhóm bệnh nhân sử dụng dầu silicon tỷ lệ này là $71,4 \%, 28,6 \%$ võng mạc không áp. Tỷ lệ võng mạc áp thấp hợn tại nhóm sử dụng dầu Silicon có thể giải thích do dầu Silicon thường được sử dụng trong các trường hợp co kéo võng mạc phức tạp mà phẫu thuật khổng thể loại bỏ hoàn toàn được, cần chèn ép lâu dài tạo điều kiện cho võng mạc áp trở lại; hoặc những trường hợp kèm theo rách võng mạc phía dưới, bệnh nhân khó khăn trong việc duy trì tư thế sau phẫu thuật. Sức căng bề mặt của khí/nước cao hơn so với dầu silicon/nước (70erg/cm2 so với 50 erg/cm2), điều này cũng lý giải được tỷ lệ thành công của khí nở C3F8 luôn cao hơn dầu silicon ${ }^{8,9}$.

Chất độn nội nhãn liên quan đến kêt quả thị lực:

\begin{tabular}{|c|c|c|}
\hline Chất độn & C3F8 & Dâu Silicon \\
\hline $\begin{array}{c}\text { Thị lực trung } \\
\text { bình (logMAR) }\end{array}$ & $1,26 \pm 0,3$ & $1,91 \pm 0,15$ \\
\hline
\end{tabular}

Sự khác biệt về thị lực của 2 nhóm này là có ý nghĩa thống kê với $P<0,05$. Theo $y$ văn dầu Silicon nội nhãn là 1 yếu tố nguy cơ dẫn đến việc thị lực phục hồi kèm sau phẫu thuật với bệnh nhân bị bệnh võng mạc đái tháo đường ${ }^{8}$. Bên cạnh việc sử dụng dâuu silicon cho những trường hợp bong võng mạc phức tạp, thị lực kém trước mổ thì dâuu silicon còn liên quan đến sự mỏng đi của các lớp võng mạc vùng hoàng điểm trên $\mathrm{OCT}^{9}$.

\section{KẾT LUẬN}

Phẫu thuật cắt dịch kính có sử dụng dung dịch PFCL điều trị BVMco kéo do bệnh võng mạc ĐTĐ là kỹ thuật rất phức tạp, nhằm phục hồi giải phẫu và một phần thị lực cho bệnh nhân. Mặc dù thị lực cải thiện không cao vì nằm trong bệnh cảnh nặng nề chungcủa bệnh võng mạc ĐTÐ giai đoạn muộn. Với kỹ thuật và trang thiết bị được cải thiện, khả năng phục hồi về chức năng và giải phẫu đã có nhiêu hứa hẹn. Tuy nhiên, vẫn cần phải nhắc lại là việc sàng lọc và phát hiện sớm bệnh võng mac ĐTĐ có ý nghĩa rất lớn trong cộng đồng, mà kết quả là giảm thiểu số ca mắc bệnh giai đoạn muộn.

\section{TÀI LIÊU THAM KHẢO}

1. Haidt SJ, Clark LC, Ginsberg J. Liquid perfluorocarbon replacement in the eye.Invest Ophthalmol Vis Sci,.Published online 1982:22.

2. Chang $S$, Ozmert E, Zimmerman NJ. Intraoperative perfluorocarbon liquids in the management of proliferative vitreoretinopathy.Am J Ophthalmol. 1988;106(6):668-674. doi: 10.1016/ 0002-9394 (88)90698-8

3. Arevalo JF, Serrano MA, Arias JD. Perfluorocarbon in vitreoretinal surgery and preoperative bevacizumab in diabetic tractional retinal detachment. World J Diabetes. 2014;5(5): 724-729. doi:10.4239/wjd.v5.i5.724

4. Imamura $\mathbf{Y}$. Use of perfluorocarbon liquid during vitrectomy for severe proliferative diabetic retinopathy. British Journal of Ophthalmology. 2003;87(5):563-566. doi:10.1136/bjo.87.5.563

5. Sato T, Tsuboi K, Nakashima H, Emi K. Characteristics of cases with postoperative vitreous hemorrhage after 25-gauge vitrectomy for repair of proliferative diabetic retinopathy. Graefes Arch Clin Exp Ophthalmol. 2017;255(4):665-671. doi:10.1007/s00417-016-3522-8

6. Yang C-M, Yeh P-T, Yang C-H. Intravitreal longacting gas in the prevention of early postoperative vitreous hemorrhage in diabetic vitrectomy. Ophthalmology. 2007;114(4):710-715. doi: 10.1016/ j.ophtha.2006.07.047

7. Meleth AD, Carvounis PE. Outcomes of vitrectomy for tractional retinal detachment in diabetic retinopathy.Int Ophthalmol Clin. 2014;54(2):127-139.

doi:10.1097/IIO.0000000000000021

8. Yorston D, Wickham $L$, Benson S, Bunce $C$, Sheard R, Charteris D. Predictive clinical features and outcomes of vitrectomy for proliferative diabetic retinopathy. $\mathrm{Br} \mathrm{J}$ Ophthalmol. 2008;92(3):365-368. doi:10.1136/bjo.2007.124495

9. Christensen UC, la Cour M. Visual loss after use of intraocular silicone oil associated with thinning of inner retinal layers. Acta Ophthalmol. 2012; 90(8): 733-737. doi:10.1111/ j.1755-3768. 2011.02248.x 


\section{KẾT QUẢ ĐIỀU TRI PHẪU THUÂTT CỦA GLÔCÔM GÓC ĐÓNG NGUYÊN PHÁT}

\section{TÓM TẮT.}

Mục tiêu: Đánh giá đă̆c điểm lâm sàng, cận lâm sàng, kết quả điều trị phẫu thuật Glôcôm góc đóng nguyên phát. Đối tượng và phương pháp nghiên cứu: Mô tả, tiến cứu, có can thiêp lâm sàng không nhóm chứng, tiến hành trên 41 mắt Glôcôm góc đóng nguyên phát được phẫu thuật cắt bè củng giác mac hoặc laser cắt mống mắt chu biên tại Bệnh viện Mắt Nghệ An từ tháng 1/2021 đến tháng 4/2021. Kết quả: Bệnh nhân trên 60 tuổi $(73,4 \%)$, bệnh nhân nữ chiếm $66,7 \%$. Triệu chứng cơ năng chủ yếu: nhìn mờ (90\%) và đau nhức $(93,3 \%)$. Triệu chứng thực thể chủ yếu là tiền phòng nông $(100 \%)$, nhãn áp trung bình trước mổ là $21 \pm 3,9 \mathrm{mmHg}$. Cận lâm sàng chụp OCT: mức độ lõm đĩa > 0,3 chiếm 83,8\%. Sau phẫu thuật 1 tháng: thị lực ổn định hoăc tăng ít, không có trường hợp nào giảm thị lực so với trước phấu thuật. Nhãn áp sau mổ còn $17,4 \pm 1,1 \mathrm{mmHg}$. Không ghi nhận các biến chứng trong và sau mổ. Điều trị phâuu thuật hạ nhãn áp là phương pháp điều trị hiêuu quả và an toàn. laser

Tư khóa: Glôcôm góc đóng nguyên phát, cắt bè,

\section{SUMMARY}

\section{SURGICAL RESULTS OF PRIMARY ANGLE - CLOSURE GLAUCOMA}

Objectives: To describe the clinical \& paraclinical features and surgical results of primary angle - closure glaucoma. Subjects and methods: Prospective corelation study. Trabeculectomy or laser peripheral irdectomy was performed on 41 eyes of primary angle - closure glaucoma at Eye Hospital of Nghe An province from January 2021 to April 2021. Results: patients who were over 60 years old made up $73.4 \%$, the majority of the subjects were female $66,7 \%$. The physical symptoms included blurred vision (90\%) and painful eyes (93.3\%). The functional symptoms are mainly shallow anterior chamber (100\%), the mean IOP: $21 \pm 3,9 \mathrm{mmHg}$. Optical Coherence Tomography: $C / D>0.3(83,8 \%)$. One month of post-operation: decreasing visual acuity (0\%), the visual acuitis were remainded or increased in all most of cases. The mean preoperative intraocular pressure (IOP) was $17,4 \pm 1,1 \mathrm{mmHg}$. No complication is on operation or postoperation. Trabeculectomy and Laser peripheral irdectomy were effective and safe to decrease IOP.

Key words: Primary angle closure Glaucoma, Trabeculectomy, Laser.

\footnotetext{
${ }^{1}$ Bệnh viện Mắt Nghệ An

${ }^{2}$ Trường đai hoc y khoa Vinh

Chịu trách nhiệm chính: Trần Tất Thắng

Email: Thangmatna@gmail.com

Ngày nhận bài: 10.8.2021

Ngày phản biên khoa hoc: 4.10.2021

Ngày duyệt bài: 15.10.2021
}

Trần Tất Thắng ${ }^{1}$, Trịnh Thị Hà ${ }^{2}$

\section{I. ĐĂT VẤN ĐỀ}

Glôcôm là căn bênh gây mù lòa đứng thứ 2 trên thế giới cũng như ở Việt Nam và đây là mối đe dọa nguy hiểm đối với sức khỏe cộng đồng [1],[2]. Theo Tổ chức $Y$ tế Thế giới đến năm 2020 có khoảng 80 triêu người mắc bênh Glôcôm, trong đó có 11,2 triệu người mù lòa do bệnh này [1]. Chẩn đoán sớm và điều trị kịp thời cho bênh nhân giúp giảm thiểu tỷ lệ mù lòa. Phương pháp điều trị Glôcôm góc đóng nguyên phát chủ yếu bằng phẫu thuật, có rất nhiều loại phẫu thuật điều trị Glôcôm tuy nhiên hiện nay cắt bè củng giác mac và cắt mống mắt chu biên là được sử dung rộng rãi nhất, đặc biệt là laser cắt mống mắt chu biên ngày càng được ưu tiên lựa chọn và tính hiệu quả . Nghiên cứu thực hiện tại Bênh viện Mắt Nghệ An phẫu thuật Glôcôm góc đớng nguyên phát với mục tiêu Mô tả đăc điểm lâm sàng, cận lâm sàng và đánh giá kết quả điều trị Glôcôm góc đóng nguyên phát bằng phẫu thuật.

\section{II. ĐỐI TƯƠNG VÀ PHƯƠNG PHÁP NGHIÊN CỨU}

2.1. Đối tượng nghiên cứu. 30 bệnh nhân với 41 mắt Glôcôm góc đóng nguyên phát điều trị phẫu thuật tại Bệnh viện Mắt Nghệ An tù̀ tháng 1/2021- 4/2021 đủ tiêu chuẩn tham gia nghiên cứu.

2.2. Phương pháp nghiên cứu. Phương pháp mô tả, tiến cứu tất cả các trường hợp Glôcôm góc đóng nguyên phát được điều trị bằng phẩu thuật.

\section{Tiến hành khám bệnh:}

- Đo thị lực bằng bảng Landolt

- Đo nhãn áp bằng nhãn áp Maclakov

- Khám bằng kính sinh hiển vi: Đánh giá độ sâu góc tiền phòng, đánh giá độ mở góc tiền phòng theo phân loại Shaffer.

\section{Làm các cận lâm sàng:}

- Chụp cắt lớp võng mạc OCT: Đánh giá tỷ lệ Iõm/ đĩa, độ dày lớp sợi thần kinh quanh gai

- Làm các xét nghiêm cơ bản trước phẫu thuật.

Phương pháp phẫu thuật: Cắt bè củng giác mạc hoặc laser mống mắt chu biên dựa vào kết quả của khám lâm sàng và cận lâm sàng.

Theo dõi bệnh nhân trong phẫu thuật, thời gian hậu phẫu sau 1 ngày, 1 tuần và 1 tháng.

\subsection{Biến số nghiên cứu}

- Thông tin chung về đối tượng nghiên cứu 
- Đặc điểm lâm sàng của bệnh Glôcôm góc đóng nguyên phát

- Đánh giá kết quả phẫu thuật

2.4 Xử lí số liệu Bằng SPSS 20.0

\section{KẾT QUẢ NGHIÊN CỨU}

3.1. Đặc điểm chung của đối tượng nghiên cứu trước phẫu thuật

Bảng 1. Đặc điểm chung bệnh nhân

\begin{tabular}{|c|c|c|c|}
\hline \multicolumn{2}{|c|}{ Đặc điếm } & n & $\mathbf{( \% )}$ \\
\hline \multirow{4}{*}{ Nhóm tuổi } & $<40$ & 1 & 3.3 \\
\cline { 2 - 4 } & $40-49$ & 3 & 10 \\
\cline { 2 - 4 } & $50-59$ & 4 & 13,3 \\
\cline { 2 - 4 } & $60-69$ & 11 & 36,7 \\
\cline { 2 - 4 } & $>70$ & 11 & 36,7 \\
\hline \multirow{2}{*}{ Giới } & Nam & 10 & 33,3 \\
\cline { 2 - 4 } & Nữ & 20 & 66,7 \\
\hline
\end{tabular}

Glôcôm góc đóng nguyên phát hay gặp nhất ở nhóm tuổi già trên 60 tuổi, chiếm tî lệ là $73,4 \%$, độ tuổi trung bình là $64,2 \pm 10,7$ tuổi, nhỏ nhất là 39 tuổi lớn tuổi nhất là 81 tuổi.

Tỷ lệ nữ $/$ nam $=2 / 1$, trong đó nữ chiếm $66,7 \%$, nam chiếm $33,3 \%$.

3.2. Triệu chứng lâm sàng, cận lâm sàng

- Triệu chứng cơ năng:

Bảng 2. Đánh giá triệu chứng cơ năng

\begin{tabular}{|c|c|c|}
\hline Triệu chứng & $\mathbf{n}$ & $\mathbf{( \% )}$ \\
\hline Đau nhức mằt & 28 & $93,3 \%$ \\
\hline $\begin{array}{c}\text { Nhìn mờ, nhìn đèn có } \\
\text { quầng xanh đỏ }\end{array}$ & 27 & $90 \%$ \\
\hline Nhức đâu, buồn nôn & 4 & $13,3 \%$ \\
\hline Sợ ánh sáng & 2 & $6,7 \%$ \\
\hline
\end{tabular}

Đa số bệnh nhân có triệu chứng cơ năng như đau nhức 93,3\% và triệu chứng nhìn mờ hoặc nhìn có quầng xanh đỏ $90 \%$. Số bênh nhân có triệu chứng nhức đầu, buồn nôn chiểm $13,3 \%$ và bệnh nhân có triêuu chứng sợ ánh sáng chiếm 6,7\%.

- Triệu chứng thức thể

Khám trên kính sinh hiển vi

Bảng 3. Triêuu chứng quan sát trên kính SHV

\begin{tabular}{|c|c|c|}
\hline Triêu chứng & $\mathbf{n}$ & (\%) \\
\hline Cương tụ rìa & 11 & $26,8 \%$ \\
\hline Giác mạc phù & 7 & $17,1 \%$ \\
\hline Tiền phòng nông & 41 & $100 \%$ \\
\hline Đồng tử giãn, phản xạ & 15 & $36,6 \%$ \\
\hline $\begin{array}{l}\text { Khi khám bằng kính } \\
\text { Glôcôm góc đóng nguyê } \\
\text { tiền phòng nông, 26,8\% } \\
17,1 \% \text { mắt có giác mạc } \\
\text { tứ giãn hoăc phản xa lười } \\
\text { Thi lực trước phẫu } \\
\text { Bảng 4. Bảng đán } \\
\text { phâ̂u thuât }\end{array}$ & trên & $\begin{array}{l}1 \text { mắt b } \\
\text { \% mắt có } \\
\text { ng tụ rìa, } \\
\text { t có đồng }\end{array}$ \\
\hline Thị lức chỉnh kính & $\mathbf{n}$ & (\%) \\
\hline$\leq$ ĐNT $3 \mathrm{~m}$ & 6 & 14,6 \\
\hline
\end{tabular}

\begin{tabular}{|c|c|c|}
\hline$>$ ĐNT 3m $-1 / 10$ & 9 & 22 \\
\hline$>1 / 10-3 / 10$ & 13 & 31,7 \\
\hline$>3 / 10-7 / 10$ & 10 & 24,4 \\
\hline$>7 / 10$ & 3 & 7,3 \\
\hline Tống & $\mathbf{4 1}$ & $\mathbf{1 0 0} \%$ \\
\hline
\end{tabular}

Trong nghiên cứu của chúng tôi, phần lớn bệnh nhân vào viện với thị lực dưới $3 / 10$ chiếm $68,3 \%$.

Nhãn áp trước phẫu thuật

Bảng 5. Bảng đánh giá nhãn áp trước phẫu thuật

\begin{tabular}{|c|c|c|}
\hline Mức NA (mmHg) & $\mathbf{n}$ & $\mathbf{( \% )}$ \\
\hline$\leq 23$ & 30 & 73,2 \\
\hline $24-32$ & 11 & $26,8 \%$ \\
\hline$>32$ & 0 & $0 \%$ \\
\hline Tống & $\mathbf{4 1}$ & $\mathbf{1 0 0} \%$ \\
\hline
\end{tabular}

Nhãn áp của bệnh nhân khi vào viện chủ yếu $<24 \mathrm{mmHg}$ chiếm $73,2 \%$, nhãn áp trung bình 21 $\pm 3,9 \mathrm{mmHg}$.

- Cận lâm sàng

Bảng 6. Tỷ lệ C/D trước phẫu thuật \begin{tabular}{|l|l|l}
\hline Tỷ lệ lõm/đĩa (C/D) & $\mathbf{n}$ & $\mathbf{( \% )}$ \\
\hline
\end{tabular}

\begin{tabular}{|c|c|c|}
\hline$\leq 0,3$ & 6 & 16,2 \\
\hline $0,4-0,6$ & 16 & 43,2 \\
\hline$\geq 0,7$ & 15 & 40,6 \\
\hline Tống & $\mathbf{3 7}$ & $\mathbf{1 0 0}$ \\
\hline
\end{tabular}

Trong 37 mắt được chụp OCT mức độ lõm đĩa $>0,3$ chiếm $83,8 \%$, trong đó lõm đĩa rộng $\geq 0,7$ chiếm tới 40,6\%.

3.3. Kết quả sau phẫu thuật

- Thi lức sau phấu thuât

Bảng 7. Sư thay đổi thị lực sau phẫu thuật 1 tháng so với trước mố

\begin{tabular}{|c|c|c|c|c|}
\hline \multirow{2}{*}{$\begin{array}{l}\text { Thay } \\
\text { đổi thị } \\
\text { lực }\end{array}$} & \multicolumn{2}{|c|}{$\begin{array}{l}\text { Cắt bè củng } \\
\text { giác mạc }\end{array}$} & \multicolumn{2}{|c|}{$\begin{array}{c}\text { Cắt mống măt } \\
\text { chu biên }\end{array}$} \\
\hline & $\begin{array}{c}\text { Số } \\
\text { mắt }\end{array}$ & $\begin{array}{l}\text { Tỷ lệ } \\
\%\end{array}$ & $\begin{array}{c}\text { Số } \\
\text { mắt }\end{array}$ & $\begin{array}{c}\text { Tỷ lệ } \\
\text { \% }\end{array}$ \\
\hline Giảm & 0 & $0 \%$ & 0 & $0 \%$ \\
\hline Ön định & 13 & $81,2 \%$ & 20 & $80 \%$ \\
\hline Tăng & 3 & $18,8 \%$ & 5 & $20 \%$ \\
\hline Tống & 16 & $100 \%$ & 25 & $100 \%$ \\
\hline
\end{tabular}

Trong nghiên cứu của chúng tôi, sau 1 tháng không có mắt nào giảm thị lực, mắt có thị lực trên $3 / 10$ chiếm $36,6 \%$, tăng so với trước mổ (31,7\%) nhưng không đáng kể. Trong đó, 16 mắt được cắt bè củng giác mạc thì thị lực tăng chiếm $18,8 \%$, ổn định chiếm tî lệ là $81,2 \%$, tương tự trong 25 mắt laser mống mắt chu biên thị lực tằng là $20 \%$, ổn định cũng chiếm $80 \%$.

- Điều chỉnh nhãn áp sau phẫu thuật

Bảng 8. Điều chỉnh nhãn áp sau phẫu thuật sau 1 tháng

\begin{tabular}{|c|c|c|c|c|}
\hline \multirow{2}{*}{$\begin{array}{c}\text { Mức NA } \\
\text { (mmHg) }\end{array}$} & \multicolumn{2}{|c|}{$\begin{array}{c}\text { Cắt bè củng } \\
\text { giác mạc }\end{array}$} & \multicolumn{2}{|c|}{$\begin{array}{c}\text { Cắt mốt mống } \\
\text { mắt chu biên }\end{array}$} \\
\cline { 2 - 5 } & Số & Tỷ & Số & Tỷ lệ \\
\hline
\end{tabular}




\begin{tabular}{|c|c|c|c|c|}
\hline & mắt & lệ\% $\%$ & mắt & $\mathbf{\%}$ \\
\hline$\leq 23$ & 16 & $100 \%$ & 25 & $100 \%$ \\
\hline $24-32$ & 0 & $0 \%$ & 0 & $0 \%$ \\
\hline$>32$ & 0 & $0 \%$ & 0 & $0 \%$ \\
\hline Tổng & 16 & $100 \%$ & 25 & $100 \%$ \\
\hline
\end{tabular}

Sau phẫu thuật $100 \%$ mắt đều có nhãn áp điều chỉnh dưới $24 \mathrm{mmHg}$, nhãn áp trung bình là $17,4 \pm 1,1 \mathrm{mmHg}$.

Đối với 16 mắt phẫu thuật cắt bè cùng giác mạc thì nhãn áp trung bình sau mổ 1 tháng là $17,9 \pm 1,3 \mathrm{mmHg}$. Đối với 25 mắt laser mống mắt chu biên thì nhãn áp trung bình sau mổ 1 tháng là $17,2 \pm 1 \mathrm{mmHg}$

- Biến chứng sau theo dõi 1 tháng. Trong nghiên cứu của chúng tôi trên 16 mắt cắt bè củng giác mạc và 25 mắt cắt mống mắt chu biên thì trên cả 41 mắt đều chưa ghi nhận các biến chứng tại các thời điểm theo dõi.

\section{BÀN LUÂNN}

4.1. Đặc điểm chung. Trong nghiên cứu của chúng tôi từ bảng 1 thấy rằng, Glôcôm góc đóng nguyên phát hay gặp nhất ở nhóm tuổi trên 60 chiếm 73,4\%, tuổi trung bình $64,2 \pm 10,7$ tuổi. So sánh với nghiên cứu khác như Phạm Thi Thu Hà (2018) là 59,4 $\pm 12,5$ tuổi [3], Zhonghua Yan Ke Za Zhi (2019) là $59 \pm 7$ tuối [4] cho thấy kết quả tương đồng.

Cũng từ bảng 1 ta thấy nữ mắc nhiều hơn nam, tỷ lệ nữ/ nam=2/1. Kết quả phù hợp với nghiên cứu dịch tễ học thì nữ giới gặp nhiều hơn nam giới. Chúng tôi nhận thấy kết quả tương đồng khi so sánh với tác giả Lương Thị Hải Hà, Đặng Đức Minh (2019) khi nữ giới chiếm 67,3\% [5].

4.2. Đặc điểm lâm sàng, cận lâm sàng

4.2.1. Triệu chứng cơ năng. Từ kết quả bảng 2 cho thây triệu chứng hay gặp nhất đau nhức $93,3 \%$ và nhìn mờ hoặc nhìn có quâng xanh đỏ $90 \%$. Các triệu chứng khác chiếm tỷ lệ thấp lần lượt là nhức đầu, buồn nôn chiếm 13,3\%, sợ ánh sáng chiếm $6,7 \%$. Như vậy, đau nhức và nhìn mờ là hai triệu chứng cớ năng chính. Triệu chứng thường tiến triển chậm, mãn tính, nên bệnh nhân thường khó phát hiện, bệnh nhân chỉ đỉ khám khi thị lực đã giảm sút rất nhiều. Vì vậy công tác chẩn đoán và điều trị còn gặp rất nhiều khó khăn.

\subsubsection{Triêu chứng thức thể}

Khám trên kính sinh hiển vi. Từ bảng 3 chúng tôi nhân thấy tất cả bênh nhân đều có tiền phòng nồng (100\%). Như vậy, tiền phòng nông là triệu chứng chính có thể khám thây được trên kính sinh hiển vi. Điều này là phù hợp vì mắt có tiền phòng nông là một trong những yếu tố nguy cơ của Glôcôm góc đóng nguyên phát.

Thị lực trước phẫu thuật. Từ bảng 4 cho thây trong nghiên cứu của chúng tôi, phần lớn bệnh nhân vào viện với thị lực dưới $3 / 10$ chiếm $68,3 \%$. Điều này có thể giải thích do bệnh nhân không có các triệu chứng rõ ràng, tiến triển chậm nên bệnh nhân thường đến khám khi thị lực đã giảm sút nhiều.

Nhãn áp trước phẫu thuật. Từ bảng 5 cho thây nhãn áp của bệnh nhân khi vào viện chủ yếu $<24 \mathrm{mmHg}$ chiếm 73,2\%, nhãn áp trung bình 21 $\pm 3,9 \mathrm{mmHg}$. So sánh với những nghiên cứu tương tự khác trong nước, theo Phạm Tân Tiến (2008) [6], nhãn áp trung bình khi bệnh nhân nhập viện là $17,65 \pm 1,75 \mathrm{mmHg}$, nhãn áp trung bình của chúng tôi cao hơn vì tiêu chuẩn chọn bệnh nhân của tác giả là chỉ nghiên cứu trên bệnh nhân Glôcôm giai đoan tiềm tàng và sơ phát.

4.2.3. Cận lâm sàng. Từ bảng 5 chúng tôi nhận thấy, trong 37 mắt được chụp OCT mức độ Iõm đĩa > 0,3 chiếm $83,8 \%$, trong đó lõm đĩa rộng $\geq 0,7$ chiếm tới $40,6 \%$. Việc đánh giá tình trạng lõm đĩa đóng vai trò quan trọng trong việc chẩn đoán và và theo dõi tiến triển bệnh Glôcôm.

\subsection{Kết quả phẫu thuâtt}

4.3.1. Thị lực sau phẩu thuât. Từ kết quả bảng 6 cho thấy trong nghiên cứu của chúng tôi, sau 1 tháng không có mắt nào giảm thị lực, mắt có thị lực trên $3 / 10$ chiếm $36,6 \%$, tăng so với trước mổ $(31,7 \%)$ nhưng không đáng kể. Trong đó, 16 mắt được cắt bè củng giác mạc thì thị lực tăng chiếm $18,8 \%$, ổn định chiếm tỉ lệ là $81,2 \%$, tương tự trong 25 mắt laser mống mắt chu biên thị lực tăng là $20 \%$, ổn định cũng chiếm $80 \%$. Như vậy, sau khi phẩu thuật thì thị lực của bệnh nhân hầu như chỉ tăng rất ít, chủ yếu là ổn định.

4.3.2. Điều chỉnh nhãn áp sau phẫu thuật. Từ kết quả bảng 7 cho thấy sau phẫu thuật $100 \%$ mắt đều có nhãn áp điều chỉnh dưới $24 \mathrm{mmHg}$, nhãn áp trung bình là $17,4 \pm 1,1 \mathrm{mmHg}$.

Đối với 16 mắt phẫu thuật cắt bè cùng giác mạc thì nhãn áp trung bình sau mổ 1 tháng là $17,9 \pm 1,3 \mathrm{mmHg}$, theo 1 số nghiên cứu gần đây như của Nguyễn Hồ Việt Liên, Phan Văn Năm (2014) [7] nhãn áp trung bình khi ra viện 1 tháng là $16,41 \pm 3,49 \mathrm{mmHg}$ ta thấy có sự khác biệt so với nghiên cứu của chúng tôi. Có sự khác nhau như vậy do nghiên cứu của chúng tổi tỷ lệ Glôcôm góc đóng mạn tính chiếm tỷ lệ cao $(61 \%)$ trong khi nghiên cứu của tác giả Nguyễn Hồ Viêt Liên chỉ là $25 \%$.

Đối với 25 mắt laser mống mắt chu biên thì nhãn áp trung bình sau mổ 1 tháng là 17,2 \pm 
$1 \mathrm{mmHg}$. So sánh với tác giả khác như ta thấy kết quả tương đồng như Phạm Tân Tiến (2008) [6] nhãn áp trung bình sau mổ 1 tháng là 17,45 $\pm 1,49 \mathrm{mmHg}$.

4.3.3. Biến chứng sau phẫu thuật. Trong nghiên cứu của chúng tôi trên 16 mắt cắt bè củng giác mạc và 25 mắt cắt mống mắt chu biên thì trên cả 41 mắt đều chưa ghi nhận các biến chứng tại các thời điểm theo dõi.

Trong phẫu thuật cắt bè củng giác mạc, theo nghiên cứu của Nguyễn Hồ Việt Liên, Phan Văn Năm (2014) [7] thì tỷ lệ gặp biến chứng sau phẫu thuật như viêm màng bồ đào chiếm $12,5 \%$ và đục thể thửy tinh là 6,3\% sau 3 tháng theo dõi.

Trong phẫu thuật laser mống mắt chu biên theo tác giả Vũ Thị Thái, Nguyễn Thị Hà Thanh (2018) [8], nghiên cứu trên 141 mắt trong 2 năm thì cũng không có trường hợp nào bị bít hay không rõ lỗ cắt, ngoài ra cũng không gặp các biến chứng khác.

Có sự khác biệt giữa nghiên cứu của chúng tôi so với các tác giả khác là do số bệnh nhân nghiên cứu của chúng tôi là ít hơn rất nhiêu so với các nghiên cứu khác đồng thời thời gian theo dõi rất ngắn (1 tháng) nên không thể theo dõi được các biến chứng muộn sau phẫu thuật như viêm màng bồ đào hay đục thể thủy tinh.

\section{KẾT LUẦN}

1. Đặc điểm lâm sàng, cận lâm sàng

- Bệnh nhân chủ yếu trền 60 tuổi chiếm $73,4 \%$, tuổi trung bình $64,2 \pm 10,7$ tuổi. Nữ gấp đôi nam.

- Triệu chứng lâm sàng thường gặp: nhìn mờ (90\%) và đau nhức $(93,3 \%)$, tiền phòng nông
(100\%) , thị lực giảm, nhãn áp tăng

- Triệu chứng cận lâm sàng trên OCT: chủ yếu mức lõm đĩa $>0,3(83,8 \%)$.

\section{Kết quả điêu trị}

- Thị lực tăng ít hoặc ổn định

- Sau phẫu thuật nhãn áp trung bình còn

$17,4 \pm 1,1 \mathrm{mmHg}$.

- Không có biến chứng sau phẫu thuật.

\section{TÀl LIẸU THAM KHẢO}

1. Giangiacomo A, Coleman AL (2009). The epidemiology of Glaucoma.Glaucoma, Spinger, Hardcover, pp22-26.

2. Đố Như Hơn (2011). Đại cương Glôcôm, Nhãn khoa, Nhà xuất bản Y học, pp 224-235.

3. Pham Thi Thu Hà (2018). Nghiên cứu đăc điềm lâm sàng và kết quả điều trị Glôcôm ác tính, Luận văn tiến sĩ y học, Trường đai hoc Y Hà Nội.

4. Zhonghua Yan Ke Za Zhi (2019). Preliminary efficacy of penetrating canaloplasty in primary angle- closure Glaucoma. The eyes hospital of Wenzhou Medical.

5. Lương Thi Hải Hà, Đăng Đức Minh (2019). Đăc điểm rối loạn sắc giác trên bệnh nhân Glôcôm nguyên phát. Tap chí Y dược lâm sàng 108, trường đại học y dược Thái Nguyên.

6. Phạm Tân Tiến (2008). Nghiên cứu ứng dụng laser Nd:YAG với hai bước sóng khác nhau cắt mống mắt chu biên điêu trị Glôcôm góc đóng, Luận văn tiến sỹ y học, Học viện Quân y.

7. Nguyến Hồ Việt Liên, Phan Văn Năm (2014). Nghiên cứu đăc điểm lâm sàng và kết guả điều trị Glôcôm góc đóng nguyên phát bằng phâuu thuật tai Khoa Mắt Bệnh viện Trung ương Huê. luận văn bác sĩ nôi trú, trường Đ̇ai hoc $Y$ dước Huế

8. Vũ Thị Thái, Nguyến Thị Hà Thanh (2018). Đánh giá kết quả lâu dài của phẫu thuật cắt mống mắt chu biên điêu trị Glôcôm nguyên phát tại khoa Glôcôm bệnh viện Mắt Trung ương, luận vằn tiến sĩ, trường Đại học y Hà Nội.

\section{ĐÁNH GIÁ KẾT QUẢ THẨM MỸ 5 NĂM XA TRI ĐIỀU BIẾN LIỀU SAU PHẪU THUÂTT UNG THƯ VÚ BẢO TỒN GIAI ĐOẠN I-II TẠI BÊ̂NH VIỆN K}

\section{TÓM TẮT}

Ung thư vú là bênh ung thư thường găp nhất ở phụ nữ. Điều trị bảo tồn chỉ định cho giai đoạn I-II, xạ trị bổ trợ sau phẫu thuật bảo tồn là chỉ định bắt buộc.

*Bệnh viện $K$

Chịu trách nhiệm chính: Nguyễn Công Hoàng

Email: hoangdoc@gmail.com

Ngày nhận bài: 9.8.2021

Ngày phản biên khoa hoc: 4.10 .2021

Ngày duyệt bài: 14.10 .2021

\section{Nguyễn Công Hoàng ${ }^{1}$, Đinh Công Định ${ }^{2}$}

Xạ trị điều biến liều (F-IMRT) là kỹ thuật sử dụng máy gia tốc có trang bi hê thống collimator đa lá có khả năng tối ưu hóa kế hoạch xạ trị, cải thiện rõ rệt phân bố liều tai thể tích điều trị, giảm liều xa vào tổ chức lành xung quanh. Nghiên cứu nhằm nhẩn xét một số đăc điểm lâm sàng và đánh giá kết quá̉ thẩm mỹ̃ tai thời điểm 5 năm sau xạ trị điêu biến liều ung thư vú bảo tồn tại bệnh viện $K$. Đối tượng và phương pháp nghiên cứu: 68 bệnh nhân đủ tiêu chuẩn cụ thể giai đoạn I, II điều trị bảo tồn tại Bệnh viện $\mathrm{K}$ từ tháng 02/2016 đến 10/2021. Xa trị kỹ thuật điểu biến liều (F-IMRT). Nghiên cứu mô tả, tiến hành thu thập 
thông tin về lâm sàng, đánh giá kết quả điều trị sau 5 năm, kết quả thẩm mỹ theo thang điểm Lowery Carlson. Kết quả: Trung vị tuổi BN là 44, trẻ nhất 21, vị trí u $1 / 4$ trên ngoài thường gặp nhất $(64,2 \%)$, giai đoạn I -IIA 91,2\% là chủ yếu. Thể tích vú trung bình và nhỏ chiếm đa số $90,3 \%$. Thời gian sống thêm không bệnh 5 năm là 92,6\%, sống thêm toàn bộ 5 năm là $95,6 \%$. Kết quả thẩm mỹ mức đạt chiếm 80,2\%. Kết luận: Trong nghiên cứu tuổi trung bình khá trẻ, hiệu quả điều trị bệnh tốt, kết quả thẩm mỹ mức đạt khá cao. Tuy nhiên các biến chứng của xạ trị ảnh hưởng đến kết quả thẩm mỹ thường muộn sau khi điều trị nhiều năm, vây cần có theo dõi dài hơn sau điều trị để có những kết luận chính xác hơn.

\section{SUMMARY}

\section{YEARS COSMETIC OUTCOME AFTER} INTENSITY MODULATED RADIATION THERAPY FOLLOWED CONSERVATIVE SURGERY OF BREAST CANCER STAGE I-II AT K HOSPITAL

Breast cancer is the most common cancer in women. While conservative treatment is indicated for early stage breast cancer (stage I-II), adjuvant radiation therapy is mandatory. Forward intensity modulated radiotherapy (F-IMRT) is a modern radiation technique by using LINAC with multileaf collimator system to optimize radiation treatment plan in order to improve homogeneity of PTV, minimizing the dose to organ at risks. Our study aims to review clinical features and 5 years cosmetic outcome after FIMRT followed breast cancer conservative treatment of at $K$ hospital. Objectives and methods: 68 eligible patients with stage I-II breast cancer were selected, treated by forward IMRT followed conservative surgery from 2/2016 to 10/2021 at K Hospital. Review clinical features and estimate cosmetic outcome at the end of 5 years postoperative radiotherapy. Result: Clinical features of 68 eligible patients: median age is 44; the lowest is 21; tumor location: left breast accounted for $61.2 \%$, upper outer quadrant of the breast is most common (64.2\%). TNM stage: mostly stage I-IIA (91.2\%); Breat volume: most patients with small and average breast volume (90.3\%). The 5-year disease-free survival (DFS) rates are $92.6 \%$. The 5years overall survival (OS) rates is $95.6 \%$. Quality of cosmetic outcome account for $80.2 \%$ (Excellent: $37.6 \%$; Good: $20.8 \%$; Fair: $21.8 \%$ ). Conclusion: In our study, the 5-year disease-free survival was $92.6 \%$, the 5 -year overall survival was $95.6 \%$. we found that high rate of fair, good and excellent cosmetic result group reached $80.2 \%$. The side effects of radiation therapy that affect cosmetic results often occur late, so long-term follow-up after treatment is required for more accurate conclusions.

\section{I. ĐĂT VẤN ĐỀ}

Ung thư vú là bênh hay găp nhất ở phụ nữ và là nguyên nhân gây tử vong thứ hai sau ung thư phổi tại các nước trên thế giới. Theo Globocan 2018, tại Việt Nam hàng năm có khoảng 15229 ca mới mắc, số tử vong là hơn 6000 bệnh nhân. Theo nghiên cứu gánh nặng bệnh ung thư và chiến lược phòng chống ung thư quốc gia đến năm 2020 thì UTV là bệnh có tỷ lệ mới mắc cao nhất trong các ung thư ở nữ giới [1].

Nguyên tắc chung của điều trị ung thư vú là điều trị phối hợp các phương pháp phẫu thuật, xạ trị và điều trị toàn thân. Kỹ thuật xạ 3D vẫn là phổ biến nhất, tỷ lệ tái phát tại chỗ sau 05 năm từ $4,5 \%-12 \%$. Tuy nhiên các tác dụng phu muộn như xơ hóa diên chiếu xạ, phù bạch huyết tay, teo tuyến vú... vẫn thường hay gặp gây biến dang, thay đổi sắc tố da, mô vú teo nhỏ mất cân đối, mật độ cứng, ảnh hưởng nhiều đến thẩm mỹ [2], [3]. Xa trị điều biến liều (F-IMRT) là kỹ thuật sử dụng máy gia tốc có trang bị hệ thống collimator đa lá, các trường chiếu nhỏ được tạo ra nhằm tối ưu hóa kế hoạch xạ trị, cải thiện về phân bố liều xạ, tăng khả năng tập trung liểu tại thể tích điều trị, hạn chế liều tới tổ chức lành xung quanh. Kết quả điều trị bệnh và thẩm mỹ cải thiện có ý nghĩa thống kề, biến chứng da bị xơ chai cứng, mô vú teo nhỏ với thể tích vú còn $<50 \%$ không gặp ở nhóm điều trị F-IMRT [3]. Bênh viện $\mathrm{K}$ áp dụng kỹ thuật xạ trị này trong điều trị UTV bảo tồn hơn 5 năm, chúng tôi tiến hành đề tài với muc tiêu:

Một số đặc điểm lâm sàng nhóm nghiên cứu

Đánh giá kết quả thẩm mỹ 5 năm sau xạ trị điều biến liều ung thư vú bảo tồn

\section{II. ĐỐI TƯỢNG VÀ PHƯƠNG PHÁP NGHIÊN CỨU}

Đối tượng nghiên cứu. 68 bệnh nhân đủ tiêu chuẩn được lựa chọn vào nghiên cứu với các tiêu chí cư thể: ung thư vú nữ, một bên được điều trị bảo tồn, giai đoạn sớm (T1-2 N0-1 MO) theo AJCC 2010, tuân thủ đầy đủ phác đồ, có chì số toàn trạng (PS) 0-1. Không lựa chọn BN có tiền sử ung thư khác, đã xạ vào vùng ngực, vú. Thời gian từ tháng 02/2016 đến 10/2021, tại Bệnh viện K.

Phương pháp nghiên cứu mô tả chùm ca bệnh

Các bước tiến hành: Thu thập thông tin về đặc điểm bệnh nhân, phương pháp điều trị.

Xa trị: Phương tiện máy CT mô phỏng, máy gia tốc với collimator đa lá mức năng lượng 6 MV, dụng cụ cố định, kỹ thuật xạ trị điều biến liều (F-IMRT) liều toàn vú 50Gy, liều tăng cường tại vị trí u 14-16Gy.

Mô phỏng điều trị, lâp kế hoạch điều trị theo ICRU 50 và 62 , đánh giá chất lượng trước xạ trị, tiến hành xạ trị và đánh giá kết quả.

Tiêu chuẩn đánh giá: Phân loại giai đoạn theo AJCC - 2010, đánh giá kết quả điều trị, đánh giá thẩm mỹ theo thang điểm Lowery Carlson. 


\section{KẾT QUẢ NGHIÊN CỨU VÀ BÀN LUẬN Bảng 1. Môt số đặc điểm lâm sàng}

\begin{tabular}{|c|c|c|c|}
\hline Đặc điểm & 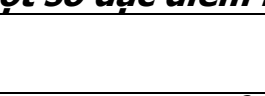 & n: 68 & $\begin{array}{l}\text { Tỷ lệ } \\
(\%)\end{array}$ \\
\hline \multirow{3}{*}{$\begin{array}{l}\text { Thể tích vú } \\
\text { (V) }\end{array}$} & V-To: $>975 \mathrm{~cm}^{3}$ & 10 & 9,7 \\
\hline & $\begin{array}{c}\text { V - TB: } 500- \\
975 \mathrm{~cm}^{3}\end{array}$ & 64 & 62,1 \\
\hline & $\begin{array}{c}\text { V - Nhỏ: } \leq 500 \\
\mathrm{~cm}^{3}\end{array}$ & 29 & 28,2 \\
\hline \multirow{3}{*}{$\begin{array}{l}\text { Giai đoạn } \\
\text { (TNM) }\end{array}$} & I & 42 & 61,8 \\
\hline & IIA & 20 & 29,4 \\
\hline & IIB & 6 & 8,8 \\
\hline \multirow{2}{*}{$\begin{array}{c}\text { Phẩu thuật } \\
\text { Bảo tồn vú + } \\
\text { tạo hình } \\
\end{array}$} & Có & 31 & 45,6 \\
\hline & Không & 37 & 54,4 \\
\hline \multirow{2}{*}{$\begin{array}{l}\text { Điều trị hóa } \\
\text { chất }\end{array}$} & Có & 39 & 57,4 \\
\hline & Không & 29 & 42,8 \\
\hline \multirow{2}{*}{$\begin{array}{c}\text { Điều trị nội } \\
\text { tiết }\end{array}$} & Có & 42 & 61,8 \\
\hline & Không & 26 & 38,2 \\
\hline \multirow{6}{*}{ Vị trí u } & Vú trái & 37 & 54,4 \\
\hline & Vú phải & 31 & 43,6 \\
\hline & 1/4 trên-ngoài & 38 & 55,9 \\
\hline & $1 / 4$ trên-trong & 9 & 13,2 \\
\hline & 1/4 dưới-ngoài & 14 & 20,6 \\
\hline & 1/4 dưới-trong & 7 & 10,3 \\
\hline
\end{tabular}

Trong nghiên cứu tuổi của bệnh nhân trung bình là 44, hay gặp nhất 40 đến 49 tuổi chiếm $38,8 \%$, trẻ hơn so với các nghiên cứu khác như tác giả Pham Hồng Khoa tuổi trung bình 50,5. U vú trái chiếm $54,4 \%$; $1 / 4$ trên ngoài hay gặp nhất (55,9\%). Theo Phạm Hồng Khoa (2016) thư vú trái là $56,8 \% ; 1 / 4$ trên ngoài là $64,2 \%$ [4]. Giai đoạn TNM phần lớn bệnh nhân là giai đoạn I IIA 91,2\%; giai đoạn IIB chỉ chiếm 8,8\%. Về thể tích vú: đa số bệnh nhân trong nhóm nghiên cứu có thể tích vú trung bình $\left(500-975 \mathrm{~cm}^{3}\right)$ chiếm $62,1 \%$; thể tích vú nhỏ $28,2 \%$, lớn chỉ chiếm $9,7 \%$. So với các tác giả ở phương Tây, Nhật Bản thấy rằng thể tích vú của phụ nữ tham gia nghiên cứu này nhỏ hơn, một nghiên cứu của

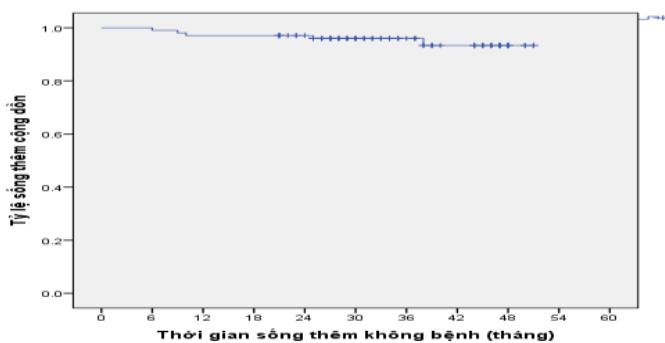

Biêu đồ 1. Thời gian sống thêm không bệnh, sông thêm toàn bộ

Thời gian sống thêm không bệnh (DFS) tại thời điểm 5 năm 92,6\%. Kết quả nghiên cứu này tương tự kết quả nghiên cứu của các tác giả
Philippe Piggnol (canada) cho thây kích thước vú $>975 \mathrm{~cm}^{3}$ chiếm 32,9\%, TB 50\%, kích thước nhỏ $<500 \mathrm{~cm}^{3}$ chỉ chiếm 17,1\%; tác giả Yuki Nohara (Japan) thì thấy răng kích thước vú $>975 \mathrm{~cm}^{3}$ chiếm $24,2 \%$, TB 58,6\%, kích thước nhỏ $<500$ $\mathrm{cm}^{3}$ chỉ chiếm $16,7 \%$ [5]. Về phương pháp điều trị thì có $57,4 \%$ bênh nhân được bổ trớ hóa chất trước khi xa trị và $42,8 \%$ được xa trị bổ trơ ngay sau phẫu thuật. Điều trị nội tiết có $61,8 \%$ bệnh nhân đó là những trường hợp $E R$ và/ hoặc $P R$ dương tính, tỷ lệ dương tính của thụ thể nội tiết cũng tương tự các nghiên cứu khác. Tác giả Ta Văn Tờ nghiên cứu trên 2207 bệnh nhân ung thư vú thây rẳng tỷ lệ $E R$ và/hoặc $P R$ dương tính là $63,3 \%$, trong đó $E R$ dương tính là $59,1 \%$, $P R$ dương tính là $51,4 \%$, tỷ lệ cả $E R$ và $P R$ dương tính là 47,2\% [6].

Thời gian sống thêm. Tính đến tháng 9 năm 2021, có 3 bênh nhân tử vong tai thời điểm 15 tháng và 48 tháng. Tỷ lê sống thềm toàn bộ (OS) 5 năm là $95,6 \%$. Trong số tử vong có bệnh nhân nữ 52 tuổi, ung thư vú giai đoạn T2NOMO, giải phẫu bệnh là ung thư thể tiểu thùy xâm nhâp, thu thể nôi tiết âm tính, Ki67 dương tính, HER 2 âm tính. Bệnh nhân được phẫu thuật bảo tồn kết hợp hóa chất bổ trợ phác đồ $4 A C-4 T$, tia xạ bổ trợ. Sau 25 tháng, xuất hiện tái phát di căn gan, bềnh nhân chuyển sang điều trị tai Hàn Quốc bệnh tiến triển và tử vong sau 48 tháng. Bệnh nhân khác nữ 45 tuổi, ung thư vú trái T2N1M0, ung thư thể ống xâm nhập độ III, thụ thể nội tiết âm tính Ki67 dương tính 100\%, HER 2 âm tính, sau phẩu thuật bảo tồn, chất bổ trợ phác đồ $4 A C-4 T$, tia xạ bổ trợ. Bệnh nhân tái phát di căn phổi sau xạ trị 10 tháng chuyển điêu trị hóa chất triêu chứng và tử vong sau xa trị 15 tháng. Kết quả nghiên cứu của chúng tôi phù hợp với các nghiên cứu của các tác giả khác như nghiên cứu Milan III cho kết quả sống thêm toàn bộ sau 5 năm 92\% [7].

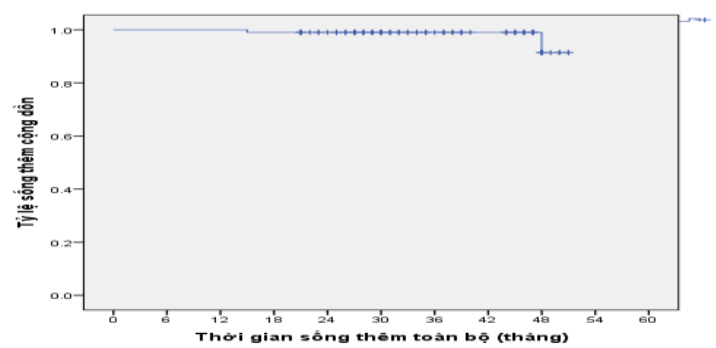

khác. Theo Hoàng Thanh Quang trên 64 bệnh nhân UTV giai đoạn I, II điều trị bảo tồn kết hợp xạ trị bổ trợ, tỷ lệ sống thêm không bệnh 5 năm 
là 85,5\%. Nghiên cứu của Ta Xuân Sơn tỷ lệ sống thêm không bệnh tại 4 năm là 92,5\% [8][9]

Trong nghiên cứu có 1 bệnh nhân tái phát tại chỗ tại thời điểm 38 tháng, 3 bệnh nhân tái phát di căn xương, 1 bệnh nhân tái phát di căn gan. Một trường hợp tái phát tại chỗ là bệnh nhân trẻ 30 tuổi, chẩn đoán $K$ vú (P) T1NOM0 được điều trị bảo tồn kết hợp xạ trị bổ trợ. Giải phẫu bệnh là thể tủy, thụ thể nội tiết âm tính, Her2/neu, âm tính, Ki67 dương tính 80\%. Bệnh nhân được điều trị hóa chất toàn thân $4 F A C-4 \mathrm{~T}$.

Kết quả thẩm mỹ vú bảo tôn sau xạ trị. Mục tiêu của điều trị ung thư vú là đạt kết quả kiểm soát ung thư tối ưu, bên cạnh đó kết quả thẩm mỹ rất được quan tâm vì nó ảnh hưởng rất lớn đến tâm lý, chất lượng sống của người bệnh. Theo kết quả nghiên cứu của các tác giả từ năm 1969 đến năm 1996, khoảng 70-87\% bệnh nhân có kết quả thẩm mỹ đạt mức đẹp hoặc tốt [10]. Các yếu tố phẫu thuật ảnh hưởng đến thẩm mỹ bao gồm thể tích cắt bỏ, sẹo mổ, cũng như diện tích da bị cắt bỏ $>20 \mathrm{~cm}^{2}$ [137]. Xạ trị ảnh hưởng đến thẩm mỹ bao gồm thể tích xạ trị, liều xạ vú và giường u, cũng như sự phân bố liều xạ tại thể tích điều trị.

Tại thời điểm 60 tháng chúng tôi thấy kết quả thẩm mỹ đẹp chiếm $37,6 \%$, tốt chiếm $20,8 \%$, trung bình chiếm $21,8 \%$, kém chiếm $19,8 \%$; có 1 bệnh nhân tử vong và 1 bệnh nhân tái phát tại chố trước thời điểm đánh giá. Theo kết quả của một số nghiên cứu, trên 30\% bệnh nhân không hài lòng về hình thể tuyến vú sau phẫu thuật bảo tồn. Nguyên nhân chính được đưa ra bao gồm: thiếu hụt mô tuyến, co kéo da gây biến dạng vú, co kéo/thay đổi vị trí phức hợp quầng-núm vú, mất cân đối hai vú và các tác dụng muộn của xạ trị tới bên vú phẫu thuật.

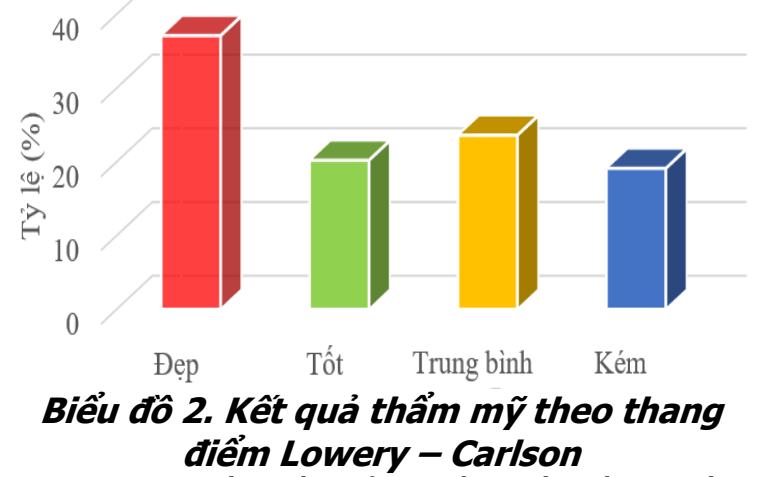

Trong nghiên cứu của chúng tôi có 34 bệnh nhân (33\%) được phẫu thuật bảo tồn kèm tạo hình tuyến vú. Khi phân tích yếu tố liên quan giữa kết quả thẩm mỹ và phương pháp phẫu thuật, chúng tôi chưa tìm thấy sự khác biệt có ý nghĩa thống kê giữa hai nhóm bệnh nhân có hoặc không kèm theo phẫu thuật tạo hình. Một lý do có thể giải thích là hầu hết các trường hợp bệnh nhân được phẫu thuật thuật tạo hình trong nghiên cứu của chúng tôi là do kích thước u lớn, gần vị trị trung tâm và các phương pháp tạo hình chủ yếu là dịch chuyển mô vú. Một lý do khác là do số lượng bệnh nhân giữa hai nhóm còn thấp và chưa cân xứng nhau.

Bảng 2. Phân tích đa biến các yếu tố liên quan kêt quả thẩm mỹ

\begin{tabular}{|c|c|c|}
\hline Yếu tố & B & $\mathbf{p}$ \\
\hline Tuối ( $\leq 50$ sv > 50 tuối) & $-0,170$ & 0,745 \\
\hline $\begin{array}{c}\text { Thế tích vú }(\leq 500 \mathrm{cc} \text { sv }>500 \\
\mathrm{cc})\end{array}$ & 0,145 & 0,790 \\
\hline Kích thước u $(\leq 2 \mathrm{~cm} \mathrm{sv}>2 \mathrm{~cm})$ & 0,122 & 0,831 \\
\hline Vị trí u (trong sv ngoài) & 0,014 & 0,978 \\
\hline $\begin{array}{l}\text { Phương pháp phâu thuật } \\
\text { (không sv có tạo hình) }\end{array}$ & $-0,643$ & 0,216 \\
\hline
\end{tabular}

Tác giả Taylor $\mathrm{ME}$ và Mills $\mathrm{JM}$ cho rằng khi thể tích mô vú bị cắt bỏ (bao gồm cả u) lớn hơn $100 \mathrm{~cm}^{2}$ có nguy cơ dẫn tới kết quả thẩm mỹ kém sau phẫu thuật nếu chỉ cắt rộng $\mathrm{u}$ đơn thuần. Tương ứng với tỷ lệ thể tích tuyến vú (bao gồm cả u) bị cắt bỏ trên $10 \%$ sẽ dẫn tới kết quả thẩm mỹ kém. Các tác giả đều cho rằng tỷ lệ kích thước u-kích thước tuyến vú có giá trị hơn kích thước $u$ đơn thuần trong tiên lượng kết quả thẩm mỹ sau phẫu thuật. Với các bệnh nhân phải tiến hành cắt lại do diện cắt dương tính, tỉ lệ kết quả thẩm mỹ thấp hơn các bệnh nhân không phải cắt lại. Vị trí u cũng ảnh hưởng tới kết quả thẩm mỹ, các khối u ở 1/2 dưới hoặc trung tâm tuyến vú cho kết quả thẩm mỹ kém hơn các khối u ở vị trí còn lại. Với các khối u nằm ở $1 / 2$ trong, do sự phân bố ít của mô tuyến ở khu vực này, thể tích tuyến vú cho phép cắt bỏ trong phẫu thuật là không quá $5 \%$ để đảm bảo kết quả thẩm mỹ sau phẩu thuât. Hình dang tuyến vú trước điều trị cũng ảnh hưởng tới kết quả thẩm mỹ. ở phụ nữ lớn tuổi, mô tuyến vú được thay thế bằng mô xơ-mõ̃, tổ chức da và mô nâng đõ tuyến vú cũng thay đổi, dẫn tới thay đổi về hình thể tuyến vú. Tác giả Taylor $\mathrm{ME}$ và $\mathrm{CS}$ cho rằng kết quả thẩm mỹ của nhóm bệnh nhân trên 60 tuổi kém hơn so với nhóm bệnh nhân trẻ hơn.

Các tác giả Kaur N và CS (2005), Schrenk $P$ và CS (2006), Giacalone PL và CS (2007) tiến hành nghiên cứu so sánh giữa hai nhóm bệnh nhân được phấu thuât bảo tồn kết hợp tạo hình và phẫu thuật bảo tồn đơn thuần cho thấy kích thước $u$ được bảo tồn lớn hơn, thể tích mô vú cắt được lớn hơn, tỷ lệ diện cắt âm tính và độ 
dầy diện cắt âm tính lớn hơn. Trong nhóm này, tỷ lệ phải phẫu thuật cắt thêm cũng thấp hơn. Kết quả thẩm mỹ của nhóm kết hợp tạo hình tốt hơn nhóm cắt rộng u đơn thuần.

\section{KẾT LUẬN}

Trong nghiên cứu, độ tuổi bệnh nhân khá trẻ, trẻ nhất 21 , vị trí u $1 / 4$ trên ngoài thường gặp nhất, giai đoạn I -IIA là chủ yếu. Thể tích vú trung bình và nhỏ chiếm đa số $90,3 \%$. Thời gian sống thêm không bệnh 5 năm là $92,6 \%$, sống thêm toàn bộ 5 năm là $95,6 \%$. Kết quả thẩm mỹ mức đạt chiểm 80,2\%. Các biến chứng của xạ trị ảnh hưởng đến kết quả thẩm mỹ thường xảy ra muộn vậy cần có theo dõi dài sau điều trị để có những kết luận chính xác hơn

\section{TÀI LIÊU THAM KHẢO}

1. GLOBOCAN (2018). Incidence, Mortality and Prevalence by cancer site, <https://gco.iarc.fr/today/ data/factsheets/cancers/ 20-Breast-fact-

2. Harsolia A, Kestin L, Grills I, Wallace M, Jolly $\mathbf{S}$, Jones $\mathbf{C}_{\text {, }}$ et al. "Intensity-modulated radiotherapy 2 . results in significant decrease in clinical toxicities compared with conventional wedge-based breast radiotherapy"'". Int J Radiat Oncol Biol Phys. 2007;68(5):1375-80.

4. Losken, C. S. Dugal, T. M. Styblo et al. (2014). A meta-analysis comparing breast conservation therapy alone to the oncoplastic technique. Ann Plast Surg, 72(2), 145 - 152

5. Pham Hồng Khoa (2016). Ung dụng phương pháp sinh thiết hạch cửa trong điều trị ung thư biểu mô tuyến vú giai đoạn sớm, Luận án Tiến sỹ Y học, Trường Đại học Y Hià Nội.

6. J. P. Pignol, I. Olivotto, E. Rakovitch et al. (2008). A multicenter randomized trial of breast intensity-modulated radiation therapy to reduce acute radiation dermatitis. J Clin Oncol, 26(13), 2085-92.

7. Tạ Văn Tờ (2004). Nghiên cứu hình thái học, hóa mô miễn dịch và giá trị tiên lượng của chúng trong ung thư biểu mô tuyến vú, Luận án Tiến sỹ Y học, Trường Đại học Y Hà Nội.

8. U. Veronesi, A. Luini, M. Del Vecchio et al. (1993). Radiotherapy after breast-preserving surgery in women with localized cancer of the breast. N Engl J Med, 328(22), 1587-91.

9. Hoàng Thanh Quang (2011). Đánh giá kết quả điều trị bảo tồn ung thư vú nữ giai đoạn I-II từ năm 2003-2006 tại Bệnh viện K, Luận văn Thạc sỹ Y học, Trường Đại học Y Hà Nội.

\section{ĐÁNH GIÁ KẾT QUẢ HÓA TRỊ BỔ TRỢ PHÁC ĐỒ 4AC-4D TRÊN BỆNH NHÂN UTV GIAI ĐOẠN II -IIIA BỆNH VIỆN UNG BƯỚU THANH HÓA}

\section{TÓM TẮT}

Mưc tiêu: Đánh giá kết quả sống thêm và một số yễu tổ liên quan trên bệnh nhân ung thư vú giai đoạn II-IIIA điều trị phác đồ hóa chất bổ trợ $4 \mathrm{AC}-4 \mathrm{D}$ (A: doxorubicine, $\mathrm{C}$; cyclophosphamide và $\mathrm{D}$ : docetaxel) áp dụng tại Bệnh viện Ung bướu Thanh Hóa. Đối tượng và phương pháp nghiên cứu: Bao gồm 74 bệnh nhân được chẩn đoán ung thư vú giai đoạn IIIIIA đã phẫu thuật triêtt căn, điêu trị hóa chất bổ trợ tại bệnh viện ung bướu Thanh Hóa, từ tháng 2 năm 2014 đến tháng 4 năm 2021. Kết quả: Tuổi trung bình của nhóm nghiên cứu là 46,62 $\pm 7,05$ tuổi.Tất cả 74 bệnh nhân đều hoàn thành 8 chu kỳ hóa chất $4 A C-$ $4 \mathrm{D}$, không có bệnh nhân nào dừng điêu trị. Thời gian nghiên cứu trung bình là 69 tháng, tỷ lệ sông thêm không bệnh sau 5 năm là $53,6 \%$ với thời gian sống thêm khống bệnh trung bình là $63,95 \pm 2,34$ tháng, tỳ

\footnotetext{
${ }^{1}$ Trường Đại học Y Hà Nội

²Bênh viên $K$

Chịu trách nhiệm chính: Nguyễn Thị Trang

Email: drtrang1989@gmail.com

Ngày nhận bài: 3.8.2021

Ngày phản biện khoa học: 5.10 .2021

Ngày duyệt bài: 15.10 .2021
}

Nguyễn Thị Trang ${ }^{1}$, Phạm Hồng Khoa ${ }^{2}$

lệ sống thêm toàn bộ sau 5 năm là $89,2 \%$ với thời gian sống thêm toàn bộ trung bình là $78,70 \pm 1,60$ tháng. Các yếu tố ảnh hưởng đến điều trị bao gồm giai đoạn bệnh, tình trạng thụ thể nội tiết, tình trang HER2. Kết luận: Áp dụng phác đồ 4AC-4D trên bệnh nhân ung thư vú bổ trợgiai đoạn II-IIIA tại bệnh viện Ung bướu Thanh Hóa có hiệu quả cao. bổ trợ.

Tư khóa: ung thư vú giai đoạn II-IIIA, 4AC-4D,

\section{SUMMARY \\ TREATMENT OUTCOME IN PATIENTS WITH STAGE II-IIIA BREAST CANCER TREATED \\ WITH ADJUVANT CHEMOTHERAPY IN \\ THANH HOA ONCOLOGY HOSPITAL}

Objectives: To evaluate survival outcomes and some related factors in patients with stage II-IIIA breast cancer treated with 4AC-4D (A: doxorubicine, C: cyclophosphamide and D: docetaxel) adjuvant chemotherapy. Subjects and methods: Including 74 patients diagnosed with breast cancer stage II-IIIA who underwent radical surgery, adjuvant chemotherapy at Thanh Hoa Oncology Hospital, from February 2014 to April 2021. Results: The mean age of the study group was $46.62 \pm 7.05$ years. All 74 patients completed 8 cycles of 4AC-4D chemotherapy, 
none of which stopped treatment. The mean study time was 69 months, the 5 -year disease-free survival rate was $53.6 \%$ with the mean disease-free survival time was $63.95 \pm 2.34$ months, the overall survival rate after 5 years was $89.2 \%$ with a mean overall survival time of $78.70 \pm 1.60$ months. Factors affecting treatment include stage, hormonal receptor status and HER2 status. Conclusion: Applying the 4AC-4D regimen on patients with stage II-IIIA adjuvant breast cancer at Thanh Hoa Oncology Hospital has high efficiency.

Keywords: breast cancer stage II-IIIA, 4AC-4D, adjuvant.

\section{I. ĐẶT VẤN ĐỀ}

Ung thư vú(UTV) là một bệnh lý toàn thân, đặc biệt khi xuất hiên di cằn hạch nách, điêu trị không còn là tại chỗ, tại vùng mà đó là sự kết hợp điều trị đa mô thức giữa các phương pháp phấu thuật, xạ trị, hóa chất, nội tiết và sinhhọc. Việc áp dụng một hay nhiều phương pháp điều trị là tùy thuộc vào mỗi trường hợp cụ thểnhư giai đoạn bệnh, loại mô học, tình trạng thụ thể nội tiết, yếu tố phát triển biểu mô, tuổi, toàn trạng và một số yếu tố khác.

Hóa trị bổ trợ sau phẫu thuật đóng vai trò quan trọng trong điêu trị ung thư vú ở giai đoạn sớm, mục đích tiêu diệt các tế bào ung thư vi di căn, giảm tái phát và kéo dài thời gian sống thêm cho người bệnh. Nhóm Anthracyclin đã được chứng minh là một trong các thuốc có hiệu quả cao trong điều trị ung thư vú, với tỷ lệ đáp ứng $41 \%$ khi dùng đơn độc và $62-70 \%$ khi phối hợp với các thuốc khác ở bệnh nhân chưa điều trị hóa chất ${ }^{1-4}$. Vì vậy, hầu hết các phác đồ hóa chất trong điêu tri ung thư vú đều có Anthracyclin.

Hiện nay phác đồ 4AC-4D đã được sử dụng rất rộng rãi và trở thành quy trình chuẩn trong điều trị UTV bổ trợ trước và bổ trợ sau phẫu thuật đối với nhiều nước trên thế giới cũng như ở Việt Nam. Tại bệnh viện Ung bướu Thanh Hóa chưa có nghiên cứu nào về vai trò hóa trị bổ trợ trong ung thư vú. Chính vì vậy chúng tôi nghiên cứu đề tài: Đánh giá kêt quả hóa trị bổ trợ phác đồ $4 A C-4 D$ bệnh nhân ung thư vú giai đoạn II-IIIA.
II. ĐỐI TƯỢNG VÀ PHƯƠNG PHÁP NGHIÊN CỨU 2.1. Đối tượng nghiên cứu:

- Tiêu chuẩn lựa chọn:

+ Bệnh nhân nữ chẩn đoán là UTV giai đoạn

II-IIIA và $\leq 70$ tuổi.

+ Được phẫu thuật triệt căn.

+ Được hóa chất bổ trợ sau phẫu thuật phác đồ 4AC-4D, điều trị nội tiết, xạ trị.

+ Không mắc ung thư khác.

+Không có bệnh chống chỉ định với thuốc Anthracyclin: các bệnh lý tim mạch nặng như suy tim, viêm cơ tim, nhồi máu cơ tim, phân suất tông máu trên siêu âm tim $\geq 50 \%$.

+ Chức năng gan, thận và tủy xương trong giới hạn bình thường.

+ Có đầy đủ hồ sơ bệnh án lưu trữ.

- Tiêu chuẩn loại trừ: không đáp ứng đủ tiêu chí trên.

\subsection{Phương pháp nghiên cứu}

- Thiết kế nghiên cứu: Nghiên cứu mô tả hồi cứu.

- Thời gian và địa điểm nghiên cứu:

+ Thời gian nghiên cứu từ tháng 02/2014 đến tháng 04/2021.

+ Địa điểm nghiên cứu tại Bệnh viện Ung bướu tỉnh Thanh Hóa.

-Phương pháp thu thập số liệu:

+ Thu thập số liệu theo mẫu bệnh án

+ Tất cả các thông tin thu thập từ hồ sơ bệnh án

- Phân tích số liệu: nhập liệu, xử lý và phân tích trênmáy tính bằng phần mềm SPSS 20.0

\section{KẾT QUẢ NGHIÊN CỨU}

\section{1. Đặc điểm đối tượng nghiên cứu}

3.1.1. Tuổi và giai đoạn bệnh. Trong số 74 bệnh nhân nghiên cứutuổi trung bình là 46,62 \pm 7,05. Nhóm tuổi cao nhất 40-49 có tỷ lệ 44,6\%.

3.1.2. Giai đoạn bệnh. Giai đoạn IIA chiếm tỷ lệ cao nhất 40,5\%; giai đoạn IIB là $25,7 \%$; giai đoạn IIIA có tỷ lệ 33,8\%.

\subsubsection{Hóa mô miển dịch}

Bảng 1. Hóa mô miễn dịch

\begin{tabular}{|c|c|c|c|c|c|c|}
\hline \multirow{2}{*}{ Thụ thể bộc lộ trên u u } & \multicolumn{2}{|c|}{ Dương tính } & \multicolumn{2}{c|}{ Âm tính } & \multicolumn{2}{c|}{ Tổng } \\
\cline { 2 - 7 } & Số BN (n) & Tỉ lệ (\%) & Số BN(n) & Tỉ lệ(\%) & Số BN(n) & Tỉ lệ(\%) \\
\hline ER & 49 & 66,2 & 25 & 33,8 & 74 & 100 \\
\hline PR & 53 & 71,6 & 21 & 28,4 & 74 & 100 \\
\hline ER và hoặc PR & 65 & 87,8 & 9 & 12,2 & 74 & 100 \\
\hline Thụthể HER2(2+),(3+) & 24 & 32,4 & 50 & 67,6 & 74 & 100 \\
\hline
\end{tabular}

Nhận xét: Tỷ lệthụ thể nội tiết (TTNT) dương tính cao 87,8\%. Tỷ lệHER2 âm tính 67,6\%; tỷ lệ HER2 dương tính (cả HER2 dương tính 2+ và 3+) thấp chiếm 32,4\%.

\subsection{Tỷ lệ sống thêm}

\subsubsection{Thời gian sống thêm}



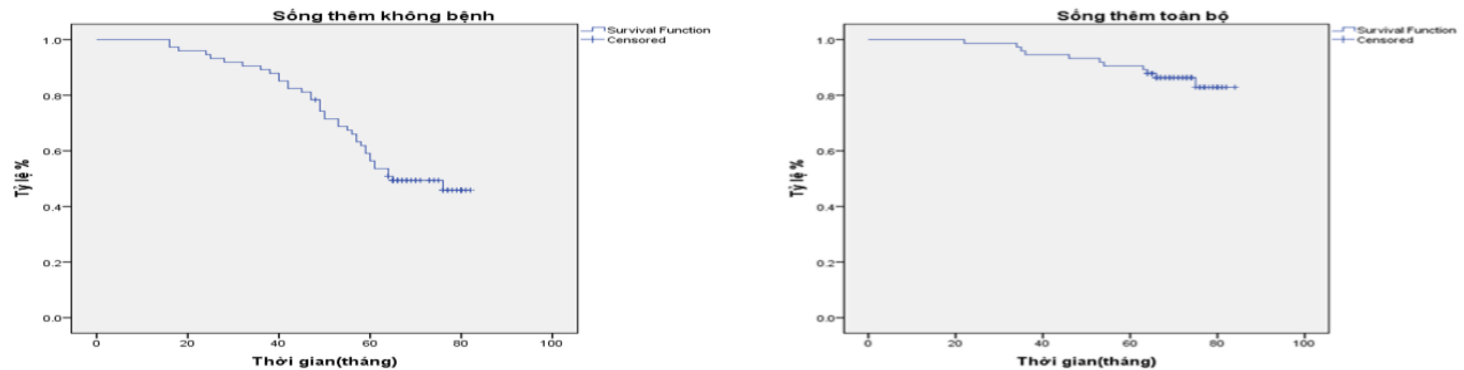

Biểu đồ 1: Tỷ lệ sống thêm không bệnh và sông thêm toàn bộ

Nhận xét: Tỷ lệ DFS $>5$ năm là $53,6 \%$; thời gian sống thêm không bệnh trung bình là $63,95 \pm$ 2,34 tháng. Tỷ lệ OS>5 năm là $89,2 \%$; thời gian sống thêm toàn bộ trung bình là $78,70 \pm 1,60$ tháng.

\subsubsection{Một số yếu tố liên quan đến sông thêm}
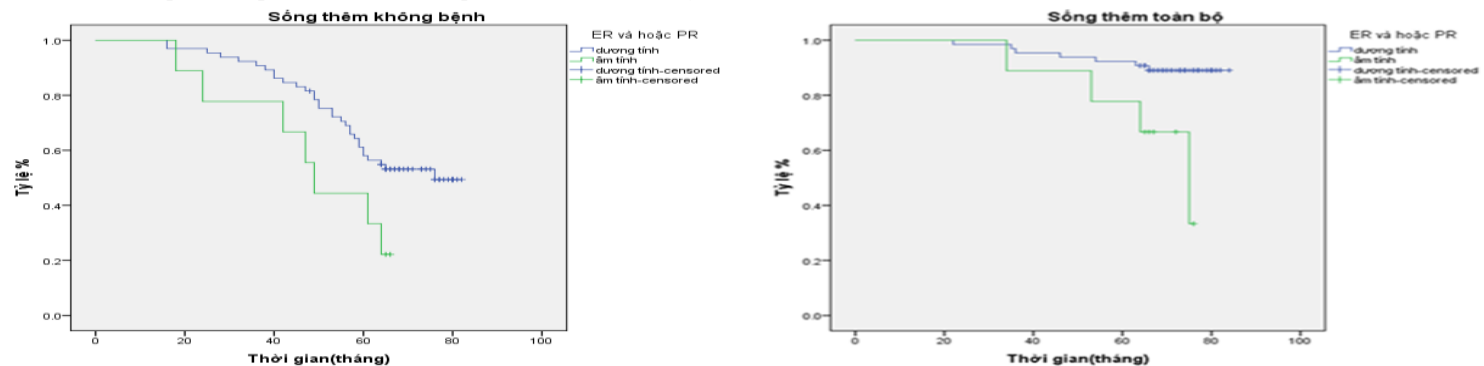

Biểu đồ 3: Sống thêm không bệnh theo tình trạng thụ thể nội tiêt

Nhận xét: Tỷ lệ DFS >5 năm của nhóm có TTNT dương tính chiếm tỷ lệ $58 \%$; còn nhóm có thụ thể nội tiết dương tính là 90,8\%; giảm xuống còn $66,7 \%$ ở nhóm có thụ thể nội tiết âm tính, với $\mathrm{p}<0.05$.
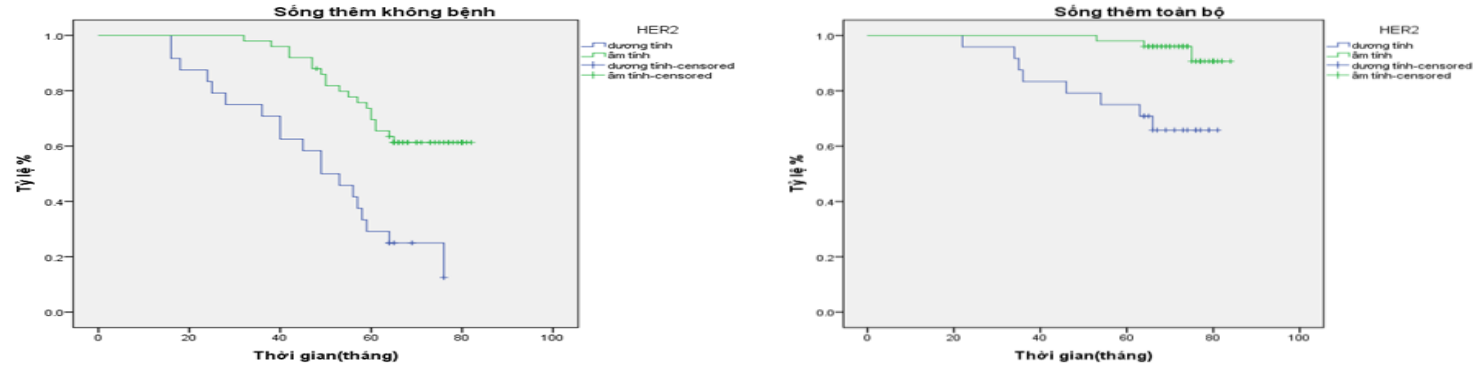

\section{Biểu đồ 4: Sống thêm không bênh theo tình trang thu Her2}

Nhận xét: Tỷ lệ DFS > 5 năm của nhóm Her2(-) là $65,5 \%$; nhóm HER2(+) là $25 \%(p<0,05)$. Tỷ lệ OS > 5 năm của nhóm HER2(-) là $96 \%$; còn nhóm HER2 $(+)$ là $70,8 \%(p<0,05)$.

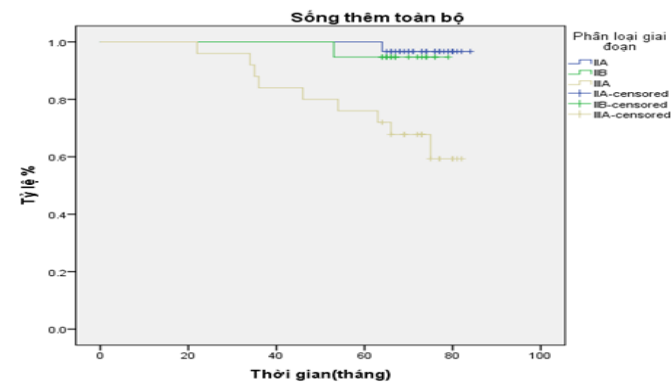

Biểu đồ 2: Sông thêm không bệnh theo giai đoạn bệnh

Nhận xét: Tỷ lệ DFS $>5$ năm giai đoạn IIA, IIB, IIIA cólần lượt là 70\%; 42,1\%; 34,3\% $(p<0,05)$. Tỷ lệ OS> 5 năm giai đoạn IIA, IIB, IIIA lân lượt là 96,7\%; 94,7\%; 72\% ( $p<0,05)$.

\section{BÀN LUẬN}

4.1. Đặc điểm bệnh nhân. Trong nghiên cứu của chúng tôi bệnh nhân cao tuổi nhất là 60 tuổi, trẻ tuổi nhất là 31 tuổi. Đây là độ tuổi phù hợp với một số nghiên cứu của các tác giả trong nước như Lê Thị Sương, Trần Văn Thuấn ${ }^{5,6}$.

Giai đoạn bệnh: là một yếu tố quan trọng liên quan đển tiên lượng cũng như điều trị trong 
UTV. Giai đoạn bệnh càng cao thì tiên lượng càng xâu, sau điều trị thường có nguy cơ tái phát cao. Theo nghiên cứu của Lê Thị Sương cho tỷ lệ giai đoạn IIA, IIB, IIIA lần lượt là $43,8 \%$; $25 \% ; 31,3 \%{ }^{6}$. Kết quả này cũng tương tự nghiên cứu của chúng tôi chủ yếu là giai đoạn IIA với tỷ lệ $40,5 \%$; sau đến giai đoạn IIIA chiếm tỷ lệ $33,8 \%$; cuối cùng là giai đoạn IIB là 25,7\%.

Tình trạng thụ thể nội tiết: thụ thể nội tiết Esstrogen và/ hoặc Progesteron dương tính đáp ứng tốt hơn với điều trị nội tiết, đồng thời tỷ lệ tái phát, di căn thấp hơn và có thời gian sống thêm lâu hơn so với nhóm có TTNT âm tính. Tỷ lệ bệnh nhân có thụ thể nội tiết dương tính (ER và hoặc $P R$ ) là $87,8 \%$; âm tính chỉ chiếm $12,2 \%$. Theo nghiên cứu của Tạ Văn Tờ tỷ lệ thụ thể nội tiết dương tính là 63,3\%; âm tính là 36,6\%7 .

Tình trạng HER2: Bệnh nhân có tý lệ HER2 dương tính là $32,4 \%$; còn dương tính là $67,6 \%$. Cũng tương tự kết quả của T. V. Tờ khi nghiên cứu trên 2207 bệnh nhân cho tỷ lệ Her2 dương tính là $35,1 \%$.

\subsection{Kêt quả điêu trị}

4.2.1. Thời gian sống thêm. Tỷ lệ sống thêm không bệnh sau 5 năm là $53,6 \%$ với thời gian sống thêm không bệnh trung bình là 63,95 $\pm 2,34$ tháng. Tỷ lệ sống thêm toàn bộ sau 5 năm là $89,2 \%$ với thời gian sống thêm toàn bộ trung bình là $78,70 \pm 1,60$ tháng. Kết quả của chúng tôi cao hơn kết quả của Lê Thị Sương khi nghiên cứu trên 32 bệnh nhân cho tỷ lệ sống thêm không bệnh 1 năm, 2 năm, 3 năm lần lượt là $100 \%$; $91,4 \% ; 86,9 \%{ }^{6}$; tỷ lệ sống thêm toàn bộ 1 năm, 2 năm, 3 năm lần lượt là $100 \%$; 95,5\%; 95,5\%; có lẽ do cõ mẫu của chúng tôi lớn hơn. Theo Lý Thị Thu Hiên nghiên cứu trên 103 bệnh nhân UTV có bộ ba âm tính điêu trị bổ trợ 4AC - 4D cho thời gian sống thêm không bểnh 1 năm, 2 năm, 3 năm, 4 năm, 5 năm lần lượt là $95,1 \% ; 93,2 \% ; 92,2 \% ; 89,9 \% ; 89,9 \%$ và thời gian sống thêm toàn bộ 1 năm, 2 năm, 3 năm, 4 năm lần lượt là $100 \% ; 95,1 \%$; 94\%; $90,3 \% ; 90,3 \% 8$.

\subsubsection{Một số yếu tố liên quan đến thời gian sống thêm}

Giai đoạn bệnh: Theo nghiên cứu của chúng tôi giai đoạn bệnh có mối liên quan đến sống thêmtheo tỳ lệ nghịch $(p<0,05)$,giai đoạn càng cao thì thời gian sống thêm càng giảm. Cụ thể trên với các giai đoan IIA, IIB, IIIA cho DFS sau 5 năm lần lượt là $70 \% ; 42,1 \% ; 34,3 \%$; còn tỷ lệ OS sau 5 năm lần lượt là $96,7 \% ; 94,7 \% ; 72 \%$. Nghiên cứu của Trần Văn Thuấn cũng cho tỷ lệ sống thêm không bệnh và sống thêm toàn bộ 4 năm ở giai đoạn II là $92,3 \%$ và $96,1 \%$ giảm xuống còn $65,8 \%$ và $78,2 \%$ ở giai đoạn III $^{5}$.

Thu thể nội tiết: Thu thể nội tiết ầm tính liên quan đến tiên lượng xấu hơn nhóm thụ thể nội tiết dương tính. Trong nghiên cứu của chúng tối tỷ lệ DFS $>5$ năm của nhóm có thụ thể nội tiết dương tính chiếm tỷ lệ gần $58 \%$; còn nhóm có thụ thể nội tiết âm tính chỉ chiếm 33,3\%. Tỷ lệ OS >5 năm của nhóm có thụ thể nội tiết dương tính là $90,8 \%$; giảm xuống còn $66,7 \%$ ở nhóm có thụ thể nội tiết âm tính. Nghiên cứu của Đỗ Thị Kim Anh cũng cho thấy có sự khác biêt về thời gian sống thêm không bệnh và sống thêm toàn bộ ở nhóm có TTNT dương tính và nhóm TTNT âm tính ${ }^{9}$.

Tình trạng Her2: Sự biểu hiện quá mức thụ thể phát triển biểu mô là một yếu tố tiên lượng không tốt, đặc biệt trong trường hợp không được điều trị trúng đích Her2. Theo Trần Văn Thuấn khi phẩn tích đơn biến về ảnh hưởng của Her2 đến kết quả sống thêm sau 4 năm thì tỷ lệ sống thêm không bệnh và sông thêm toàn bộ ở nhóm Her2 âm tính là $82,1 \%$ và $98,51 \%$ cao hơn so với $57,81 \%$ và $77,37 \%$ ở nhóm Her2 dương tính, với $p<0,05^{5}$. Tương tự kết qủa của chúng tôi tỷ lệ DFS sau 5 năm của nhóm Her2(-) là 65,5\%; giảm xuống $25 \%$ ở nhóm Her2(+). Tỷ lệ OS sau 5 năm ở hai nhóm trên lần lượt là $96 \%$ và $70,8 \%$. Sự khác biệt này có ý nghĩa thống kê với $p<0,05$.

\section{KẾT LUÂ̂N}

Bệnh nhân nghiên cứu có độ tuổi trung bình 46,6 tuổi. Giai đoạn IIA có tỷ lệ 40,5\%; tiếp đến giai đoan IIIA chiếm tỷ lê $33,8 \%$; và giai đoan IIB là 25,7\%. Tỷ lệ TTNT dương tính cao 87,8\%; tình trạng HER2 âm tính có tỷ lệ 76,6\%.

74 bệnh nhân UTV giai đoạn II-IIIA được điều trị hóa chất bổ trợ phác đồ $4 A C-4 D$, thời gian sống thêm không bệnh sau 5 năm trung bình là $63,95 \pm 2,34$ tháng và thời gian sống thêm toàn bộ sau 5 năm là $78,70 \pm 1,60$ tháng. Giai đoạn bệnh, tình trạng TTNT và HER2 là những yếu tố tiên lượng quan trong có liên quan đến kết quả sống thêm trong nhóm nghiên cứu.

Phác đồ $4 A C-4 D$ là phác đồ có hiệu quả cao cho bệnh nhân ung thư vú giai đoạn II-IIIA bổ trợ tại bệnh viện Ung bướu Thanh Hóa.

\section{TÀI LIỆU THAM KHẢO}

1. Paridaens R., Biganzoli L., Bruning P., et al. (2000). Paclitaxel versus doxorubicin as first-line single-agent chemotherapy for metastatic breast cancer: a European Organization for Research and Treatment of Cancer Randomized Study with cross-over. J Clin Oncol, 18(4), 724-733. 
2. Falkson G, Gelman RS, Tormey DC, Cummings FJ, Carbone PP, Falkson HC. The Eastern Cooperative Oncology Group experience with cyclophosphamide, adriamycin, and 5fluorouracil (CAF) in patients with metastatic breast cancer. Cancer. 1985;56(2):219-224. doi:10.1002/1097-0142(19850715)56:2<219::aidcncr2820560202>3.0.co;2-q

3. Tranum BL, McDonald B, Thigpen $T$, et al. Adriamycin combinations in advanced breast cancer. A Southwest Oncology Group Study. Cancer. 1982;49(5):835-839. doi:10.1002/10970142(19820301)49:5<835: :aidcncr2820490502>3.0.c0;2-z

4. Taylor SG, Gelber RD. Experience of the Eastern Cooperative Oncology Group with doxorubicin as a single agent in patients with previously untreated breast cancer. Cancer Treat Rep. 1982; 66(7): 1594-1595.
5. Trân Văn Thuấn. Đánh giá kết quả điều trị bổ trơ hóa chất phác đồ Adriamycin-Cyclophosphamid kết hợp với điêu trị nội tiết trên bệnh nhân ung thư vú giai đoạn II-III. Luânn văn tiến sỹ; 2005.

6. Lê Thị Sương. Đánh giá kết quả điều trị bổ trơ ung thư vú giai đoạn II-IIIA bằng phác đồ 4AC-4D Luấn văn thac sỹ; 2017.

7. Ta Văn Tờ. Nghiên cứu hình thái hoc, hóa mô miễn dịch và giá trị tiên lượng của chúng trong ung thư biểu mô tuyến vú. Luận văn Tiển sỹ Y hoc; 2004.

8. Lỳ Thi Thu Hiên. Đánh giá hiệu quả điều tri bổ trợ phác đồ 4AC- 4D trên bệnh nhân ung thư vú có bố ba âm , Luận văn thạc sỹ்; 2018.

9. Đố Thi Kím Ành. Đánh giá kết quả hóa chất bổ trơ phác đồ 4AC-4P trên bệnh nhân ung thư vú gia đoạn II-III tại bệnh viện K luận văn thạc sỹ; 2008.

\section{TÌM HIỂU VAI TRÒ CỦA TỶ LÊ SV2/RV3 TRÊN ĐIÊN TÂM ĐỒ TRONG CHẨN ĐOÁN PHÂN BIÊT NGOAI TÂM THU THẤT Có NGUÔNN GỐC ĐƯờNG RA THẤT PHẢI VÀ ĐƯỜNG RA THẤT TRÁI}

\section{TÓM TẮT}

Các rối loạn nhip thất trên người không có bênh tim thực tổn, hay còn được gọi là các rối loạn nhịp thất vồ căn (idiopathic ventricular arrhythmias), đa phần đều khởi phát từ đường ra tâm thất. Phân biệt ngoai tâm thu thất từ đường ra thất phải và đường ra thất trái chẩn đoán còn khó khăn, đặc biệt là rối loạn nhịp thất có dạng block nhánh trái với chuyển tiếp tại V3. Mục tiêu của nghiên cứu chúng tôi là: mô tả các đặc điểm điện tâm đồ bề mă̆t của ngoại tâm thu thất có nguồn gốc từ đường ra thất phải và đường ra thất trái; đồng thời tìm hiểu vai trò của tỷ lệ SV2/RV3 trên điện tâm đồ bề mặt trong chẩn đoán phân biệt ngoại tâm thu thất có nguồn gốc ở đường ra thất trái và đường ra thất phải. Đối tượng và phương pháp nghiến cứu: mô tả cắt ngang 150 bệnh nhân ngoại tâm thu thất không có bênh tim thực tổn và có chì định thăm dò điện sinh lý và điều trị RF. Kết quả nghiên cứu: chúng tôi tiến hành nghiên cứu 150 bệnh nhân có ngoại tâm thu thất dạng block nhánh trái đã được thăm dò điên sinh lý và triệt đốt RF thành công ở đường ra thất phải (ĐRTP; $n=110$ ) hoăc đường ra thất trái (ĐRTT; $n=40$ ). Các kích thước biển độ sóng được đo đạc bằng thước cặp điện tử. Tỷ lệ SVं2/RV3 chính là biên độ sóng $S$ ở chuyển đao V2 chia cho biên độ sóng $R$ ở chuyển đạo V3 của nhịp ngoại tâm thu thất. Kết quả chỉ số SV2/RV3 ở đường

*Bênh viện Thanh Nhàn Hà Nội,

**Viên Tim mach Viêt Nam-Bênh viên Bach Mai

Chịu trách nhiệm chính: Nguyễn Thị Lan Anh

Email: lananhnguyenthi0502@gmail.com

Ngày nhận bài: 10.8.2021

Ngày phản biên khoa hoc: 4.10 .2021

Ngày duyệt bài: 15.10 .2021

\section{Nguyễn Thị Lan Anh*, Phạm Trần Linh**}

ra thất trái nhỏ hơn đáng kể so với đường ra thất phải có ý nghĩa thống kê $(1,23 \pm 0,78$ so với $6,07 \pm 6,32$ và $p<0,001)$. Diện tích duới đường cong (AUC) cho chỉ số SV2/RV3 là 0,934 , với giá trị tới hạn là $\leq 1,6$ dứ đoán ngoại tâm thu thất đường ra thất trái với độ nhạy $90,9 \%$ và độ đặc hiệu là $80 \%$. Khi so sánh chỉ số này với 1 số các chỉ số khác ở cả nhóm bệnh nhân nghiên cứu và nhóm bệnh nhân có chuyển tiếp tại V3 chúng tôi nhận thấy chỉ số của chúng tôi cho kết quả cao nhất về giá trị dưới đường cong ROC và độ nhạy, độ đặc hiệu. Chỉ số này còn rất có giá trị ứng dụng lâm sàng cho các nhà nhịp hoc do tính toán khá dể dàng và nhanh chóng chỉ với điện tâm đồ thường quy 12 chuyển đạo. Kết luận: Chỉ số tỷ lệ SV2/RV3 rất có giá trị trong chẩn đoán phân biệt ngoại tâm thu thất đường ra thất trái và đường ra thất phải, hữu dụng trên thực hành lâm sàng cho các bác sỹ nhịp học.

Tư khóa: Ngoại tâm thu thất, Ngoại tầm thu thất đường ra thất, Điện sinh lý.

\section{SUMMARY}

\section{ROLE OF ELECTROCARDIOGRAPHIC SV2/RV3 RATIO IN DIFERENTIAL DIAGNISIS OF VENTRICULAR} EXTRASYSTOLE ORIGINATING FROM RIGHT VENTRICULAR OUTFLOW TRACT AND LEFT VENTRICULAR OUTFLOW TRACT

Introduction: Ventricular arrhythmias in humans without structural heart disease, also known as idiopathic ventricular arrhythmias, mostly originate in the ventricular outflow tract. Distinguishing ventricular extrasystoles from right ventricular outflow tract or left ventricular outflow tract remains challenging, especially in the form of ventricular arrhythmias with left bundle branch block with transition at V3. The 
objectives of our study were: to describe the surface electrocardiographic features of ventricular extrasystoles originating from right ventricular outflow tract and from left ventricular outflow tract; and also explore the role of SV2/RV3 ratio on surface electrocardiogram in differential diagnosis of ventricular extrasystoles originating in left ventricular outflow tract and right ventricular outflow tract. Methods: cross-sectional description of 150 patients with ventricular extrasystoles without structural heart disease having indications for electrophysiology study and RF ablation. Results: We conducted a study of 150 patients with left bundle branch block type ventricular extrasystoles who underwent electrophysiology study and successful RF ablation in the right ventricular outflow tract (RVOT; $n=110$ ) or left ventricular outflow tract (LVOT; $n=40$ ). The wave amplitude sizes were measured with an electronic caliper. The SV2/RV3 ratio is the S wave amplitude in lead V2 divided by the R wave amplitude in lead V3 of a ventricular ectopic beat. The results of SV2/RV3 index in the left ventricular outflow tract were statistically significant smaller than in the right ventricular outflow tract $(1.23 \pm 0.78$ versus $6.07 \pm$ 6.32 and $p<0.001$ ). The area under the curve (AUC) for the SV2/RV3 index was 0.934 , with a critical value of $\leq 1.6$ predicting left ventricular outflow tract extrasystoles with a sensitivity of $90.9 \%$ and a specificity of $80 . \%$. When comparing this index with a number of other indices in both the study group and the group of patients with transition at V3, we found that our index gives the highest result in terms of the value under the ROC curve and sensitivity and specificity. This index is also of great value in clinical applications for pacifiers because it is relatively easy and quick to calculate with only a 12-lead routine electrocardiogram. Conclusion: The SV2/RV3 ratio is very valuable in the differential diagnosis of left ventricular outflow tract and right ventricular outflow tract extrasystoles, and is useful in clinical practice for pacing physicians.

Key words; ventricular extrasystole, left ventricular outflow tract.

\section{I. ĐĂT VẤN ĐỀ}

Ngoai tâm thu thất là rối loan nhip tim khá thường gặp ${ }^{1}$.Phân biệt ngoại tẩm thu thất từ đường ra thất phải và đường ra thất trái thường dựa vào đặc điểm chuyển tiếp $R / S$ của các chuyển đạo trước tim, tuy nhiên chẩn đoán còn khó khăn giữa 2 dạng này, đặc biệt là rối loạn nhịp thất có dạng block nhánh trái với chuyển tiếp tại V3². Vì vậy chúng tôi tiến hành nghiên cứu này nhằm 2 mục tiêu:

1. Mô tả các đăc điểm điên tâm đồ bề măt của ngoại tâm thu thất có nguồn gốc từ đường ra thất phải và đường ra thất trái.

2. Tìm hiêu vai trò của tý lệ SV2/RV3 trên điện tâm đồ bề mặt trong chân đoán phân biệt ngoại tâm thu thất có nguồn gốc ở đường ra thất trái và đường ra thất phải.

\section{II. ĐỐI TƯợNG VÀ PHƯƠNG PHÁP NGHIÊN CứU}

- Đối tượng nghiên cứu là: 150 bệnh nhân có ngoại tâm thu thất vô căn dạng block nhánh trái đã được triệt đốt RF tại Viện Tim Mạch Bạch Mai từ tháng 8 năm 2020 đến 8 năm 2021.

- Phương pháp nghiên cứu là: nghiên cứu cắt ngang 150 bệnh nhân có ngoại tâm thu thất vô căn dang block nhánh trái, được thăm dò điện sinh lý và triệt đốt RF thành công xác định vị trí ổ ngoại tâm thu. Từ đó đối tượng được chia vào 2 nhóm ngoai tâm thu ở đường ra thất trái và đường ra thất phải. Các biên độ, thời gian sóng điện tâm đồ của nhịp xoang và ngoại tâm thu thất được đo đạc bằng thước cặp điện tử , đơn vị $\mathrm{mV}$ và $\mathrm{ms}$, từ đó tính toán các thông số sau:

+ Chỉ số tỷ lệ SV2/RV3: được tính bằng biên độ sóng $S$ tại chuyển đạo V2 chia cho biên độ sóng $\mathrm{R}$ tại chuyển đạo V3.

+ Chỉ số thời gian sóng $R$, chỉ số biên độ sóng $R, T Z$ index, chỉ số chuyển tiếp tại V2(V3).

+ Sử dụng thuật toán đường cong ROC để tính toán diện tích dưới đường cong (AUC), tìm điểm cut-off, xác định độ nhạy, độ đặc hiệu của tiêu chuẩn SV2/RV3 để phân biệt ngoại tâm thu thất đường ra thất trái và đường ra thất phải, so sánh với các tiêu chuẩn khác.

-Xü lý số liệu: Số liệu thống kê được phân tích và xử lý bằng phân mềm SPSS 20.0.

\section{KẾT QUẢ NGHIÊN CứU}

\section{1. Đặc điểm của đối tượng nghiên cứu:} 3.1.1. Đắc điểm chung:

Bảng 3.1: Đặc điểm chung của bệnh nhân nghiên cứu

\begin{tabular}{|c|c|c|c|c|c|}
\hline & $\begin{array}{c}\text { Nhóm chung } \\
(N=150)\end{array}$ & $\begin{array}{c}\text { ĐRTP } \\
(n=110)\end{array}$ & $\begin{array}{c}\text { DRTT } \\
(n=40)\end{array}$ & $\underset{*}{P \text { P Value }}$ \\
\hline \multicolumn{2}{|c|}{ Thế lâm sàng (\%) } & 100 & 73,3 & 26,7 & $<0,001$ \\
\hline \multirow{2}{*}{ Giới } & Nam & $46(30,7 \%)$ & $31(28,2 \%)$ & $15(37,5 \%)$ & 0,026 \\
\hline & Nữ & $104(69,3 \%)$ & $79(71,8 \%)$ & $25(62,5 \%)$ & $<0,001$ \\
\hline \multicolumn{2}{|c|}{ Tuối trung bình (năm) } & $50 \pm 15$ & $47 \pm 14$ & $59 \pm 12$ & $<0,001$ \\
\hline \multicolumn{2}{|c|}{ Tân số tim lúc nghỉ } & $77,4 \pm 11,8$ & $77,2 \pm 11,67$ & $78,03 \pm 12,24$ & 0,706 \\
\hline
\end{tabular}




\begin{tabular}{|c|c|c|c|c|c|}
\hline \multicolumn{2}{|c|}{ Huyết áp tâm thu } & $129,37 \pm 15,4$ & $126,1 \pm 14,3$ & $137,9 \pm 15,1$ & $<0,001$ \\
\hline \multicolumn{2}{|c|}{ Huyết áp tâm trương } & $76 \pm 9,3$ & $74,87 \pm 9,2$ & $79,13 \pm 9,1$ & 0,013 \\
\hline \multirow{3}{*}{$\begin{array}{c}\text { Triệu } \\
\text { chứng lâm } \\
\text { sàng }\end{array}$} & Trống ngực & $108(72 \%)$ & $81(73,6 \%)$ & $27(67,5 \%)$ & 0,538 \\
\hline & Tức ngực & $58(38,7 \%)$ & $41(37,3 \%)$ & $17(42,5 \%)$ & 0,561 \\
\hline & Mệt thiu & $27(18 \%)$ & $20(18,2 \%)$ & $7(17,5 \%)$ & 0,903 \\
\hline \multicolumn{2}{|c|}{ EF (\%) } & $61,25 \pm 5,9$ & $60,95 \pm 6,1$ & $62,05 \pm 5,4$ & 0,320 \\
\hline \multirow{2}{*}{\multicolumn{2}{|c|}{$\frac{\text { EAT (ms) }}{\text { Số lần triêt đốt (lần) }}$}} & $28,1 \pm 5,5$ & $28 \pm 5,1$ & $28,5 \pm 6,4$ & 0,605 \\
\hline \multirow{2}{*}{\multicolumn{2}{|c|}{$\begin{array}{l}\text { Số lần triệt đốt (lần) } \\
\text { Thời gian đốt (phút) }\end{array}$}} & $8,3 \pm 5,2$ & $8,5 \pm 5,3$ & $7,7 \pm 5,1$ & 0,400 \\
\hline & & $8,67 \pm 5,03$ & $9,19 \pm 5,26$ & $7,24 \pm 4,1$ & 0,036 \\
\hline
\end{tabular}

3.1.2. Đặc điếm điện tâm đồ bề mặt:

Bảng 3.2: Đặc điểm điện tâm đồ bề măt: thời gian, biên độ sóng của NTTT giứa 2 nhóm ĐRTP và ĐRTT ở các chuyển đạo trườc tim.

\begin{tabular}{|c|c|c|c|c|}
\hline Thông số & $\begin{array}{c}\text { Chung } 2 \text { nhóm } \\
\mathrm{N}=150\end{array}$ & $\begin{array}{c}\text { DRTP } \\
n=110\end{array}$ & $\begin{array}{l}\text { ĐRTT } \\
n=40\end{array}$ & $\begin{array}{c}\text { P } \\
\text { Value }\end{array}$ \\
\hline Khoảng ghép N & $\begin{array}{c}500,26 \pm 81,8 \\
(345-634)\end{array}$ & 3 & 5 & 0 \\
\hline Thời gian QRS (ms) & $128,8 \pm 28,8$ & $126 \pm 22,3$ & $136,5 \pm 32,9$ & 0,067 \\
\hline QRS dương & $150(100 \%)$ & & & \\
\hline Tỷ lệ thời gian só & $29,56 \pm 11,09$ & $30,15 \pm 10,92$ & $7,92 \pm 11,51$ & 0,277 \\
\hline Tý lệ thời gian sóng R V2 (\%) & $31,43 \pm 11,75$ & $30,55 \pm 10,51$ & $33,85 \pm 14,50$ & 0,192 \\
\hline Chỉ số thời gian sóng R (\%) & $35,29 \pm 11,65$ & $34,51 \pm 10,22$ & $37,42 \pm 14,84$ & 0,257 \\
\hline V1 (\%) &, 70 & $16,99=$ & $27,53 \pm 20,16$ & 0,002 \\
\hline Tý lệ biêt & $17,40 \pm 15,58$ & $14,52 \pm 14,21$ & $25,32 \pm 16,61$ & $<0,001$ \\
\hline Chỉ số biên độ R/S (\%) & $23,98 \pm 20,34$ & $20,60 \pm 18,91$ & $33,94 \pm 21,03$ & $<0,001$ \\
\hline Tỷ số chuyến tiếp V2 & $0,62 \pm 0,62$ & $0,51 \pm 0$ & $0,92 \pm 0,83$ & 0,005 \\
\hline Tỷ số & & $5 \pm$ & $1,99 \pm 1,06$ & $<0,001$ \\
\hline $2 / \mathrm{RV} 3$ & $4,78 \pm 5,83$ & $6,07 \pm 6,32$ & $1,23 \pm 0,78$ & $<0,001$ \\
\hline
\end{tabular}

3.2. Vai trò của tỷ lệ SV2/RV3 trong chẩn đoán phân biệt ngoại tâm thu thất có nguồn gốc đường ra thất phải (ĐRTP) và đường ra thất trái (ĐRTT).

3.2.1. Đặc điểm của tỷ lệ SV2/RV3 với hai nhóm ĐRTT và ĐRTP.

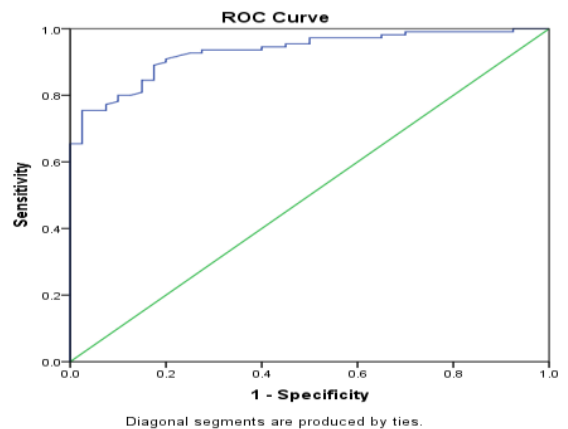

Biểu đồ 3.1: Giá trị chẩn đoán của chi số tỷ lệ SV2/RV3 ở nhóm nghiên cứu

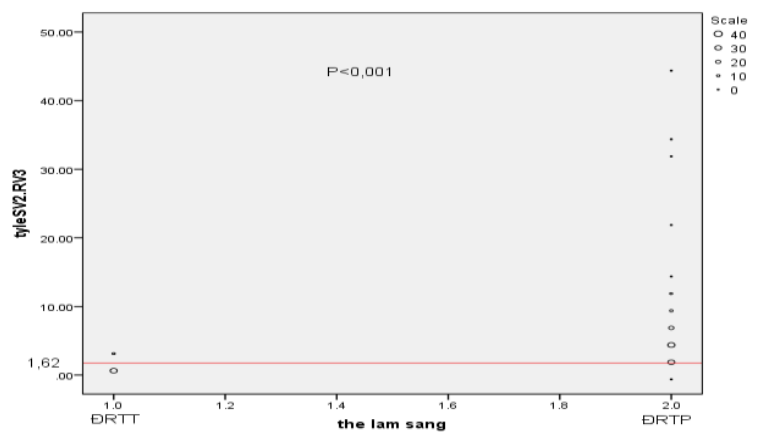

Biêu đồ 3.2: Giá trị cut-off của tỷ lệ SV2/RV3 là 1,6, có ý nghĩa phân biệt ngoại tâm thất đường ra với $p<0,001$.

3.2.2. So sánh trị chẩn đoán của tỷ lệ $\mathrm{SV} 2 / \mathrm{RV} 3$ với 1 số tiêu chuẩn trên nhóm nghiên cứu $(\mathrm{n}=150)$

Bảng 3.3: So sánh giá trị chẩn đoán của các tiêu chuẩn trên những bệnh nhân trong nhóm nghiên cứu nói chung

\begin{tabular}{|c|c|c|c|c|c|}
\hline Tiêu chuấn & Đố nhay \% & Đô đă̆c hiêuu \% & PPV \% & NPV \% & AUC (95\% CI) \\
\hline Tỷ lệ SV2/RV3 $\leq 1,6$ & 90,9 & 80 & 92,6 & 76,2 & $0,931(0,892-0,970)$ \\
\hline $\begin{array}{c}\text { Chỉ số thời gian sóng } \\
R \geq 50 \%\end{array}$ & 89 & 65 & 53 & 79 & $\begin{array}{c}0,522 \\
(0,402-0,642)\end{array}$ \\
\hline $\begin{array}{c}\text { Chỉ số biên độ R/S } \\
\geq 30 \%\end{array}$ & 84,4 & 52,5 & 52,8 & 81,6 & $\begin{array}{c}0,760 \\
(0,679-0,840)\end{array}$ \\
\hline
\end{tabular}




\begin{tabular}{|c|c|c|c|c|c|}
\hline $\begin{array}{c}\text { Tỷ số chuyến tiếp } \\
\text { tại V2 } \geq 0.6\end{array}$ & 74,5 & 50 & 58,3 & 80,4 & $\begin{array}{c}0,688 \\
(0,592-0,783)\end{array}$ \\
\hline TZ index $<0$ & 80 & 55 & 50 & 83 & $0,749(0,658-0,839)$ \\
\hline
\end{tabular}

\section{BÀN LUÂN}

4.1 Đặc điểm của đối tượng nghiên cứu:

Tất cả các bệnh nhân trong nhóm nghiên cứu đều có QRS của NTTT dương tại các chuyển đạo DII, DII, aVF, là đặc điểm của NTTT khởi phát từ vùng đường ra của tâm thất. Kết quả cho thấy giá trị của khoảng ghép trung bình là 500,26 \pm 81,8, giới hạn từ 345 -634 ms, không có sự khác biệt về giá trị khoảng ghép giữa 2 nhóm NTTT đường ra $(p=0,939)$. Theo y văn khoảng ghép của NTTT đơn ổ, vô căn thường hằng định và hiếm khi có hiện tượng $R / T$. Tỷ lệ biên độ $R / S$ ở nhóm $\mathrm{DRTT}$ tại $\mathrm{V} 1$ và $\mathrm{V} 2$ đều lớn hơn nhóm ĐRTP có ý nghĩa thống kê $(p=0,002$ và $p<$ $0,001)$, dần tới chỉ số biên độ $R / S$ (là tỷ lệ lớn hơn trong 2 tỷ lệ trên ở mối bệnh nhân) của ĐRTT cũng lớn hơn có ý nghĩa thống kê ( $p$ $<0,001$ ). Kết quả này phù hợp với các nghiên cứu trước kia của Ouyang (2002), Yoshida 2011, Phan Đình Phong (2014), Jiao (2016) ${ }^{3-6}$. Chỉ số chuyển tiếp tại V2 lẫn V3 của nhóm xoang Valsalva đều lớn hơn nhóm ĐRTP có ý nghĩa thống kê $(p=0,005$ và $p<0,001)$; trong khi đó nghiên cứu của Bentensky chỉ có sự khác biệt ở tỳ số chuyển tiếp tại V2 ${ }^{7}$.Chỉ số SV2/RV3 trong nghiên cứu của chúng tôi có giá trị trung bình ở nhóm ĐRTT thấp hơn có ý nghĩa thống kê so với nhóm ĐRTP $(p<0,001)$, tương tự kết quả nghiên cứu của Yoshida 20148. Tóm lại, hầu hết giá trị các chỉ số trên đều khác biệt có ý nghĩa thống kề giữa hai nhóm, cho thấy có cơ sở để sử dụng chúng trong định khu vị trí khởi phát NTTT. Đặc biệt chỉ số tỷ iệ SV2/RV3 nghiên cứu của chúng tôi khá dễ tính toán và ứng dụng trên lâm sàng.

3.3. Vai trò của tỷ lệ SV2/RV3 trong chẩn đoán ngoại tâm thu thất có nguồn gốc đường ra thất trái và đường ra thất phải.

Nghiên cứu trên 150 bệnh nhân NTTT có dạng block nhánh trái (40 bệnh nhân NTTT ổ khởi phát ĐRTT và 110 bệnh nhân ổ khởi phát ĐRTP), chúng tôi cho kết quả tỷ lệ SV2/RV3 có giá trị trung bình của nhóm ĐRTT nhỏ hơn nhóm ĐRTP có ý nghĩa thống kê $(1,23 \pm 0,78$ so với $6,07 \pm 6,32$ và $p<0,001)$. Điều này cũng phù hợp với nghiên cứu của Yoshida và cộng sự (2014) là trung bình của tỷ lệ SV2/RV3 ở nhóm ĐRTT là 0,8 so với nhóm ĐRTP là 4,1 có ý nghĩa thống kê $p<0,001^{8}$. Áp dụng thuật toán đường cong ROC để tính giá trị của tỷ lệ này với nhóm nghiên cứu của chúng tôi cho kết quả chỉ số
V2S/V3R có diện tích dưới đường cong là 0,931 (95\% CI: 0,892 - 0,970). Điểm cut-off tối ưu 1,612 , với chỉ số SV2/RV3 nhỏ hơn hoặc bằng giá trị này đạt độ nhạy và độ đặc hiệu lần lượt là $90,9 \%$ và $80 \%$ trong chẩn đoán NTTT từ ĐRTT. Kết quả của chúng tôi so với tác giả Yoshida và cộng sự cũng khá tương đồng (AUC: 0,964; cut-off tối ưu 1,5) ${ }^{8}$. Với nhóm bênh nhân có chuyển tiếp tại V3 $(n=64)$, kết quả của chúng tôi có diện tích dưới đường cong là 0,881 ( $95 \%$ CI: $0,795-0,968$ ), độ nhạy và độ đặc hiệu lần lượt là $79,3 \%$ và $88,6 \%$ cũng khá cao nhưng vấn thấp hơn của tác giả Yoshida $(n=77)$. Kết quả diện tích dưới đường cong trong nhóm này của ông là 0,898 với độ nhạy $94 \%$ và độ đặc hiệu là $78 \% 8$.

\section{KẾT LUÂ̂N}

Tiêu chuẩn tỷ lệ SV2/RV3 trong nghiên cứu của chúng tôi rất có giá trị chẩn đoán phân biệt NTTT từ ĐRTT và ĐRTP, với giá tri diên tích dưới đường cong là cao nhất $(A \cup C=0,931)$ so với các chỉ số trước đó. Đồng thời chúng tôi cũng nhận thấy chỉ số SV2/RV3 tương đối dễ tính toán và dễ ứng dụng trên lâm sàng với điện tâm đồ 12 chuyển đạo thường quy.

\section{TÀI LIÊU THAM KHẢO}

1. Hiss RG, Lamb LE. Electrocardiographic findings in 122,043 individuals. Circulation. 1962;25:947961. doi:10.1161/01.cir.25.6.947

2. Tanner $H$, Hindricks $G$, Schirdewahn $P$, et al. Outflow tract tachycardia with R/S transition in lead V3: six different anatomic approaches for successful ablation. J Am Coll Cardiol. 2005;45(3):418-423. doi:10.1016/j.jacc.2004.10.037

3. Vai trò của điện tâm đồ bề măt trong chẩn đoán phân biệt rối loạn nhịp thất khởi phát từ xoang valsalva với khởi phát tữ đường ra thất phải. https://www.facebook.com/V ien.Tim.mach.Viet. Nam/?ref=aymt homepage_panel. Accessed September 6, 2021. http://vientimmach.vn/vi/chi-dao-tuyen-va-bv-vetinh/vai-tro-cua-dien-tam-do-be-mat-trong-chandoan-phan-biet-roi-loan-nhip-that-khoi-phat-tuxoang-valsalva-voi-khoi-phat-tu-duong-ra-that phai.html

4. Ouyang F, Fotuhi $\mathbf{P}$, Ho SY, et al. Repetitive monomorphic ventricular tachycardia originating from the aortic sinus cusp: electrocardiographic characterization for quiding catheter ablation. J Am Coll Cardiol. 2002;39(3):500-508. doi:10.1016/ s0735-1097(01)01767-3

5. Jiao ZY, Li YB, Mao J, et al. Differentiating origins of outflow tract ventricular arrhythmias: a comparison of three different electrocardiographic 
algorithms. Braz J Med Biol Res. 2016;49. doi:10.1590/1414-431X20165206

6. Yoshida $\mathbf{N}$, Inden $\mathbf{Y}$, Uchikawa $T$, et al. Novel transitional zone index allows more accurate differentiation between idiopathic right ventricular outflow tract and aortic sinus cusp ventricular arrhythmias. Heart Rhythm. 2011;8(3):349-356. doi:10.1016/j.hrthm.2010.11.023

7. Betensky BP, Park RE, Marchlinski FE, et al. The V(2) transition ratio: a new electrocardiographic criterion for distinguishing left from right ventricular outflow tract tachycardia origin. J Am Coll Cardiol. 2011;57(22):2255-2262. doi:10.1016/j.jacc.2011.01.035

8. Yoshida N, Yamada T, Mcelderry HT, et al. A Novel Electrocardiographic Criterion for Differentiating a Left from Right Ventricular Outflow Tract Tachycardia Origin: The V2S/V3R Index: V2S/V3R Index Distinguishes LVOT from RVOT Origins. Journal of Cardiovascular Electrophysiology. doi:10.1111/jce.12392

\section{NHẬN XÉT ĐIỀU TRỊ NANG VÀ ÁP-XE TUYẾN BARTHOLIN TẠI BỆNH VIỆN PHỤ SẢN TRUNG ƯƠNG}

\section{TÓM TẮT}

Mục tiêu: Nhân xét một số đặc điểm về lâm sàng, cận lầm sàng; kết quả điều trịbệnh lý nang và áp-xe tuyến Bartholin tại Bệnh viện phụ sản Trung ương (BVPSTƯ). Phương pháp nghiên cứu: mô tả tiến cứu. Kết quả: Tuối trung bình của phụ nữ có bệnh lý tuyến Bartholin là $37,2 \pm 1,1$ tuổi. Có triểu chứng "đau" trong 78,6\% các trường hợp. Tỷ lệ thủ thuật "bóc tuyến" là $97,4 \%$ với điều trị nang tuyến Bartholin; trong điêu trị áp-xe tuyến Bartholin "chích khâu viền khăn" chiếm 90,3\%, "rach thoát dich" 9,7\%. Về kết quả điều trị: thủ thuật "chích khâu viên khăn" tái phát $20 \%$, di chứng seo cứng 16,7\%; "rạch thoát dịch" tái phát 33,3\%, di chứng sẹo cứng 33,3\%; "bóc tuyến" tái phát $5,3 \%$, di chứng seo cứng $5,3 \%$, đau khi giao hợp $2,6 \%$ và có tai biến chảy máu, tụ máu sau bóc là 5,2\%. Kết luận: phụ nữ mắc bệnh nang, áp-xe tuyến Bartholin chủ yếu trong độ tuổi sinh sản; "đau" là triệu chứng lâm sàng phố biến nhất trong bệnh lý tuyến Bartholin. Thủ thuật "bóc tuyến" chiếm tỷ lệ cao 97,4\% trong điều trị nang tuyến Bartholin; với tỷ lệ tái phát thấp $(5,3 \%)$ và ít di chứng. "Chích khâu viền khăn" chiếm tỷ lệ chủ yếu $(90,3 \%)$ trong điều trị ápxe tuyến Bartholin, với tỷ lệ tái phát và di chứngcao hơn nhiều so với bóc tuyến.

Tư khóa: nang tuyến Bartholin, áp-xe tuyến Bartholin.

\section{SUMMARY}

\section{COMMENTARY RESULTS TREATMENT OF BARTHOLIN GLAND CYSTS AND ABSCESSESAT THE NATIONAL HOSPITAL OF OBSTETRICS AND GYNECOLOGY}

Objectives: To review some clinical and subclinical characteristics and results in the treatment

\footnotetext{
${ }^{1}$ Bệnh viện đa khoa huyện Kim Sơn ${ }^{2}$ Đai hoc Y Hà Nôi

Chịu trách nhiệm chính: Nguyễn Bích Hồng

Email: nguyenbichhongnb@gmail.com

Ngày nhân bài: 3.8.2021

Ngày phản biên khoa hoc: 4.10 .2021

Ngày duyệt bài: 14.10.2021
}

\section{Nguyễn Bích Hồng ${ }^{1}$, Lê Thị Thanh Vân ${ }^{2}$}

of Bartholin gland cysts and abscesses at the National Hospital of Obstetrics and Gynecology. Methodology: Prospective descriptive. Results: The mean age of women with Bartholin gland disease was 37.2 \pm 1.1 years. There are symptoms of pain in $78.6 \%$ of cases. The rate of treatment technique, excision is $97.4 \%$ with Bartholin's cysts; in the treatment of Bartholin gland abscesses, marsupialization accounted for $90.3 \%$ and the procedure is $9.7 \%$. About the treatment results: the technique of marsupialization has a recurrence of $20 \%$, the sequelae of hard scars are $16.7 \%$; recurrence of the procedure is $33.3 \%$, sequelae of hard scars is $33.3 \%$; recurrence of excision is $5.3 \%$, sequelae of hard scarring $5.3 \%$, pain during intercourse $2.6 \%$ and there were bleeding complications, hematoma after peel was $5.2 \%$. Conclusion: women with Bartholin's gland disease are mainly of reproductive age; pain is the most common clinical symptom in Bartholin gland disease. The technique of excision accounts for a high rate of $97.4 \%$ in the treatment of Bartholin's cysts; with a low recurrence rate $(5.3 \%)$ and few sequelae. The technique of marsupialization accounts for $90.3 \%$ in the treatment of Bartholin gland abscess, with a higher rate of recurrence and sequelae than the excision technique.

Key words: Bartholin's gland cysts, bartholin's gland abscesses.

\section{I. ĐĂT VẤN ĐỀ}

Tuyến Bartholin là tuyến tiên đình lớn ở phụ nữ (giống như tuyến hành niệu đạo ở nam giới), gồm 2 tuyến nhỏ như hạt đậu ở hai bên âm hộ vị trí 4h-8h; có ống tuyến tiết dịch đổ vào âm đạo trong khi giao hợp. Bệnh lý tuyến Bartholin (chủ yếu là nang và áp-xe) khá phổ biến, $2 \%$ phụ nữ từng trải qua bệnh lý tuyến Bartholin trong cuộc đời họ ${ }^{1}$. Nang tuyến Bartholin do tắc và giãn ống. Sự tắc nghẽn có thể do nhiễm trùng hoặc không do nhiễm trùng; nhiễm trùng có thể tồn tại mạn tính và tái phát từng đợt. Áp-xe tuyến Bartholin có thể phát triển từ một ổ nhiễm 
trùng tiên phát hoặc thứ phát từ nang tuyến Bartholin. Nó liên quan đến phản ứng viêm cấp bao quanh ống và có mủ trong lòng áp-xe ${ }^{2}$. Hiện nay, có nhiêu thủ thuật điều trị nang và áp-xe tuyến Bartholin: rạch thoát dịch, chích khâu viền khăn, xơ hóa bằng cồn, loại bỏ tuyến bằng Nitrat bạc, đặt ống Word dẫn lưu, bóc tuyến... với tỷ lệ tái phát từ $2 \%$ đến $25 \%{ }^{1}$. Sự cải tiến kỹ thuật trong điều trị bệnh lý tuyến Bartholin nhằm giảm tái phát và di chứng, nâng cao chất lượng cuộc sống người phụ nữ sau phẫu thuật. Vì vậy, chúng tôi tiến hành nghiên cứu này, nhằm nhận xét điều trị của một số thủ thuật ngoại khoa, được áp dụng tại BVPSTU trên những bệnh nhân có nang, áp-xe tuyến Bartholin.

\section{II. ĐỐI TƯƠNGG VÀ PHƯƠNG PHÁP NGHIÊN CỨU \\ 2.1 Đối tượng nghiên cứu:}

- Tiêu chuẩn lựa chọn: Những bệnh nhân có bênhh lý tuyến Bartholin, điều trị tại bệnh viện BVPSTU từ tháng 9/2020 đến tháng 9/2021, thỏa mãn các tiêu chí: có đầy đủ các xét nghiệm cần thiết theo mẫu bệnh án nghiên cứu(công thức máu, sinh hóa máu, soi tươi dịch âm đạo); được chẩn đoán nang, áp-xe tuyến Bartholin và điều trị bằng các thủ thuật ngoại khoa.Bệnh nhân đồng ý tham gia nghiên cứu.

- Tiêu chuẩn loại trừ: bệnh nhân có bệnh lý tuyến Bartholin đang rong kinh, rong huyết; mắc các bệnh lý cấp tính đe dọa tính mạng (đột quy. não, suy gan cấp, hôn mê,...)

2.2 Phương pháp nghiên cứu: Nghiên cứu mô tả tiến cứu.

2.3 Cỡ mẫu nghiên cứu:

Bảng 2: Tỷ lệ triệu chứng lâm sàng, cận lâm sàng với mỗi hình thái tổn thương.

\begin{tabular}{|c|c|c|c|c|c|c|c|}
\hline & \multicolumn{6}{|c|}{ Triệu chứng lâm sàng, cận lâm sàng } & \multirow[b]{2}{*}{ Tổng } \\
\hline & $\begin{array}{l}\text { Có "sờ } \\
\text { thấy khối" }\end{array}$ & $\begin{array}{l}\text { Có "viêm } \\
\text { đỏ" }\end{array}$ & Có "đau" & $\begin{array}{l}\text { Có "rò } \\
\text { mủ" }\end{array}$ & Có "sốt" & $\begin{array}{l}\text { Có "băch } \\
\text { câu tăng" }\end{array}$ & \\
\hline $\mathbf{N}(\%)$ & $52(74,3 \%)$ & $34(48,6 \%)$ & $55(78,6 \%)$ & $5(7,1 \%)$ & $3(4,3 \%)$ & $25(35,7 \%)$ & $70(100 \%)$ \\
\hline $\begin{array}{c}\text { Nang tuyến } \\
\text { Bartholin N(\%) }\end{array}$ & $\begin{array}{c}35 \\
(92,1 \%)\end{array}$ & $\begin{array}{c}7 \\
(18,4 \%)\end{array}$ & $\begin{array}{c}24 \\
(63,2 \%)\end{array}$ & $\begin{array}{c}0 \\
(0 \%) \\
\end{array}$ & $\begin{array}{c}0 \\
(0 \%) \\
\end{array}$ & $\begin{array}{c}6 \\
(15,8 \%)\end{array}$ & $\begin{array}{c}38 \\
(100 \%) \\
\end{array}$ \\
\hline $\begin{array}{c}\text { Ap-xe tuyên Bartholin } \\
\mathrm{N}(\%)\end{array}$ & $\begin{array}{c}17 \\
(54,8 \%)\end{array}$ & $\begin{array}{c}26 \\
(83,9 \%)\end{array}$ & $\begin{array}{c}30 \\
(96,8 \%)\end{array}$ & $\begin{array}{c}5 \\
(16,1 \%)\end{array}$ & $\begin{array}{c}3 \\
(9,7 \%)\end{array}$ & $\begin{array}{c}19 \\
(61,3 \%)\end{array}$ & $\begin{array}{c}31 \\
(100 \%)\end{array}$ \\
\hline
\end{tabular}

Nhận xét: Triệu chứng "đau" chiếm tỷ lệ : 78,6\% trong tống số bệnh nhân, với những bệnh nhân áp-xe tuyến Bartholin, $96,8 \%$ có đau; $83,9 \%$ có viêm đỏ. Với nang tuyến Bartholin, triệu chứng "sờ thây khối" $92,1 \%$, triêuu chứng đau chiếm $63,2 \%$.

Bảng 3: Phân bồ kỹ thuật điều trị ngoại khoa theo chẩn đoán bệnh

\begin{tabular}{|c|c|c|c|c|c|}
\hline \multirow[b]{2}{*}{ Chẩn đoán } & \multicolumn{3}{|c|}{ Điều trị ngoại khoa } & \multirow[b]{2}{*}{ Tổng số } & \multirow{6}{*}{$P<0,05$} \\
\hline & $\begin{array}{l}\text { Chích khâu } \\
\text { viền khăn }\end{array}$ & Bóc tuyến & $\begin{array}{l}\text { Rạch thoát } \\
\text { dich }\end{array}$ & & \\
\hline Nang tuyến Bartholin & $1(2,6 \%)$ & $37(97,4 \%)$ & $0(0 \%)$ & $38(100 \%)$ & \\
\hline Áp-xe tuyến Bartholin & $28(90,3 \%)$ & $0(0 \%)$ & $3(9,7 \%)$ & $31(100 \%)$ & \\
\hline Nang+áp-xe tuyến Bartholin & $1(50 \%)$ & $1(50 \%)$ & $0(0 \%)$ & $2(100 \%)$ & \\
\hline Tổng số & $30(42,3 \%)$ & $38((53,5 \%)$ & $3(4,2 \%)$ & $71(100 \%)$ & \\
\hline
\end{tabular}


Nhận xét: Kỹ thuật "bóc tuyến" chiếm 97,4\% trong số 38 bệnh nhân nang tuyến Bartholin; "chích khâu viền khăn" chiếm 90,3\%, "rạch thoát dịch" chiếm 9,7\% trong số 31 bệnh nhân áp-xe tuyến Bartholin. Có 1 bệnh nhân được chẩn đoán nang và áp-xe tuyến Bartholin, được bóc tuyến và chích khâu viên khăn. $(p<0,05)$

Bảng 4: Tỷ lệ các tai biến trong bóc tuyến Bartholin.

\begin{tabular}{|c|c|c|}
\hline Tai biến & Số lượng (n) & Tỷ lệ (\%) \\
\hline Chảy máu sau mố & 1 & 2,6 \\
\hline Tụ máu sau mố & 1 & 2,6 \\
\hline Không tai biến & 36 & 94,8 \\
\hline Tống & 38 & 100 \\
\hline
\end{tabular}

Nhận xét: Trong 38 tốn thương được bóc tuyễn 2,6\% chảy máu sau mố; 2,6\% tụ máu sau mố. Còn lại 94,8\% các trường hợp không có tai biến.

\begin{tabular}{|c|c|c|c|c|c|c|c|}
\hline \multirow{2}{*}{$\begin{array}{c}\text { Điêuu trị } \\
\text { ngoại khoa }\end{array}$} & \multicolumn{2}{|c|}{ Tái phát } & \multicolumn{3}{|c|}{ Di chứng } & \multirow{2}{*}{$\begin{array}{l}\text { Tổng } \\
\text { Số }\end{array}$} & \multirow{6}{*}{$P<0,05$} \\
\hline & Không & Có & $\begin{array}{l}\text { Không di } \\
\text { chứng }\end{array}$ & $\begin{array}{l}\text { Seoo } \\
\text { cứng }\end{array}$ & $\begin{array}{l}\text { Đau khi } \\
\text { giao hơp }\end{array}$ & & \\
\hline $\begin{array}{l}\text { Chích khâu } \\
\text { viền khăn }\end{array}$ & $\begin{array}{c}24 \\
(80 \%) \\
\end{array}$ & $\begin{array}{c}6 \\
(20 \%) \\
\end{array}$ & $\begin{array}{c}25 \\
(83,3 \%) \\
\end{array}$ & $\begin{array}{c}5 \\
(16,7 \%) \\
\end{array}$ & $\begin{array}{c}0 \\
(0 \%) \\
\end{array}$ & $\begin{array}{c}30 \\
(100 \%)\end{array}$ & \\
\hline Bóc tuyến & $36(94,7 \%)$ & $2(5,3 \%)$ & $35(92,1 \%)$ & $2(5,3 \%)$ & $1(2,6 \%)$ & $38(100 \%)$ & \\
\hline $\begin{array}{l}\text { Rạch thoát } \\
\text { dịch }\end{array}$ & $\begin{array}{c}2 \\
(66,7 \%)\end{array}$ & $\begin{array}{c}1 \\
(33.3 \%)\end{array}$ & $\begin{array}{c}2 \\
(66,7 \%)\end{array}$ & $\begin{array}{c}1 \\
(33,3 \%)\end{array}$ & $\begin{array}{c}0 \\
(0 \%) \\
\end{array}$ & $\begin{array}{c}3 \\
(100 \%) \\
\end{array}$ & \\
\hline Tổng số & $\begin{array}{c}62 \\
(87,3 \%)\end{array}$ & $\begin{array}{c}9 \\
(12,7 \%)\end{array}$ & $\begin{array}{c}62 \\
(87,4 \%) \\
\end{array}$ & $\begin{array}{c}8 \\
(11,3 \%)\end{array}$ & $\begin{array}{c}1 \\
1,4 \%)\end{array}$ & $\begin{array}{c}71 \\
(100 \%) \\
\end{array}$ & \\
\hline
\end{tabular}

Nhân xét: Kỹ thuật "chích khâu viền khăn", tái phát $20 \%$, di chứng seo cứng $16,7 \%$. "Bóc tuyến", tái phát 5,3\%, di chứng đau khi giao hợp 2,6\%; sẹo cứng 5,3\%. "Rạch thoát dịch", tái phát $33,3 \%$, di chứng sẹo cứng $33,3 \%(p<0,05)$.

\section{BÀN LUẬN}

Trong nghiên cứu của chúng tôi, tuổi của bệnh nhân từ 15 đến 58 ; trung bình $37,2 \pm 1,1$ tuổi. Điều này tương tự nghiên cứu của Jin-Sung Yuk, với tuối trung bình là $38,1^{3}$. Ở bảng 1 , những bệnh nhân từ 20 đến 49 tuổi chiếm chủ yếu $84,3 \%$. Đây là độ tuổi sinh sản của phụ nữ, điều này cho thây: tổn thương nang, áp-xe tuyến Bartholin hay găp ở phụ nữ trong độ tuổi sinh sản. Sau 50 tuổi, tỷ lẹ mắc bệnh giảm, chỉ còn $11,4 \%$. Theo nghiên cứu của Jin-Sung Yuk, ở những phụ nữ trẻ tuổi, lượng dịch âm đạo và dịch tuyến Bartholin nhiều hơn so với phụ nữ sau tuổi mãn kinh. Nên nguy cơ bị lấp đầy bởi dịch, để tạo thành bệnh lý tuyến Bartholin ở người tré cao hơn phụ nữ sau mãn kinh. Ngoài ra, nồng độ hoocmon Estrogen giảm liên quan tới tuổi, cũng dẫn tới giảm tiết dịch và giảm bôi trơn các cơ quan sinh dục ngoài nên giảm nguy cơ mắc bệnh ${ }^{3}$.

Có triệu chứng "đau" chiếm tỷ lệ cao nhất $78,6 \%$ (bảng 2). Triệu chứng này cũng cao nhất trong những bệnh nhân áp-xe tuyến Bartholin; tiếp đến là có "viêm đỏ" 83,9\%; và "rò mủ" chỉ ởhình thái này. Theo GS Dương Thị Cương, dấu hiệu bắt đầu của áp-xe tuyến Bartholin là đau và nóng âm hộ một bên phía trước trên, ban đầu khu trú, sau lan tỏa. Bên trong đó chứa đầy mủ gây sưng dạng áp-xe ở đáy chậu, tầng sinh môn.
Nếu không can thiệp gì thì dẫn tới rò mủ, làm cho bệnh nhân nhẹ đi, nhưng dẫn lưu không đây đủ chính là nguồn gốc của tái phát sau này ${ }^{4}$. Trong số những bệnh nhân nang tuyến Bartholin, có triệu chứng "sờ thấy khối" chiếm tỷ lệ cao nhất 92,1\%. Nang tuyến Bartholin (đúng hơn là "nang ống tuyến Bartholin") do sự bít tắc ống dẫn của tuyến, làm dịch ứ lại, ống tuyến giãn ra hình thành khối nang. Nếu có nhiễm khuẩn, tạo thành áp-xe tuyến Bartholin². Vì vậy, các nang tuyến Bartholin trên lâm sàng khám chủ yếu dựa vào tính chất khối nang. Có triệu chứng sốt chiếm $9,7 \%$ trên tổng số bệnh nhân. Điều này tương tựnghiên cứu của H.Krissi, A.Shmuely (2015) với tỷ lệ trường hợp có sốt là $12,7 \%{ }^{5}$. Sở dĩ trong nghiên cứu của chúng tôi, tỷ lệ bệnh nhân có sốt thấp do ổ nhiễm khuẩn khu trú, ít khi ảnh hưởng tới toàn thân; và một số trường hợp sử dụng kháng sinh trước khi nhập viện. Còn tỷ lệ tăng bạch câu là 35,7\% trong tổng số bệnh nhân, chủ yếu tăng trong các trường hợp áp-xe $61,3 \%$, phản ánh tình trạng viêm tuyển Bartholin cấp tính. Phù hợp vớinghiên cứu của H.Krissi, A.Shmuely (2015), có 55,8\% các trường hợp áp-xe tuyến Bartholin bạch cầu tăng ${ }^{5}$.

Tại bệnh viện PSTÚ, áp dụng 3 thủ thuật điều trị cho các bệnh nhân nang, áp-xe tuyến Bartholin, bao gồm: chích khâu viền khăn, bóc 
tuyến, rạch thoát dịch. Có $97,4 \%$ bệnh nhân nang tuyến Bartholin được "bóc tuyến". Trong nghiên cứu của tác giả C. Cardaillac (2019) tại Pháp, điều trị nang tuyến Bartholin, tỷ lệ bóc tuyến là $69,3 \%{ }^{6}$. Có sự khác biệt lớn trong tỷ lệ "bóc tuyến" như vậy, vì nhiều quốc gia đề cao điều trị bảo tồn, chỉ bóc bỏ khi bệnh tái phát nhiều lần hoăc trong những trường hợp nghi ngờ ung thư tuyến Bartholin.Trong bảng 3, điều trị bệnh nhân áp-xe, thủ thuật "chích khâu viền khăn" chiếm 90,3\%; "rạch thoát dịch" 9,7\%. Tỷ lệ này tương đồng với nghiên cứu của $\mathrm{H}$. Krissi, A. Shmuely (2015) 80,9\%; đặt Word catheter $19,1 \%$ trong tổng số trường hợp. Các thủ thuật điêuu trị bệnh lý tuyến Bartholin không ngừng được cải tiến: đặt Word catheter, Jacob's ring, $\mathrm{CO}_{2}$ laser,... để đơn giản trong khâu vô cảm, có thể thực hiện ở phòng khám; tuy nhiên chỉ có $3 \%$ các bác sĩ biết đến và áp dụng các phương pháp điêu trị khác ngoài 3 thủ thuật trên tại cơ sở của hộ. Còn một lý do nữa để thủ thuật "bóc tuyến" hạn chế thực hiện, đó là những tai biến xảy ra trong quá trình bóc. Ởbảng 4, chúng tôi đã thống kê: "chảy máu sau mô" $(2,6 \%)$, và "tụ máu sau mô" $(2,6 \%)$, như vây tỳ lệ tai biến trong bóc tuyến là $5,2 \%$. Ớ một tổng quan hệ thống (2009), tụ máu và chảy máu trong bóc tuyến Bartholin từ $2 \%$ đến $8 \% 7$. Theo Giáo sư Dương Thị Cương (1996) sự bóc tách từ phía trong ra phía ngoài, từ chỗ ít mạch máu ra chỗ nhiêu mạch máu, nên đường rạch là trong niêm mạc âm đạo. Gặp những trường hợp viêm nhiễm rất khó tìm thấy bình diện bóc tách. Đặc biệt là phía trên, phía ngoài và phía trước có "cơ hành xốp" làm cho sự cầm máu khó khăn. Biến chứng của phẫu thuật này là tụ máu ở tầng sinh môn, đôi khi rất to ${ }^{4}$.

Bảng 5 chỉ ra, tỷ lê tái phát chung là 12,7\%; tái phát trong từng kỹ thuật: "rạch thoát dịch" $33,3 \%$, "chích khâu viền khắn" $20 \%$, "bóc tuyến" tái phát ít nhất $5,3 \%$. Những số liệu này, phù hợp nghiên cứu của Marzano (2004) ${ }^{1}$, tỳ lệ tái phát "chích khâu viên khăn" 2\%-25\%; Ellen Wechter (2009)7, tái phát "rạch thoát dịch" 0\%$38 \%$, bóc tuyến $0 \%-3 \%$. Đối với áp-xe tuyến Bartholin, việc bóc bỏ hoàn toàn tuyến là khó khăn do tình trạng viêm nhiễm lan tỏa, nên ở nghiên cứu của chúng tôi, tất cả bệnh nhân ápxe không có trường hợp nào được bóc tuyến. Khi điều trị áp-xe bằng các phương pháp bảo tồn tuyến, thì vẫn còn khả năng tái phát. Năm 2019, nghiên cứu hồi cứu 7 năm của tác giả Reut Rotem, chỉ ra: tìm thấy tỷ lê dương tính với vi khuẩn E.Coli cao hơn đáng kể ở những phụ nữ bị tái phát tổn thương tuyến Bartholin. Có thể, sự tái phát liên quan đến loại vi khuẩn ${ }^{8}$. Di chứng sẹo cứng sau"chích khâu viền khăn" là 16,7\%, sau "bóc tuyến" 5,3\%. Sở dĩ di chứng "sẹo cứng" chiếm phần lớn ở nhóm bệnh nhân được "chích khâu viền khăn", vì quy trình thực hiện thủ thuâat: khâu một vài mũi catgut 20 để giữa vỏ tuyến, da và niêm mạc tạo thành một túi thông ra ngoài. Chính những mũi khâu này làm cho quá trình tái tạo biểu mô, lành vết thương và hình thành sẹo cứng. Đối với bóc tuyến, việc lấy đi hoàn toàn tuyến làm mất chức năng tiết dịch trong quá trình giao hợp, nên chúng tôi đã ghi nhận 2,6\% bênh nhân "đau khi giao hợp" sau bóc. Một nghiên cứu thử nghiệm ngẫu nhiên: chức nằng tình dục sau điều trị áp-xe tuyến Bartholin, bằng 2 thủ thuật: bóc tuyến và chích khâu viền khăn. Tác giả dùng chỉ số chức năng tình dục ở người phụ nữ (FSFI) để đánh giá theo điểm. Theo đó, ở cả 2 thủ thuật thì FSFI đều thấp hơn mức bình thường; và thấp hơn ở nhóm "chích khâu viền khăn" (22,33 $\pm 5,11$ so với $24,76 \pm 4,32$ ở nhóm bóc tuyến). Và tác giả kết luận rằng bóc tuyến ít ảnh hưởng đến chức năng tình dục ở người phụ nữ hơn so với chích khâu viền khăn ${ }^{8}$.

\section{KẾT LUÂNN}

Bệnh lý nang, áp-xe tuyến Bartholin hầu hếtxảy ra trong độ tuổi sinh sản; "đau" là triệu chứng lâm sàng phổ biến nhất. Thủ thuật "bóc tuyến" chiếm tỷ lệ cao 97,4\% trong điều trị nang tuyến Bartholin; với tỷ lệ tái phát thấp $(5,3 \%)$ và di chứng đau khi giao hợp với tỷ lệ thấp 2,6\%. "Chích khâu viền khăn" chiếm tỷ lệ chủ yếu 90,3\% trong điều trị áp-xe tuyến Bartholin, với tỷ lệ tái phát cao $20 \%$ và di chứng nhiêu hơn so với thủ thuật bóc tuyến.

\section{TÀI LIÊU THAM KHẢO}

1. David A.Marzano, Hope K.Haefner. The Bartholin gland cyst: past, present, and future. Journal of Lower Genital Tract Disease. July 2004;8:195-204.

2. Purdir J, Auld BJ.A review of the management of diseases of the Bartholin' gland.Journal of Obstetrics and Gynaecology. Feb 2008;28(2):701-703.

3. Jin-Sung Yuk. Incedence of Bartholin duct cysts and abscesses in the Republic of Korea.International Journal of Gynecalogy and Obstetrics.2013;122:62-64.

4. Dương Thị Cương. Ba trường hợp điều trị u nang tuyến Bartholin bằng khâu lộn túi. Tạp chí y học thực hành. 1996; số 6.

5. Krissi H, Shmuely A. Acute Bartholin's abscess: microbial spectrum, patient characteristics, clinical manifestation, and surgical outcomes.Eur J Clin Microbiol Infect Di. 2015;35:443-446. 
6. Cardaillac, Claire. Surgical management of Bartholin cysts and abscesses in French university hospitals.Journal of gynecology obstetrics and human reproduction. 2019;48(8): 631-635.

7. Wechter ME. Management of Bartholin duct cysts and abscesses: a systematic review. Obstet
Gynecol Surv. 2009;64(6):395-404.

8. RotemR. Risk factors associated with recurrent referral to the emergency room following surgical treatment of Bartholin's gland abscess.Journal of Obstetrics and Gynaecology. 2020;40(1):111-115.

\title{
GIÁ TRỊ CỦA SIÊU ÂM KẾT HỢP ĐÀN HỒI MÔ TRONG CHẨN ĐOÁN UNG THƯ TUYẾN TIỀN LIỆT
}

\author{
Đoàn Thị Nga ${ }^{1}$, Nguyễn Lan Hương ${ }^{2}$, Nguyễn Duy Hùng ${ }^{1,2}$, \\ Lê Thanh Dũng ${ }^{2}$, Nguyễn Duy Huề
}

\section{TÓM TẮT}

Mục tiêu: đánh giá giá trị của siêu âm kết hợp đàn hồi mô trong chẩn đoán ung thư tuyến tiền liệt (UTTTL). Đối tượng và Phương pháp: 74 bệnh nhân nghi ngờ UTTTL được siêu âm qua đường trực tràng đa phương tiện gồm 2D, Doppler màu và $S E$, được đối chiếu với kết quả giải phâu bệnh qua sinh thiết hệ thống 12 mẫu dưới hướng dẫn siêu âm qua đường trực tràng tại bệnh viện Hữu nghị Việt Đức từ tháng $5 / 2020$ đến tháng $6 / 2021$. Kết quả: Nghiên cứu có $28 / 74$ bệnh nhân ung thư $(38 \%)$, phát hiện $78 / 296$ tổn thương ung thư ở 2 vùng chính là vùng ngoại vi (36) và vùng chuyển tiếp (42).Trong chẩn đoán UTTTL nằm ở vùng ngoại vi, siêu âm 2D, 2D+Doppler màu, 2D+Doppler màu+SE có độ nhay lần lượt là $72.2 \%, 72.2 \%, 80.6 \%$. Trong chẩn đoán UTTTL nằm ở vùng chuyển tiếp, siêu âm 2D, 2D+Doppler màu, 2D+Doppler màu+SE có độ nhạy lần lượt là 40.5\%, 66.7\%, 85.7\%. Kết luận: Siêu âm 2D qua đường trực tràng có độ nhạy cao trong chẩn đoán UTTTL nằm ở vùng ngoại vi nhứng có độ nhạy thấp trong chẩn đoán UTTTL nằm ở vùng chuyển tiếp. Kết hợp hai hoă̆c ba kĩ thuật siêu âm đều làm tăng độ nhay trong chẩn đoán UTTTL đặc biệt ở vùng chuyển tiếp.Siêu âm đàn hồi mô là phương pháp bố trợ giúp làm tăng đôn nhay trong chẩn đoán UTTTL.

Tư khóa: ung thư tuyến tiền liệt, siêu âm qua đường trực tràng, siêu âm kết hợp đàn hồi mô.

\section{SUMMARY}

\section{VALUES OF ULTRASOUND ASSOCIATED ELASTOGRAPHY IN THE DIAGNOSIS OF PROSTATE CANCER}

Purpose: This study aims to evaluate the value of ultrasound associated elastography in the diagnosis of prostate cancer. Material and Method: 74 patients with suspected prostate cancer was performed transrectal multiparametric ultrasound includes 2D,

\footnotetext{
${ }^{1}$ Trường đại học Y Hà Nội,

²Bệnh viện Hữu nghi Việt Đức

Chịu trách nhiệm chính: Đoàn Thị Nga

Email: Doannga0226@gmail.com

Ngày nhận bài: 4.8.2021

Ngày phản biện khoa học: 5.10.2021

Ngày duyệt bài: 14.10.2021
}

color Doppler and elastography, was compare with Histological results follow transrectal US guide system biopsy12 core at the Viet Duc Hospital from May 2020 to June 2021. Results: This study has $28 / 74$ patients with prostate cancer (38\%), detect 78/296 cancer lesions located in two main zones are peripheral zone (36) and transition zone (42). Diagnosis cancer in peripheral zone on 2D, 2D+color Doppler, 2D+color Doppler+SE has sensitivity of $72.2 \%, 72.2 \%, 80.6 \%$, respectively. Diagnosis cancer in transition zone on 2D, 2D+color Doppler, 2D+Doppler+SE has sensitivity of $40.5 \%, 66.7 \%, 85.7 \%$. Conclusion: Transrectal ultrasound $2 \mathrm{D}$ has high sensitivity in the diagnosis prostate cancer in the peripheral zone and low sensitivity in the diagnosis prostate cancer in the transition zone. To combine two or three technical ultrasound increase the sensitivity in diagnosis prostate cancer, especially in transition zone. Sonoelastography is supplement way to increase sensitivity in the diagnosis prostate .

Keywords: prostate cancer, transrectal ultrasound, ultrasound associated elastography.

\section{I. ĐẶT VẤN ĐỀ}

Ung thư tuyến tiên liệt (UTTTL) là loại ung thư thường gặp nhất và là nguyên nhân gây tử vong thứ tư do ung thư ở nam giới ${ }^{1}$. UTTTL có tỉ lệ sống sau 5 năm là $100 \%$ nếu được phát hiện sớm ở giai đoạn còn khu trú, tuy nhiên, ở giai đoạn đã có di căn, tỉ lệ này giảm xuống chỉ còn $32 \%$, do đó việc chẩn đoán sớm và điều trị kịp thời có vai trò rất quan trọng.

Siêu âm là phương pháp chẩn đoán cơ bản và đâuu tay trong chẩn đoán UTTTL nhưng hiện nay chưa có một kĩ thuật siêu âm riêng lẻ nào được coi là tối ưu, do vậy sinh thiết hệ thống dưới hướng dẫn của siêu âm qua đường trực tràng vẫn là phương pháp được lựa chọn để chẩn đoán xác định UTTTL ở những bệnh nhân có PSA> $4 \mathrm{ng} / \mathrm{ml}^{2}$. Siêu âm TTL qua đường trực tràng (TRUS) đã khắc phục được những nhược điểm của siêu âm qua đường bụng và là phương pháp chính trong phát hiện các tổn thương của TTL. TRUS bao gồm đồng thời siêu âm 2D và siêu âm Doppler, ngay nay còn được bổ sung thêm siêu 
âm đàn hồi mô (SE) đánh giá độ cứng của mô, được tích hợp trong cùng một đầu dò ${ }^{3}$.

Các mô bệnh lý có thể có cùng độ hồi âm nhưng chúng có độ cứng khác nhau, mồ càng ác tính thì độ cứng càng tăng. Siêu âm 2D không phát hiện được những tổn thương ung thư đồng âm. Nhiêu trường hợp tổn thương ung thư không tăng sinh mạch, vì vậy siêu âm Doppler vẫn khó nhận định tính chất lành tính hay ác tính ${ }^{4}$. Siêu âm đàn hồi mô đánh giá được độ cứng của mô tổn thương từ đó cung cấp thêm thông tin cho siêu âm $2 \mathrm{D}$ và Doppler trong chẩn đoán UTTTL ${ }^{5}$.

Cho đến nay, trên thế giới đã có nhiều nghiên cứu về ứng dụng của siêu âm kết hợp đàn hồi mô trong đánh giá các tổn thương khu trú tại $T T L$, cụ thể là khả năng phân biệt tổn thương lành tính hay ác tính. Tuy nhiên tại Việt Nam, kĩ thuật siêu âm đàn hồi vẫn chưa được ứng dụng rộng rãi và có rất ít nghiên cứu đề cập đến giá trị của siêu âm đàn hồi trong chẩn đoán UTTTL. Vì vậy chúng tôi tiến hành nghiên cứu này nhằm đánh giá giá trị của siêu âm kết hợp đàn hồi mô trong chẩn đoán UTTTL.

\section{II. ĐỐI TƯợNG VÀ PHƯƠNG PHÁP NGHIÊN CỨU}

Đối tượng nghiên cứu. Nghiên cứu được tiến hành trên 74 bệnh nhân được nghi ngờ UTTTL (thăm trực tràng nghi ngờ hoặc xét nghiêm $\mathrm{PSA}>4 \mathrm{ng} / \mathrm{ml}$ hoặc bằng các phương pháp CĐHA như siêu âm qua đường bụng, cộng hưởng từ), được siêu âm qua đường trực tràng kết hợp đàn hồi mô, được sinh thiết 12 mẫu và có kêt quả giải phẫu bệnh.

Kĩ thuật siêu âm. Thăm khám được thực hiện trên máy siêu âm LOGIQ S7 Expert với đầu dò trực tràng hai bình diện BE9CS có tần số từ 8 đến $10 \mathrm{MHz}$ và có kênh sinh thiết tích hợp đồng bộ.Bệnh nhân được giải thích quy trình, đi tiểu trước khi thực hiện siêu âm. Tư thế bệnh nhân: nằm nghiêng trái, hai chân co tạo góc giữa đùi và bụng nhỏ hơn hoặc bằng 90 độ. Khảo sát TTL một cách toàn diện trên các lớp cắt dọc và cắt ngang theo trình tự từ đỉnh đến đáy $T L$ và từ phải sang trái. Khảo sát tuần tự từ hình thái, huyết động đến tính chất vật lý: siêu âm 2D, siêu âm Doppler màu, siêu ẩm đàn hồi. Trong thu hình siêu âm đàn hồi, ROI cần được bao phủ toàn bộ tuyến và mô xung quanh nhưng không bao gồm bàng quang để tránh ảnh giả. Thực hiện ép đầu dò với lực thật nhe (mức dịch chuyển đâu dò khoảng $1 \%$ độ sâu của vùng mô chứa $T T L$ ) rồi nhả ép, thực hiện trên cùng mặt phẳng cắt. Ghi nhận hình ảnh sau khi nhả ép rồi lặp lại cho đến khi thu chọn được hình với chỉ điểm chất lượng đạt. Sau khi thu được một seri ảnh đàn hồi, sẽ chọn hình tối ưu là hình có yếu tố chất lượng (quality factor) cao nhất ${ }^{6}$. Toàn bộ dữ liệu ảnh và video đều được lưu trữ trên máy siêu âm.

Phân tích hình ảnh. Tiêu chuẩn chẩn đoán UTTTL trên siêu âm 2D gồm một trong các dấu hiệu sau: (1)Vùng ngoại vi: vùng có độ hồi âm thay đổi so với nhu mổ xung quanh \pm phá võ vỏ tuyến \pm xâm lấn nhu mô xung quanh \pm bờ tuyến không đều \pm tuyến mất cân đối, (2)vùng chuyển tiếp: vùng có độ hồi âm thay đổi so với nhu mô xung quanh và đẩy lồi về phía ngoại vi \pm bờ tuyến không đều \pm tuyến mất cân đối ${ }^{3}$.

Tiêu chuẩn chẩn đoán UTTTL trên siêu âm Doppler màu gồm một trong các dấu hiệu sau: tăng tín hiệu dòng chảy khu trú, tín hiệu dòng chảy không đối xứng tại mô ung thư cùng với tăng số lượng và kích thước mạch máu ${ }^{3}$.

Tiêu chuẩn chẩn đoán UTTTL trên siêu âm đàn hồi: phân tích hình ảnh trên bản đồ màu,sử dụng 5 thang điểm của Kamoi dựa vào mức độ và sự phân bố tính đàn hồi của mô tương quan với tổn thương giảm âm trên 2D. Hệ thống phân loại này mã hóa mô cứng là màu xanh dương và mô mềm là màu đỏ hoặc xanh lá.Score 1: bình thường (mật độ đồng nhất). Score 2: khả năng bình thường (mật độ không đồng nhất dạng khảm). Score 3: khổng xác định (ổ cứng - màu xanh không đối xứng và khồng liên quan với có một tổn thương giảm âm). Score 4: khả năng ác tính: có tổn thương giảm âm với cứng (màu xanh ở trung tâm và còn mềm ở ngoại vi). Score 5 : chắc chắn ác tính: có tổn thưởng giảm âm với cứng toàn bộ và cả tổ chức xung quanh. UTTTL được nghi ngờ khi mô tổn thương có score từ 3 trở lên ${ }^{7}$.

Tiêu chuẩn chẩn đoán UTTTL khi kết hợp 2 hoặc 3 kĩ thuâtt 2D, Doppler màu, đàn hồi: khi có ít nhất một tiểu chuẩn chẩn đoán UTTTL của một kĩ thuật siêu âm.

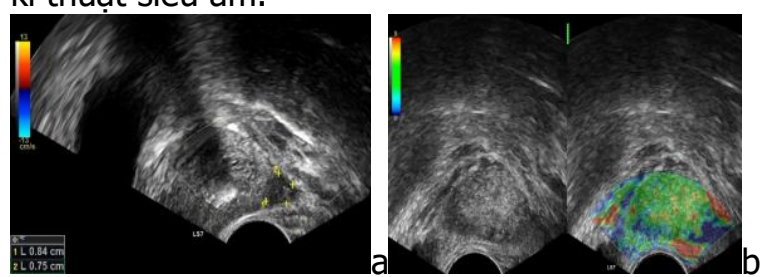

Hình 1: Bệnh nhân P.H.T 65 tuổi, PSA $7.89 \mathrm{ng} / \mathrm{ml}$, (a) tổn thương giảm âm vùng ngoại vi trái không tăng sinh mạch trên siêu âm $2 \mathrm{D}$ và Doppler màu, (b) tổn thương tương ứng $\mathrm{SE}$ score 4 trên siêu âm đàn hồi (trung tâm màu xanh dương biểu hiện cứng, ngoại vi màu xanh 
lá biểu hiện mềm), gleason 4+4=8.

Xử lý và phân tích số liệu. Số liệu được nhập và phân tích bằng phần mềm SPSS 20.0 (SPSS, Inc., Chicago, Hoa Kỳ). Các biến được trình bày dưới dạng số và tỷ lệ phần trăm.

Giá trị của siêu âm 2D, Doppler, đàn hồi và kết hợp ba phương pháp trong chẩn đoán xác định UTTTL được xác định bằng độ nhạy, độ đặc hiệu, giá trị dự đoán dương tính, giá trị dự đoán âm tính và độ chính xác với kết quả giải phẫu bệnh là tiêu chuẩn vàng.

\section{KẾT QUẢ NGHIÊN CỨU}

Từ tháng $5 / 2020$ đến tháng 6/2021, 74 bệnh nhân được nghi ngờ UTTTL (từ 55 đến 89 , độ tuổi trung bình là $67.22 \pm 6.96$, PSA toàn phần trung bình là $31.57 \pm 27.2 \mathrm{ng} / \mathrm{ml}$, thể tích $T \mathrm{TL}$ trung bình là $54.78 \pm 26.38 \mathrm{ml}$ ) được siêu âm qua đường trực tràng kết hợp đàn hồi mô và được sinh thiết 12 mẩu tại khoa Chẩn đoán hình ảnh của bệnh viện Hữu nghị Việt Đức.

Mỗi bệnh nhân được sinh thiết 12 mẫu và chia thành 4 vùng tổn thương tương ứng với vùng ngoại vi phải (mảnh số $1,2,3$ ), vùng chuyển tiếp phải (mảnh số 4,5,6), vùng chuyển tiếp trái (mảnh số $7,8,9)$, vùng ngoai vi trái (mảnh số 10 , $11,12)$. Mỗi vùng được đánh giá lần lượt trên siêu âm 2D, Doppler màu và $\mathrm{SE}$. Dựa vào tiêu chuẩn chẩn đoán UTTTL của mỗi kĩ thuật siêu âm đã nêu trên, mỗi vùng được ghi nhận là có hay không có tổn thương nghi ngờ ung thư đối với mỗi kĩ thuật siêu âm.

Phân tích 296 vùng có tất cả 78 tổn thương ung thư được xác định bằng giải phẫu bệnh, trong đó có 36 tổn thương ở vùng ngoại vi và 42 tổn thương ở vùng chuyển tiếp.

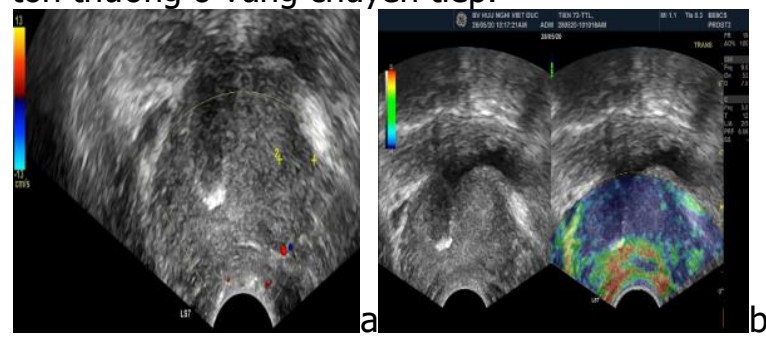

Hình 2: Bệnh nhân H.M.T 72 tuổi, PSA $64.3 \mathrm{ng} / \mathrm{ml}$, (a) tổn thương giảm âm không đồng nhất vùng chuyển tiếp trái, không tăng sinh mạch trên siêu âm Doppler, tổn thương tương ứng SE score 4 trên siêu âm đàn hồi (trung tâm màu xanh dương biểu hiện cứng, ngoại vi màu xanh lá biểu hiện mềm), gleason $4+3=7$.

Bảng 1 thể hiện giá trị của siêu âm 2D, 2D kết hợp Doppler màu và kết hợp 3 kĩ thuật trong chẩn đoán UTTTL ở vùng ngoại vi. Siêu ầm 2D có độ nhạy $72.2 \%$, độ đặc hiệu $67 \%$. Siêu âm 2D kết hợp Doppler màu có độ nhạy không đổi, độ đặc hiệu $66.1 \%$. Kết hợp cả ba kĩ thuậtlàm tăng độ nhạy và độ đặc hiệu lần lượt là $80.6 \%$ và $64.3 \%$.

Bảng 1: Giá trị của siêu âm 2D, 2D+Doppler màu, 2D+Doppler màu+SE trong chẩn đoán UTTTL ở vùng ngoại vi ( $n=148)$

\begin{tabular}{|c|c|c|c|c|c|}
\hline Kỹ thuật siêu âm & $\begin{array}{c}\text { Độ nhạy } \\
\mathbf{( \% )}\end{array}$ & $\begin{array}{c}\text { Độ đặc } \\
\text { hiệu (\%) }\end{array}$ & $\begin{array}{c}\text { Giá trị dự } \\
\text { đoán dương } \\
\text { tính (\%) }\end{array}$ & $\begin{array}{c}\text { Giá trị dự } \\
\text { đoán âm } \\
\text { tính (\%) }\end{array}$ & $\begin{array}{c}\text { Độ chính } \\
\text { xác (\%) }\end{array}$ \\
\hline 2D & 72.2 & 67 & 41.3 & 88.2 & 68.2 \\
\hline 2D+Doppler màu & 72.2 & 66.1 & 40.6 & 88.1 & 67.6 \\
\hline 2D+Doppler màu+SE & 80.6 & 64.3 & 42 & 91.1 & 90.1 \\
\hline
\end{tabular}

Bảng 2 thể hiện giá trị của siêu âm 2D, 2D kết hợp Doppler màuvà kết hợp cả ba kĩ thuật trong chẩn đoán UTTTL ở vùng chuyển tiếp. Siêu âm $2 \mathrm{D}$ có độ nhạy $40.5 \%$, độ đặc hiệu $88.7 \%$. Siêu âm 2D kết hợp Doppler màu có độ nhạy $66.7 \%$, độ đặc hiệu 59.4\%. Kết hợp cả ba kĩ thuật có độ nhạy $85.7 \%$, độ đặc hiệu $59.4 \%$.

Bảng 2: Giá trị của siêu âm 2D, 2D+Doppler màu, 2D+Doppler màu+SE trong chẩn đoán UTTTL ở vùng chuyển tiếp ( $n=148)$

\begin{tabular}{|c|c|c|c|c|c|}
\hline Kỹ thuật siêu âm & $\begin{array}{c}\text { Độ nhạy } \\
(\mathbf{\%})\end{array}$ & $\begin{array}{c}\text { Độ đặc } \\
\text { hiệu } \\
\mathbf{( \% )}\end{array}$ & $\begin{array}{c}\text { Giá trị dự } \\
\text { đoán dương } \\
\text { tính (\%) }\end{array}$ & $\begin{array}{c}\text { Giá trị dự } \\
\text { đoán âm } \\
\text { tính (\%) }\end{array}$ & $\begin{array}{c}\text { Độ chính } \\
\text { xác (\%) }\end{array}$ \\
\hline 2D & 40.5 & 88.7 & 58.6 & 79 & 75 \\
\hline 2D+Doppler màu & 66.7 & 59.4 & 39.4 & 81.8 & 61.5 \\
\hline 2D+Doppler màu+SE & 85.7 & 59.4 & 45.6 & 91.3 & 66.9 \\
\hline
\end{tabular}

Bảng 3 thể hiện giá trị của siêu âm 2D, 2D+Doppler màuvà kết hợp ba kĩ thuật trong chấn đoán UTTTL ở cả hai vùng. Siêu âm $2 \mathrm{D}$ có độ nhạy $55.1 \%$, độ đặc hiệu $77.5 \%$. Siểu âm $2 \mathrm{D}$ kết hợp Doppler màu có độ nhạy $69.2 \%$, độ đặc hiệu $62.8 \%$. Kết hợp ba kĩ thuật có độ nhạy $83.3 \%$, độ đặc hiệu $61.9 \%$. 
Bảng 3: Giá trị của siêu âm 2D, 2D+Doppler màu, 2D+Doppler màu+SE trong chẩn đoán UTTTL ở cả hai vùng ( $n=296)$

\begin{tabular}{|c|c|c|c|c|c|}
\hline Kỹ thuật siêu âm & $\begin{array}{c}\text { Độ nhạy } \\
(\mathbf{\%})\end{array}$ & $\begin{array}{c}\text { Độ đặc } \\
\text { hiệu (\%) }\end{array}$ & $\begin{array}{c}\text { Giá trị dư đoán } \\
\text { dướng tính } \\
(\mathbf{\%})\end{array}$ & $\begin{array}{c}\text { Giá trị dự } \\
\text { đoán âm } \\
\text { tính (\%) }\end{array}$ & $\begin{array}{c}\text { Độ chính } \\
\text { xác (\%) }\end{array}$ \\
\hline 2D & 55.1 & 77.5 & 46.7 & 82.8 & 71.6 \\
\hline 2D+Doppler màu & 69.2 & 62.8 & 40 & 85.1 & 64.5 \\
\hline 2D+Doppler màu+SE & 83.3 & 61.9 & 43.9 & 91.2 & 67.6 \\
\hline
\end{tabular}

\section{BÀN LUÂNN}

Phần lớn UTTTL có xu hướng tiển triển chậm, mức độ thấp và không quá ác tính. Tổn thương có thể phát triển ra ngoài bao tuyến hoặc khu trú trong tuyến qua nhiều thập $\mathrm{Ki}^{1}$. UTTTL chủ yếu nằm ở vùng ngoại vi $(70 \%)$ thuận lợi cho siêu âm qua đường trực tràng dể tiếp cận tổn thương ${ }^{3}$.

Trong nghiên cứu của chúng tôi, tỷ lệ ung thư chiếm 38\% (28/74), UTTTL thường gặp ở độ tuổi từ 55 đến 77 , thể tích TTL và PSA toàn phần trung bình trong nhóm ung thư lần lượt là 45.9 $\pm 24.7 \mathrm{ml}$ và $38.6 \pm 36 \mathrm{ng} / \mathrm{ml}$. Độ tuổi và tỷ lê ung thư trong mẫu nghiên cứu gẩn tương đồng với kết quả của Giurgiü. Thể tích TTL và PSA toàn phần trung bình của mẫu nghiên cứu cao hơn so với các nghiên cứu trước.

Nhu mô vùng ngoại vi bình thường có độ hồi âm đồng nhất và độ cứng trung gian do vậy một tổn thương ung thư nằm ở vùng ngoại vi có độ hồi âm thay đổi và có đô̂ cứng tăng sẽ dễ được phát hiện trên siêu âm. Ngược lại vùng chuyển tiếp vốn có độ hồi âm không đồng nhất trên siêu âm và có độ cứng tăng hơn nhất là ở người già khi có các nốt tăng sản, do vậy rất khó có thể phát hiện được các tổn thương khu trú tại vùng này ${ }^{3}$.

Trong nghiên cứu của chúng tôi, độ nhạy của siêu âm 2D, 2D+Doppler màu và 2D+Doppler màu+SE trong chẩn đoán UTTTL ở vùng ngoai vi lần lượt là $72.2 \%, 72.2 \%$ và $80.6 \%$; độ đặc hiệu lần lượt là $67 \%, 66.1 \%$ và $64.3 \%$. Như vậy khi kết hợp cả 3 kĩ thuật có làm tăng độ nhạy trong chẩn đoán UTTTL ở vùng ngoai vi. Theo nghiên cứu của Gadalla ${ }^{9}$ độ nhạy của SE trong chẩn đoán UTTTL ở vùng ngoại vi $100 \%$ và $60 \%$ tương ứng với vùng ngoại vi phải và trái. Nguyên nhân làm cho độ nhay của SE trong nghiên cứu của chúng tôi thấp hơn là do SE hạn chế trong việc phát hiện những tổn thương ung thư nhỏ và có điểm Gleason thấp ${ }^{5}$. Trong nghiên cứu của chúng tôi SE chỉ phát hiện được $2 / 5$ tổn thương có điểm Gleason 6 và 3/7 tổn thương có điểm Gleason 7.

Đối với những tổn thương ung thư ở vùng chuyển tiếp, độ nhạy của siêu âm $2 \mathrm{D}$ chỉ là $40.5 \%$ do đặc tính không đồng nhất vốn có của vùng chuyển tiếp. Thể tích TTL trung bình của mẫu nghiên cứu cao hơn so với các nghiên cứu trước nên đây cũng là nguyên nhân làm giảm độ nhay của siêu âm do vùng chuyển tiếp định vị ở phía trước tuyến nên khi thể tích TTL càng tăng thì khả năng khảo sát của sóng siêu âm càng

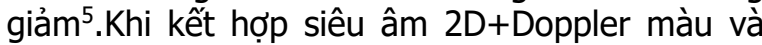
$2 \mathrm{D}+$ Doppler màu+SE có độ nhạy tăng lên lần lượt là $66.7 \%$ và $85.7 \%$ nhưng độ đặc hiệu giảm còn $59.4 \%$.

Khi đánh giá tổn thương trên cả hai vùng chuyển tiếp và ngoại vi, độ nhạy của siêu âm $2 \mathrm{D}$ chỉ $55.1 \%$ do trong mấu nghiền cứu của chúng tôi phần lớn tổn thương ung thư định vị ở vùng chuyển tiếp (42/78 tổn thương). Khi kết hợp hai và ba phương pháp độ nhạy tăng lên lần lượt là $69.2 \%$ và $83.3 \%$. Theo nghiên cứu của Giurgiu ${ }^{8}$, độ nhạy của siêu âm 2D, 2D+Doppler, 2D+Doppler+SE lần lượt là $67.05 \%, 78.57 \%$, $89.2 \%$; độ đặc hiêuu lần lượt là $51.4 \%, 27.02 \%$ và $24.32 \%$. Nghiển cứu của chúng tôi có độ nhạy thấp hơn nhưng độ đặc hiệu cao hơn so với nghiên cứu của Giurgiư ${ }^{8}$.

Hạn chế của nghiên cứu là do siêu âm đàn hồi mô sử dụng các thông số bán định lượng và là kĩ thuật phụ thuộc vào kinh nghiệm của người làm. Ngoài ra cấu tạo của đầu dò trực tràng có khoảng cách giữa hai bình diện rộng nên mặt phẳng tiếp cận với thành trực tràng không đều.

\section{KẾT LUẦN}

Qua nghiên cứu chúng tôi nhận thấy siêu âm đa phương tiện qua đường trực tràng gồm các kĩ thuật 2D, Doppler, SE có giá trị thay đổi khi đánh giá tổn thương nằm ở vùng ngoại vi hay chuyển tiếp. Siêu âm 2D qua đường trực tràng có độ nhạy cao trong chẩn đoán UTTTL nằm ở vùng ngoại vi nhưng có độ nhay thấp trong chẩn đoán UTTTL nằm ở vùng chuyển tiếp. Kết hợphai hoặc ba kĩ thuật siêu âm đều làm tăng độ nhạy trong chẩn đoán UTTTL đặc biệt ở vùng chuyển tiếp. Siêu âm đàn hồi mô được coi là phương pháp bồ trợ của siêu âm TTL qua đường trực tràng làm tăng độ nhạy chẩn đoán UTTTL.

\section{TÀI LIÊU THAM KHẢO}

1. Leslie SW, Soon-Sutton TL, Sajjad H, Siref LE. Prostate Cancer. In: StatPearls. StatPearls 
Publishing; 2021. Accessed September 26, 2021. http://www.ncbi.nlm.nih.gov/books/NBK470550/

2. Barr, Richard G (2017). Elastography a Practical : "Elastography of the Prostate", 87-99.

3. Harvey CJ, Pilcher J, Richenberg J, Patel U, Frauscher F. Applications of transrectal ultrasound in prostate cancer. $\mathrm{Br} \mathrm{J}$ Radiol. 2012;85(Spec Iss 1):S3-S17. doi:10.1259/bjr/56357549

4. Tangel MR, Rastinehad AR. Advances in prostate cancer imaging. F1000Res. 2018;7:1337. doi:10.12688/f1000research.14498.1

5. Barr RG, Cosgrove $D$, Brock $M$, et al. WFUMB Guidelines and Recommendations on the Clinical Use of Ultrasound Elastography: Part 5. Prostate. Ultrasound in Medicine \& Biology. 2017;43(1):2748. doi:10.1016/j.ultrasmedbio.2016.06.020

6. Dietrich CF, Barr RG, Farrokh A, et al. Strain
Elastography - How To Do It? Ultrasound Int Open. 2017;3(4):E137-E149. doi:10.1055/s-0043119412

7. Kamoi K, Okihara K, Ochiai A, et al. The Utility of Transrectal Real-Time Elastography in the Diagnosis of Prostate Cancer. Ultrasound in Medicine and Biology. 2008;34(7):1025-1032. doi:10.1016/j.ultrasmedbio.2007.12.002

8. Giurgiu CR, Manea $C$, Crişan N, Bungărdean C, Coman I, Dudea SM. Real-time sonoelastography in the diagnosis of prostate cancer. Med Ultrason. 2011;13(1):5-9.

9. El Fattah Hassan Gadalla AA, El Rahman SFA Anis SE, El-Sayed khalil M. Value of ultrasound elastography versus transrectal prostatic biopsy in prostatic cancer detection. The Egyptian Journal of Radiology and Nuclear Medicine. 2015;46(3):761768. doi:10.1016/j.ejrnm.2015.05.009

\section{ĐĂC ĐIỂM KỸ THUÂTT, TÍNH AN TOÀN CỦA NộI SOI BÓNG ĐƠN Ở BÊ̂NH NHÂN CHẢY MÁU TIÊU HÓA NGHI Ở RUỘT NON}

\section{TÓM TẮT}

Mục tiêu: Mô tả đặc điểm kỹ thuật và tính an toàn của nội soi bóng đợn ở bệnh nhân nghi chảy máu tiêu hóa (CMTH) ở ruột non. Đối tượng và phương pháp: Có 89 bệnh nhần nghi CMTH tại ruột non đước đưa vào nghiên cứu. Trước khi thực hiện nội soi ruột non bóng đơn (NSRNBĐ), tất cả các bềnh nhân đều được nôi soi dạ dày-tá tràng và đại tràng, nhưng khổng phát hiện thấy tổn thương gây CMTH. Các thông số theo dõ̃i: Đương soi, thời gian, chiều dài ruột non soi được và biến chứng. Kết quả: Tỷ lệ soi theo đường miệng, đường hậu môn và cả 2 đường, tương ứng là: $35,9 \%, 14,6 \%$ và $49,5 \%$. Thời gian trung bình (phút) theo đường miệng, đường hậu môn và cả hai đường, tương ứng là: $95,31 \pm 40,42 ; 51,92 \pm 29,69$ và $161,70 \pm 16,46$. Chiêuu dài trung bình (mét) của ruột non nội soi qua đường miệng, đường hậu môn và cả hai đường chiếm tỷ lệ tương ứng là: $2,49 \pm 0,94$; $1,32 \pm 0,74$ và $2,94 \pm 1,26$. Biến chứng hay gặp sau NSRNBĐ là viêm tụy cấp mức độ nhẹ: 3/89 bẹnh nhân $(3,4 \%)$. Kết luận: Nội soi bóng đơn là một kỹ thuật an toàn, có hiệu trong chẩn đoán bệnh lý tại ruột non.

Tư khóa: Chảy máu tiêu hóa, nội soi ruột non bóng đơn

\section{SUMMARY}

${ }^{1}$ Bênh viên Bach Mai

²Bệnh viện TWQÐ

${ }^{3}$ Bệnh viện 103-HVQY

Chịu trách nhiệm chính: Đỗ Anh Giang

Email: dranhgiangbm@gmail.com

Ngày nhận bài: 6.8.2021

Ngày phản biện khoa học: 6.10 .2021

Ngày duyệt bài: 15.10.2021
Đỗ Anh Giang'1 Vũ Văn Khiên' Phạm Thị Thu Hồ ${ }^{1}$, Dương Quang Huy ${ }^{3}$

\section{CHARACTERISTICS AND SAFETY OF SINGLE BALOON ENTEROSCOPY IN PATIENTS WITH \\ SUSPECTED IN SMALL BOWEL BLEEDING}

Aim: Characteristics and safety of single balloon enteroscopy (SBE) in patients with suspected in smal bowel bleeding. Patient and methods: There were 89 patients with suspected in small bowel bleeding in the study. Before performing SBE, all patients underwent upper GI endoscopy and colonoscopy, but no lesions were detected. Follow-up parameters: endoscopic path, length of endoscopic small intestine, endoscopic time and complications. Results: The percentages of oral, anal and both routes were $35.9 \%, 14.6 \%$ and $49.5 \%$, respectively. Mean time (minutes) by oral, anal and both routes were $95.31 \pm$ $40.42 ; 51.92 \pm 29.69$ and $161.70 \pm 16.46$, respectively. The mean length (meters) of the small intestine through endoscopic oral, anal and both routes were $2.49 \pm 0.94 ; 1.32 \pm 0.74$ and $2.94 \pm$ 1.26 , respectively. The common complication after SBE is mild acute pancreatitis: $3 / 89$ patients (3.4\%). Conclusion: Single-balloon endoscopy is a safe technique in the diagnosis of patients with suspected small bowel bleeding.

Key words: GI bleeding, single balloon enteroscopy

\section{I. ĐĂT VẤN ĐỀ}

Trong các thập kỷ trước, CMTH tại ruột non vẫn là một cơ quan "bí hiểm", vì khồng có các thiết bị hiện đại thăm dò trực tiếp tại ruột, giúp chẩn đoán chính xác bệnh. Các biện pháp chẩn đoán hình ảnh khác như chụp cộng hưởng từ ồ bụng, chụp cắt lớp vi tính ổ bụng, chụp xạ hình ổ bụng và kể cả nội soi viên nang... cũng chỉ là các phương pháp trợ giúp cho chẩn đoán cho bệnh 
nhân nghi ngờ CMTH tại ruột non. Từ khi kỹ thuật nội soi ruột non bóng đơn và bóng kép ra đời, đã giúp cho chẩn đoán và can thiệp điều trị qua nội soi. Trong 20 năm qua, tại Việt Nam, một số bệnh viện đã được trang bị các thiết bị máy nội soi ruột non, để giúp chẩn đoán các bệnh lý ruột non [1]. Tuy nhiên, đây là kỹ thuật xẩm phạm, nên có thể có các biến chứng sau điều trị. Vì vậy, đề tài này nghiên cứu về: Đặc tính và tính an toàn của nội soi ruột non trong chẩn đoán ở bệnh nhân nghi ngờ CMTH tiêu hóa tại ruột non.

\section{II. ĐỐI TƯỢNG VÀ PHƯƠNG PHÁP NGHIÊN CỨU 2.1. Đối tượng \\ *Tiêu chuẩn nghiên cứu: Có 89 bệnh nhân} nghi CMTH tại ruột non đã được NSRNBĐ tại Bênh viện Bạch Mai và Bênh viện TWQĐ 108 từ 01/2014 đến 12/2019. Tất cả các bệnh nhân đều được nội soi da dày, đại tràng trước khi thực hiện NSRNBĐ.

*Tiêu chuẩn loại trừ: Bệnh nhân già yếu, có suy tim, suy hô hấp, chống chỉ định nội soi, rối loạn huyết động, tiền sử mổ dính ruột nhiều lần, nghi tắc ruột cơ học không thể can thiệp qua nội soi....

\subsection{Phương pháp}

+ Phương pháp nghiên cứu: Hồi cứu, tiến cứu, mô tả, cắt ngang. Nơi thực hiện nội soi: Khoa Nội tiêu hóa- Bệnh viện TWQĐ 108 và khoa Thăm dò chức năng- Bệnh viện Bạch Mai.

+ Phương tiện: Máy NSRRNBE của Olympus (Nhật Bản) và các thiết bị phụ trợ khác. Chuẩn bị bệnh nhân cho nội soi giống như khi nội soi đại tràng (bệnh nhân uống Fortran). Thực hiện nội soi ruột non dưới gây mê.

+ Nguyên lý và quy trình NSRNBĐ được thực hiện gồm 8 bước ${ }^{5}$ : Bơm bóng (bước 1 ), đẩy máy nội soi (bước 2), cố định đầu máy soi (bước 3), tháo hơi ở đầu bóng (bước 4), bẩy overtube (bước 5), bơm bóng (bước 6), kéo cả overtube và dây soi, lặp lại thao tác ban đầu (bước 8).

+ Thông số theo dõi: Đường soi, chiều dài nội soi ruột non soi được, thời gian nội soi, các biến chứng và tác dụng phụ không mong muốn

\section{KẾT QUẢ NGHIÊN CỨU}

Chúng tôi đã tiến hành nội soi ruột non bóng đơn cho 89 bệnh nhân nghi ngờ CMTH tại ruột non theo đường miệng hoặc theo đường hậu môn hoặc kết hợp cả hai đường. Kết quả theo dõi đặc điểm kỹ thuật và tính an toàn cụ thể như sau:

Bảng 1. Đường nội soi ruột non bóng đơn Đường nôi soi

Đường miêng

Đường hậu môn

$32 / 89(36,0 \%)$

Cả hai đường $\quad 44 / 89(49,4 \%)$

Nhận xét: Tỷ lệ nội soi ruột non theo đường miênng, đường hậu mồn và cả 2 đường tương ứng là: $36,0 \% ; 14,6 \%$ và $49,4 \%$.

Bảng 2. Chiều dài ruột non soi được (m)

\begin{tabular}{|c|c|c|c|}
\hline \multicolumn{2}{|c|}{$\begin{array}{l}\text { Chiều dài ruột non } \\
\text { soi được (m) }\end{array}$} & $\begin{array}{c}\text { Số bệnh } \\
\text { nhẩn }\end{array}$ & Tỷ lệ \\
\hline \multirow{6}{*}{$\begin{array}{l}\text { Đường } \\
\text { miệng }\end{array}$} & $<1$ & 3 & \\
\hline & $1-<2$ & 11 & 14,5 \\
\hline & $2-<3$ & 31 & 40,8 \\
\hline & $\geq 3$ & 31 & 40,8 \\
\hline & Cộng & 76 & 100 \\
\hline & $\begin{array}{l}\text { Trung } \\
\text { bình }\end{array}$ & \multicolumn{2}{|c|}{$\begin{array}{c}2,49 \pm 0,94 \\
(0,3-4,5)\end{array}$} \\
\hline \multirow{6}{*}{$\begin{array}{l}\text { Đường } \\
\text { hậu } \\
\text { mồn }\end{array}$} & $<1$ & 15 & 26,3 \\
\hline & $1-<2$ & 30 & 52,6 \\
\hline & $2-<3$ & 9 & 15,8 \\
\hline & $\geq 3$ & 3 & 5,3 \\
\hline & Cộng & 57 & 100 \\
\hline & $\begin{array}{l}\text { Trung } \\
\text { bình }\end{array}$ & \multicolumn{2}{|c|}{$\begin{array}{c}1,32 \pm 0,74 \\
(0,2-4,0)\end{array}$} \\
\hline \multirow{6}{*}{$\begin{array}{l}\text { Cả } 2 \\
\text { đường }\end{array}$} & $<1$ & 4 & 4,4 \\
\hline & $1-<2$ & 12 & 13,5 \\
\hline & $2-<3$ & 20 & 22,5 \\
\hline & $\geq 3$ & 53 & 59,6 \\
\hline & Cộng & 89 & 100 \\
\hline & $\begin{array}{c}\text { Trung } \\
\text { bình }\end{array}$ & \multicolumn{2}{|c|}{$\begin{array}{c}2,94 \pm 1,26 \\
(0,3-6,6) \\
\end{array}$} \\
\hline Tỷ lệ sc & ruột non & $21 / 89$ & 6 \\
\hline
\end{tabular}

Nhận xét: Chiều dài trung bình (mét) của ruột non soi qua đường miêng, đường hâuu môn và cả hai đường chiếm tỷ lệ tương ứng là: 2,49 $\pm 0,94 ; 1,32 \pm 0,74$ và $2,94 \pm 1,26$. Tỷ lệ soi hết ruột (theo cả 2 đường) là: $21 / 89(23,6 \%)$

Bảng 4. Biến chứng trong và sau nội soi ruôt non bóng đơn

\begin{tabular}{|c|c|}
\hline Các biến chứng & $\mathbf{n ~ ( \% )}$ \\
\hline Thưng ruột & $0 / 89(0 \%)$ \\
\hline Chảy máu sau thủ thuật & $1 / 89(1,1 \%)$ \\
\hline Viêm tụy cấp mức độ nhẹ & $3 / 89(3,4 \%)$ \\
\hline Nhiềm trùng đường mật & $1 / 89(1,1 \%)$ \\
\hline Tổng & $\mathbf{5 / 8 9}(\mathbf{5 , 6 \% )}$ \\
\hline
\end{tabular}

Nhân xét: Có 01 bệnh nhân CMTH nhe sau kẹp clip, 01 bệnh nhân nhiễm trùng đường mật. Có 03 bệnh nhân viêm tụy cấp mức độ nhẹ. Tổng biến chứng: 5,6\%

Bảng 4. Thời gian thực hiện nội soi ruột non bóng đơn (phút)

\begin{tabular}{|c|c|c|c|c|}
\hline Đường soi & Số BN & Trung bình & Lớn nhất & Nhỏ nhất \\
\hline Đường miệng & 32 & $95,31 \pm 40,42$ & 180 & 15 \\
\hline
\end{tabular}




\begin{tabular}{|c|c|c|c|c|}
\hline Đường hậu môn & 13 & $51,92 \pm 29,69$ & 120 & 15 \\
\hline Cả hai đường & 44 & $161,70 \pm 16,46$ & 200 & 135 \\
\hline
\end{tabular}

Nhận xét: Thời gian nội soi trung bình (phút) của NSRNBĐ qua đường miệng, đường hậu môn và cả hai đường tương ứng là: 95,31 \pm 40,42; 51,92 $\pm 29,69$ và 161,70 $\pm 16,46$

Bảng 5. Tác dụng không mong muốn sau nội soi ruột nôn bóng đớn

\begin{tabular}{|c|c|c|c|c|}
\hline Triệu chứng & Đường miệng & Đường hậu môn & Cả hai & Cộng \\
\hline Mệt mỏi & $25(33,8)$ & $10(13,5)$ & $39(52,7)$ & $\mathbf{7 4}(\mathbf{8 3}, \mathbf{1})$ \\
\hline Đau bụng & $13(28,9)$ & $10(22,2)$ & $22(48,9)$ & $\mathbf{4 5}(\mathbf{5 1}, \mathbf{7})$ \\
\hline Rát họng & $5(26,3)$ & $0(0,0)$ & $14(73,7)$ & $\mathbf{1 9}(\mathbf{2 1}, \mathbf{3})$ \\
\hline Chướng bụng & $5(45,5)$ & $4(36,4)$ & $2(18,2)$ & $\mathbf{1 1}(\mathbf{1 2}, \mathbf{4})$ \\
\hline Buồn nôn & $480,0)$ & $1(20,0)$ & $0(0,0)$ & $\mathbf{5}(\mathbf{5 , 6 )}$ \\
\hline
\end{tabular}

Nhận xét: Triệu chứng mệt mỏi và đau bụng là các dấu hiệu không mong muốn thường gặp nhất sau nội soi tương ứng là: $83,1 \%$ và $51,7 \%$.

\section{BÀN LUẬN}

4.1. Lựa chọn đường soi. Lựa chọn đường miệng, đường hậu môn hay phối hợp cả hai đường là quyết định của bác sỹ nội soi. Thông thường chúng tôi lựa chọn đường nội soi trong lần soi đầu của bệnh nhân dựa theo vị trí tổn thương được gợi ý khi thăm khám lâm sàng hoặc kết hợp với các phương pháp chẩn đoán hình ảnh khác như chụp CLVT, siêu âm, $X$ quang. Trong trường hợp không xác định được vị trí tổn thương thì đường miệng là đường tiếp cận trước tiên do khả năng đi sâu của ống soi trong ruột non tốt hơn và thuận lợi hơn so với đường hậu môn.

Trong nghiên cứu của chúng tôi (bảng 1) số bệnh nhân được nội soi ruột non theo đường miệng đạt: 32/89 bệnh nhẩn (35,9\%), đường hậu môn: $13 / 89$ bệnh nhân $(14,6 \%)$ và cả hai đường: 44/89 bệnh (49,5\%). Như vậy, có gần $50 \%$ số bệnh nhân được thực nội soi ruột non bằng cả hai đường. Mục đích của chúng tôi mong muốn khảo sát hết toàn bộ chiều dài ruột non và tránh bỏ sót tổn thương.

Nghiên cứu của Kiều Văn Tuấn và CS cho biết tỷ lệ NSRNBĐ theo đường miệng, đường hậu môn và cả hai đường chiếm tỷ lệ tương ứng là: $37 \% ; 20 \%$ và $43 \%$ [1]. Nghiên cứu của Kim T] và cs khi tiến hành NSRNBĐ tại Hàn Quốc cho 65 bệnh nhân có chỉ định nội soi ruột non, kêt quả cho biết số bệnh nhân được nội soi theo đường miệng là: 39/65 bệnh nhẩn (60\%) và số bệnh nhẩn được nội soi theo đường hậu môn là: 26/65 bệnh nhân (40\%) [2]. Nghiên cứu của Chang CW và CS khi thực hiện NSRNBĐ cho 168 bệnh nhân được nội soi ruột non cũng cho biết số bệnh nhẩn được nội soi ruột non theo đường miệng, đường hậu môn và cả hai đường chiếm tỷ lệ tương ứng là: $22,6 \%, 19,6 \%$ và $53,7 \%$ [3].

4.2. Tỷ lệ soi hết ruột non qua nội soi ruột non bóng đơn. Nội soi hết toàn bộ ruột non (total enteroscopy) là một chỉ tiêu cân phải đạt được khi thực hành NSRNBĐ hoăc bóng kép. Nội soi hết toàn bộ ruột non sẽ giúp không bỏ sót tổn thương. Trong nghiên cứu của chúng tôi (bảng 3.35) số bệnh nhân được nội soi hết toàn bộ ruột non chiếm tỷ lệ: $21 / 89$ bệnh nhân $(23,6 \%)$. Nghiên cứu của Kiều Văn Tuấn và CS cho biết tỷ lệ soi hết ruột non bằng bóng đơn đạt $25,6 \%$ [1].

Trên thế giới có rất nhiều nghiên cứu báo cáo về tỷ lệ soi hết ruột non của NSRNBĐ. Tỷ lệ này dao động từ 40 - 86\% [6]. Tuy nhiên, tỷ iệ soi hết toàn bộ ruột non phụ thuộc vào rất nhiều yếu tố như tiền sử phẫu thuật bụng, dính ruột, tổn thương ruột non gây tắc hoặc hẹp lòng ruột hoặc do khả năng chịu đựng của bệnh nhẩn trong quá trình nội ruột non [4]. Trong nghiên cứu của chúng tôi, không có trường hợp nào soi hết toàn bộ ruột non chỉ qua 1 đường miệng hoặc đường hậu môn. Tuy nhiên, nghiên cứu của tác giả Chen WG và cs thực hiện trên 400 bệnh nhân đã báo cáo có 2 trường hợp soi hết toàn bộ ruột non qua đường miệng [5]. Nghiên cứu của Yamamoto $H$ và cs báo cáo 2 trường hợp soi hết ruột non chỉ qua đường miệng trong tổng số 28 bệnh nhân [6]. Theo chúng tôi, có được kết quả này là do Trung Quốc và Nhật Bản là những nước có nhiều năm kinh nghiệm về nội soi ruột non, số lượng bệnh nhân trong nghiên cứu tương đối lớn tạo điều kiện nâng cao trình độ kỹ thuật của bác sỹ nội soi. Tuy nhiên, các số liệu nghiên cứu này còn rất ít

4.3. Thời gian thực hiện nội soi ruột non bóng đơn. Thời gian nội soi ruột non cho bóng đơn hoăc bóng kép cũng là một thông số đánh giá chất lượng của nội soi. Thời gian nội soi phụ thuộc rất nhiều vào kinh nghiệm của người làm nội soi. Những bác sỹ đã có kinh nghiệm nội soi lâu năm, thao tác thành thạo... thì thời gian nội soi sẽ ít hơn so với bác sỹ mới bắt đầu nội soi. Thời gian nội soi cũng phụ thuộc tình trạng bệnh 
nhân (thể trạng béo, thể trạng gầy và các bệnh kèm theo)

Trong nghiên cứu của chúng tôi (bảng 3 ) cho biết thời nội soi ruột non theo đường miệng, đường hậu môn, cả hai đường và thời gian nội soi trung bình (phút) chiếm tỷ lệ tương ứng là: $95,31 \pm 40,42 ; 51,92 \pm 29,69 ; 161,70 \pm 16,46$ và $121,80 \pm 51$ (phút). Nghiên cứu của Kiêuu Văn Tuấn và CS trên 92 bệnh nhân với 161 lần soi cũng cho biết thời gian NSRNBĐ trung bình cho một lần soi là $50 \pm 25$ phút [1].

4.4. Biến chứng trong và sau nội soi ruột non bóng đơn. Nội soi ruột non là những thủ thuật xâm lấn, do vậy có thể có các biến chứng trong quá trình thao tác và tác dụng không mong muốn. Các biến chứng này phụ thuộc rất nhiều yêu tố như: tình trạng bệnh nhân (béo, gầy..), kinh nghiệm của người làm nội soi và thiết bị nội soi (cũ hay mới)...

Biến chứng viêm tụy cấp. Trong nghiên cứu của chúng tôi trình bày trong (bảng 4) cho biết có $3 / 89$ bệnh nhân $(3,4 \%)$ có viêm tụy cấp thể nhẹ (viêm tụy cấp thể phù nề -xung huyết). Tuy nhiên, ba bệnh nhân này đều đáp ứng với điều trị, thông qua: Nhịn ăn, truyền đủ dịch và kháng sinh đường tĩnh mạch. Để chẩn đoán đúng bệnh nhân có viêm tụy cấp cần phải theo dõi chặt chẽ trên lâm sàng (thăm khám ổ bụng định kỳ), xét nghiệm lipase, amylase máu và nước tiểu....

Biến chứng CMTH tái phát sau thủ thuật. Chúng tôi gặp $1 / 89$ bệnh nhân $(1,1 \%)$ có CMTH nhe sau cắt polyp (đã kẹp chân polyp sau cắt). Đây là bệnh nhân có bệnh lý đái tháo đường kèm theo, do vậy, nguy cơ CMTH tái phát tại vị trí chân polyp đã cắt có thể xảy ra. Rất may, polyp nằm ở hồi tràng (cách van Bauhin $6 \mathrm{~cm}$ ), do vậy, chúng tôi đã nội soi lại (sau 12 giờ CMTH tái phát) và kẹp thêm 01 clip vào vị trí chân polyp đang chảy máu. Sau 72 theo dõi bệnh nhân ổn định và ra viên. Bài học kinh nghiệm của chúng tôi cần rút ra rằng cần phải cẩn thận và cân nhắc trước khi can thiệp cho bệnh nhân $\mathrm{CMTH}$ ruột non có bệnh lý nền kèm theo (đái tháo đường typ II, tăng huyết áp, thường xuyên sử dụng thuốc NSAIDS...)

4.5. Tác dụng không mong mong muốn sau NSRNBĐ. Trong nghiên cứu của chúng tôi (bảng 4) cho biết các triệu chứng không mong muốn sau NSRNBĐ gồm: Mệt mỏi $(83,1 \%)$, đau bụng $(51,7 \%)$, rát họng $(21,3 \%)$, chướng bụng $(12,4 \%)$, buồn nôn $(5,6 \%)$.

Triệu chứng hay gặp nhất là mệt khó chịu chiếm $83,1 \%$ được cho là tác dụng phụ của thuốc Propofol và xảy ra ngay sau khi bệnh nhân tỉnh. Tuy nhiên bệnh nhân nhanh chóng trở về bình thường sau nội soi vài giờ.

Đau bụng và chướng bụng là 2 triệu chứng do nội soi gây ra. Quá trình nội soi phải bơm hơi làm căng giãn ruột giúp ống soi đi sâu vào trong ruột non dễ dàng và quan sát niêm mạc ruột non tốt hơn, vì vậy dễ gây chướng hơi là triệu chứng khó tránh khỏi. Bụng chướng hơi nhiêu làm cho bệnh nhân khó chịu ở vùng bụng, thậm chí gây đau bụng. Để khắc phục các triệu chứng này, khi kết thúc nội soi, người thực hiện thủ thuật phải hút hết hơi trong các quai ruột.

Rát họng chỉ gặp ở những trường hợp nội soi đường miệng do ống soi khi đi qua họng được kéo và đầy nhiều lần trong một khoảng thời gian dài khiến phù nề, xây xước niêm mạc hầu họng gây cảm giác đau rát khó chịu cho bệnh nhân. Phần lớn trường hợp triệu chứng đau rát họng tự mất đi mà không cần điều trị gì.

\section{KẾT LUÂ̂N}

Tỷ lệ NSRNBĐ theo đường miệng, đường hậu môn và cả 2 đường, tương ứng là: $35,9 \%$, $14,6 \%$ và $49,5 \%$. Thời gian trung bình theo đường miệng, đường hậu môn và cả hai đường, tương ứng là: 95,31 \pm 40,42 (phút), 51,92 \pm 29,69 (phút) và $161,70 \pm 16,46$ (phút). Tỷ lệ soi hết ruột non chiếm: $21 / 89$ bệnh nhân $(23,6 \%)$. Biến chứng hay gặp sau NSRNBĐ là viêm tụy cấp mức độ nhẹ: 3/89 bệnh nhân (3,4\%).

\section{TÀI LIÊU THAM KHẢO}

1. Kiều Văn Tuấn, Trân Viêtt Hùng, Nguyễn Manh Trường và công sự (2012). Vai trò của nội soi ruôtt non bóng đơn trong chẩn đoán và điều tri bệnh lý ruột non. Tap chí y học $Y$ học thực hành. 12: $98-102$

2. Kim T. J., Kim E. R., Chang D. K., et al. (2017). Comparison of the Efficacy and Safety of Single- versus Double-Balloon Enteroscopy Performed by Endoscopist Experts in SingleBalloon Enteroscopy: A Single-Center Experience and Meta-Analysis. Gut and Liver. 11(4): 520-527

3. Chang C. W., Chang C. W., Lin W. C., et al, (2017). Efficacy and Safety of Single-Balloon Enteroscopy in Elderly Patients. International Journal of Gerontology. 11: 176-178

4. Mensink P. B., Haringsma J., Kucharzik T., et al. (2007). Complications of double balloon enteroscopy: a multicenter survey. Endoscopy. 39(7): 613-615

5. Chen W. G., Shan G. D., Zhang $H_{.}$et al. (2016). Double-balloon enteroscopy in small bowel diseases Eight years single-center experience in China. Medicine. 95(42): 1-6

6. Yamamoto H. (2005). Double-Balloon Endoscopy. Clinical Gastroenterology and Hepatology. 3: s27-s29. 


\section{ĐÁNH GIÁ KẾT QUẢ ĐIỀU TRI PHẪU THUẬT U HẬU NHÃN CẦU TẠI BỆNH VIỆN K}

\section{TÓM TẮT}

Mục tiêu: Đánh giá kết quả điều trị phẫu thuật u hậu nhãan cầu. Đối tượng và phương pháp nghiên cứu: nghiên cứu cắt ngang, hồi cứu và tiến cứu, gồm 30 bênh nhân u hậu nhãn câuu được chẩn đoán, điều trị phâuu thuật tại khoa Ngoại Thần Kinh - bệnh viện K từ 01/2017 đến 06/2021. Kết quả: Tỷ lệ nam/nữ là $1,14 / 1$; tuổi trung bình là $37,8 \pm 22,6$ (4-71 tuổi). Triệu chứng lâm sàng thường hay gặp nhất là lồi măt (90\%), đau mắt $(86,7 \%)$, giảm thị lực $(76,7 \%)$. Khối u lành tính $(43,4 \%)$, u ác tính $(56,7 \%)$; trong đó hay gặp nhất là u màng não $(23,3 \%)$, sarcoma cơ vân thể bào thai $(13,3 \%)$, carcinoma không sừng hóa xâm nhâp $(10 \%)$. Kết quả lấy toàn bô u và gần toàn bộ là $46,7 \%$ và $33,3 \%$. Không có trường hợp nào tử vong, chảy máu do phẫu thuật. Kết quả khám lại hiện tại: Có $8 / 30(26,7 \%)$ bệnh nhần tử vong, trung bình 9,0 04,3 tháng, các loại giải phẫu bệnh (Carcinom không sừng hóa xâm nhập; Sarcoma (cơ vân thể hốc, xương, cơ vân thể bào thai, sun trung mô, xơ bì lồi); Carcinom biểu bì nhày độ cao). U tiến triển, tái phát: có $6 / 30$ $(20 \%)$, trung bình $9,0 \pm 4,3$ tháng, các loại giải phấu bệnh (Hemangiopericytome malin độ III, Sarcoma (cơ vẩn thể hốc, xương, cơ vân thể bào thai, xớ bì lồi), Carcinom không sừng hóa xâm nhập). Còn u tồn dư, u lành tính, không tiến triển: có $9 / 30$ (30\%), trung bình $15,67 \pm 12,7$ tháng, các loại giải phẩu bệnh (u màng não, loạn sản xơ xương, u mạch thể tĩnh mạch, giả u - viêm mạn). Không còn u, u lành tính: có 4/30 $(13,3 \%)$, trung bình $19,25 \pm 8,9$ tháng, các loại giải phẫu bệnh (Swhannoma, u màng não). Kết Iuận: Phẫu thuật là phương pháp hiệu quả để chẩn đoán và điều trị các u hậu nhãn cầu. Tỉ lệ lấy toàn bộ u và gần toàn bộ là $46,7 \%$ và $33,3 \%$, tỉ iệ biến chứng sau mổ thấp (Ćó 4 ca chiếm 13,33\% trường hợp nhiêm trùng tại chố hốc mắt. Không có biến chứng chảy máu nội nhãn hay máu tụ nội sọ, rò dịch não tủy, tràn khí).

Từ khóa: U hậu nhãan cầu, u hốc mắt, phẫu thuật qua sọ, mở trần hốc mắt.

\section{SUMMARY}

\section{RESULTS OF SURGICAL TREATMENT OF ORBITAL TUMORS AT K HOSPITAL}

Objective: Evaluation of treatment of patients with orbital tumors in $\mathrm{K}$ national the combination of radiation therapy and/or post-operative chemicals. Methods: Cross-sectional, retrospective and prospective study, 30 patients with orbital tumor is diagnosed and operated at the Department of

\section{*Bênh viên $K$}

Chịu trách nhiệm chính: Nguyễn Đức Liên

Email: drduclien@gmail.com

Ngày nhận bài: 10.8 .2021

Ngày phản biện khoa học: 7.10.2021

Ngày duyệt bài: 15.10.2021

\section{Nguyễn Đức Liên*, Hoàng Văn Luyện*}

Neurosurgery - K national Hospital from $1 / 2017$ to $6 / 2021$. Results: The ratio male/female $=1,14 / 1$. Mean age of the patient was $37.8 \pm 22.6$ years (age range 4 - 71 years). The most common presenting symptoms were proptosis in 27 patients $(90 \%)$, eye pain $86,7 \%$; vision loss $76,7 \%$. There were $17(56,7 \%)$ patients with malignant tumors, $13(43,4 \%)$ with benign tumors. The most common lesion types were meningioma $(23.3 \%)$, embryonic rhabdomyosarcoma $(13.3 \%)$, invasive nonkeratinizing carcinoma (10\%). Total resection was achieved in 14 patiens $(46,7 \%)$ while subtotal resection was 33,3\%. No one died, intracranial hematoma in this study. Current follow-up results: $8 / 30(26.7 \%)$ patients died, average $9.0 \pm 4.3$ months, pathologic types (non-keratinizing carcinoma; Skeletal muscle sarcoma, bone sarcoma, embryonic rhabdomyosarcoma, chondrosarcoma, scleroderma sarcoma, high-grade epidermal carcinoma.Tumor progression, recurrence: $6 / 30(20 \%)$, average $9.0 \pm$ 4.3 months, pathologic types (Hemangiopericytome malin grade III, Sarcoma (skeletal muscle, bone, embryonic rhabdomyosarcoma, scleroderma), non keratinizing carcinoma). Residual tumors, benign tumors, no progression: $9 / 30(30 \%)$, average $15.67 \pm$ 12.7 months, pathologic types (meningioma, fibrous dysplasia, venous vascular tumor, pseudotumor chronic inflammation). No tumor, benign tumor: 4/30 $(13.3 \%)$, average $19.25 \pm 8.9$ months, pathological types (Swhannoma, meningioma). Conclusion: Surgery is an effective approach for the management of orbital tumors. Total resection was achieved in 14 patiens $(46,7 \%)$ while subtotal resection was $33,3 \%$. The rate of postoperative complications is low (There were 4 cases $(13,33 \%)$ of infection at the eye socket. There was not intraorbital or intracranial hematoma, cerebrospinal fluid leak, pneumonia intracranial).

Keywords: Retrobulbar tumor, orbital tumor, transcranial approaches, transcranial superior orbitotomy.

\section{I. ĐĂT VẤN ĐỀ}

U hậu nhãn cầu là một bệnh lý hiếm gặp, theo Hội ung thư Hoa Kỳ thì tần suất mắc bệnh chỉ khoảng 1/100000 người [7]. Do hốc mắt là vùng có thể tích nhỏ hẹp, cấu trúc giải phẫu phức tạp, thương tổn bệnh lý rất đa dạng và khó về mặt chẩn đoán cũng như điều trị do triệu chứng đa dạng, phức tạp và không đặc hiệu nển thường phân biệt với bệnh lý khác ở mắt và các cơ quan lân cận. U hậu nhãn cầu nguyên phát chiếm $70 \%$, từ tổ chức kế cận khoảng $23 \%$, di căn từ các tổ chức xa khác chiếm $4 \%$, từ các bệnh hệ thống chiếm 3\%[2],[6].

Về chẩn đoán: với sự phát triển của chụp cắt lớp vi tính, chụp cộng hưởng từ đã giúp chẩn 
đoán chính xác vị trí u, định hướng chẩn đoán, định hướng chiến lược điều trị bệnh. Về điều trị, với tiến bộ trong vi phẫu thần kinh, phẫu thuật nội soi và hệ thống định vị thần kinh, dao hút u bằng siêu âm đã giúp tiếp cận các loại khối u hậu nhãn cầu một cách chính xác và an toàn. Phẫu thuật là lựa chọn đầu tiên nhằm mục đích chẩn đoán giải phẫu bệnh, giải quyết tổn thương. Có 3 đường tiếp cận: đường trực tiếp vào hốc mắt, đường qua sọ trần và thành bên hốc mắt và đường mổ nội soi qua mũi để tiếp cận tổn thương thành trong hốc mắt, một số trường hợp có thể phối hợp các đường mổ trên. Chọn lựa đường mổ được làm chủ yếu dựa trên vị trí, loại tổn thương, mức độ lan tỏa của u cũng như mục đích của phầu thuật $[1],[5],[6]$.

Tại bệnh viện $K$, có đủ các chuyên khoa để điều trị cho bệnh lý u hậu nhãn cầu: chuyên khoa ngoại thần kinh, xạ trị, hóa trị, triển khai thường quy từ năm 2017. Vî̀ vậy, chúng tôi tiến hành đề tài: "Đánh giá kết quả điêu trị phẫu thuật u hậu nhãn cầu tại bệnh viện $\mathrm{K}^{\prime \prime}$ là cần thiết, nhằm phục vụ cổng tác điều trị cũng như tiên lượng bệnh lý này.

\section{II. ĐỐI TƯỢNG VÀ PHƯƠNG PHÁP NGHIÊN CỨU}

Tiêu chuâin lựa chon: gồm các bệnh nhân được chẩn đoán và phẫu thuật u hậu nhãn cầu tại bệnh viện $\mathrm{K}$ từ 01/2017 đến 06/2021; được chụp phim cộng hưởng từ hoặc cắt lớp vi tính ổ mắt trước mổ.

Tiêu chuẩn loại trừ: các tổn thương hậu nhãn cầu cả hai bên mắt, tình trạng nhiếm trùng, có bệnh lý toàn thân nặng (suy tim, suy thận, COPD...)

Phương pháp nghiên cứu: nghiên cứu cắt ngang, hồi cứu và tiến cứu.

Nội dung nghiên cứu: Gồm các thông tin cá nhân: tuối, giới; các triệu chứng lâm sàng ; Vị trí của u xác định trên CT hoặc MRI: u hậu nhãn câu được chia theo tác giả Boari (2011):
(1) u ở đỉnh ở mắt (khi khối u nằm ở phía sau mặt phẳng của cánh lớn xương bướm (lát cắt Axial - hình 1)),

(2) u ở giữa đỉnh ổ mắt và nhãn cầ; ở vùng này lại được chia thành 3 vùng tương quan với thần kinh thị: trên ngoài, trên trong, vùng dưới (theo mặt phẳng coronal, mỗi vùng là $120^{\circ}$ như hình 1).

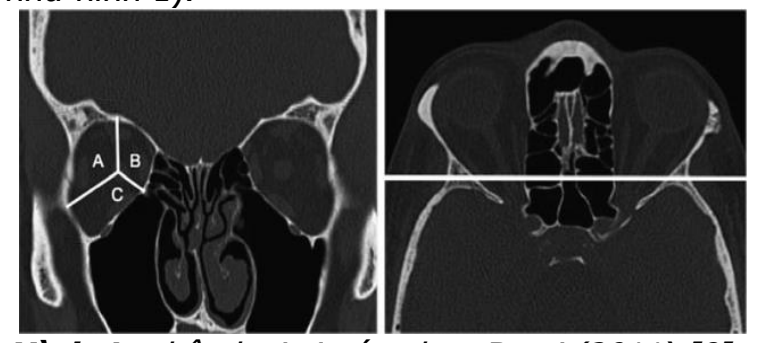

Hình 1: phân loại vi trí u theo Boari (2011) [8]

Mức độ lấy u: Được chia làm 4 mức độ dựa theo Margalit $N$ có biến đổi [4] Lấy toàn bộ u (lấy hết $\mathrm{u}$ về đại thể kiểm tra bằng $\mathrm{CT}$ hoặc MRI sau mổ); lấy gần hết u ( $\geq 90 \%$ thể tích u); lây u bán phần (<90\% thể tích $u)$; sinh thiết u

Đánh giá kết quả gồm: biến chứng và kết quả sớm sau mổ được đánh giá tại thời điểm ra viện, và kết quả khám lại sau 03 tháng và hiện tại.

\section{KẾT QUẢ NGHIÊN CỨU}

Giới: Tỷ lệ mắc bệnh nam và nữ lần lượt là: $53,3 \%$ và $46,7 \%$.

Tuổi: Tuổi nhỏ nhất 4 tuổi, lớn nhất 71 tuổi; Trung bình $37,8 \pm 22,6$.

Diễn biến bệnh: Lý do đến viện chủ yếu là lồi mắt $(90 \%)$, đau mắt $(86,7 \%)$, giảm thị lực $(76,7 \%)$, liệt dây thần kinh vận nhãn $9 / 30$ $(30 \%)$, nhìn đôi $5 / 30(16,7 \%)$. Thời gian khởi phát bệnh đến nhập viện điều trị trung bình 6,98 $\pm 2,5$ tháng.

Vị trí u: Vị trí hay găp nhất là tổn thương toàn bô hốc mắt $26,7 \%$; u ở đỉnh hốc mắt $(23,3 \%)$, ở phía trên ngoài $(20 \%)$, thấp nhất là trên trong $(6,7 \%)$.

Bảng 1: Phân bố vị trí của u hậu nhãn câu

\begin{tabular}{|c|c|c|c|c|}
\hline \multirow[b]{2}{*}{ Vị trí } & \multicolumn{3}{|c|}{ Đường mổ } & \multirow[b]{2}{*}{$\mathrm{n}, \%$} \\
\hline & $\begin{array}{l}\text { Mở nắp so- } \\
\text { trân ố mắt }\end{array}$ & $\begin{array}{l}\text { Đường ổ mắt tự } \\
\text { nhiên }\end{array}$ & $\begin{array}{l}\text { Nội soi qua } \\
\text { mũi }\end{array}$ & \\
\hline Trên trong & 2 & 0 & 0 & $2(6,7 \%)$ \\
\hline Đỉnh hốc mắt & 4 & 1 & 2 & $7(23,3 \%)$ \\
\hline Bao bọc thần kinh thị & 4 & 0 & 0 & $4(13,3 \%)$ \\
\hline Trên ngoài & 5 & 1 & 0 & $6(20 \%)$ \\
\hline Dưới trong & 2 & 0 & 1 & $3(10 \%)$ \\
\hline Toàn bộ hốc mắt & 4 & 4 & 0 & $8(26,7 \%)$ \\
\hline Tổng số & $21(70 \%)$ & $6(20 \%)$ & $3(10 \%)$ & $30(100 \%)$ \\
\hline
\end{tabular}


Bảng 2. Kêt quả giải phẫu bệnh, khả năng phẫu thuật $(n=30)$

\begin{tabular}{|c|c|c|c|c|c|}
\hline \multirow{2}{*}{\multicolumn{2}{|c|}{ Kết quả giải phẫu bênhh }} & \multicolumn{3}{|c|}{ Phấu thuật } & \multirow[b]{2}{*}{ Sinh thiết } \\
\hline & & Lây toàn & $\begin{array}{l}\text { Lấy gần } \\
\text { hết }\end{array}$ & Lấy u bán & \\
\hline \multirow{7}{*}{ Ác tính } & $\begin{array}{c}\text { Sarcoma (cơ vân thế bào thai, xơ bì lồi, } \\
\text { xương, mach, cơ vân thể hốc, sun trung mô) }\end{array}$ & 6 & 3 & 0 & 0 \\
\hline & Carcinom biếu bì nhày độ cao & 0 & 1 & 0 & 0 \\
\hline & Carcinom không sừng hóa xầm nhâp & 0 & 0 & 2 & 1 \\
\hline & Melanoma & 1 & 0 & 0 & 0 \\
\hline & Hemangiopericytome malin, độ III & 1 & 0 & 0 & 0 \\
\hline & U lympho non - Hodgkin TB B & 0 & 1 & 0 & 0 \\
\hline & K biếu mô TB đáy & 1 & 0 & 0 & 0 \\
\hline \multirow{6}{*}{$\begin{array}{l}\text { Lành } \\
\text { tính }\end{array}$} & U màng não & 3 & 4 & 0 & 0 \\
\hline & Giả u, viêm & 0 & 0 & 0 & 3 \\
\hline & Loạn sản xơ xương & 1 & 0 & 0 & 0 \\
\hline & Schwannoma & 1 & 0 & 0 & 0 \\
\hline & U mạch thế tĩnh mạch & 0 & 1 & 0 & 0 \\
\hline & Tổng & $\begin{array}{c}14 \\
(46,7 \%)\end{array}$ & $\begin{array}{c}10 \\
(33,3 \%)\end{array}$ & $\begin{array}{c}2 \\
(6,7 \%)\end{array}$ & $\begin{array}{c}4 \\
(13,3 \%)\end{array}$ \\
\hline
\end{tabular}

Kết quả ngay sau mổ (thời điểm ra viện): Tử vong $0 \%$, nhiễm trùng tại chỗ $4 \mathrm{ca}(13,33 \%)$; không có ca nào chảy máu, rò dịch não tủy, tràn khí hay mổ lại.

Bảng 3. Điều trị bổ trợ sau phẫu thuật

\begin{tabular}{|c|c|c|}
\hline $\begin{array}{c}\text { Điêuu trị bố trợ sau phâu } \\
\text { thuật }\end{array}$ & $\mathbf{n}=\mathbf{3 0}$ & $\mathbf{\%}$ \\
\hline Hóa trị & 1 & 3,4 \\
\hline Xạ trị & 7 & 23,3 \\
\hline Hóa xạ trị & 7 & 23,3 \\
\hline Không cân điều trị bố trợ & 15 & 50 \\
\hline
\end{tabular}

Kết quả khám lại: thời gian (ngắn nhất 03 tháng, dài nhất 48 tháng, trung bình 16,13 \pm 11,5 tháng); Tỷ lệ chụp CT, MRI kiểm tra ở thời điểm khám lại sau 03 tháng chiếm $100 \%$ và hiện tại chiếm 26/30 (86,7\%).
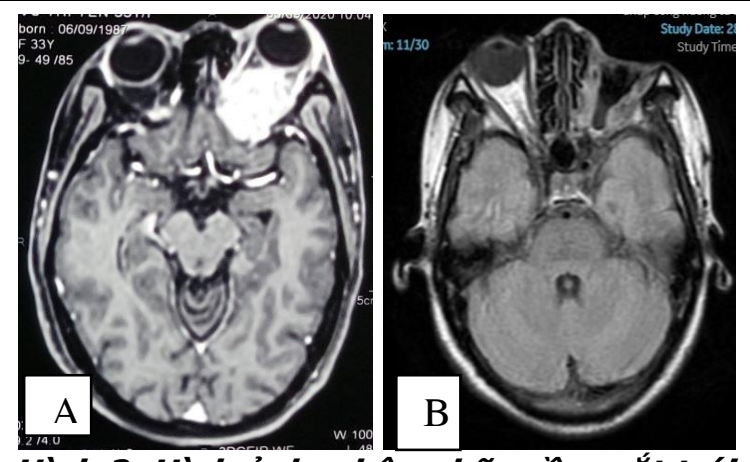

Hình 2: Hình ảnh u hậu nhãn cầu mắt trái.

(A) MRI trước mổ; (B) MRI sau mố.

Giải phẫu bệnh: U hắc tố ác tính. (Nguồn: BN VŨ $T H I$ Y.)

Bảng 4. Kêt quả khám lại-giải phẫu bệnh

\begin{tabular}{|c|c|c|c|c|c|c|}
\hline \multirow[b]{2}{*}{$\begin{array}{l}\text { Kết quả } \\
\text { khám lại }\end{array}$} & \multirow{2}{*}{\multicolumn{2}{|c|}{\begin{tabular}{|c|c|}
$\begin{array}{c}\text { Số } \\
\text { Iượng }\end{array}$ & $\begin{array}{c}\text { Tỷ lệ } \\
(\%)\end{array}$ \\
\end{tabular}}} & \multicolumn{3}{|c|}{ Thời gian (tháng) } & \multirow[b]{2}{*}{ Các loại GPB } \\
\hline & & & $\begin{array}{c}\text { Ngắn } \\
\text { nhất }\end{array}$ & nhất & $\begin{array}{c}\text { Trung } \\
\text { bình }\end{array}$ & \\
\hline Tử vong & $8 / 30$ & 26,7 & 3 & 17 & $\begin{array}{c}9,0 \pm \\
4,3\end{array}$ & $\begin{array}{l}\text { Carcinom không sừng hóa xâm nhập } \\
\text { Sarcoma (cơ vân thể hốc, xương, cơ vần thê } \\
\text { bào thai, sụn trung mồ, xơ bì lồi), Carcinom } \\
\text { biểu bì nhày độ cao. }\end{array}$ \\
\hline $\begin{array}{l}\text { U tiến triển \& } \\
\text { tái phát }\end{array}$ & $6 / 30$ & 20 & 5 & 48 & $\begin{array}{l}18,17 \\
\pm 15,5\end{array}$ & $\begin{array}{c}\text { Hemangiopericytome malin độ III, Sarcoma } \\
\text { cơ vân thể hốc, sarcoma xương, Sarcoma co } \\
\text { vân thể bào thai, Carcinom không sững hóa } \\
\text { xâm nhập, Sarcoma xơ bì lồi. }\end{array}$ \\
\hline $\begin{array}{c}\text { U tồn dư, } \\
\text { u lành tính \& } \\
\text { không tiến triển }\end{array}$ & $9 / 30$ & 30 & 3 & 45 & $\begin{array}{c}15,67 \pm \\
12,7\end{array}$ & $\begin{array}{l}\text { U màng não, loạn sản xơ xương, u mạch thê } \\
\text { tĩnh mạch, giả u - viêm mạn }\end{array}$ \\
\hline $\begin{array}{l}\text { Không còn u, u } \\
\text { lành tính }\end{array}$ & $4 / 30$ & 13,3 & 11 & 27 & $\begin{array}{c}19,25 \pm \\
8,9\end{array}$ & Swhannoma, u màng não. \\
\hline
\end{tabular}

Triệu chứng lâm sàng khi khám lại: lồi mắt 6/30 (20\%), đau hậu nhãn cầu 4/30 (13,3\%), liệt dây thần kinh vận nhãn 3/30 (10\%). 


\section{BÀN LUÂN}

Trong nghiên cứu của chúng tôi tuổi trung bình là $37,8 \pm 22,6$ tuổi $(4-71)$, không có sự khác biệt về giới. Điều này phù hợp với nghiên cứu trong và ngoài nước là u hậu nhãn cầu thường gặp ở độ tuổi trung niên và sự khác biệt ở hai giới là không lớn. Theo nghiên cứu [2], [6] u hậu nhãn cầu ở trẻ em thường gặp là u tế bào đêm của thần kinh thi, ung thư cơ vân, trong đó người lớn thường thấy u màng não, $u$ tế bào Schwann... Trong nghiên cứu của chúng tôi không có sự khác biệt về mắt bệnh học ở từng nhóm tuổi, điều này do mẩu nghiên cứu của chúng tôi chưa đủ lớn.

Dấu hiệu rất thường gặp nhất của u hậu nhãn cầu là dấu hiệu lồi mắt. Trong nghiên cứu của chúng tôi, lî̀i mắt là dấu hiệu chủ yếu ( $90 \%$ các trường hợp). Đánh giá hướng lồi, lệch của nhãn câu cho chúng ta dự đoán về bệnh học của khối u. Ví như u dây thần kinh thị thường đẩy nhãn cầu theo trục dọc ra trước. Kết quả này cao hơn với các nghiên cứu nước ngoài [1], [6]. Triệu chứng đau thường gặp ở những trương hợp u di căn, u ác tính tiến triển nhanh. Đau trong u hậu nhãn cầu thường khu trú, hằng định, đau nhiều về đêm. Những u lành tính thường ít gây đau hơn mặc dù người bệnh có thể cảm giác căng tức vùng mắt. Nghiên cứu trên cho thấy triệu chứng đau mắt xuất hiện chiếm $86,7 \%$ cao hởn các nghiên cứu [2], [6], [7]. Giảm thị lực là một triệu chứng rất quan trọng chẩn đoán phân biệt những khối u nguyên phát ảnh hưởng dây thần kinh thị. Khối u màng não hay glioma dây thần kinh thị thường gây giảm thị lực đáng kể, trong khi các khối u ngoài trục cơ vận nhãn chỉ gây ảnh hưởng thị lực khi khối u phát triển choán chỗ đủ lớn gây chèn ép thần kinh thị giác [5]. Nghiên cứu của chúng tôi, triệu chứng giảm thị lực chiếm $76,7 \%$. Các triệu chứng khác tần suất ít hơn có thể gây nên tình trạng khó chịu, ảnh hưởng chức năng cho bệnh nhân. Như: sung huyêt, sụp mi, sưng, ... do khối u gây nên [2],[6], [7].

Thời gian khởi phát bệnh đến nhập viện điều trị trung bình $6,98 \pm 2,5$ tháng. Kết quả cũng như các nghiên cứu [2 ], [6].

Vị trí khối u giúp lựa chọn đường mổ sao cho phù hợp.Trong đó, vị trí tổn thương toàn bộ hốc mắt $26,7 \%$; u ở đỉnh hốc mắt (23,3\%), ở phía trên ngoài $(20 \%)$, thấp nhất là trên trong $(6,7 \%)$. Đường kính u trên MRI trung bình là $35,1 \pm 13,6 \mathrm{~mm}$; kích thước lớn nhất 7,8cm nằm ở vị trí hậu nhãn cầu nên gây ra nhiều triệu chứng, khó khăn về phẫu thuật, nhất là chọn lựa đường mổ. Việc đánh giá cấu trúc khối u trền chẩn đoán hình ảnh, tiên lượng giải phẫu bệnh giúp chúng tôi đưa ra cách thức mổ.. Nghiên cứu này cao hơn so các nghiên cứu của các tác giả trên thế giới[2], [7].

Các đường mổ để tiếp cận khối u hậu nhãn cầu đã được nhiều tác giả trên thế giới báo cáo [1], [2], [5], [6]. Tai khoa Ngoại thần kinh bệnh viện $\mathrm{K}$, áp dụng phẩu thuật $\mathrm{u}$ hậu nhãn cầu gồm ba đường: đường mở nắp sọ trần ổ mắt, đường trực tiếp qua ổ mắt tự nhiên và mổ nội soi qua mũi để tiếp cận tổn thương thành trong hốc mắt. Một số trường hợp có thể phối hợp các đường mổ trên. Chọn lựa đường mổ được làm chủ yếu dựa trên vị trí, loại tổn thương, mức độ lan tỏa của u cũng như mục đích của phẫu thuật. Kết quả nghiên cứu này cho thấy: đường mở nắp sọ trần ổ mắt chiếm tỉ lệ cao nhất $70 \%$, tiếp theo là đường trực tiếp vào ổ mắt tự nhiên $20 \%$, đường mổ nội soi qua mũi để tiếp cận tổn thương thành trong hốc mắt $10 \%$. Đường mổ mở nắp sọ trần ồ mắt được ứng dụng rộng rãi nhất là với u vị trí khó đỉnh hốc mắt, xâm lấn nền sọ. Kết quả này phù hợp với các nghiên cứu [4], [6], [7].

Trong nghiên cứu của chúng tôi: các khối u màng não, sarcoma cơ vân thể bào thai, carcinom không sừng hóa xâm nhập là những u gặp nhiều nhất, chiếm tỉ lệ lần lượt là $23,3 \%$; $13,3 \% ; 10 \%$. Kết quả này cũng phù hợp với các nghiên cứu y học trên thế giới [2], [6]. Kết quả giải phẫu bệnh ở nhóm u khác do số lượng còn giới hạn, đa dạng về giải phẫu bệnh nển chưa cho phép nhận định về mối liên quan giải phẫu bệnh với các biến số lâm sàng khác. Tuy nhiên, ở trẻ em thường gặp nhất là glioma thần kinh thị, sarcoma cơ vân thể bào thai. Các u di căn hốc mắt, u màng não, u mạch,... thường gặp ở người lớn [6].

Điều trị u hậu nhãn cầu là điều trị đa mô thức bao gồm: phẫu thuật, xa trị, hóa chất, điều trị miễn dịch. Phẫu thuật vẫn là một phương pháp điều trị cơ bản nhằm lấy u tối đa và xác định chính xác độ mô học của khối u để đưa ra các chỉ định điều trị bổ trợ sao cho phù hợp. Trong một số trường hợp khi u ở những vị trí chức năng quan trọng không thể lấy hết u thì phẫu thuật mục tiêu của phẩu thuật là lấy bỏ tối đa nhằm tăng hiệu quả của các phương pháp điều trị bổ trợ tiếp sau.Trong nghiên cứu của chúng tôi, tỷ lệ phẫu thuật lấy hết u chiếm $46,7 \%$, lấy gần hết u $33,3 \%$, sinh thiết và giải ép chiếm $13,3 \%$, lấy một phần u chiếm $6,7 \%$. Tỷ lệ phẫu thuật lấy hết u thấp hơn trong khi lấy một phần u cao hơn so với nghiên cứu Margalit N (2007) [4], phẫu thuật lấy hết u và gần hết u cao hơn 
so nghiên cứu Park H] [5]. Phẫu thuật lấy một phần u là những trường hợp u xâm lấn vào những vùng chức năng quan trọng như dây thần kinh thị, động mạch mắt, nền sọ..., u có ranh giới không rõ ràng, nếu cố gắng lấy hết u sẽ gây thiếu hụt thần kinh nghiêm trọng, tử vong [6], [7].

Các biến chứng gặp nhiều nhất sau phẩu thuật là nhiễm trùng tại chỗ ( 4 ca mổ khoét bỏ nhãn cầu và lấy u) với tỷ lệ là 13,33\% đã được làm sạch rửa vết mổ tại chổ hốc mắt, điều trị nội khoa ổn định. Không có ca nào chảy máu, rò dịch não tủy, tràn khí hay mổ lại. Di chứng như sụp mi, liệt vận nhãn là triệu chứng hay gặp chiếm tỉ lệ lần lượt $10 \%$. Vì vậy, cần hiểu rõ về mặt hình ảnh học, cấu trúc giải phẫu, tiên lượng trước mổ và ứng dụng kính vi phẫu, hệ thống định vị, dao Cusa trong mổ giúp giảm các biến chứng, di chứng sau mổ. Có 3 trường hợp để lại di chứng trên do khối u to xâm lấn gây chèn ép lâu ngày. Những trường hợp sụp mi do cơ nâng mi trên bị vén trong quá trình phẫu thuật thường bệnh nhân sẽ hồi phục sau 3-6 tuần sau mổ. Có 07 trường hợp mất thị lực $(23,3 \%)$ trong đó 06 bệnh nhân có chỉ định khoét bỏ nhãn cầu, 01 bệnh nhân mất thị lực do u gây ra từ trước mổ. Các biến chứng và di chứng trong nghiên cứu thấp hơn so các nghiên cứu trên thế giới [4], [6],[7].

Thời gian khám lại ngắn nhất 03 tháng, dài nhất 48 tháng, trung bình $16,13 \pm 11,5$ tháng; Tỷ lệ chụp CT, MRI kiểm tra ở thời điểm khám lại sau 03 tháng chiếm $100 \%$ và hiện tại chiếm $26 / 30(86,7 \%)$. Trong đó, $8 / 30(26,7)$ bệnh nhân đã mất tập trung ở nhóm carcinoma do bệnh lý nguyên phát kết hợp và sarcoma, không điều trị bổ trợ hoặc điều trị không đủ liều xa hóa chất, thời gian sống ngắn nhất 3 tháng và dài nhất là 17 tháng. Nghiên cứu của chúng tôi cao hơn nghiên cứu Margalit N (2007) chiếm 2/41( $4,9 \%$ ) [4] và thấp hơn Markowski $](2014)$ 29,5\% [7]. U tồn dư, u lành tính, không tiến triển và không còn $u$, u lành tính lần lượt chiếm $30 \%$ và $13,3 \%$ tập trung ở nhóm u lành. Kết quả cao hơn nghiên cứu Markowski J (2014) [7]. U tiến triển, tái phát của chúng tôi có $6 / 30(20 \%)$ cao hơn Abuzayed $\mathrm{B}(2012)$ chiếm $15.2 \%$ [6], thấp hơn Markowski J(2014) 29,5\%[7]. Đặc biệt, có 01 trường hợp $(3,3 \%)$ là hình ảnh giả u do viêm mạn không đặc hiệu vô căn ở hốc mắt chúng tôi đã tiến hành phẫu thuật sinh thiết và giải ép lỗ thị,điều trị bởi corticoid nhưng những trường hợp này cần phân biệt bệnh lý lymphoma, tỷ lệ trển thấp hơn so nghiên cứu khác [2]. Nghiên cứu chúng tôi, có $15 / 30$ (50\%) không điều trị bổ trợ sau mổ, $7 / 30(23,3 \%)$ hóa xạ trị đồng thời và $7 / 30(23,3 \%)$ xạ trị. Như vậy việc láy u tối đa, đặc biệt $u$ ác tính giúp làm giảm kích thước khối u, làm giảm thể tích khối choán chỗ, tạo điều kiện thuận lợi cho điều trị tiếp theo (hóa trị, xạ trị). Tuy nhiên có 1 trường hợp u ác tính lymphoma $(3,4 \%)$ chỉ cần sinh thiết và điều trị bổ trợ hóa chất mục đích tăng hiệu quả tiêu diệt tế bào $u$, giảm thể tích khối u, giảm triệu chứng cơ năng, tăng chất lượng cuộc sống, tăng thời gian sống[2],[6],[7].

\section{KẾT LUẬN}

Tỷ lệ nam/nữ là 1,14/1; tuổi trung bình là $37,8 \pm 22,6$ (4 - 71 tuối). Triệu chứng lâm sàng thường hay gặp nhất là lî̀i mắt $(90 \%)$, đau mắt $(86,7 \%)$, giảm thị lực $(76,7 \%)$. Khối u lành tính $(43,4 \%)$, u ác tính $(56,7 \%)$; trong đó hay gặp nhất là u màng não $(23,3 \%)$, sarcoma cơ vần thể bào thai $(13,3 \%)$, carcinoma không sừng hóa xâm nhập $(10 \%)$. Kết quả lấy toàn bộ u và gần hết u là 46,7\% và 33,3\%. Không có trường hợp nào tử vong, chảy máu do phẫu thuật.

Kết quả khám lại hiện tại: Có $8 / 30$ (26,7\%) bệnh nhân tử vong, trung bình $9,0 \pm 4,3$ tháng, các loại giải phẫu bệnh (Carcinom không sừng hóa xâm nhập; Sarcoma (cơ vân thể hốc, xương, cơ vân thể bào thai, sụn trung mô, xơ bì lồi); Carcinom biểu bì nhày độ cao)). U tiến triển, tái phát: có $6 / 30(20 \%)$, trung bình $9,0 \pm 4,3$ tháng, các loại giải phẫu bệnh (Hemangiopericytome malin độ III, Sarcoma (cơ vân thể hốc, xương, cơ vân thể bào thai, xơ bì lồi), Carcinom không sừng hóa xâm nhập). Còn u tồn dư, u lành tính, không tiến triển: có $9 / 30$ (30\%), trung bình $15,67 \pm 12,7$ tháng, các loại giải phẫu bệnh (u màng não, loạn sản xơ xương, u mạch thể tĩnh mạch, giả u - viêm mạn). Không còn u, u lành tính: có $4 / 30(13,3 \%)$, trung bình $19,25 \pm 8,9$ tháng, các loại giải phấu bệnh (Swhannoma, u màng não).

\section{TÀI LIẸU THAM KHẢO}

1. Huỳnh Lê Phương (2012), "U hậu nhãn câu: Kinh nghiệm chẩn đoán và điếu trị phấu thuật". Y Học Thành́ Phố Hồ Chí Minh, 16(4), 273-281.

2. Darsaut TE, et al., (2001) Introductory overview of orbital tumorsNeurosurg Focus 10(5):1-9.

3. Ohtsuka K, et al., (2005) A review of 244 orbital tumors in Japanes patients during a 21 year period: origins and locations: Jpn Ophthalmol 49:49-55.

4. Margalit N, Ezer H, Fliss DM, Naftaliev E, Nossek E, Kesler Á (2007), "Orbital tumors treated using transcranial approaches: surgical technique and neuroophthalmogical results in 41 patients". Neurosurg Focus, 23(5), E11.

5. Park HJ, Yang SH, Kim IS, Sung JH (2008), " 
Surgical treatment of orbital tumors at a single institution". J Korean Neurosurg Soc, 44, 146- 150.

6. Abuzayed B, Kucukyuruk B, Tanriover N, Sanus GZ, Canbaz B, Akar Z, et al. (2012), "Transcranial superior orbitotomy for the treatment of intraorbital intraconal tumors: surgical technique and long-term results in single institute". Neurosurg Rev, 35(4), 573-582.

7. Markowski J, Jagosz-Kandziora E, Likus W, Pajak J, MrukwaKominek E, Paluch J, et al.
(2014), "Primary orbital tumors: a review of 122 cases during a 23-year period: a histo-clinical study in material from the ENT Department of the Medical University of Silesia". Med Sci Monit, 20, 988-994.

8. Boari N, Gagliardi F, Castellazzi P, Mortini P (2011), "Surgical treatment of orbital cavernomas: clinical and functional outcome in a series of 20 patients". Acta Neurochir (Wien), $153(3), 491-498$

\title{
KẾT HỢP NÚT TĨNH MACH CỬA VÀ TĨNH MACH GAN LÀM PHÌ ĐẠI GAN TRƯỚC PHẪU THUÂTT CẮT GAN LỚN: BÁO CÁO TRƯờNG HỢP
}

\author{
Lê Thanh Dũng ${ }^{1}$, Thân Văn Sỹ ${ }^{1}$, Ninh Viết Khải \\ Đào Xuân Hải ${ }^{1}$, Nguyễn Quang Nghĩa ${ }^{2}$
}

\section{TÓM TẮT}

Nút mạch đồng thời tĩnh mạch cửa và tĩnh mạch gan (LVD) được áp dụng rộng rãi trong thời gian gần đây do làm tắng đáng kể tốc độ và mức độ phì đại gan trước phấu thuât cắt gan lớn so với phướng pháp nút tĩnh mạch cửa (PVE) đơnn thuần, từ đó rút ngắn được thời gian chờ đợi phẫu thuật và giảm nguy cơ khổi u tiến triển. Chúng tôi báo cáo một trượng hợp được thực hiện LVD làm phì đại gan trước phẫu thuật cắt gan lớn do khối ung thư đường mật trong gan. Sau thủ thuật, bệnh nhân có tăng đáng kể thể tích gan còn lại theo dự kiến trong vòng 3 tuần. Phẫu thuật cắt gan phải mở rộng sau thời điểm nút mạch 4 tuần mà không có biến chứng suy gan sau phẫu thuât. Qua trường hợp lâm sàng này, chúng tôi nhận thấy LVD có hiệu quả cao trong việc làm tăng thể tích gan còn lại theo dự kiến (FLR) trước phẫu thuật cắt gan lớn.

Tư khoá: Nút tĩnh mạch cửa, nút tĩnh mạch gan, phẫu thuật cắt gan lớn, ung thư đường mật.

\section{SUMMARY}

SIMULTANEOUS PORTAL AND HEPATIC

\section{VEIN EMBOLIZATION BEFORE MAJOR}

LIVER RESECTION: A CASE REPORT

Simultaneous portal hepatic vein embolization (LVD) has been widely applied in recent years because of significantly increasing the rate and degree of liver hypertrophy in comparison with portal venous embolization (PVE) before major hepatectomy. So that, LVD brings the shortening waiting time for surgery and reducing the risk of tumor progression. We report a case where LVD was performed before major hepatectomy due to intrahepatic cholangiocarcinoma. The patient then had a significant

\footnotetext{
${ }^{1}$ Bệnh viện Hữu nghi Việt Đức

${ }^{2}$ Trung tâm Ghép Tạng - Bệnh viện Hữu nghị Việt Đức Chiu trách nhiệm chính: Thân Văn Sỹ

Email: sy.hmu0915@gmail.com

Ngày nhận bài: 10.8.2021

Ngày phản biện khoa học: 5.10 .2021

Ngày duyệt bài: 14.10.2021
}

increase in the future liver remnant (FLR) after 3 weeks. Major liver resection then was performed at 4 weeks after LVD without postoperative liver failure. From this clinical case, we found that LVD was highly effective in increasing FLR before major hepatectomy. This procedure could be a great alternative to PVE, especially in case of small initial FLR.

Keywords: Portal vein embolization, hepatic vein embolization, major liver resection, cholangiocarcinoma.

\section{I. ĐĂT VẤN ĐỀ}

Phẫu thuât cắt gan cho tới nay vẫn là phương pháp điều trị chính đối với các tổn thương ác tính tại gan. Nhược điểm chính của phương pháp này là nguy cơ suy gan sau phẫu thuật, đặc biệt ở những trường hợp cân cắt gan lớn mà thể tích gan không đủ [1]. Nút tĩnh mạch cửa (portal venous embolization - PVE) gây phì đại gan là kỹ thuật đã được áp dụng trên toàn thế giới từ nhiểu năm nay, góp phân mở rông chỉ định cắt gan và cải thiện kết quả sau phẫu thuâtt [2]. Mắc dù vậy, thủ thuật này đòi hỏi thời gian chờ đợi tương đối dài, thường phải sau 6 - 8 tuân. Hơn nữa, theo các báo cáo, có tới 30\% trường hợp bênh nhân sau PVE không thể phẫu thuât vì tăng thể tích gan còn lại theo dự kiến (future liver remnant - FLR) không đủ hoăc do khối u tiến triển [2].

Gần đây, trên thế giới đã và đang áp dụng phương pháp nút đồng thời tĩnh mạch cửa và tĩnh mạch gan (liver venous deprivation - LVD) thay thế cho PVE, cho thấy an toàn và tăng hiêu quả đáng kể về khả năng phì đai gan so với PVE [3], [4], [5]. Chúng tôi trình bày trường hợp lâm sàng được thực hiện nút đồng thời tĩnh mạch cửa và tĩnh mach gan nhằm mục đích gây phì đại gan trước phẩu thuât cắt gan lớn cùng một số tổng kết từ y văn. 


\section{PHƯƠNG PHÁP NGHIÊN CỨU}

Phương pháp mô tả ca lâm sàng tại Bênh viện Hữu nghị Việt Đức tháng 6 năm 2020, và tổng kết y văn về áp dụng LVD để làm phì đại gan trước phẫu thuật cắt gan lớn.

\section{CA LÂM SÀNG}

Bệnh nhân nam 57 tuổi, tiền sử viêm gan $B$ mạn tính. Siêu âm phát hiện đám tổn thương giảm âm gan phải kích thước $55 \mathrm{~mm}$ khi đi kiểm tra sức khoẻ định kỳ. Cắt lớp vi tính ngực - bụng - tiểu khung được chỉ định, cho thấy khối tổn thương kích thước $55 \times 61 \mathrm{~mm}$, nằm ở hạ phân thuỳ VII-VIII, xâm lấn tĩnh mạch gan giữa và lan một phần sang hạ phân thuỳ IV (Hình 1). Tổn thương ngấm thuốc kém thì động mạch, tĩnh mạch, ngấm nhiều hơn ở thì muộn. Bờ của tổn thương không đều, ranh giới không rõ, kèm co kéo bao gan lân cận. Ngoài ra còn một số nốt vệ tinh nhỏ nằm rải rác trong HPT VII-VIII. Các đặc điểm này phù hợp với hình ảnh của ung thư đường mật trong gan. Xét nghiệm máu cho thấy alphaFP $5,5 \mathrm{ng} / \mathrm{ml}$, CEA $1,7 \mathrm{ng} / \mathrm{ml}$, CA $19-978$ UI/L, AST 31U/L, ALT 25U/L, Bilirubin toàn phần 31.4 umol/l, bilirubin trực tiếp 7.3 umol/l, tiểu cầu 147, prothrombin $87 \%$. Kết quả sinh thiết khối u gan khẳng định ung thư đường mật trong gan. Bệnh nhân được chỉ định phẩu thuật cắt gan phải mở rộng (lấy bỏ toàn bộ gan phải và HPT IV), tuy nhiên thể tích gan HPT I+II+III, phần còn lại dự kiến (Future liver remnant - FLR), là $397 \mathrm{ml}$, chiếm < 0,5\% tổng trọng lượng cơ thể, không đảm bảo duy trì chức nằng gan sau phẫu thuật. Sau khi hội chẩn đa chuyên khoa, thủ thuật nút tĩnh mạch cửa kết hợp nút tĩnh mạch gan được thực hiện nhằm mục đích tăng FLR và rút ngắn thời gian chờ đợi phẫu thuật nhất có thể. Tĩnh mạch cửa phải được nút tắc bằng 01 Amplatzer vascular Plug I $8 \times 14 \mathrm{~mm}$ và hỗn hợp của NBCA và Lipiodol (tỷ lệ 1:4). Tĩnh mạch gan phải tiếp đó được nút tắc bởi 01 Amplatzer Vascular Plug II $18 \times 20 \mathrm{~mm}$. Sau thủ thuật bênh nhân ổn định, không có bất kỳ biến chứng đáng kể nào liên quan đến thủ thuật. Cắt lớp vi tính ổ bụng được thực hiện sau đó 3 tuần cho thấy khối u đường mật ổn định, thể tích gan phân thuỳ bên (HPT I+II+III) đo được $608 \mathrm{ml}$ (Hình 2). Với FLR tăng lên đáng kể sau phẫu nút mạch (chiếm 0,8\% tổng trọng lượng cơ thể), phẫu thuật cắt gan phải mở rộng (bao gồm toàn bộ gan phải và một phần HPT IV) được thực hiện sau đó 1 tuần. Sau phẫu thuật, không có tình trạng suy gan trên lâm sàng và xét nghiệm, cũng như bất kỳ biến chứng đáng kể nào khác được nghi nhận. Bệnh nhân hồi phục tốt và được xuất viện sau 15 ngày.

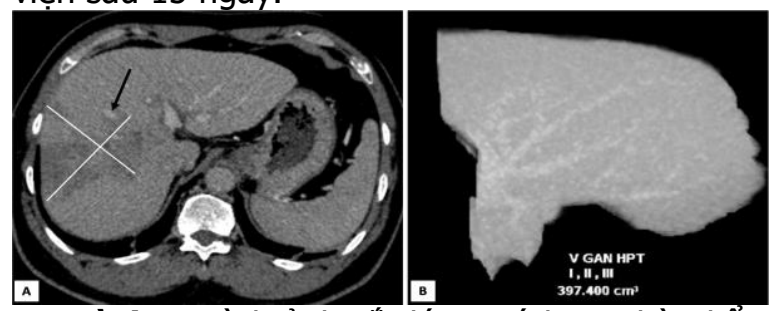

Hinh 1: Hình ảnh cắt lớp vi tính tại thời điểm trước nút mạch. Khối u gan ngấm thuốc kém nằm ở hạ phân thuỳ VII-VII, xâm lấn tĩnh mạch gan giữa (mũi tên đen) và một phần hạ phân thuỳ IV $(A)$. Thể tích gan còn lại dự kiến gồm hạ phân thuỳ I+II+III đo được 397ml.

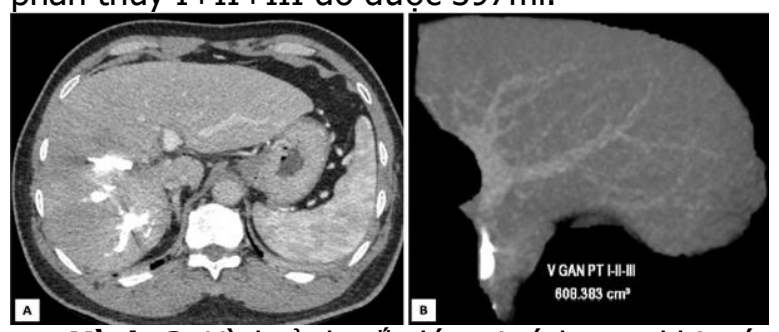

Hình 2: Hình ảnh cắt lớp vi tính sau khi nút tĩnh mạch cửa và tĩnh mạch gan 3 tuần. Gan thay đổi hình thái: giảm thể tích gan phải, tăng thể tích gan trái $(A)$. Thể tích gan còn lại dự kiến gồm hạ phân thuỳ I+II+III đo được 608 ml.

\section{BÀN LUẬN}

Ung thư đường mật là bệnh lý ác tính nguyên phát phổ biến thứ 2 tại gan sau ung thư tế bào gan nguyên phát. Cho tới nay, mặc dù nhiều phương pháp điều trị mới cùng với các thế hệ thuốc chống ung thư mới ra đời, phẫu thuật vẫn là phương pháp điều trị chính và có hiệu quả nhất đối với ung thư đường mật trong gan. Trường hợp bệnh nhân của chúng tôi, khối ung thư đường mật gan phải với kích thước lớn và lan sang tới cả HPT IV. Do FLR còn lại quá nhỏ không thể tiến hành phẫu thuật ngay, thủ thuật nút tînh mạch gây phì đại gan trước phẫu thuật là cần thiết để tránh biến chứng suy gan sau mổ.

Với mục đích làm phì đại gan trước phẫu thuật, phương pháp nút đồng thời tĩnh mạch cửa và tĩnh mạch gan được áp dụng trong những năm gần đây để thay thế cho nút tĩnh mạch cửa đơn thuần do có độ an toàn tương đương trong khi có mức độ phì đại gan nhiều hơn và thời gian chờ đợi phẫu thuật ngắn hơn. Le Roy và cộng sự so sánh 31 bệnh nhân được thực hiện kỹ thuật nút tĩnh mạch kép và 41 bệnh nhân được nút PVE đơn thuần, không có biến chứng nặng liên quan đến quá trình can thiệp. Nhiều nghiên cứu 
khác cũng cho kết quả tương tự [5], [6]. Cũng phải nhắc lại rằng, cho tới nay, nhiêu phương pháp gây phì đại gan đã được áp dụng ( $P V E$, PVE kết hợp nút động mạch gan, LVD, phẫu thuật thắt tĩnh mạch cửa phải kết hợp phân tách nhu mô gan hai thuỳ và cắt gan thì hai (ALPPS)...) tuỳ thuộc vào mức độ phì đại gan cần thiết, tình trạng của nhu mô gan cũng như chiến lược phẫu thuật của từng trường hợp cụ thể [7], [8]. Chung quy lại, các thủ thuật can thiệp điện quang (PVE và LVD) ít xâm lấn hơn mặc dù có hiệu quả phì đại gan thấp hơn so với các can thiệp ngoại khoa (ALPPS). ALPPS được báo cáo lần đầu năm 2011, cho thấy có tốc độ phì đại FLR rất nhanh chóng (74\% trong 9 ngày) [7]. Tuy nhiên, tỷ lệ các biến chứng lớn còn ở mức cao và tỷ lệ tử vong lên đến $12 \%$ [7]. Do đó, LVD đã và đang được áp dụng ngày càng rộng rãi hơn [3].

Trường hợp lâm sàng của chúng tôi cho thấy, FRL sau 3 tuần tăng $53,1 \%$ so với trước can thiệp $(608 \mathrm{ml}$ so với $397 \mathrm{ml})$. Kết quả này khá tương đồng với kết quả của các nghiên cứu khác [3]. Trong nghiên cứu của Le Roy B. và cộng sự thực hiện trên 72 bệnh nhân cho thây tỷ lệ tăng FLR sau 3 tuần lần lượt là $51,2 \%$ và $31,9 \%(p=$ 0,018 ) của nhóm LVD và PVE [6]. Tương tự, nghiên cứu của Laurent $C$. và cộng sự cũng cho thấy tỷ lệ phì đại FLR sau 4 tuần của nhóm LVD và PVE lần lượt là $61.18 \%$ và $28.98 \%$ [6]. Cơ chế liên quan đến sự tăng mức độ phì đại gan sau LVD so với PVE có lẽ do sự tăng áp lực tĩnh mach cửa của vùng gan dự kiến không cắt bỏ. Nút tắc tĩnh mạch cửa làm giảm đáng kể lưu lượng dòng máu tại thuỳ gian dự kiến cắt bỏ và làm tăng lưu lượng máu tại thuỳ gan bên đối diện [8]. Điều này dẫn đến giải phóng các chất kích thích tân taao gan ở thùy gan không nút mạch. Cơ chế này được biết đến là "phản ứng đệm động mạch gan" (hepatic arterial buffer response), gây phì đại gan qua cơ chế thiếu oxy [8].

Rõ ràng là thời gian chờ đợi sau nút mạch và mức độ phì đại gan ảnh hưởng rất lớn đển khả năng phâu thuật của bệnh nhân. Theo các báo cáo trước đây, phương pháp PVE thường có thời gian chờ đợi dài, khoảng 6-8 tuần cho tới khi đủ tăng đủ FLR. Trong khi đó, có đến 30 - 35\% số bênh nhân sau PVE không thể tiến hành phẫu thuật do tăng thể tích gan không đủ hoặc do khối u tiến triển [9]. Trong nghiên cứu của Kobayashi $K$. và cộng sự, tỷ lẹ bệnh nhân được phẫu thuât ở nhóm PVE và LVD lần lượt là $76,9 \%$ và $95,2 \%$ [4]. Le Roy $B$. và cộng sự báo cáo tỷ lệ phẫu thuật là $76 \%$ và $81 \%$ ở nhóm PVE và LVD [3]. Như vậy các nghiên cứu đều cho thấy LVD giúp làm tăng tỷ lệ phầu thuật so với PVE.

Khi so sánh về độ an toàn giữa $L V D$ và $P V E$, các nghiên cứu gần đây đều cho thây LVD có tỷ lệ biến chứng và tử vong không khác biệt so với PVE [3], [4].

Đây là trường hợp đầu tiên chúng tôi áp dụng kỹ thuật LVD thay thế cho PVE trong việc gây phì đại gan trước phẩu thuật cắt gan lớn cho thấy kỹ thuật này có thể thực hiện tại Việt Nam, với ưu việt về mức độ cũng như tốc độ phì đại gan so với PVE. Những nghiên cứu với số lượng lớn hơn, có so sánh ngẫu nhiên cần được thực hiện đế đánh giá chính xác độ an toàn và hiệu quả của phương pháp này.

\section{KẾT LUÂN}

Qua trường hợp lâm sàng này chúng tôi nhận thấy LVD là thủ thuật an toàn và hoàn toàn có thể thực hiện được tại Việt Nam. LVD kỳ vọng mang lại hiệu quả cao trong việc gây phì đại gan trước khi cắt gan lớn, có lẽ sẽ là một lựa chọn thay thế ưu việt hơn so với kỹ thuật PVE truyền thống.

\section{TÀI LIÊU THAM KHẢO}

1. Rahbari N.N., Garden O.J., Padbury R. và công sứ. (2011). Posthepatectomy liver failure: a definition and grading by the International Study Group of Liver Surgery (ISGLS). Surgery, 149(5), 713-724.

2. Van Lienden K.P., Van Den Esschert J.W., De Graaf W. và cộng sự. (2013). Portal vein embolization before liver resection: a systematic review. Cardiovascular and interventional radiology, 36(1), 25-34.

3. Le Roy B., Gallon A., Cauchy F. và cộng sự. (2020). Combined biembolization induces higher hypertrophy than portal vein embolization before major liver resection. HPB, 22(2), 298-305.

4. Kobayashi K., Yamaguchi T., Denys A. và cộng sứ. (2020). Liver venous deprivation compared to portal vein embolization to induce hypertrophy of the future liver remnant before major hepatectomy: A single center experience. Surgery, 167(6), 917-923.

5. Guiu B., Quenet F., Escal L. và cộng sự. (2017). Extended liver venous deprivation before major hepatectomy induces marked and very rapid increase in future liver remnant function. European radiology, 27(8), 3343-3352.

6. Laurent C., Fernandez B., Marichez A. và cộng sự. (2020). Radiological simultaneous portohepatic vein embolization (RASPE) before major hepatectomy: a better way to optimize liver hypertrophy compared to portal vein embolization. Annals of Surgery, 272(2), 199-205.

7. Schnitzbauer A.A., Lang S.A., Goessmann H. và công sứ. (2012). Right portal vein ligation combined with in situ splitting induces rapid left lateral liver lobe hypertrophy enabling 2-staged 
extended right hepatic resection in small-for-size settings. Annals of surgery, 255(3), 405-414.

8. Le Roy B., Dupré A., Gallon A. và công sự. (2018). Liver hypertrophy: Underlying mechanisms and promoting procedures before major hepatectomy. Journal of visceral surgery, 155(5), 393-401.

9. Lê Thanh Dũng (2018), Nghiên cứu áp dụng và đánh giá hiệu quả của phương pháp nút nhánh tĩnh mạch cửa gây phì đại gan trước phẩu thuật cắt gan, Luận án Tiến sĩ Y học, Đại học Y Hà Nội.

\section{ĐÁNH GIÁ Độ CHÍNH XÁC VÀ AN TOÀN CỦA KỸ THUÂT TIÊM NGOÀI MÀNG CỨNG CộT SỐNG THẮT LƯNG DƯỚI HƯỚNG DẪN CỦA SIÊU ÂM}

\section{TÓM TẮT}

Mục tiêu: bước đầu đánh giá độ chính xác và an toàn của phương pháp tiêm steroid ngoài màng cứng qua lỗ liên hợp bằng cách xác thực dưới $x$ quang. Phương pháp: nghiên cứu mô tả 15 người bênh, đau kiểu rễ thần kinh do thoát vị đĩa đệm cột sống thắt lưng, được tiến hành tiêm steroid ngoài màng cứng qua lỗ liển hợp với kim được dẫn đường dưới hướng dẫn của siêu âm trên bình diện cắt ngang của cột sống và được xác thực bằng chụp x quang. Kết quả: độ chính xác của can thiệp dưới hướng dân của siêu âm là 86,7\% được xác thực bởi chụp x quang. Có 02 trường hợp không chính xác: 01trường hợp sai tâng và 01 trường hợp đúng tầng nhưng kim ở ngoài lố liên hợp. Không có biến chứng nào được ghi nhận. Kết luận: Tiêm ngoài màng cứng qua lố liên hợp là chính xác và có thế thực hiện trong lâm sàng với độ chính xác bước đâuu là $86,7 \%$ và không có biến chứng.

Tư khóa: Tiêm ngoài màng cứng, đau thắt lưng, đau kiểu rễ thần kinh, thoát vị đĩa đệm, siêu âm

\section{SUMMARY}

\section{THE ACCURACY AND SAFETY OF ULTRASOUND - GUIDED LUMBAR TRANSFORAMINAL EPIDURAL INJECTION}

Objective: To investigate the accuracy and safety rate (technical precision) of ultrasound-guided lumbar transforaminal epidural steroid injection, which was validated by conventional fluoroscopic technique. Methods: A total of 15 patients with unilateral singlelevel lumbar foraminal disc protrusion causing radiculopathy were enrolled. Using transforming route, the needle location was determined by an axial (transvers) view of the ultrasound with fluoroscopic confirmation. Results: The accuracy of ultrasoundguided interventions was $86,7 \%$ as confirmed by fluoroscopy. There were 02 failed cases in the USguided: 01 case were wrong level and 01 case was right level but in extraforaminal. No complications

*Bệnh viện HN Việt Đức

Chịu trách nhiệm chính: Nguyễn Hoàng Long

Email: longnguyen.drspine@gmail.com

Ngày nhận bài: 5.8.2021

Ngày phản biên khoa họ: 5.10 .2021

Ngày duyệt bài: 14.10.2021

\section{Nguyễn Hoàng Long*, Vũ Văn CườngB*, Nguyễn Duy Linh*, Lê Đức Anh*}

were noted. Conclusion: Ultrasound-guided lumbar transforaminal epidural injections are accurate and feasible in clinical setting with an accuracy of $86,7 \%$ and no complications.

Key word: Epidural injection, low back pain, radiculopathy, disc herniation, ultrasound

\section{I. ĐẶT VẤN ĐỀ}

Đau kiểu rễ thần kinh cột sống thắt lưng thường do nguyên nhân chèn ép hoặc kích thích các rễ thân kinh tương ứng trong ống sông hoặc trên đường đi của rễ. Các phương pháp điêuu trị từ bảo tôn cho tới phẫu thuật.Phong bế ngoài màng cứng (NMC) qua lỗ liên hợp là thủ thuật hay được dùng điều trị đau lan kiểu rễ thân kinh do nguyên nhân từ cột sống[1]. Thông thường thủ thuật này sẽ được thực hiện dưới hướng dẫn của X-quang hoặc cắt lớp vi tính vì có thể quan sát đâu mũi kim và sự lan thuốc cản quang. Tuy nhiên, nhược điểm chính của thủ thuật này là nguy cơ nhiễm tia chongười bệnh(NB), bác sĩ và các nhân viên y tế khác, yêu cầu có khu vực đặc biệt (buông có bọc chì, tấm chắn tia $X$, bàn làm thủ thuật cần thấu quang...) để thực hiện những thủ thuật này, trang thiết bị đắt tiền, mặc đồ bảo hộ nặng, nóng và không thoải mái.Trong vài năm gần đây, tiêm phong bế thần kinh dưới hướng dẫn của siêu âm được áp dụng cho thấyđã khắc phục được những nhược điểm nói trên của phương pháp phong bế dưới hướng dẫn của $x$ quang và cắt lớp vi tính. Mặc dù siêu âm được chứng minh là an toàn và khả thi đối với tiêm cột sống như tiêm phong bế rễ thân kinh, phong bế nhánh trong, và tiêm diện khớp, nhưng đối với phương pháp tiêm NMC qua lỗ liên hợp vẫn còn những thách thức vì bóng cản của các cấu trúc xương ở khu vực lỗ liên hợpvì vậy gây khó khăn cho sự quan sát đâu kim ở vị trí này.

Ở Việt Nam, phương pháp tiêm NMC qua lỗ liên hợp dưới hướng dấn của $X$ quang đã được tiến hành ở một số trung tâm như bệnh viện HN Việt Đức, bệnh viện trung ương Đà Nẵng ... Còn 
phương pháp gây tê NMC qua lỗ liên hợp dưới hướng dân của siêu âm tuy đã có một số trung tâm ứng dụng phương pháp này trong thực hành lâm sàng, tuy nhiên chưa có báo cáo cho thây tính chính xác và an toàn của phương pháp.

\section{II. ĐỐI TƯợNG VÀ PHƯƠNG PHÁP NGHIÊN CứU}

2.1 Đối tượng nghiên cứu: Người bệnh được chẩn đoán đau kiểu rễ do thoát vị đĩa đêm/phình đĩa đêm cột sống thắt lưng, được chỉ định tiêm ngoài màng cứng tại khoa Phẫu thuật cột sống bệnh viện HN Việt Đức từ tháng 5/2021 đến tháng 8/2021, thỏa mãn tiêu chuẩn nghiên cứu.

Tiêu chuẩn lựa chọn người bệnh: Người bệnh được chẩn đoán thoát vị đĩa đệm cột sống thắt lưng với triệu chứng đau lan kiểu rễ dây thần kinh tương ứng với thoát vị được xác định trên phim chụp cộng hưởng từ. NB đã được điều trị thuốc và phục hồi chức năng ít nhất 3 tháng trở lên mà triêu chứng không cải thiện.

\section{Tiêu chuẩn loai trừ:}

- NB thoát vị đĩa đệm kèm biểu hiện liệt vận động rễ thần kinh tương ứng

- NB thoát vị đĩa đệm kèm rối loạn cảm giác vùng tầng sinh môn hoặc/và rối loạn đại tiểu tiện

- Nhiếm trùng, lao cột sống

- Dị ứng các thành phần thuốc: thuốc cản quang, betamethasone, lidocaine

- Từ chối tham gia nghiên cứu

Thời gian và địa điểm nghiên cứu. Nghiên cứu được thực hiện từ tháng 5/2021 tới tháng 8/2021 tại phòng mổ khoa phẩu thuật cột sống bệnh viên HN Việt Đức.

\subsection{Phương pháp nghiên cứu}

Thiết kế nghiên cứu: nghiên cứu tiến cứu mô tả cắt ngang

Cỡ mẫu: mẫu thuận tiện, trong nghiên cứu này chúng tôi tiến hành tiêm được cho 15 người bệnh

Nội dung nghiên cứu: Đối với tất cả NB, được thực hiện trên phòng mổ khoa phẫu thuật cột sống-bênhh viện HN Việt Đức. Đầu tiên tất cả NB được tiên mê nằm sấp trên bàn mổ thấu quang với gối độn mềm dưới bụng, sau đó phẫu thuật viên sẽ xác định tầng can thiệp phong bế dưới hướng dẫn của siêu âm. Bác sĩ sẽ dùng đâu dò cong với tần số 2-5 MHz, đầu tiên xác định tầng phâu thuật bằng lát cắt dọc đường giữa để xác định gai sau đốt sống $L 5$ và đường cạnh giữa để xác định mảnh sống $L 5$, qua đó đánh dấu mỏm ngang các đốt sống L3, L4 và L5 tương ứng trên da NB. Sau đó tiến hành sát trùng vùng can thiệp bằng betadin. Chải vải vô khuẩn che xung quanh vùng can thiệp, bọc đầu dò siêu âm bằng túi nilon vô trùng. Quay ngang đầu dò 90 độ xác định lỗ liên hợp dưới siêu âm lát cắt ngang là điểm dưới hình ảnh diên khớp $1 \mathrm{~cm}$. Chọc kim 25G dưới hướng dẫn của siêu âm qua lỗ liên hợp vào trong ống sống khoảng $1 \mathrm{~cm}$. Chụp Xquang đánh giá vị trí đầu kim bằng màn tăng sáng trong mổ, nếu vị trí sai thì đặt lại dưới hướng dẩn của màn tăng sáng, còn nếu đúng vị trí thì tiêm thuốc cản quang qua kim vào trong, nếu thuốc cản quang lan theo khoang ngoài màng cứng thì vị trí kim được ghi nhận là chính xác. Sau khi NB được ghi nhận kim đã ở vị trí chính xác như dự kiến, bác sĩ sẽ tiêm hỗn hợp thuốc gồm $1 \mathrm{ml}$ Lidocain $2 \%$ và $1 \mathrm{ml}$ Diprospan (7mg betamethasone) vào khoang NMC.

2.3 Chỉ số nghiên cứu và tiêu chuẩn đánh giá: Đánh giá vị trí đầu kim bằng máy tăng sáng trong mổ: đúng tầng, đúng vị trí

Độ chính xác của đâu kim: được xác định dựa vào chụp $X$ quang thấy sự tràn của thuốc cản quang qua đầu kim vào khoang ngoài màng cứng thìđược xác nhận là chính xác, thuốc lan ra ngoài lỗ liên hợp là chưa chính xác

2.4 Xử lý số liệu: số liệu nghiên cứu được xử lý theo thuật toán thống kê bằng phần mềm SPSS 18.0

\section{KẾT QUẢ NGHIÊN CỨU}

Nghiên cứu của chúng tôi thực hiện 15 mũi tiêm ở 15 NB: tiêm ngoài màng cứng qua lỗ liên hợp đốt sống 01 BN L34, 11 NB L45 và 03 NB L5S1; gồm 06 phải 09trái. Trong tổng số 15 kim thực hiện thì có 13 kim thành công như vậy tỷ lê chính xác của gây tê ngoài màng cứng qua lổ liên hợp có sự hướng dẫn của siêu âm là $86,7 \%$ được xác định bằng xquang có tiêm thuốc cản quang. Có 02 trường hợp không chính xác thì có 1 trường hợp sai tâng và 1 trường hợp đúng tầng và đúng vị trí lố liên hợp nhưng sau khi tiêm thuốc cản quang và kiểm tra dưới màn tăng sáng thì thuốc ở ngoài lỗ liên hợp; còn theo vị trí thì 1 trường hợp tầng L45 và 1 trường hợp L5S1, sau đó chúng tôi phải tiến hành thực hiện lại tiêm ngoài màng cứng dưới hướng dẫn của $X$ quang cho 02 trường hợp không chính xác này. Không có trường hợp nào xảy ra biến chứng, như đau đầu, tê, đau tăng lên, chóng mặt, dị ứng, tiêm thuốc vào mạch máu.

\section{BÀN LUÂN}

Nhìn chung, can thiệp giảm đau ngày càng đóng vai trò quan trọng trong điều trịđau do nhiều nguyên nhân gây nên và đặc biệt đối với nguyên nhân gây đau xuất phát từ cột sống. Đê̂ 
tăng độ chính xác và an toàn thì các phương pháp can thiệp giảm đau ngày nay thường được thực hiện dưới hướng dẫn của các phương tiện chẩn đoán hình ảnh [2]. Theo một số nghiển cứu, tiêm NMC không có hỗ trợ dẫn đường của chẩn đoán hình ảnh thì khả năng sai vị trí có thể lên tới $30-40 \%$ và phương pháp tiêm NMC qua lỗ liên hợp có hiệu quả giảm đau tốt hơn so với phương pháp tiêm NMC qua đường liên mỏm gai [3]. Tiêm NMC qua lỗ liên hợp đã được thực hiện dưới hướng dẫn của màn tăng sáng/cắt lớp vi tính cho kết quả tốt, chính xác, an toàn và được coi là phương pháp chuẩn trong tiêm NMC, nhưng nó có một số nhược điểm như tăng sự phơi nhiễm tia $X$ đối với NB và nhân viên y tế, chi phí cao, đầu tư máy móc đắt tiền, trang thiết bị bảo hộ nặng, nóng và không thoải mái ...,vì vậynhững nằm gần đây tiêm NMC qua lỗ liên hợp dưới hướng dẫn của siêu âmngày càng được chú ý hơn, đồng thờiphương pháp này cũng đã được chứng minh sự tin cậy và chính xác.

Trong nghiên cứu của chúng tôi, độ chính xác của tiêm NMC qua lỗ liên hợp thắt lưng dưới hướng dẫn của siêu âm sau đó được kiểm chứng bằng $x$ quang là $86,7 \%$. Hashemi đã báo cáo độ chính xác của tiêm NMC từ lỗ cựt dưới hướng dẫn của siêu âm là 95,8\%[4]. Yang báo cáo độ chính xác là $85 \%$ cho kỹ thuật tiêm NMC dưới hướng dẫn của siêu âm [5]. Còn theo Chumnanvej và $C s$ khi tiêm thắt lưng qua đường giữa, độ chính xác của đầu kim ở rễ thần kinh thắt lưng dưới hướng dẫn siêu âm là $62,8 \%$ và độ chính xác đầu kim của mỗi tâng là từ 7,14 tới 80,95\%[6].Do sự cản âm cao của xương và gián đoạn hình ảnh do hiện tượng cản âm phía sau xương nên những mốc giải phẫu của vùng cột sống lưng được nhận biết bằng siêu âm là khó khăn. Trong nghiên cứu này, chúng tôi sử dụng đường vào trong mặt phẳng cắt ngang của cột sống (axial approach) và được dẫn đường trong mặt phẳng chùm sóng siêu âm (in-plane), điều này làm cho kim được tăng sự kiểm soát chặt chẽ bởi chùm tia sóng siêu âm được phát dọc theo đầu dò của máy siêu âm. Phương pháp tiếp cận trong mặt phẳng đưa tới môt sự quan sát với thời gian thực toàn bộ kim. Trong thực tế, kim sẽ xuất hiện dưới dạng một đường thẳng tăng âm, điều này khác với kỹ thuật kim đi ngoài mặt phằng chùm sóng siêu âm (out of plane) khi đó kim chỉ dưới dạng một chấm. Các nghiên cứu cho thấy tiêm NMC qua lỗ liên hợp, kỹ thuật với kim được hướng dẫn trong mặt phẳng sóng siêu âm (in-plane) có độ chính xác cao hơn ngoài mặt phẳng sóng siêu âm (out of plane).
Gofeld[7] đã báo cáo sự chính xác của phương pháp tiêm NMC qua lỗ liên hợp dưới hướng dẩn của siêu âm, được kiểm chứng bằng chụp $x$ quang. Trong số 50 mũi tiêm được lên kế hoạch thực hiện thì có 46 mũi tiêm được thực hiện, còn 4 mũ̃i $(8 \%)$ vào L5S1 không thể thực hiển được. Trong số 46 mũi kim được thực hiện thì tất cả các kim (100\%) đều đúng tầng và nằm ở vị trí lỗ liên hợp sau khi được xác định dưới màn tăng sáng. Sau khi tiêm thuốc cản quang và kiểm tra có 42 trường hợp $(91,3 \%)$ trong lỗ liên hợp và có 4 trường hợp $(8,7 \%)$ ngoài lỗ liên hợp (rề thần kinh). Kim[8] đã cho biết trong nghiền cứu của mình số thủ thuật được tiến hành thành công là 86 trong tổng số 96 thủ thuật phong bễ rễ thần kinh đã được thực hiện, chiếm 89,6\%. Có 4 thủ thuật sai tầng cần can thiệp và 6 thủ thuật chưa chính xác vị trí lỗ liên hợp. Chúng tôi có 2 trường hợp thất bại, trong đó có 1 trường hợp sai tầng, đây là những ca đâu tiên chúng tôi thực hiện kỹ thuật, chưa có kinh nghiệm xác định tầng/vị trí đĩa đệm cần can thiệp, ngoài ra có 1 trường hợp tuy đúng tầng và vị trí lỗ liên hợp tuy nhiên khi chụp $x$ quang lên thì thuốc không vào bên trong lồ liênn hợp và ngoài màng cứng mà thuốc ở ngoài lỗ liên hợp.Theo chúng tôi, để đảm bảo chính xác đúng tầng cần can thiệp thì việc xác định chính xác mỏm ngang đốt sống $L 5$ là rất quan trọng. Để xác định đúng mỏm ngang đốt sống $L 5$ dưới siêu âm, chúng ta cần xác định chính xác gai sau và/hoặc mảnh sống L5 bằng cách đặt đầu dò siêu âm dọc theo đường giữa lưng và đường cạnh giữa, sau đó sẽ thấy được gai sau L5 to nhất, dưới cùng, hoặc sẽ thấy mảnh sống $L 5$ dưới cùng và khác biệt với cung sau S1. Chúng tôi chỉ có một trường hợp không tiêm được ngoài màng cứng mà thuốc lan ra ngoài lỗ liên hợp ở vị trí L5S1, đây là trường hợp vướng xương chậu làm kim không đủ hướng chếch vào trong lỗ liên hợp, để khắc phục trường hợp này theo các tác giả trên thế giới sử dụng đường vào chếch hoặc uốn cong đầu kim. Trong nghiên cứu của chúng tôi không có biến chứng nào được ghi nhận, NB sau thủ thuật được lưu lại trong bệnh viện ít nhất một giờ. Qua nghiên cứu này chúng tổi thây rằng để giảm tỷ lệ biến chứng như thủng màng cứng, tổn thươning rễ thần kinh, chúng tôi dùng kim chọc tủy sống với đường kính $25 \mathrm{G}$ nhỏ hơn so các nghiên cứu của các tác giả trên thế giới, về kỹ thuật chúng tôi dùng kỹ thuật của Galiano[9] để xác định lỗ liên hợp, cùng với sau khi kim bắt đầu qua dây chằng vàng thì sẽ tiếp tục đâm kim tiếp xuống khoảng $1 \mathrm{~cm}$, sau đó phải hút ra khi không có máu hoặc 
dịch trong ra thì mới tiến hành tiêm thuốc các bước tiếp theo.

\section{KẾT LUÂN}

Tiêm NMC dưới hướng dẫn của siêu âm là kỹ thuật an toàn và khả thi trong thực hành lâm sàng giúp nâng cao trong công tác điêu trị và chẩn đoán, nhưng không làm nhân viên y tế và người bênh phải phơi nhiễm với tia $X$.

Tuy nhiên, số lương NB của nghiên cứu còn ít, đòi hỏi phải làm tiếp để đánh giá độ an toàn, chính xác và hiệu quả của phương pháp.

\section{TÀI LIÊU THAM KHẢO}

1. S. Datta, "Systematic review of therapeutic lumbar transforaminal epidural steroid injections," Accessed: Aug. 12, 2021. [Online]. Available: www.painphysicianjournal.com.

2. T. Grau, R. W. Leipold, S. Fatehi, E. Martin, and J. Motsch, "Real-time ultrasonic observation of combined spinal-epidural anaesthesia," in European Journal of Anaesthesiology, Jan. 2004, vol. 21, no. 1, pp. 25-31, doi: 10.1017/S026502150400105X.

3. J. H. Levin, R. Wetzel, and M. W. Smuck, "The Importance of Image Guidance during Epidural Injections: Rates of Incorrect Needle Placement during Non-Image Guided Epidural Injections," ] Spine, vol. 1, no. 2, 2012, doi: 10.4172/21657939.1000113.

4. M. Hashemi, P. Dadkhah, M. Taheri, S. M.
Haji, S. Abootorabi, and B. Naderi-Nabi, "Ultrasound-Guided Lumbar Transforaminal Epidural Injections; A Single Center Fluoroscopic Validation Study," Bull Emerg Trauma, vol. 7, no. 3, pp. 251-255, 2019, doi: 10.29252/beat-070307.

5. Y. G et al. "Ultrasound-guided Versus Fluoroscopy-controlled Lumbar Transforaminal Epidural Injections: A Prospective Randomized Clinical Trial," Clin. J. Pain, vol. 32, no. 2, pp. 103108, 2016, doi: 10.1097/AJP.0000000000000237.

6. V. K. Chumnanvej, Sorayouth, Narongdet Wetchagama, "Accuracy of needle-tip localization by ultrasound guidance lumbar selective nerve root block: a prospective clinical study of 78 lumbar nerve roots block - PubMed." https://pubmed.ncbi.nlm.nih.gov/22295731/ (accessed Aug. 17, 2021)

7. M. Gofeld, S. J. Bristow, S. C. Chiu, C. K. McQueen, and L. Bollag, "Ultrasound-guided lumbar transforaminal injections: Feasibility and validation study," Spine (Phila. Pa. 1976)., vol. 37, no. 9, pp. 808-812, Apr. 2012, doi: 10.1097/BRS.0B013E3182340096.

8. D. Kim, D. Choi, C. Kim, J. Kim, and Y. Choi, "Transverse Process and Needles of Medial Branch Block to Facet Joint as Landmarks for UltrasoundGuided Selective Nerve Root Block," Clin. Orthop. Surg., vol. 5, no. 1, pp. 44-48, Feb. 2013, doi: 10.4055/CIOS.2013.5.1.44.

9. K. Galiano et al., "Real-time Sonographic Imaging for Periradicular Injections in the Lumbar Spine," J. Ultrasound Med., vol. 24, no. 1, pp. 3338, Jan. 2005, doi: 10.7863/JUM.2005.24.1.33.

\section{KHẢO SÁT KIẾN THỨC, THÁI ĐÔ VÀ THỰC HÀNH CỦA THAI PHU CÓ TUỔI THAI TỪ 36 TUẦ ĐẾN 37 TUẦN 6 NGÀY V̂̂ TÂM SOÁT NHIỄM STREPTOCOCCUS NHÓM B TẠI BÊ̂NH VIÊ̂N TỪ DŨ}

\section{TÓM TẮT}

Đăt vấn đề: Trong các tác nhân gây các bệnh nhiễm trùng ở trẻ sơ sinh, GBS là một trong các tác nhân phổ biến nhất, thường gây nhiếm trùng sơ sinh sớm và có thể dẫn tới tử vong. Việc thực hiện xét nghiệm tầm soát GBS sớm trong thai kì được chứng minh là làm giảm tỉ suất bệnh ở trẻ, tuy nhiên thực hành xét nghiệm này còn chưa thật phổ biến và trở thành vấn đề ngày càng được quan tâm [3]. Mục tiêu: Xác định tỉ lệ thai phụ ở tuổi thai từ 36 tuần đển 37 tuần 6 ngày có kiến thức đúng, thái độ đúng và

${ }^{1}$ Đại họ Y Dướ TPHCM

${ }^{2}$ Bềnh viền Tữ Dũ

Chịu trách nhiệm chính: Bùi Chí Thương

Email: buichithuong@ump.edu.vn

Ngày nhận bài: 10.8.2021

Ngày phản biên khoa hoc: 4.10 .2021

Ngày duyệt bài: 13.10.2021 Phạm Thị Bảo Châu1, Bùi Chí Thương1,
Phạm Phương Duy², Hồ Huỳnh Nhung

thực hành đúng về xét nghiệm tầm soát Streptococcus nhóm $B$ tai bênh viên Tữ Dũ. Phương pháp: Nghiên cứu cắt ngang trên 385 sản phụ tuổi thai từ 36 tuần đến 37 tuần 6 ngày khám thai tai Bênh viên Từ Dũ từ tháng 11/2020 đến tháng 3/2021. Kết quả: Có $27,5 \%$ sản phu có kiến thức đối với xét nghiêm tầm soát Streptococcus nhóm $B$, tỉ lệ này liên quan đến việc thai phu đã được thông tin về xét nghiêm này trước đó mà không liên quan đến các yếu tổ dịch tễ hay sản khoa khác. Măc dù vậy, gân phân nửa sản phụ khoảng $42,6 \%$ ủng hộ cho việc tầm soát thường qui đối với xét nghiệm tầm soát Streptococcus nhóm B. Nghiên cứu cũng ghi nhận có $6,8 \%$ sản phụ đã thực hiện xét nghiệm tai thời điểm phỏng vấn, đồng thời 6 tuần sau phỏng vẩn, chúng tôi ghi nhận số thai phụ thực hiện xét nghiệm này trong thai kì đến khi chưển da tại bênh viên Từ Dũ là 13\%. Kết luânn: Tỉ lệ sản phụ có kiến thức đối với xét nghiệm tầm soát Streptococcus nhóm $\mathrm{B}$ là 27,5\%. Phần lớn sản phụ chưa được thông tin, không có kiến thức đúng về xét nghiệm khi đến 
thời điểm thích hợp để tầm soát. Một nửa đối tượng nghiên cứu ủng hộ chiến lược tầm soát GBS thường qui. Tỉ lệ thực hiện xét nghiệm còn thấp.

Tư khóa: Tầm soát, Streptococcus nhóm B, chăm sóc trước sinh.

\section{SUMMARY}

KNOWLEDGE, ATTITUDE, AND PRACTICES OF GBS SCREENING IN WOMEN BETWEEN 36 WEEKS AND $376 / 7$ WEEKS AT TU DU HOSPITAL

Background: GBS is one of the common agents causing infection in newborns which may leads to deaths in certain cases. Screening strategy of GBS in pregnant women has been proved the ability to lower the prevalence of this disease; however, the practice of this test is still not well-known among women and do increase concerned as time goes by. Objective: To assess the knowledge, attitude, and current practices of pregnant women towards GBS screening at Tu Du Hospital. Methods: A cross-section study of 385 pregnant women from 36 to $376 / 7$ gestational weeks was conducted between November 2020 and March 2021 at Tu Du Hospital. Results: The rate of having certain knowledge about GBS screening was $27,5 \%$ [95\%CI: 0,23-0,32]. There were $42,6 \%$ women showed preference for universal culture-based GBS screening strategy over risk-based strategy. The practice rate when the interview started was $6,8 \%$ [95\%CI: 0,04-0,10]; however, after 6 weeks, there was totally $13 \%$ agreed to have the screening test in the end. Conclusions: The rate of having certain knowledge about GBS screening, the practice rate of the women quite low. However, almost half of pregnant women supported the universal screening strategy

Key words: Screening, Streptococcus group B, prenatal care.

\section{I. ĐẶT VẤN ĐỀ}

Tỉ lệ phát hiện chủng vi khuẩn này nói chung ở người phụ nữ khoảng $30 \%$, đa số trường hợp là mang trù̀ng, không gây bệnh, tuy nhiên số còn lại sẽ gây nhiều tác hại khó lường cho cả mẹ và thai nhi. Bằng chứng về việc tầm soát và can thiệp kháng sinh dự phòng trước khi sinh cho sản phụ để làm giảm tỉ lệ nhiễm trùng, cải thiện bệnh suất và tử suất cho trẻ đã được ghi nhận từ nhiều năm qua và trong nhiều hướng dẫn về chăm sóc tiền sản trên thế giới[3]. Tại một số nước đang phát triển, viêc thức hiên qui trình về xét nghiệm GBS còn chứa phổ biến, điển hình là ở Việt Nam. Việc thực hành thông qua các quá trình tư vấn của các nhân viên y tế nói chung cũng như chính bác sĩ lâm sàng nói riêng vẫn còn rất ít người biết đến và thực hiện, dẫn đến tỉ lệ thực hiện thực tế của xét nghiệm cũng rất ít. Nhận thấy được tâm quan trọng phải làm rõ các vấn đề liên quan nhằm đem lại sự chăm sóc tối ưu cho sản phụ và em bé sơ sinh, chúng tôi thực hiện nghiên cứu này để trả lời các ẩn số: "Bao nhiêu phần trăm sản phụ có kiến thức, thái độ và thực hành đúng về xét nghiệm tầm soát GBS trong thai kì?". Mục tiêu nghiên cứu

Xác định tỉ lệ thai phu ở tuối thai từ 36 tuần đến 37 tuần 6 ngày có kiến thức đúng, thái độ đúng và thực hành đúng về xét nghiệm tầm soát Streptococcus nhóm B tại bệnh viện Từ Dũ.

Xác định các yếu tố liên quan với kiến thức đúng, thái độ đúng và thực hành của sản phụ về xét nghiệm tầm soát Streptococcus nhóm $B$ tại bệnh viện Từ Dũ.

\section{II. ĐỐI TƯợNG VÀ PHƯƠNG PHÁP NGHIÊN CỨU Thiết kế nghiên cứu. Cắt ngang}

Dân số nghiên cứu. Sản phụ có tuổi thai từ 36 tuần đến 37 tuần 6 ngày có chỉ định thực hiện xét nghiệm tầm soát GBS trong 3 tháng cuối thai kì tại TPHCM.

Tiêu chuẩn nhận vào: Sản phụ có tuổi thai từ 36 tuần đến 37 tuần 6 ngày, đọc hiểu chữ viết tiếng Việt và đồng ý tham gia nghiên cứu.

Tiêu chuẩn loại trừ: Chống chỉ định thực hiện xét nghiệm tầm soát GBS: sản phụ có tiền căn sinh trẻ sớ sinh mắc bệnh nhiễm GBS, nước tiểu có GBS phát hiện trong thai kì, có chỉ định mổ lấy thai chủ động. Hoặc sản phụ mắc bệnh tâm thần, hoặc câm hoặc điếc.

Cỡ mấu. Cỡ mẫu: 385. Chọn mẫu thuận tiện

Biến số nghiên cứu. Biến số chính trong nghiên cứu là nhận thức, kiến thức về xét nghiệm tầm soát GBS, thái độ của sản phụ, và tỉ lệ thực hiện xét nghiệm này tại thời điểm phỏng vấn và sau phỏng vấn 6 tuần.

Phương pháp nhận bệnh và thu thập số liệu. Từ tháng $11 / 2020$ đến tháng 3/2021, chúng tôi tiến hành mời các sản phụ tuổi thai tữ 36 đến 37 tuần 6 ngày khám thai tại Bệnh viện Từ Dũ tham gia nghiên cứu:

Bước 1: Sàng lọc đối tượng và mời đối tượng tham gia nghiên cứu: Các thai phụ từ 36 đến 37 tuần 6 ngày có chỉ định xét nghiệm tầm soát GBS, sau khi đã trừ ra các trường hợp nằm trong chống chỉ định của xét nghiệm, chỉ những sản phụ đồng ý tham gia nghiên cứu mới bắt đầu tiến hành phỏng vấn.

Bước 2: Nghiên cứu dẫn đường: Theo dõi và ghi nhận kết quả 20 mẫu đầu tiên theo bộ câu hỏi nghiên cứu. Sau đó chỉnh sửa các lỗi diễn đạt của bộ câu hỏi, giúp bộ câu hỏi dễ hiểu và chính xác hơn.

Bước 3: Phỏng vấn và ghi nhận dữ liệu nghiên cứu: Việc trả lời câu hỏi của các đối tượng trong mẩu nghiên cứu được tiến hành theo phương pháp phỏng vấn và được thực hiện 
trong phòng riêng, chỉ có người phỏng vấn và sản phụ.

Bước 4: Ghi nhân kết quả: Sau khi hoàn thành cuộc phỏng vấn, nghiên cứu viên sẽ kiểm tra lại các thông tin và tổng hợp, nhập liệu các bộ trả lời câu hỏi hoàn chỉnh sau mỗi ngày.

Bước 5: Xử lý số liệu: Tiến hành nhập liệu bằng Excel, phân tích số liệu bằng STATA 14.0. Phân tích gồm 2 bước: bước 1 mô tả và phân tích đơn biến, bước 2 dùng mô hình hồi quy đa biến nhằm kiểm soát yếu tố gây nhiễu. Các phép kiểm được thực hiện với độ tin cậy 95\%.

Giấy phép $\mathbf{Y}$ đức. Nghiên cứu này được thông qua bởi Hội đồng Khoa học Bộ môn Sản Đại học Y Dược TPHCM [Số 2660/QĐ-ĐHYD, ngày 09/09/2020], Hội đồng đạo đức và Hội đồng nghiên cứu khoa học của bệnh viện Từ Dũ [Số 1928/BVTD-HĐĐĐ, ngày 02/11/2020].

\section{KẾT QUẢ NGHIÊN CỨU}

Nghiên cứu lây dữ liệu từ 385 sản phụ tuổi từ 36 đến 37 tuần 6 ngày khám thai tại Bệnh viện Từ Dũ từ tháng 11/2020 đến tháng $3 / 2021$ với tuổi trung bình của nghiên cứu là $30,76 \pm 0,53$ tuổi, lớn nhất là 44 và thấp nhất là 16 . Phần lớn sản phụ nằm trong nhóm tuổi 25-34 (61,8\%). Công chức/viên chức/nhân viên văn phòng là nghề chiếm tỉ lệ cao nhất $(37,4 \%)$. Số thai phụ có trình độ học vấn giáo dục nghề nghiệp và đại học/sau đại học ngang nhau (chiếm khoảng 25\% mỗi nhóm). Tỉ lệ sản phụ con so là $47 \%$, thấp hơn ở nhóm con rạ (53\%). Tuổi thai trung bình là $258,8 \pm 0,41$ ngày. Đa số sản phụ không ghi nhận bệnh lý phụ khoa nào trước đầy $(81,6 \%)$, tuy nhiển viêm âm đạo được ghi nhận chiếm tỉ lệ cao nhất trong các bệnh lý còn lại $(12,2 \%)$. Đa số sản phụ khám thai trước đó tại bệnh viện Từ Dũ $(95,6 \%)$.

Về biến số nhận thức của sản phụ, chúng tôi đánh giá thông qua câu hỏi được thông tin về
GBS trong quá trình mang thai trước đó hay không, thì thu được kết quả đa số sản phụ không được thông tin về xét nghiệm tầm soát GBS trong quá trình mang thai $(77,9 \%)$.

Bảng 1. Nhận thức về xét nghiệm tầm soát GBS

\begin{tabular}{|c|c|c|}
\hline Đặc điểm & $\begin{array}{c}\text { T'ân số } \\
(\mathrm{N}=385)\end{array}$ & $\begin{array}{l}\text { Tỉ lệ } \\
(\%)\end{array}$ \\
\hline \multicolumn{3}{|c|}{$\begin{array}{c}\text { Được thông tin về GBS trong quá trình } \\
\text { mang thai }\end{array}$} \\
\hline Có & 85 & 22,1 \\
\hline Không & 300 & 77,9 \\
\hline
\end{tabular}

Về mặt kiến thức của thai phụ về xét nghiệm, chúng tồi đánh giá qua 8 câu hỏi được tham khảo từ nghiên cứu ở Ả Rập trên 377 sản phụ hậu sản [1]. Trong đó, câu hỏi sản phụ trả lời có tỉ lệ đúng nhiều nhất là "GBS có thể lây truyền khi sinh em bé hay không?" (20,8\%). Rất ít sản phụ biết được thời gian phải sử dụng kháng sinh dự phòng khi có xét nghiệm tầm soát GBS dương tính (chỉ 6,8\% trả lời đúng). Nhìn chung, tỉ lệ trả lời sai của tất cả các câu hỏi đều trên 75\%.

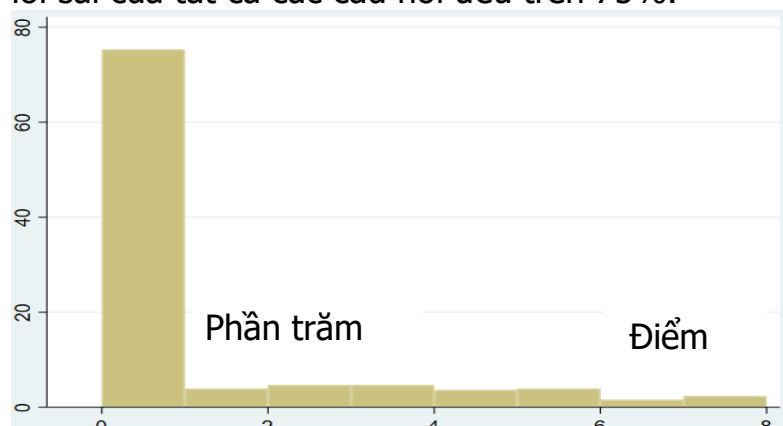

Biêư đồ 1. Phần bố điểm kiến thức về GBS, với mối câu trả lời đúng tính 1 điểm

Chúng tôi xác lập nếu sản phụ trả lời đúng ít nhất 1 câu được xem là có kiến thức, từ đó so sánh 2 nhóm có/không có kiến thức và tìm các yếu tố liên quan.

Bảng 2. So sánh đặc điểm giứa sản phụ có kiên thức và không có kiến thức về GBS

\begin{tabular}{|c|c|c|c|c|c|}
\hline Đặc điểm & $\begin{array}{c}\text { Có } \\
(\mathbf{N}=\mathbf{1 0 6})\end{array}$ & $\begin{array}{c}\text { Không } \\
(\mathbf{N}=\mathbf{2 7 9})\end{array}$ & $\mathbf{O R} *$ & $\mathbf{9 5 \%} \mathbf{~ C I}$ & p* \\
\hline Tuối mẹ & & & & & \\
\hline Từ 16-25 tuối & $11(10,4)$ & $35(12,5)$ & 0,77 & $0,37-1,60$ & 0,484 \\
\hline Từ 25-34 tuối & $69(65,1)$ & $169(60,6)$ & 1 & - & - \\
\hline Từ 35-44 tuối & $26(24,5)$ & $75(26,9)$ & 0,85 & $0,50-1,43$ & 0,543 \\
\hline Nghề nghiệp & & & & & \\
\hline Nội trợ & $20(18,8)$ & $82(29,4)$ & 1 & - & - \\
\hline Công nhân & $16(15,1)$ & $68(24,4)$ & 0,96 & $0,46-2,00$ & 0,923 \\
\hline $\begin{array}{c}\text { Công chức/Viên chức/Nhân viên } \\
\text { văn phòng* }\end{array}$ & $53(50,0)$ & $91(32,6)$ & 2,39 & $1,32-4,33$ & $\mathbf{0 , 0 0 4}$ \\
\hline Tự do & $17(16,0)$ & $38(13,6)$ & 1,83 & $0,86-3,89$ & 0,114 \\
\hline
\end{tabular}




\begin{tabular}{|c|c|c|c|c|c|}
\hline Học vấn & & & & & \\
\hline Biết đọc, biết viết & $0(0)$ & $3(1,1)$ & - & - & - \\
\hline Cấp 1 & $3(2,8)$ & $10(3,6)$ & 0,46 & $0,12-1,77$ & 0,258 \\
\hline Cấp 2* & $14(13,2)$ & $65(23,3)$ & 0,33 & $0,16-0,67$ & $\mathbf{0 , 0 0 2}$ \\
\hline Cấp 3 & $26(24,5)$ & $65(23,3)$ & 0,61 & $0,33-1,13$ & 0,114 \\
\hline Giáo dục nghề nghiệp* & $25(23,6)$ & $78(27,9)$ & 0,49 & $0,27-0,90$ & $\mathbf{0 , 0 2 1}$ \\
\hline Đại học/Sau đại học & $38(35,9)$ & $58(20,8)$ & 1 & - & - \\
\hline Biết đọc, biết viết & $0(0)$ & $3(1,1)$ & - & - & - \\
\hline Địa điếm khám thai & & & & & \\
\hline Bệnh viện Từ Dũ & $98(92,5)$ & $270(96,7)$ & 1 & - & - \\
\hline Bệnh viện tư & $1(0,9)$ & $1(0,4)$ & 2,76 & $0,17-44,47$ & 0,475 \\
\hline Phòng khám ngoài giờ* & $4(3,8)$ & $1(0,4)$ & 11,02 & $1,22-99,80$ & $\mathbf{0 , 0 3 3}$ \\
\hline Cơ sở y tế khác & $3(2,8)$ & $7(2,5)$ & 1,18 & $0,30-4,66$ & 0,812 \\
\hline Tuối thai & & & & & \\
\hline Từ 36 tuần đến 36 6/7 tuần & $46(43,4)$ & $129(46,2)$ & 1 & - & - \\
\hline Từ 37 tuâan đến 37 6/7 tuần & $60(56,6)$ & $150(53,8)$ & 1,21 & $0,71-1,76$ & 0,617 \\
\hline
\end{tabular}

$\left(^{*}\right)$ Hồi quy logistic đơn biến

Sau khi phân tích đơn biến, chúng tôi nhận thấy có 4 yếu tố liên quan đến kiến thức về xét nghiệm tầm soát GBS của thai phụ $(p<0,05)$ và đưa những yếu tố này vào phân tích đa biến thì còn lại 1 yếu tố đó là sản phụ có "nhận được thông tin về xét nghiệm GBS trước đó" hay không. Sản phụ có nhận thức sẽ có khả năng có kiến thức đúng về GBS cao gấp 196,78 lần.

Đối với thái độ của sản phụ về việc ủng hộ tầm soát thường qui, chúng tôi ghi nhận qua câu hỏi "Nên thực hiện xét nghiệm thường qui hay theo nguy cơ từng sản phụ ?" và ghi nhận kết quả theo 2 nhóm và so sánh 2 nhóm đó. Khi phân tích đơn biến, chúng tôi nhận thấy có 6 yếu tố liên quan đến thái độ về xét nghiệm tầm soát GBS của thai phụ. Sau khi đưa vào phân tích đa biến, chúng tôi thấy chỉ còn 1 yếu tố là liên quan tới thái độ của thai phụ, sản phụ có kiến thức liên quan tới GBS sẽ tăng khoảng 7,63 lần tỉ lệ có thái độ đúng đối với xét nghiệm tầm soát GBS.

\section{BÀN LUÂN}

Phần lớn sản phụ không có nhiêu kiến thức về xét nghiệm tầm soát GBS, chỉ có khoảng 27,5\% sản phụ có ít nhất một câu trả lời đúng về GBS. Tỉ lệ này ít hơn hẳn so với nghiên cứu mà chúng tổi tham khảo bộ câu hỏi với $100 \%$ các sản phụ đều trả lời đúng ít nhất 1 câu [1], xem bảng 4 . Sự khác biệt này có thể do chúng tôi ngoài 2 lựa chọn "Đúng/Sai" còn đưa ra lựa chọn thứ ba là "Không biết" nên sản phụ chưa nghe được về xét nghiệm sẽ có thể chọn lựa chọn này mà không chọn ngẫu nhiên vào hai lựa chọn "Đúng/Sai" gây sai lệch kết quả nghiển cứu, cũng vì thế tỉ lệ trả lời không đúng sẽ cao hơn, ngoài ra, thời gian thực hiện phỏng vấn là khác nhau, nghiên cứu của chúng tôi vào lúc tuổi thai 36-37 tuần, còn Alshengeti thực hiện khi sản phụ ở giai đoạn hậu sản. Kết quả này ít hơn so với nghiên cứu của Youden là $30 \%$ và của Ty Chow là 59\% [2], [4].

Bảng 4. So sánh các yếu tố liên quan với kiến thức về xét nghiệm tầm soát GBS của các nghiên cứu trước

\begin{tabular}{|c|c|c|c|}
\hline Nghiên cứu & $\begin{array}{l}\text { Nơi nghiên } \\
\text { cứu }\end{array}$ & Yếu tố liên quan & Tỉ lệ kiến thức đúng \\
\hline $\begin{array}{l}\text { Laura Youden } \\
\text { [4] (2005) }\end{array}$ & Canada & Nhóm tuổi và trình độ học vấn & $\begin{array}{l}\text { Đối tượng nghiên cứu } \\
\text { trung bình trả lời đúng } \\
50 \% \text { các câu hỏi }\end{array}$ \\
\hline $\begin{array}{l}\text { Ty Chow [2] } \\
\quad(2013)\end{array}$ & $\begin{array}{l}\text { Hồng Kông - } \\
\text { Trung Quốc }\end{array}$ & $\begin{array}{c}\text { Tam cá nguyệt } 3 \text { (so với tam cá } \\
\text { nguyệt } 1 \text { ), nhâân thức, thái độ, } \\
\text { thu nhập, nghề nghiệp, trình độ } \\
\text { học vấn, thời gian cư trú }\end{array}$ & $\begin{array}{l}\text { 59\% có ít nhất một câu } \\
\text { trả lời đúng }\end{array}$ \\
\hline $\begin{array}{l}\text { Amer Ashengeti } \\
\text { [1] (2020) }\end{array}$ & Ả Rập Saudi & $\begin{array}{l}\text { Nhóm tuối, trải nghiệm trước } \\
\text { đó, số lần mang thai trước đó }\end{array}$ & $\begin{array}{l}\text { 9,3\% đạt điếm trên bách } \\
\text { phẩn vị thứ } 75 .\end{array}$ \\
\hline Chúng tôi & TPHCM - VN & $\begin{array}{l}\text { Trình độ học vấn, địa điểm } \\
\text { khám thai, nhận thức }\end{array}$ & $\begin{array}{l}\text { 25,5\% đạt điểm trên } \\
\text { bách phân vị thứ } 75 \text { (có ít } \\
\text { nhất } 1 \text { câu trả lời đúng) }\end{array}$ \\
\hline
\end{tabular}


So với Youden, sự khác biệt cũng đến từ thời gian phỏng vấn khác nhau, còn nghiên cứu Ty Chow, sự khác biệt do bộ câu hỏi khác biệt tạo sự khác nhau đó[2]. Nhìn chung, sự thiếu sót về kiến thức phần lớn là do sự thiếu các hướng dẫn trong nước về tầm soát vi khuẩn GBS trước sinh, dẫn đến các thực hành cung cấp thông tin khác nhau giữa các bác sĩ, điều này cũng được đồng thuận trong các nghiên cứu trước[1].

Khoảng $42,6 \%$ sản phụ tin rằng thực hiện xét nghiệm tầm soát GBS thường quy cho tất cả sản phụ mang thai là biện pháp tốt để phòng ngừa các bệnh nhiễm trùng do GBS cho trẻ sau sinh. Tỉ lệ này thấp hơn một phần ba so với nghiên cứu ở Ả Râp Saudi (61,8\%)[1] và nghiên cứu ở Hồng Kông (66\%) [2]. Sự khác biệt này có thể là do cách suy nghĩ khác nhau ở các quốc gia khác nhau.

Hạn chế của đề tài: Vì là một nghiên cứu cắt ngang, nên chỉ mô tả hiện tượng của vấn đề nghiên cứu, xác định được các yếu tố liên quan tới kiến thức, thái độ, hành vi về xét nghiệm tầm soát GBS mà không hỗ trợ chúng tôi tìm được mối liên quan nhân quả. Phương pháp lấy mẩu thuận tiện chủ yếu dựa trên sự thuận lợi, dễ tiếp cận đối tượng, phù hợp với nguồn nhân lực và thời gian hạn chế nhưng thường mang tính chủ quan, không thể tính được sai số do chọn mẫu và không thể áp dụng phương pháp ước lượng thống kê để suy rông kết quả trên mẫu cho quần thể chung. Đồng thời, nghiên cứu cũng có thể có sai lệch trí nhớ về các trải nghiệm về xét nghiệm GBS, và sai lệch thông tin khi ghi nhận thông tin thực hiện xét nghiệm GBS của thai phụ trong thai kì dựa trên danh sách thực hiện xét nghiệm tầm soát GBS tại Bệnh viện Từ Dũ mà bỏ qua các cơ sở bên ngoài.

Chúng tôi cũng không tìm hiểu được các nguyên nhân dẫn đến việc đề nghị xét nghiệm tầm soát GBS vẫn còn khá thấp từ các bác sĩ. Mặt khác, nghiên cứu chỉ thực hiện trên các đối tượng chủ yếu khám thai tại bệnh viện Từ Dũ nên sẽ không thể đại diện tất cả sản phụ có tuổi thai từ 36 đến 37 tuần 6 ngày, mặc dù vậy bệnh viện Từ Dũ cũng là bệnh viện sản lớn nhất miền Nam, với hơn hàng nghìn lượt thăm khám mỗi ngày. Tóm lại, kết quả nghiên cứu chưa thể áp dụng cho cộng đồng dân số thành phố Hồ Chí Minh tuy vẫn đạt được một số kết quả dùng để tham khảo.

\section{KẾT LUÂN}

Với nghiên cứu có cõ̃ mẫu 385 chúng tôi thấy rằng tỉ lệ được thông tin về xét nghiệm tầm soát GBS ở thai phụ còn thấp. Từ đó tỉ lệ có được các kiến thức nên về vi khuẩn cũng như xét nghiệm GBS cũng không cao. Mặc dù vậy tỉ lệ thai phụ ủng hộ tầm soát thường qui đối với xét nghiệm này lên tới $42,6 \%$.

\section{TÀI LIÊU THAM KHẢO}

1. Alshengeti A., Alharbi A., Alraddadi S., et al. (2020), "Knowledge, attitude and current practices of pregnant women towards group B streptococcus screening: cross-sectional study, AlMadinah, Saudi Arabia", BMJ Open, 10(2), pp. e032487.

2. Chow Ty, William Wk. (2013), "Knowledge and Attitudes of Hong Kong Pregnant Women on Group B Streptococcus Screening", Hong Kong J Gynaecol Obstet Midwifery 2013, 13, pp. 45-51.

3. Workowski K. A., Berman S., Centers for Disease Control, et al. (2010), "Sexually transmitted diseases treatment guidelines, 2010", MMWR Recomm Rep, 59(RR-12), pp. 1-110.

4. Youden $L_{\text {., }}$ Downing M., Halperin B., et al. (2005), "Group B streptococcal testing during pregnancy: survey of postpartum women and audit of current prenatal screening practices", J Obstet Gynaecol Can, 27(11), pp. 1006-1012.

\section{THỰC TRANG ĐIỀU TRI THUỐC SINH HỌC Ở BÊNH NHÂN VIÊM KHỚP DẠNG THẤP TẠI KHOA CO' XƯO'NG KHỚP BỆNH VIỆN BẠCH MAI}

\section{TÓM TẮT}

\author{
${ }^{1}$ Bênh viên đa khoa tỉnh Hà Nam \\ ${ }^{2}$ Đại học Quốc Gia Hà Nội \\ ${ }^{3}$ Bềnh viền Bach Mai \\ Chịu trách nhiệm chính: Lại Hồng Thịnh \\ Email: laihongthinh@gmail.com \\ Ngày nhận bài: 6.8.2021 \\ Ngày phản biên khoa hoc: 6.10 .2021 \\ Ngày duyệt bài: 15.10.2021
}

Lại Hồng Thịnh ${ }^{1}$, Chu Đình Tới ${ }^{2}$, Bùi Hải Bình ${ }^{3}$

Muc tiêu: Mô tả thức trang sử dung thuốc sinh học (bDMARD) trong điều trị viêm khớp dạng thấp (VKDT) tại khoa Cơ Xương Khớp- Bệnh viện Bạch Mai (khoa CXK-BVBM) và xác định một số yếu tố ảnh hưởng. Đối tượng và phương pháp: Nghiên cứu mô tả cắt ngang tiến cứu kết hợp hồi cứu trên 71 bệnh nhân VKDT có dùng bDMARDs tại địa điểm nghiên cứu từ $01 / 2017$ đến 12/2020. Kết quả: bDMARD hay được chọn đâu tiên là thuốc ức chế IL-6 $(83,1 \%)$, có $29,1 \%$ bệnh nhân chuyển sang bDMARD thứ 2 (thường gặp nhất là chuyển sang nhóm ức chế 
TNF), thời gian duy trì thuốc của nhóm ức chế IL-6 là 131 tuần (CI95\%: 108,2-153,8); của nhóm ức chế TNF là 46 tuần (CI95\%: 10,4-81,6), $(p=0,007)$. Tỉ lệ tuân thủ điêuu trị thấp $(29,6 \%)$. Lý do hàng đâu của không tuân thủ điều trị là kinh tế $(35,6 \%)$ và đáp ứng tốt $(31,4 \%)$; của giãn liều là đáp ứng tốt $(62 \%)$ và kinh tế $(24,6 \%)$; của dừng thuốc là do ảnh hưởng của đại dịch Covid-19 $(40,6 \%)$, hết thuốc $(21,7 \%)$ và kinh tể $(20,3 \%)$; và của đổi thuốc là không đáp ứng $(30,3 \%)$, hết thuốc $(36,4 \%)$ vàkinh tế $(27,3 \%)$. Kêt luận: bDMARDs nhóm ức chế IL-6 được lựa chọn để khởi đâu điều trị nhiều nhất và có thời gian duy trì lâu hơn nhóm ức chế TNF. Tí lệ tuân thủ điêu trị thấp và lý do chính của không tuân thủ là không đủ khả năng tài chính. Các yếu tố như không đủ khả năng tài chính, ảnh hưởng của đại dịch Covid-19 và hết thuốc, hoặc không đáp ứng với bDMARDs điều trị là những lý do chính khiến cho bệnh nhân đổi hay dừng thuốc.

Tư khóa: viêm khớp dạng thấp, thuốc sinh học, thực trạng, Bệnh viện Bạch Mai.

\section{SUMMARY \\ CURRENT STATUS OF BIOLOGICAL TREATMENT IN RHEUMATOID ARTHRITIS PATIENT AT THE DEPARTMENT OF \\ RHEUMATOLOGY - BACH MAI HOSPITAL}

Objectives: Describe the current status of using biological drugs in the treatment of rheumatoid arthritis patients at the Department of Rheumatology Bach Mai Hospital and identify some influencing factors. Subjects and methods: A prospective cross-sectional descriptive study combined with a retrospective on 71 rheumatoid arthritis patients receiving biologic drugs at the study site from January 2017 to December 2020. Results: The first-line bDMARD of choice was IL-6 inhibitor (83.1\%), $29.1 \%$ of patients switching to the second biologic drug (the most common being TNF inhibitor), The maintenance time of the IL-6 inhibitor group was 131 weeks (CI95\%: 108,2-153,8), of the TNF inhibitor group was 46 weeks $(C I 95 \%: 10,4-81,6)(p=0.007)$. The rate of adherence was low $(29.6 \%)$. The leading reasons for non-adherence to treatment were economic (35.6\%) and good response $(31.4 \%)$; for dosage reduction were responsive (62\%) and economical (24.6\%); for bDMARD discontinuation were due to the effects of the Covid-19 pandemic $(40.6 \%)$, drug shortage $(21.7 \%)$ and economy $(20.3 \%)$; and for drug switching were non-response $(30.3 \%)$, drug shortage $(36.4 \%)$, and economical (27.3\%). Conclusion: Biologic drugs with IL-6 inhibitors were chosen for the most initiation of treatment and had a longer maintenance time than TNF inhibitors. Adherence rates were low and the main reason for nonadherence was financial incompetence. The main reasons for switching or discontinuing bDMARDs were factors such as financial incompetence, the impact of the Covid-19 pandemic and drug shortages, or nonresponse with bDMARD.

Keywords: Rheumatoid arthritis, biological drugs, reality, Bach Mai Hospital.

\section{I. ĐĂT VẤN ĐỀ}

VKDT là bệnh lý thấp khớp khá thường gặp tại Việt Nam cũng như trên thế giới. Thuốc chống thấp khớp làm thay đổi bệnh (DMARD) có vai trò rất lớn để ngăn ngừa diến tiến của bệnh. Các DMARD gồm hai nhóm là thuốc kinh điển (cSDMARDs) và bDMARDs. Đến nay có chín bDMARDs được chấp thuận trong điều trịVKDT ở châu Âu và ở Mỹ: năm thuốc ức chế TNF (Etanercept, Infliximab, Adalimumab, Certolizumab và Golimumab), một thuốc kháng IL-1 (Anakinra), một thuốc kháng tế bào T (Abatacept), một thuốc kháng tế bào $B$ (Rituximab) và một thuốc ức chế IL-6 (Tocilizumab) ${ }^{1}$.

Hiện nay, bệnh nhân VKDT sử dụng bDMARDs để điều trị ngày nhiều. Tuy nhiên, dùng thuốc càng lâu thì tỉ lệ bệnh nhân dừng thuốc, đổi thuốc cũng tăng dần và việc sử dụng nhóm thuốc này còn bị tác động của nhiều yếu tố như không hiệu quả, tác dụng phụ, kinh tế,....2,3. Muốn tăng cường hiệu quả điêu trị và hiệu quả sử dụngbDMARDs trong điều trị bệnh VKDT thì chúng ta cần phải có các nghiên cứu về tình trạng sử dụngbDMARDs, các nguyên nhân của tình trạng không tuân thủ điều trị, của việc đổi và ngừng bDMARDs.

Ở nước ta hiện nay đã và đang có các nghiên cứu đánh giá về hiệu quả, an toàn và các tác dụng phụ của một số bDMARD sở bệnh nhân VKDT. Tuy nhiên các nghiên cứu về tỉ lệ dùng thuốc, tình trạng điều trị bDMARDs còn ít. Vì vậy chúng tôi tiến hành đề tài này nhằm: mô tả thực trạng sử dụng thuốc sinh học trong điều trị viêm khớp dang thấp tai khoa Cớ Xương Khớp- Bênh viện Bạch Maivà xác định một số yếu tố ảnh hưởng.

\section{II. ĐỐI TƯỢNG VÀ PHƯƠNG PHÁP NGHIÊN CỨU}

1. Đối tượng. Đối tượng nghiên cứu là 71 bệnh nhân VKDT khởi đầuđiều trị bDMARDs tại khoa CXK-BVBM từ01/2017 đến 12/2020 và tiếp tục được theo dõi quá trình điều trị cho đến khi kết thúc nghiên cứu.

Tiêu chuẩn lựa chọn: Bênh nhân có đủ hồ sơ bệnh án từ lần điều trị bDMARD đầu tiên, đồng ý tham gia nghiên cứu và trả lời tất cả câu hỏi trong bệnh án nghiên cứu.

Tiêu chuẩn loai trừ: Bệnh nhân dưới 18 tuổi.

\section{Phương pháp}

Thiết kế nghiên cứu: Nghiên cứu mô tả cắt ngang, lấy số liệu hồi cứu và tiến cứu.

Phương thức chọn mẫu: Lấy mẫu thuận tiện.

Công cụ thu thập dữ liệu: Bệnh án nghiên cứu.

Thời gian thực hiện: Từ 08/2020 đến hết 07/2021.

Địa điểm nghiên cứu: Khoa Cơ xương khớp (với bệnh án tiến cứu) và phòng kế hoạch tổng 
hợp (với bệnh án hồi cứu)- bệnh viện Bạch Mai.

\section{Một số định nghĩa:}

-Đáp ứng tốt/không đáp ứng: Bệnh nhân trả lời là đỡ/khồng đõ khi được hỏi về nguyên nhân không tuân thủ điều trị, nguyên nhân giãn liều, giảm liều, dừng thuốc, đổi thuốc.

-Kinh tế: Bệnh không đủ khả năng kinh tế để tiếp tục dùng bDMARD đúng theo y lệnh

-Tuân thủ điều trị: Lượt tuân thủ điều trị là lượt mà bệnh nhân dùng thuốc theo chỉ định của bác sỹ, bệnh nhân tuân thủ điều trị khi có $\geq 80 \%$ lượt là lượt tuân thủ.

-Lượt giãn liều: Khoảng cách với lượt điều trị trước đó dài hơn khuyến cáo.

-Lượt dừng thuốc: Khoảng cách với lượt điều trị trước đó dài hơn 3 lần khuyến cáo.

-Lượt đổi thuốc: Dùng thuốc khác lượt trước đó và không phải là dừng thuốc.

3. Xử lý số liệu: Chúng tôi sử dụng phần mềm IBM SPSS Statistics 20.0.

\section{KẾT QUẢ NGHIÊN CỨU}

1. Đặc điểm chung của đối tượng nghiên cứu

Bảng 1: Đặc điểm chung của bệnh nhân nghiên cứu

\begin{tabular}{|c|c|c|c|}
\hline \multicolumn{2}{|c|}{ Mức độ hoạt động bệnh (n=71) } & \multicolumn{2}{c|}{ csDMARD(n=71) } \\
\hline Nhè-n (\%) & $4(5,6)$ & Có dùng-n (\%) & $64(91,9)$ \\
\hline Vưa-n (\%) & $39(54,9)$ & Không dùng-n (\%) & $7(9,9)$ \\
\hline Mạnh-n (\%) & $28(39,4)$ & Số thuốc trung bình & $1,44 \pm 0,75$ \\
\hline Corticoid (mg) & $\mathbf{7 , 9 7 \pm 5 , 2}$ & MTX-n/\%/liều (mg/tuần) & $60 / 84,5 / 15,27 \pm 3,54$ \\
\hline Có dùng-n (\%) & $58(81,7)$ & HCQ-n/\%/liều (mg/ngày) & $31 / 43,7 / 200$ \\
\hline \multirow{2}{*}{ Không dùng-n (\%) } & \multirow{2}{*}{$13(18,3)$} & SSA-n/\%/liều (g/ngày) & $7 / 9,9 / 1,29 \pm 0,49$ \\
\cline { 3 - 4 } & & LEF- n/\%/ liêuu (mg/ngày) & $3 / 4,2 / 20$ \\
\hline
\end{tabular}

Bệnh nhân có mức độ hoat động bệnh nhẹ, trung bình và nặng lần lượt là $5,6 \%, 54,9 \%$ và 39,4\%. Trước khi điều trị bDMARD, 91,9\% bệnh nhân có sử dụng CSDMARD và trung bình mỗi bệnh nhân dùng $1,44 \pm 0,75$ thuốc. Tỉ lệ bệnh nhân có dùng methotrexat, thuốc kháng sốt rét tổng hợp, sulfasalazin và leflunomid lần lượt là $84,5 \%), 43,7 \%, \quad 9,9 \%$ và $4,2 \%$. Liều methotrexat trung bình là $15,27 \pm 3,54 \mathrm{mg} /$ tuần và liều thuốc chống sốt rét tổng hợp là $200 \mathrm{mg} / \mathrm{ngày}$ (tính theo HCQ). Có $81,7 \%$ bệnh nhân có sử dụng corticoid trước khi dùng bDMARD với liều trung bình là $7,97 \pm 5,2$ $\mathrm{mg} / \mathrm{ngày}$ tính theo Methylprednisolon (Bảng 1).

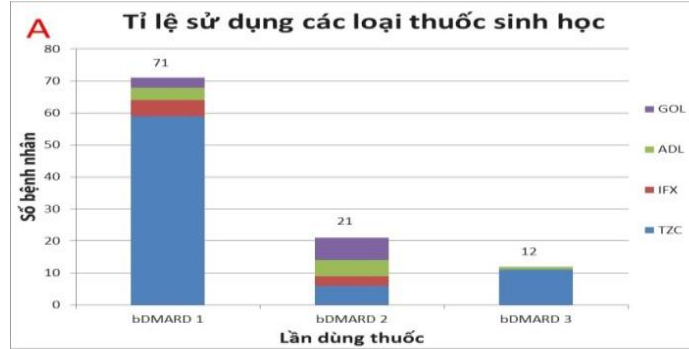

2. Thực trang sử dung bDMARD. Có $83,1 \%$ bểnh nhẩn lựa chon thuốc ức chế IL-6 là thuốc khởi đầu, 16,9\% lựa chọn thuốc ức chế TNF. Có $21(29,6 \%)$ bệnh nhân chuyển sang bDMARDs thứ 2 và 12 bênh nhân chuyển sang thuốc thứ $3(16,6 \%)$. Khi chuyển sang thuốc thứ 2 , nhóm ức chế TNF chiếm 71,4\%, nhóm ức chế IL-6 chiếm $28,6 \%$. Ở bDMARD thứ 3 thuốc ức chế IL-6 chiếm 91,7\% và thuốc ức chế TNF chiếm 8,3\% (Hình $1 A$ ). Thời gian duy trì bDMARD thứ nhất của nhóm ức chế IL-6 là 131 tuần (CI95\%: 108,2-153,8), của nhóm ức chế TNF là 46 tuần (CI95\%: 10,4-81,6), sự khác biệt có ý nghĩa thống kê với $p<0.05$ (Hình 1B).

B

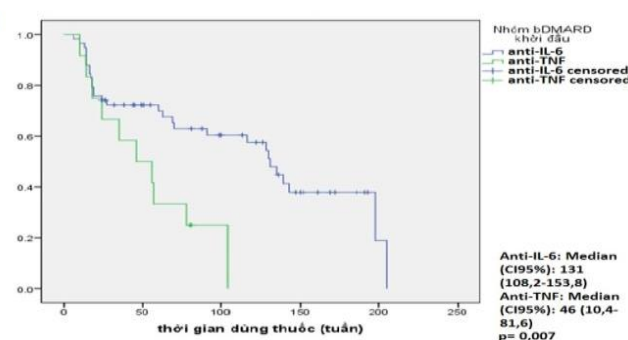

Hình 1: Tỉ lệ và thời gian sử dụng bDMARD

(A): Tỉ lệ sử dụng các thuốc sinh học, $(B):$ Thời gian duy trì thuốc sinh học đâu tiên

Có $83,1 \%$ bệnh nhân lựa chọn thuốc ức chế IL-6 là thuốc khởi đầu, 16,9\% lựa chọn thuốc ức chế TNF. Có $21(29,6 \%)$ bệnh nhân chuyển sangbDMARDs thứ 2 và 12 bệnh nhân chuyển sang thuốc thứ $3(16,6 \%)$. Khi chuyển sang thuốc thứ 2, nhóm ức chế TNF chiếm 71,4\%, nhóm ức chế IL-6 chiếm 28,6\%. Ở bDMARD thứ 3 thuốc ức chế IL-6 chiếm $91,7 \%$ và thuốc ức chế TNF chiếm 8,3\% (Hình 1A). Thời gian duy trì bDMARD thứ nhất của nhóm ức chế IL-6 là 131 tuần (CI95\%:108,2-153,8), của nhóm ức chế TNF là 46 tuần (CI95\%: 10,4-81,6), sự khác biệt 
có ý nghĩa thống kê với $\mathrm{p}<0.05$ (Hình 1B).

Có $21(29,6 \%)$ bệnh nhân tuân thủ điều trị và 50 (70,4\%) bệnh nhân không tuân thủ. Trong tổng số 918 lượt điều trị có $309(33,7 \%)$ lượt không tuân thủ điều trị, $374(40,7 \%)$ lượt giãn liều, $69(7,5 \%)$ lượt dừng thuốc, $33(3,6 \%)$ lượt đổi thuốc (Hình 2A, 2B).

Kinh tế $(35,6 \%)$, đáp ứng tốt $(31,4 \%)$, ảnh hưởng của đại dịch Covid-19 (19,4\%) và hết thuốc $(11 \%)$ là các nguyên nhân chính của việc không tuân thủ điều trị. Các lý do còn lại chiếm 2.6\% (không đáp ứng, tác dụng phụ và các lý do
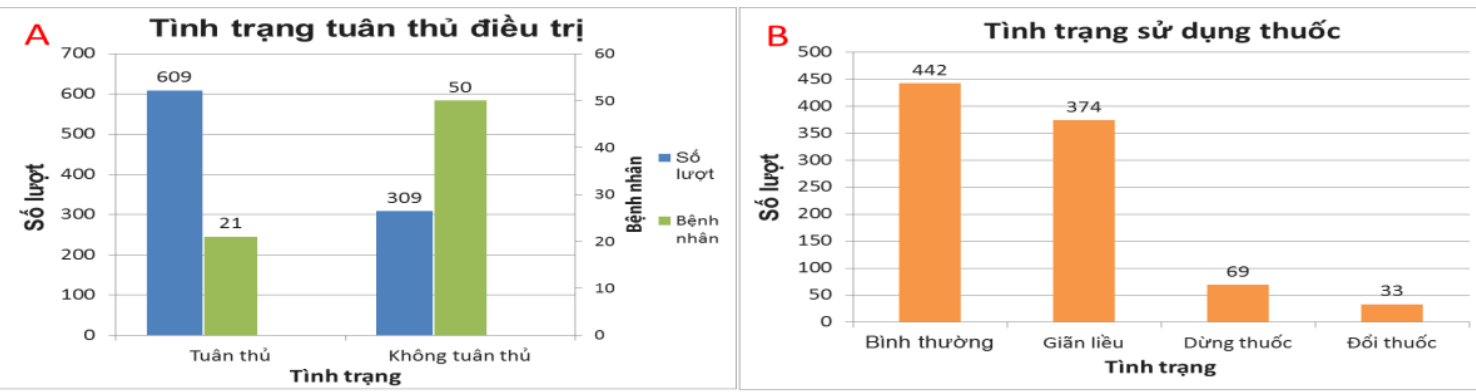

Hình 2: Tình trạng tuân thủ và sử dụng bDMARD

(A): Tỉ lệ tuân thủ điều trị; (B): Tình trạng sử dụng thuốc
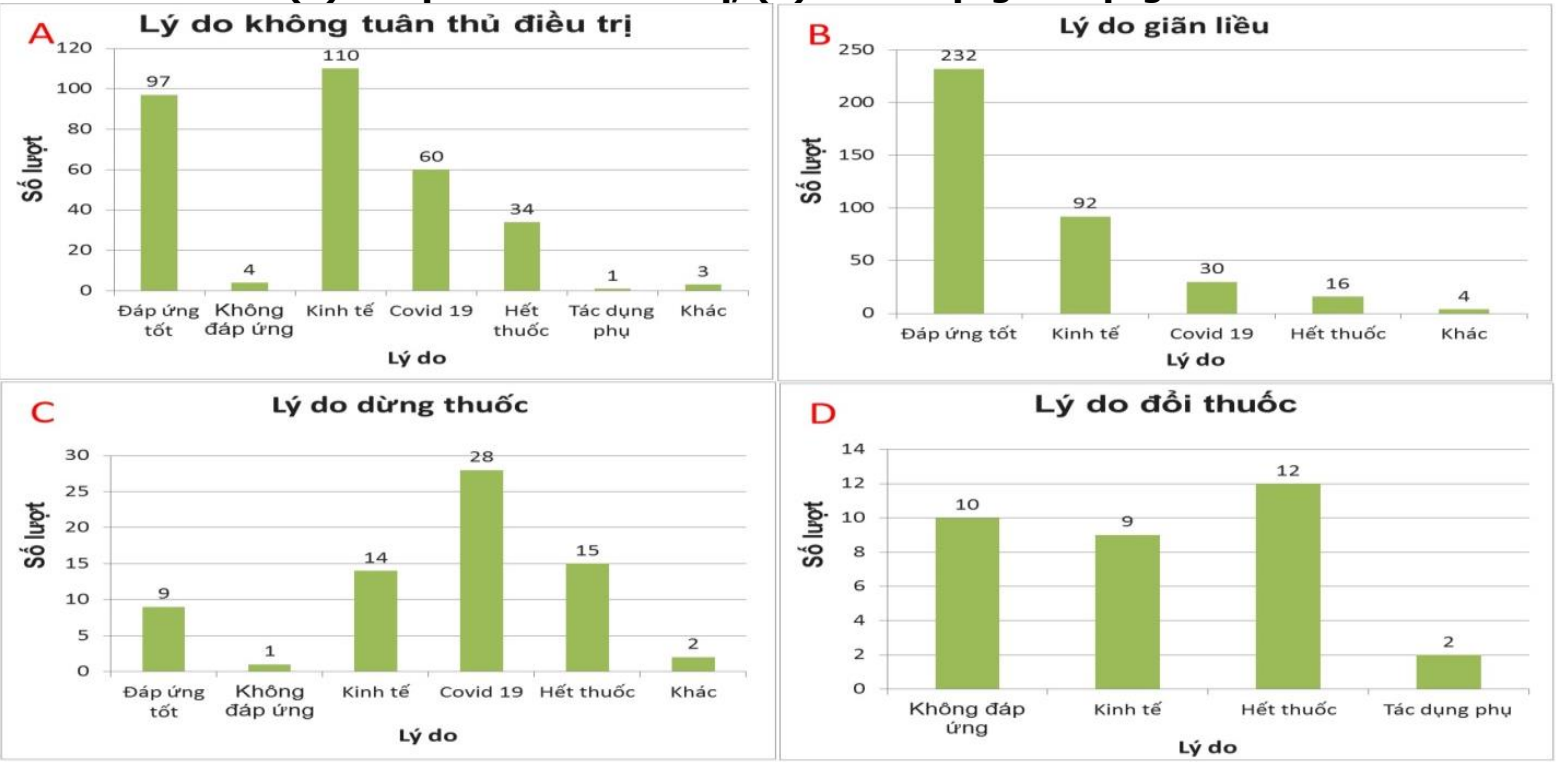

Hình 3: Lý do không tuân thủ điều trị, giãn liều, dừng thuốc và đổi thuốc

(A): Lý do không tuân thủ điều trị; (B): Lý do giãn liêu

(C): Lý do dừng thuốc; (D): Lý do đổi thuốc.

\section{BÀN LUÂN}

Khi bắt đầu được chỉ định dùng bDMARDs để điều trị, phần lớn bệnh nhân có mức độ hoạt động bệnh trung bình và mạnh $(94,4 \%)$, tương tự với nghiên cứu của Emma Sullivan ở cả nhóm bệnh nhân Châu Âu $(94 \%)$ và nhóm bệnh nhân Nhật Bản $(80,8 \%)^{3}$. Phần lớn bệnh nhân có điều trị cSDMARD (91,9\%) và thuốc CSDMARD được lựa chọn nhiều nhất là methotrexat $(84,5 \%)$, tương đồng với các kết quả nghiên cứu của Aaltonen (lần lượt là $86 \%$ và $57 \%)^{4}$ và của Emma Sullivan (nhóm bệnh nhân Châu Âu/Nhật Bản lần lượt là $84,7 \% / 78,6 \%$ và $91,5 \% / 87,3 \%)^{3}$. Điều này chứng tỏ phần lớn các bác sỹ đều tuân 
thủ theo các khuyến cáo điều trị của $A C R$ và EULAR hiện nay, 5 .

Trung bình mỗi bệnh nhân sử dụng 1,44 $\pm 0,75$ thuốc csDMARD, tương tự nghiên cứu của Emma Sullivan ${ }^{3}$ cả cả nhóm bệnh nhân Châu Âu $(1,8 \pm 0,9)$ và Nhật Bản $(1,3 \pm 0,8)$. Điều này thể hiện đa số các bểnh nhân được điều tritưư hai thuốc trở xuốngchứ ít khi kết hợp 3 thuốc CSDMARD, phù hợp với các khuyến cáo điều trị hiện taị ${ }^{5,6}$.

Có $81,7 \%$ bênh nhân có điều tri corticoid với liêu trung bình là $7,97 \pm 5,2 \mathrm{mg} / \mathrm{ngày}$ (tính theo Methylprednisolon) cao hơn so với nghiên cứu của Aaltonen $(69 \% \text { và } 4 \mathrm{mg})^{4}$. Lý do của sự khác biệt này có thểà do corticoid là một thuốc kê đớn nhưng ở nước ta lại có thể mua được khá dễ dàng ở các quây thuốc mà không cần đơn thuốc hợp lệ.

Trong kết quả của chúng tôi,bDMARD hay được lựa chon đầu tiên thuốc ức chế IL-6 $(83,1 \%)$, trong khi theo các kết quả khác thìnhóm ức chế TNF hay được lựa chọn trước như Brodszky $(95,4 \%)^{2}$ và Emma Sullivan $(80,8 \%$ ở nhóm Châu Âu và $64,6 \%$ ở nhóm Nhât Bản) 3 . Điều này có thể do ở nước ta thuốc ức chế IL-6 mà cụ thể là tocilizumab có chi phí sau bảo hiểm y tế cho mỗi tháng thấp hơn nên được ưu tiên lựa chọn trước mặc dù khuyến cáo của EULAR 2019 và $A C R 2021$ không ưu tiên nhóm nào hơn ${ }^{5,6}$.

Có 29,6\% bệnh nhân chuyển sang loai bDMARD thứ 2 và $16,6 \%$ bệnh nhân chuyển sang thuốc thứ 3trong khikết quả của Brodszky hai tỉ lệ này theo thứ tự là $59,6 \%$ và $29,1 \%{ }^{2}$, sự khác biệt này có thể vì nghiên cứu của chúng tôi có thời gian theo dõi ngắn hơn nên tỉ lệ đáp ứng với bMARDs còn cao và bệnh nhân chưa cần đổi thuốc. Khi chuyển sang thuốc thứ 2 thuốc nhóm ức chế TNF chiếm phần lớn $(71,4 \%)$ khác với kết quả của Emma Sullivan (bênh nhân Châu Âu, thuốc ức chế TNF chiếm ít hơn với 47,9\%) thuốc được lưa chon khởi đầu nhiều hơn ở nghiên cứu của chúng tôi và các nghiên cứu khác khác nhau nên khi chuyển sang thuốc thứ hai cũng sẽ có xu hướng ngược nhau, điều này tuân theo các hướng dẩn điều trị hiện có (ưu tiên đổi sang nhóm thuốc khác hơn là đổi thuốc trong cùng một nhóm $)^{5,6}$.

Thời gian duy trì bDMARDs đầu tiên của nhóm ức chế IL-6 dài hơn nhóm ức chế TNF (131 tuần (CI95\%:108,2-153,8) và 46 tuần (CI95\%: 10,4-81,6)), ( $p=0.007)$, tương đương vớikết quả của Brodszky và của Emma Sullivan ${ }^{3}$.

Theo kết quả của chúng tôi thu được, chỉ có 29,6\% (21/71) bệnh nhân tuân thủ điều trị, khác với nghiên cứu của Berger $(80 \%)^{7}$. Điều này có thể vì chúng tôi tiến hành nghiên cứu trong thời gian xảy ra đại dịch Covid-19 và việc bệnh nhân không đủ khả năng tài chính để chi trả cho việc điều trị bDMARDs.

Các lý do gây dừng thuốc gồm ảnh hưởng của đại dịch Covid-19 (40,6\%), hết thuốc $(21,7 \%)$, kinh tế $(20,3 \%)$, đáp ứng tốt $(13 \%)$, không đáp ứng $(1,4 \%)$ và các lý do khác $(2,9 \%)$, trong nghiên cứu của Brodszky, các lý do gây dừng thuốc là không hiệu quả (60\%), tác dụng phụ $(30 \%)$, các lý do khác $(10 \%)^{2}$.Lý do dẫn đến sự khác nhau này có thể là trong thời gian nghiên cứu nước ta có một số thời gian thực hiện giãn cách xã hội, sự khổng sẵn cóbDMARDs ở nước ta cũng như khả năng kinh tế của bệnh nhân.

Các lý do gây đổi thuốc hàng đầu là hết thuốc $(36,4 \%)$, không đáp ứng $(30,3 \%)$,và kinh tế $(27,3 \%)$, có sự khác biệt với các kêt quả của các tác giả khác như Rashid ${ }^{8}$ (không đáp ứng $50,5 \%$, không rõ lý do $25,1 \%$ và tác dụng phụ $22,3 \%$ ), Brodszky ${ }^{2}$ (tác dụng phụ $41 \%$ và không đáp ứng39,6\%). Điều này có thể do sự không sẵn có của bDMARD ởnước ta và khả nắng kinh tế bệnh nhân.

\section{KẾT LUẬN}

Nhóm bDMARD hay được lựa chọn đầu tiên trong điều trị VKDT ở khoa CXK-BVBM là thuốc ức chế IL-6, thời gian duy trì bDMARD đầu tiên của nhóm ức chế IL-6 dài hơn nhóm ức chế TNF. Tỉ lệ tuân thủ điều trị khá thấp so với các nước khác trên thế giới. Lý do hàng đầu của việc không tuân thủ là không đủ khả năng tài chính. Đại dịch Covid-19,hết thuốcvà không đủ khả năng tài chínhlà các lý do chính của việc dừng thuốc. Trong khi các yếu tố chính gây đổi thuốc là không đáp ứng, hết thuốc vàkhông đủ khả năng tài chính. Nghiên cứu của chúng tôi chỉ thực hiện tai khoa CXK-BVBM và trong thời gian ngắn, vì thể cần thực hiện thêm các nghiên cứu tại các cơ sở y tế khác và trong thời gian dài hơn để có được thông tin bao quát hơn về thực trạng sử dụng bDMARD trong điều trị VKDT ở nước ta.

\section{TÀI LIÊU THAM KHẢO}

1. Van Vollenhoven RF. Biologics for the Treatment of Rheumatoid Arthritis. Cham: Springer; 2016.

2. Brodszky V, Biro A, Szekanecz $Z$, et al. Determinants of biological drug survival in rheumatoid arthritis: evidence from a Hungarian rheumatology center over 8 years of retrospective data. Clinicoecon Outcomes Res. 2017;9:139-147.

3. Sullivan E, Kershaw J, Blackburn S, Mahajan P, Boklage SH. Biologic Disease-Modifying Antirheumatic Drug Prescription Patterns Among Rheumatologists in Europe and Japan. Rheumatol Ther. 2020. 
4. Aaltonen KJ, Joensuu JT, Pirila $L$, et al. Drug survival on tumour necrosis factor inhibitors in patients with rheumatoid arthritis in Finland. Scand J Rheumatol. 2016;46(5):359-363.

5. Smolen JS, Landewe RBM, Bijlsma JWJ, et al. EULAR recommendations for the management of rheumatoid arthritis with synthetic and biological disease-modifying antirheumatic drugs: 2019 update. Ann Rheum Dis. 2020;79(6):685-699.

6. Fraenkel L, Bathon JM, England $B R$, et al. 2021 American College of Rheumatology Guideline for the Treatment of Rheumatoid Arthritis. Arthritis Care Res (Hoboken). 2021;73(7):924-939.
7. Berger N, Peter M, DeClercq J, Choi L, Zuckerman AD. Rheumatoid arthritis medication adherence in a health system specialty pharmacy. The American journal of managed care. 2020;26(12):e380-e387.

8. Rashid N, Lin AT, Aranda G, Jr., et al. Rates, factors, reasons, and economic impact associated with switching in rheumatoid arthritis patients newly initiated on biologic disease modifying antirheumatic drugs in an integrated healthcare system. Journal of medical economics. 2016;19(6):568-575.

\section{KẾT QUẢ HÓA TRI PHÁC Đồ CHỨA PLATIN TRONG ĐIỀU TRI UNG THƯ BIỂU MÔ TUYẾN VÚ Có Bộ BA ÂM TÍNH TÁI PHÁT DI CĂN}

\section{TÓM TẮT.}

Mục tiêu: Đánh giá kết quả điều trị bằng phác đồ hóa chất chứa platin trên bệnh nhân ung thư biểu mô tuyến vú có bộ ba âm tính (BBAT) tái phát di căn. Đối tượng và phương pháp nghiên cứu: Nghiên cứu mồ tả hồi cứu trên 56 bệnh nhân được chẩn đoán ung thư biểu mô tuyến vú có BBAT tái phát hoăc di căn. Kết quả: Đặc điểm nhóm nghiên cứu: Tuổi trung bình ở thời điểm tái phát, di căn là $49,2 \pm 12,2$. Thời gian sống thêm không bệnh (DFS) là 16,3 tháng. Trong 56 bệnh nhân điều trị bằng phác đồ chứa platin, có 20 bệnh nhân được điêuu trị bằng phác đồ paclitaxel carboplatin chiểm 35,7\%, 36 bệnh nhân được điều trị bằng phác đồ gemcitabine - carboplatin chiểm 64,3\%. Tỷ lệ đáp ứng chung của phác đồ là $58,9 \%$; trong đó $10,7 \%$ đáp ứng hoàn toàn, đáp ứng 1 phân là 48,2\%, bệnh giữ nguyên là $12,5 \%$, bệnh tiến triển là $28,6 \%$. Tỷ lệ đáp ứng ở nhóm bệnh nhân điều trị phác đồ bước 1 là 67,5\%, cao hơn so với nhóm bệnh nhân điều ở bước 2 là $37,5 \%$, sự khác biệt có ý nghĩa thống kê với $p=0,039$. Trung vị thởi gian sống thêm bệnh không tiến triển là 7 tháng. Độc tính của phác đồ thường gặp chủ yếu là độ 1,2 . Các độc tính thường gặp là hạ bạch câu hạt $(63,5 \%)$, hạ huyết sắc tố $(50 \%)$, hạ tiểu cầu $(26,8 \%)$, rụng tóc $(46,4 \%)$, nôn và buồn nôn $(51,7 \%)$. Kết luấn: Hóa trị phác đồ chứa platin được chứng minh có hiệu quả, độc tính của phác đồ chấp nhận được trên nhóm bệnh nhân UTV BBAT tái phát di căn, do vậy có thể áp dung trong điều trị trong điều kiện hiện nay ở nước ta hiền nay.

Tư khóa: Ung thư vú bộ ba âm tính, platin, thời gian sống thêm bệnh không tiến triển.

\footnotetext{
${ }^{1}$ Trường Đại học Y Hà Nội

²Bênh viên $K$

Chịu trách nhiệm chính: Bùi Thành Lập

Email: lapxuanthu.bhn@gmail.com

Ngày nhận bài: 11.8.2021

Ngày phản biện khoa học: 7.10.2021

Ngày duyệt bài: 15.10.2021
}

\section{SUMMARY \\ THE EFFICACY OF PLATIN-BASE CHEMOTHERAPY OF RECURRENT OR METASTATIC IN THE \\ TRIPLE NEGATIVE BREAST CANCER}

Objectives: To evaluate the efficacy of platinbase chemotherapy of metastatic of triple negative breast cancer. Patients and methods: Retrospective, descriptive study on 56 patients with recurrent or metastatic of triple negative breast cancer, were treated with platin-base chemotherapy regiment at National Cancer Hospital. Results: The mean age was 49,2 $\pm 12,2$. Mean disease-free survival time (DFS) was 16,3 months. The overall response rate (ORR) of the regimen was $58,9 \%$. The complete response rate was $10,7 \%$, the partial response rate was $48,2 \%, 12,5 \%$ of the patients were stable and $28,6 \%$ of the patients had progressive disease. ORR in first-line therapy was better than that in the secondline of treatment (ORR: $67,5 \%$ vs $37,5 \% ; p=0,039$ ). The median progression-free survival was 7,0 months. The common toxicity was neutropenia $(63,5 \%)$, anemia (50\%), 26,8\% for thrombocytopenia, hair loss $(46,4 \%)$, and $51,7 \%$ for vomiting and nausea. Conclusions: Platinum-based chemotherapy is effective in high response rates and progression-free survival for patients with recurrent or metastatic of triple negative breast cancer. However, it is necessary to evaluate and closely monitor the toxicity of the regimen during treatment

Keyword: Triple negative breast cancer, platin, progression-free survival.

\section{I. ĐĂT VẤN ĐỀ}

Theo GLOBOCAN 2020, ung thư vú (UTV) là loại ung thư có tỷ lệ mắc nhiếu nhất trên toàn thế giới và là nguyên nhân gây tử vong thứ 5 sau ung thư phổi, đại trực tràng, gan và dạ dày ở cả 2 giới. Riêng ở nữ giới, UTV chiếm $1 / 4$ số trường hợp ung thư mới mắc và chiếm $1 / 6$ tổng số các ca tử vong do ung thư. Tại Việt Nam, tỷ lệ 
mắc mới UTV chuẩn theo tuổi là $34,2 / 100.000$ dân, đứng đầu trong các loại ung thư phổ biến ở nữ với 21.555 trường hợp và đứng thứ 4 trong số các nguyên nhân tử vong do ung thư nữ giới với 9.345 trường hợp, đứng sau ung thư gan, phổi và dạ dày [1].

UTV bộ ba âm tính được xác định bởi thu thể nội tiết estrogen $(E R) /$ progesterone $(P R)$ và yếu tố phát triển biểu bì Her-2 âm tính, chiếm khoảng 12-20\% trên tổng số các loại UTV. Kiểu hình này có tiên lượng xấu với đặc điểm riêng biệt về yếu tố nguy cớ, đặc điểm phân tử, biểu hiện lâm sàng, mô bệnh học, đáp ứng điều trị, di căn và tái phát [2], [3]. UTV có bộ ba âm tính có tỷ lê tái phát di căn rất cao trong những năm đâu tiên sau điều trị đặc biệt cao điểm trong 3 năm đầu [4].

Trên thế giới, nhiều nghiên cứu điêu trị UTV BBAT tái phát di căn bằng phác đồ hóa chất có chứa platin cho thấy hiệu quả điều trị cao hơn so với phác đồ không chứa platin [2], [5]. Zhang và CS (2015) đã nghiên cứu trên 364 BN UTV BBAT di căn điêu trị hóa chất bước 1 trong đó có 218 $\mathrm{BN}$ được điều trị bằng phác đồ hóa chất có chứa platin và $146 \mathrm{BN}$ điều trị bằng phác đồ không chứa platin. Kết quả cho thây nhóm BN điều trị bằng platin có thời gian sống thêm bệnh không tiến triển (PFS) dài hơn so với nhóm BN còn lai (7.8 tháng so với 4.9 tháng, $p<0.001$ ). Tỉ lệ đáp ứng toàn bộ ở nhóm được điều trị bước 1 bằng platin cũng cao hơn so với nhóm không dùng platin (57,3\% so với 32,9\%) [5].

Hiện nay, tại Việt Nam cũng có nhiều bệnh nhân UTV BBAT tái phát di căn được điều trị bằng phác đồ có chứa platin nhưng chưa có tác giả nào nghiên cứu đánh giá hiệu quả điều trị của phác đồ trên. Vì vậy, chúng tôi tiến hành nghiên cứu: "Đánh giá kêt quả điều trị bằng phác đồ hóa chất chứa platin trên bệnh nhân ung thư biêu mô tuyến vú có bộ ba âm tính tái phát di căn"

\section{II. ĐỐI TƯợNG VÀ PHƯƠNG PHÁP NGHIÊN CỨU}

1.Đối tượng nghiên cứu. Bệnh nhân nữ được chẩn đoán xác định là ung thư vú có bộ ba thụ thể $E R, P R$ và Her-2 âm tính tái phát di căn, được điều trị bằng phác đồ hóa chất chứa platin từ 01/2014 tới 03/2021.

\subsection{Tiêu chuẩn lứa chon:}

- Bênh nhân nữ được chẩn đoán xác định ung thư biếu mô tuyến vú bằng xét nghiệm mô bệnh học.

- Có kết quả nhuộm hóa mô miễn dịch đánh giá thụ thể nội tiết $E R, P R$ và Her-2 âm tính của tổn thương u ban đâu hay tổn thương tái phát di căn.
- Đã được điều trị triệt căn cho giai đoạn tại chỗ, tại vùng bằng các các phương pháp phấu thuật, hoá chất, xạ trị, nội tiết, điều trị đích theo chỉ định hoặc ung thư vú giai đoạn IV đã hoặc chưa điều trị hoá chất, không có chỉ định điều trị tại chỗ tại vùng.

- Chẩn đoán tái phát di căn bằng chẩn đoán hình ảnh hoă̆c tế bào học hoặc mô bệnh học.

- Được điều trị phác đồ hóa chất gemcitabine - carboplatin hoặc paclitaxel - carboplatin ít nhất 3 chu kỳ.

- Có tổn thương đánh giá được đáp ứng theo tiêu chuẩn RECIST.

- Chỉ số toàn trạng ECOG $\leq 2$.

- Chức năng gan thâan tủy xương trong giới hạn cho phép điều trị hóa chất

\subsection{Tiêu chuẩn loại trừ:}

- Bệnh nhân di căn não.

- Bểnh nhân đang mắc các bệnh cấp và mạn tính trẩm trong khác.

- Bệnh nhân dị ứng với thuốc.

- Bệnh nhân ngừng điều trị thuốc không phải vì lý do bệnh tiến triển, độc tính, kết thúc nghiên cứu.

- Bệnh nhân có ung thư nguyên phát tại cơ quan khác.

\section{Phương pháp nghiên cứu}

2.1. Thiết kế nghiên cứu. Nghiên cứu mô tả hồi cứu

2.2. Cỡ mẫu nghiên cứu. Áp dụng công thức tính cỡ mẫu cho việc ước tính một tỷ lệ:

$$
n=Z_{1-\propto / 2}^{2} \frac{p \cdot(1-p)}{(p \cdot \varepsilon)^{2}}
$$

Trong đó: n: cõ̃ mẫu tối thiểu cần đạt được trong nghiên cứu

Z: hệ số tin cậy, với $a=0,05$ tra bảng $Z=1,96$

$\mathrm{p}$ : tỷ lệ đáp ứng của nghiên cứu tương tự trước đó, $\mathrm{p}=0,57[5]$.

ع: giá trị tương đối, thường chọn trong khoảng $(0,1-0,4)$. Chọn $\varepsilon=0,25$

Ước tính cõ mẫu tối thiểu trong nghiên cứu cần phải đạt được là 46 bệnh nhân.

2.3. Phác đồ điêu trị: Bệnh nhân sau khi được chẩn đoán tái phát di cắn có đầy đủ các tiêu chuẩn trên được điều trị bằng hóa chất theo 1 trong 2 phác đồ:

- Phác đồ paclitaxel-carboplatin, chu kỳ 3 tuần.

Paclitaxel $175 \mathrm{mg} / \mathrm{m}^{2}$ - carboplatin AUC 5-6. Nhắc lại mỗi đợt sau 21 ngày

- Phác đồ gemcitabine - carboplatin, chu kỳ 3 tuân.

Gemcitabine $1000 \mathrm{mg} / \mathrm{m}^{2}$ da truyền tînh mạch ngày 1 và 8 . Carboplatin AUC 5-6, truyền tĩnh mạch ngày 1 . Nhắc lại mỗi đợt sau 21 ngày.

Đánh giá độc tính của phác đồ: Độc tính trên huyết học và độc tính trên thần kinh ngoại 
biên (Theo NCI-CTCAE 5.0)

Đánh giá đáp ứng điêu trị: sau 3 chu kì, theo RECIST 1.1 [6] gồm: Đáp ứng hoàn toàn, Đáp ứng 1 phần, Bệnh ổn định, Bệnh tiến triển.

Đánh giá thời gian sống thêm bệnh không tiến triển (PFS): là khoảng thời gian từ lúc bệnh nhân bắt đầu được điều trị cho tới thời điểm xác định bệnh tiến triển hoặc bệnh nhân tử vong.

3. Đạo đức nghiên cứu: Nghiên cứu đã được thông qua tại Hội Đồng Đạo đức Bệnh viện K.

\section{KẾT QUẢ NGHIÊN CỨU}

1. Một số đặc điểm của đối tượng nghiên cứu. Kết quả cho thấy trong tổng số 56 bệnh nhân tham gia nghiên cứu, tuổi trung bình của các đối tượng nghiên cứu là 49,2, thấp nhất là 25 tuổi, cao nhất là 71 tuổi. Các bệnh nhân trong nghiên cứu phần lớn ở giai đoạn II và III tại thời điểm chẩn đoán ban đầu, chiếm $79,6 \%$, có 1 bệnh nhân nào ở giai đoạn I chiếm $1,8 \%$. Trong số 56 bệnh nhân có 16 bệnh nhân ở giai đoạn IV ngay từ lần chẩn đoán đầu tiên, chiếm 28,6\%. Trong nghiên cứu của chúng tôi, phần lớn các bệnh nhân thuộc thể ung thư biểu mô xâm nhập típ không đặc biệt (NST), chiếm 78,6\%, 5 bệnh nhân ung thư biểu mô biểu thuỳ xâm nhập chiếm 8,9. Trong số 40 bệnh nhân trong nhóm nghiên cứu được chẩn đoán bệnh ở giai đoạn tại chỗ, tại vùng sau khi điều trị triệt căn, thời gian xuất hiện tái phát di căn hay gặp là sau 2 năm đầu chiếm $82,5 \%$. Trung bình thời gian sống thêm không bệnh là 16,3 tháng, ngắn nhất là 3 tháng, dài nhất là 51 tháng. Các vị trí di căn thường gặp trong nghiên cứu của chúng tôi lần lượt là phổi, gan và xương chiếm tỉ lệ lần lượt là $48,2 \%, 28 \%$ và $25 \%$.

Trong 56 bệnh nhân được điều trị bằng phác đồ chứa platin, có 20 bệnh nhân được điêu trị bằng phác đồ paclitaxel - carboplatin chiếm 35,7\%, 36 bệnh nhân được điều trị bằng phác đồ gemcitabine - carboplatin chiếm 64,3\%. Có 40 bệnh nhân được điều trị phác đồ chứa platin bước 1 , chiếm 71,4 và 16 bệnh nhân nhận điều trị phác đồ chứa platin bước 2 , chiếm $28,6 \%$.

Bảng 1: Một số đặc điểm của đối tượng nghiên cứu

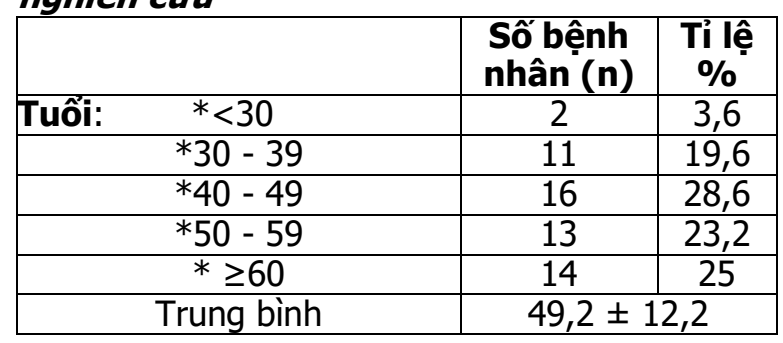

\begin{tabular}{|c|c|c|}
\hline \multicolumn{3}{|c|}{ Giai đoạn ban đâuu } \\
\hline *Giai đoạn I & 1 & 1,8 \\
\hline *Giai đoạn II & 20 & 35,7 \\
\hline *Giai đoạn III & 19 & 33,9 \\
\hline *Giai đoạn IV & 16 & 28,6 \\
\hline \multicolumn{3}{|c|}{ Mô bệnh học } \\
\hline *UTBM xâm nhập NST & 44 & 78,6 \\
\hline *UTBM tiếu thùy xầm nhập & 5 & 8,9 \\
\hline *UTBM thế dị sản & 3 & 5,4 \\
\hline *UTBM thê tủy & 2 & 3,6 \\
\hline *Khác ${ }^{1}$ & 2 & 3,6 \\
\hline Độ mô học : *Độ 1 & 1 & 2,4 \\
\hline *Độ 2 & 26 & 63,4 \\
\hline *Độ 3 & 14 & 34,1 \\
\hline \multicolumn{3}{|c|}{ Tình trạng Ki-67 } \\
\hline$* \mathrm{Ki}-67<20$ & 10 & 17,9 \\
\hline *Ki-67 $\geq 20 \%$ & 46 & 82,1 \\
\hline \multicolumn{3}{|c|}{ Vị trí tái phát di căn } \\
\hline *Tại chô tại vùng & 11 & 19,6 \\
\hline *Hạch trung thất, ô bụng & 12 & 21,4 \\
\hline *Xương & 14 & 25,0 \\
\hline *Gan & 16 & 28,0 \\
\hline *Phối & 27 & 48,2 \\
\hline *Khác ${ }^{3}$ & 4 & 7,1 \\
\hline \multicolumn{3}{|c|}{ Di căn tạng } \\
\hline *Không di căn tạng & 18 & 32,1 \\
\hline *Di căn tạng (gan hoặc phối) & 34 & 60,7 \\
\hline \multicolumn{3}{|l|}{ CA 15-3 } \\
\hline *Trong giới hạn bình thường & 29 & 51,8 \\
\hline *Tăng cao hơn bình thường & 27 & 48,2 \\
\hline \multicolumn{3}{|c|}{ Phác đồ điều trị tái phát di căn } \\
\hline *Paclitaxel - carboplatin & 20 & 35,7 \\
\hline *Gemcitabine - carboplatin & 36 & 64,3 \\
\hline \multicolumn{3}{|c|}{ Điêu trị hóa chất bước } \\
\hline *Bước 1 & 40 & 71,4 \\
\hline *Bướ & 16 & 28,6 \\
\hline
\end{tabular}

\section{Chú thích:}

${ }^{1}$ Gồm 1 bệnh nhân ung thư biểu mô thể nhẫn và 1 bệnh nhân ung thư biểu mô thể vi nhú.

${ }^{2}$ Trong số 41 bệnh nhân UTBM xâm nhập NST

3 Gồm 1 BN di căn hạch thượng đòn đối bên, 1 di căn hạch chậu, 1 BN di căn màng phổi

4. Đáp ứng với điều trị và 1 số yếu tố liên quan. Trong số 56 bệnh nhân nghiên cứu, sau 3 đợt điều trị, có 30 bệnh nhân ghi nhận đáp ứng, chiếm $53,6 \%$, trong đó không có bệnh nhân nào đáp ứng hoàn toàn. Tỷ lệ đáp ứng chung của phác đồ là $58,9 \%$, trong đó tỷ lệ đáp ứng hoàn toàn là $10,7 \%$. Có $12,5 \%$ bệnh nhân đạt bệnh giữ nguyên, như vậy lợi ích lâm sàng đạt $71,4 \%$. Có 16 bệnh nhân tiến triển ngay sau 3 chu kỳ điều trị chiếm $28,6 \%$. Tỷ lệ đáp ứng ở nhóm bệnh nhân điêu trị phác đồ bước 1 là 67,5\%, cao hơn so với nhóm bệnh nhân điều trị 
phác đồ này ở bước 2 là 37,5\%, sự khác biệt có ý nghĩa thống kê với $p=0,039$. Nhìn chung, đáp ứng của phác đồ phần lớn đạt được sau 3-6 đợt điều trị. Không có sự khác nhau giữa tỉ lệ đáp ứng điều trị với cá yếu tố liên quan như thể mô bệnh học, độ mô học, mức độ độ bộc lộ Ki-67, vị trí di căn hay việc lựa chọn phác đồ điều trị gemcitabine - carboplatin hay paclitaxel carboplatin $(p>0,05)$.

Bảng 2: Mối liên quan giữa tỉ lệ đáp ứng với các yêu tố liên quan

\begin{tabular}{|c|c|c|c|c|c|}
\hline \multirow[t]{2}{*}{ 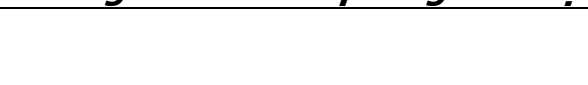 } & \multicolumn{2}{|c|}{ Bệnh đáp ứng } & \multicolumn{2}{|c|}{ Bệnh không đáp ứng } & \multirow[b]{2}{*}{$\mathbf{p}$} \\
\hline & n1 & $\%$ & n2 & $\%$ & \\
\hline Độ mô học: *Độ 1 & 1 & 100 & 0 & 0 & \multirow{3}{*}{$p=0,097$} \\
\hline *ंĐộ 2 & 19 & 65,4 & 7 & 34,6 & \\
\hline *Đố 3 & 5 & 35,7 & 9 & 64,3 & \\
\hline Tống & 33 & 56,1 & 23 & 43,9 & \\
\hline \multicolumn{6}{|l|}{ Mô bệnh học } \\
\hline UTBM xâm nhập NST & 23 & 56,1 & 18 & 43,9 & \\
\hline UTBM tiếu thùy xâm nhập & 4 & 66,7 & 2 & 33,3 & $p=0,828$ \\
\hline Loại khác & 6 & 66,7 & 3 & 33,3 & \\
\hline Tống & 39 & 58,9 & 17 & 44,1 & \\
\hline Tình trạng Ki-67: *Ki-67 < 20\% & 7 & 70 & 3 & 30 & $p=0.500$ \\
\hline$*_{\mathrm{Ki}-67} \geq 20 \%$ & 26 & 56,5 & 20 & 43,5 & \\
\hline Tống & 33 & 58,9 & 23 & 41,1 & \\
\hline \multicolumn{6}{|l|}{ Tình trạng di căn tạng } \\
\hline *Có di cắn tạng & 22 & 57,9 & 16 & 42,2 & $p=1,000$ \\
\hline *Không di căn tạng & 11 & 61,1 & 7 & 38,9 & \\
\hline Tổng & 39 & 58,9 & 17 & 41,1 & \\
\hline \multicolumn{6}{|l|}{ Phác đồ điêuu trị } \\
\hline *Paclitaxel - carboplatin & 14 & 70 & 6 & 30 & \\
\hline *Gemcitabine - carboplatin & 19 & 52,8 & 17 & 47,2 & $p=0,209$ \\
\hline Tống & 33 & 58,9 & 23 & 41,1 & \\
\hline Điều trị bước: *Bước 1 & 14 & 70 & 6 & 30 & \\
\hline *Bước 2 & 19 & 52,8 & 17 & 47,2 & $p=0,209$ \\
\hline Tống & 33 & 58,9 & 23 & 41,1 & \\
\hline
\end{tabular}

5.Thời gian sống thêm không tiến triển của bệnh nhân. Thời gian trung bình sống thêm không tiến triển là 6,97 tháng. Tối thiểu là 3 tháng, tối đa là 18 tháng. Trung vị sống thêm bệnh không tiến triển là 7,0 $\pm 0,5$ tháng. Tỷ lệ sống thêm không bệnh tiến triển tại thời điểm 3 tháng và 6 tháng và 9 tháng lần lượt là: $83,9 \%$, $58,8 \%$ và $5,5 \%$

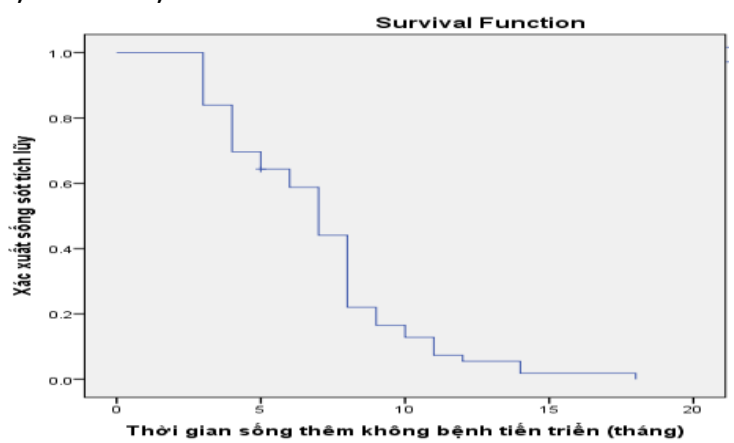

Biểu đồ 3.7. Thời gian sống thêm không bệnh tiến triển (PFS)
Bảng 2: Môi liên quan giữa PFS với các yếu tố liên quan

\begin{tabular}{|c|c|c|c|}
\hline & $\begin{array}{c}\text { Trung vị } \\
\text { (tháng) }\end{array}$ & $\begin{array}{c}\text { 95\% } \\
\text { khoảng tin } \\
\text { cậy(tháng) }\end{array}$ & p \\
\hline \multicolumn{4}{|c|}{ Phác đồ hóa chất } \\
\hline $\begin{array}{c}\text { *Paclitaxel - } \\
\text { carboplatin }\end{array}$ & 8 & $7,4-8,6$ & 0,154 \\
\hline $\begin{array}{c}\text { *Gemcitabine } \\
\text { - carboplatin }\end{array}$ & 6 & $4,4-7,6$ & \\
\hline \multicolumn{4}{|c|}{ Điêuu trị bước } \\
\hline *Bước 1 & 7 & $6,3-7,7$ & 0,746 \\
\hline *Bước 2 & 4 & $2,1-5,9$ & \\
\hline \multicolumn{4}{|c|}{ Vị trí di căn } \\
\hline $\begin{array}{c}\text { *Không di căn } \\
\text { tạng }\end{array}$ & 8 & $6,9-9,1$ & 0,976 \\
\hline $\begin{array}{c}\text { *Có di căn } \\
\text { tạng }\end{array}$ & 7 & $6,0-8,0$ & \\
\hline
\end{tabular}

4. Độc tính. Độc tính của phác đồ thường gặp chủ yếu là độ 1, 2. Các độc tính thường gặp là hạ bach cầu hạt $(63,5 \%)$, hạ huyết sắc tố $(50 \%)$, hạ tiểu cầu $(26,8 \%)$, rụng tóc $(46,4 \%)$, nôn và buồn nôn $(51,7 \%)$ 


\section{BÀN LUÂN}

Kết quả của chúng tôi cho thấy tỷ lê đáp ứng chung của phác đồ là $58,9 \%$, trong đó tỷ lệ đáp ứng hoàn toàn là $10,7 \%$, tỷ lệ đáp ứng ở nhóm bệnh nhân điều trị phác đồ bước 1 và bước 2 lần lượt là là $67,5 \%$ và $37,5 \%$. Kết quả của chúng tôi cao hơn nghiên cứu của Zhang (2015) với tỉ lệ đáp ứng bước 1 là $57,7 \%$ đồng thời cũng cao hớn nghiên cứu của Chen và cộng sự (2020) với lệ đáp ứng toàn bộ là $49 \%$ trong đó tỉ lệ đáp ứng toàn bộ của điều trị tại bước 1 , bước 2 , và bước 3 lần lượt là 53\%, 26,7\%, 26,7\% [5] [7].

Có sự khác biệt này có thể là bệnh nhân trong nghiên cứu của tác giả Zhang và Chen bao gồm cả nhóm bệnh nhân di căn não, đây là nhóm bệnh nhân có tỉ lệ đáp ứng điều trị kém hơn so với những bệnh nhân có vị trí di căn khác.

Trong nghiên cứu của chúng tôi, thời gian sống thêm không bệnh tiến triển trung bình là 6,97 tháng, ngắn nhất là 3 tháng, dài nhất là 18 tháng. Trung vị sống thêm không tiến triển là 7,0 $\pm 0,5$ tháng. Kết quả của chúng tôi thấp hơn nghiên cứu của Zhang và cộng sự (2015) với PFS là 7,8 tháng [5]. Tương tự, nghiển cứu của Chen và cộng sự 2020 với trung vị PFS là 8,4 tháng [7]. Điều này có thể giải thích do các bệnh nhân trong nghiên cứu của chúng tôi có tỉ lệ di căn tạng lớn hơn, tî lệ di căn xương và tái phát tại chố tại vùng thấp hơn. Đây là một trong những yếu tố tiên lượng xấu ảnh hưởng đến kết quả điều trị.

Đánh giá về độc tính của phác đồ, nghiên cứu của chúng tôi thường gặp chủ yếu là độc tính độ 1, 2. Các độc tính thường gặp là ha bạch cầu hạt $(63,5 \%)$, hạ huyết sắc tố $(50 \%)$, hạ tiểu cầu $(26,8 \%)$, rụng tóc (46,4\%), nôn và buồn nôn (51,7\%).

\section{KẾT LUẬN}

Sự phối hóa chất dựa trên nền tảng platin đem lại hiệu quả về tỉ lệ đáp ứng và thời gian sống thêm bệnh không tiến triển cao cho bệnh nhân UTV BBAT tái phát hoặc di căn. Tuy nhiên cần đánh giá và theo dõi sát độc tính của phác đồ trong quá trình điều trị.

\section{TÀI LIỆU THAM KHẢO}

1. CA: A Cancer Journal for Clinicians. American Cancer Society Journals, $<$ https://acsjournals.onlinelibrary.wiley.com/journa 1/15424863>, accessed: 30/05/2021.

2. Kaya V., Yilldirim M., Yazici G. và cộng sự. (2018). Effectiveness of Platinum-Based Treatment for Triple Negative Metastatic Breast Cancer: a Meta-Analysis. Asian Pac J Cancer Prev APJCP, 19(5), 1169.

3. Brouckaert 0 ., Wildiers H., Floris G. và công sự. (2012). Update on triple-negative breast cancer: prognosis and management strategies. Int J Womens Health, 4, 511-520.

4. Dent R., Trudeau M., Pritchard K.I. và cộng sư. (2007). Triple-negative breast cancer: clinical features and patterns of recurrence. Clin Cancer Res Off J Am Assoc Cancer Res, 13(15 Pt 1), 4429-4434.

5. Zhang J., Fan M., Xie J. và cộng sự. (2015). Chemotherapy of metastatic triple negative breast cancer: Experience of using platinum-based chemotherapy. Oncotarget, 6(40), 43135-43143.

6. Eisenhauer E.A., Therasse P., Bogaerts J. và cộng sự. (2009). New response evaluation criteria in solid tumours: Revised RECIST quideline (version 1.1). Eur J Cancer, 45(2), 228-247.

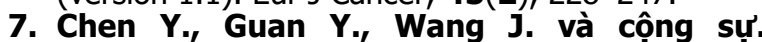
(2020). Platinum-based chemotherapy in advanced triple-negative breast cancer: A multicenter real-world study in China. Int J Cancer, 147(12), 3490-3499.

\section{BÁO CÁO CA BỆNH: HộI CHỨNG EKBOM}

\section{Phùng Thị Thúy Hằng ${ }^{1}$, Lê Việt Sơnn ${ }^{1}$, Nguyễn Thị Thanh Tâm¹, Nguyễn Thị Phương Loan ${ }^{2}$, Vũ Văn Hoài ${ }^{2}$, Nguyễn Thị Phương ${ }^{3}$, Nguyễn Văn Giáp ${ }^{3}$, Phạm Văn Thích ${ }^{3}$, Bùi Văn $\mathrm{San}^{3}$}

\section{TÓM TẮT}

\author{
${ }^{1}$ Bênh viện Bạch Mai \\ ²Viện Sức khoẻ Tâm thần, Bệnh viện Bạch Mai \\ ${ }^{3}$ Đại họ Y Hà Nội \\ Chịu trách nhiệm chính: Bùi Văn San \\ Email: buivansan@hmu.edu.vn \\ Ngày nhận bài: 16.8 .2021 \\ Ngày phản biên khoa hoc: 14.10.2021 \\ Ngày duyệt bài: 25.10 .2021
}

Bệnh nhân nữ 53 tuổi, vào viện vì: Tổn thương mắt - luôn cho rằng có những côn trùng cắn trên da. Bệnh biểu hiện khoảng 03 năm nay, bênh nhân mô tả nhìn thấy "con ghẻ" màu trắng hình dạng như hạt gạo có chân bò khắp người bệnh nhân. Bệnh nhân đi khám, điều trị chuyên khoa Da Liễu nhiều nơi nhưng tình trạng trên không đõ. Khoảng 03 tháng nay bệnh nhân cảm giác con này thường xuyên bò vào tai vào mũi, vào mắt cắn ở trong mắt, bệnh nhân đi khám và điêu trị tại Bệnh viên mắt TW, khoa Mắt Bệnh viện Bạch Mai, được làm xét nghiệm, khám lâm sàng chẩn đoán: viêm củng giác mạc hoại tử - đái tháo đường - 
tăng huyết áp. Trong quá trình điều trị bệnh nhân thường xuyên dùng bông cồn chấm lau mắt, dung kim lẩy da và kết giác mạc với mục đích bắt ghẻ côn trùng chui vào mắt, thườing xuyên tự dùng thuốc không theo chỉ định, bệnh nhân còn than phiền nhiều các biểu hiện trên mời hội chẩn chuyên khoa Tâm thần chẩn đoán theo dõi Rối loạn cơ thể hóa/ Viêm loét giác mạc củng mạc hoại tử - Tăng huyết áp - đái tháo đường. Bệnh nhân được điều chỉnh chế độ ăn, thăm khám và chăm sóc mắt, thuốc Fluvoxamine $200 \mathrm{mg} /$ ngày và Quetiapine $400 \mathrm{mg} / \mathrm{ngày}$. Sau 15 ngày điều tri bệnh thuyên giảm đước ra viện và hẹn khám lại sau 1 tháng.

Tư khoá: Hôi chứng Ekbom, xâm nhiễm ký sinh trùng, hoang tưởng nghi bệnh, viêm hoại tử nhãn cầu, tự gây tổn thương mắt,

\section{SUMMARY}

\section{CASE REPORT: EKBOM SYMPTOMS}

A 53-year-old female patient, admitted to the hospital because of eye damage, always believes that there are insect bites on her skin. The disease has been present for about 3 years, the patient described seeing a white "scabies" shaped like a rice grain with legs crawling all over the patient's body, the patient said that he had gone to many places for dermatology and treatment, but the above condition did not improve. About 3 months ago, the patient noticed that this insect often crawled into the ear, into the nose, into the eye biting in the eye, the patient went for examination and treatment at the Central Eye Hospital, the Eye Department of Bach Mai Hospital, was tested. Her diagnosis: necrotizing scleritis diabetes - hypertension. During the course of treatment, patients often use antiseptic cotton (alcohol) to wipe their eyes, use needles to prick the skin and conjunctival conjunctiva for the purpose of catching insect mites entering the eyes, often selfadministering drugs not prescribed. Patients also complained of many of the above symptoms, invited to consult a the Psychiatrist's department to diagnose Somatization disorder / necrotizing scleritis Hypertension - diabetes. Patients were adjusted to diet, examination and eye care, Fluvoxamine $200 \mathrm{mg} /$ day and Quetiapine $400 \mathrm{mg} /$ day. After 15 days of treatment, the disease was in remission and was discharged from the hospital and scheduled to be reexamined after 1 month.

Key words: Ekbom syndrome, parasitic infections, delusional suspected disease, necrotizing scleritis, selfinjurious to the eye

\section{I. ĐĂT VẤN ĐỀ}

Hội chứng Ekbom (Ekbom's syndrome: ES) có thể được gọi là hoang tưởng bị nhiễm ký sinh trùng, chứng sợ ký sinh trùng xâm nhập da hoặc chứng sợ các loại bọ bò trên da. Những thuật ngữ này đã được sử dụng để mô tả một nhóm các rối loạn tâm thần đặc trưng bởi niềm tin kì quái và lặp đi lặp lại rằng cơ thể của một người bị xâm nhiễm bởi ký sinh trùng, côn trùng, giun, sinh vật nhỏ hoặc thậm chí các vật thể (như là sợi, hạt, tinh thể; còn gọi là 'bệnh Morgellons'), trong trường hợp không có bất kỳ bằng chứng khách quan nào ủng hộ niềm tin đó. ${ }^{1}$

Bằng chứng dịch tể học cho thấy rằng $\mathrm{ES}$ là một tình trạng tương đối phổ biến với tỷ lệ nữ /nam dao động từ 2: 1 đến 3: 1, tuy nhiên có thể được điều trị bởi các bác sĩ chuyên khoa khác nhau, tình trạng bệnh này thường không được đánh giá chính xác ở các cơ sở tâm thần. Hội chứng này thường mắc ở các đối tượng trung niên hoặc cao tuổi. Tỷ lệ hiện mắc được ước tính từ $0,18-4,2$ trên 100.000 người, với tỷ lệ mắc là 1,9 trên 100.000 , tuy nhiên, sự dao động của nó rất rộng: như ở Vương quốc Anh, tỷ lệ mắc bệnh ước tính là khoảng 4,9 phần triệu. ${ }^{2}$

James Harrington (1611-1677), nhà lý luận chính trị và học giả người Anh, tranh luận với Lyell (Bác sĩ da liễu) về triệu chứng rằng mồ hôi của anh biến thành ruồi và đôi khi là ong và các loài côn trùng khác, là biểu hiện đầu tiên được ghi nhận của chứng hoang tưởng ký sinh trùng.

Năm 1938, Ekbom công bố một báo cáo trường hợp trên tạp chí Acta Psychiatrica et Neurologica Scandinavica - Praeseniler Dermatzooenwahn - báo cáo 8 bệnh nhân hoang tưởng rằng họ bị nhiễm ký sinh trùng trên $\mathrm{da}^{3}{ }^{3}$

Trong quá trình làm việc thực hành lâm sàng chúng tôi nhận thấy ca bệnh biểu hiện tổn thương tại mắt, da và tâm thần. Sau một thời gian điêu trị tại nhiều viện chuyên khoa, bệnh nhân được chuyển đến điều trị tại Viện Sức khỏe Tâm thần (VSKTT)- bệnh viện Bạch Mai, chúng tôi có tiếp nhận và hội chẩn chuyền khoa một số trường hợp có những triệu chứng như trên, do đó chúng tôi trình bày một ca bệnh.

\section{TRÌNH BÀY CA LÂM SÀNG}

Bệnh nhân nữ 53 tuổi, vào viện vì: Tổn thương mắt - luôn cho rằng có những côn trùng cắn trên da

Bênh sử: Theo lời kể của bệnh nhân và em gái

Bệnh nhân có tiền sử sản nhi khoa bình thường, phát triển tâm thần, vận động như các bạn cùng lứa tuổi. Bệnh nhân không có tiền sử dùng các chất gây nghiện, không có tiền sử bệnh lý nội khoa, gia đình không ai mắc rối loạn tâm thần. Tính cách: bệnh nhân là người trâm tính, ít nói. Bênh nhân trước đây học lớp 7/10 học lực trung bình, do điều kiện gia đình khó khan nển bệnh nhân nghỉ học sớm. Bệnh nhân sau khi học xong thì ở nhà phụ giúp gia đình việc nội trợ và làm đồng ruộng. Sau đó bệnh nhân lập gia đình, ở nhà làm ruộng và làm thủ công ở nhà, có 2 người con, các con ngoan ngoãn khỏe mạnh hiện đã lập gia đình riêng. Gia đình bênh nhân hòa thuận, kinh tế gia đình trung bình, bệnh nhân 
không có mâu thuẫn với ai.

Bệnh biểu hiện khoảng 03 năm nay, bệnh nhân có người cổ hàng xóm chăn nuôi gia súc, gia cầm nhiều, thường xuyên sang nhà bệnh nhân chơi. Cùng thời gian đó, người này có biểu hiện thường xuyên ngứa chân tay, người này thường cùng nằm một chỗ với bênh nhân để xem ti vi. Sau đó bệnh nhân xuất hiện ngứa đầu vùng thái dương bên trái, bệnh nhân ban đầu cho rằng mình bị ngứa là do lây của người hàng xóm, bệnh nhân ban đầu chỉ xoa nhẹ trên da cho bớt ngứa, càng về sau mức độ ngứa càng nhiều hơn. Kèm theo đó bệnh nhẩn cảm thấy như có con gì đó bò trên da, thi thoảng cắn vào da. Bênh nhân cảm thấy bứt rứt khó chiu và mô tả nhìn thấy "con ghẻ" màu trắng hình dạng như hạt gạo có chân bò khắp người. Bệnh nhân kể đi khám chuyên khoa Da Liễu, yêu cầu bác sĩ dùng dụng cụ gắp con này ra khỏi da bệnh nhân, làm xét nghiệm, làm thủ thuật, bệnh nhân thường xuyên phải xoa, gãi khắp người để đẩy con này ra khỏi da, bệnh nhân chỉ cho mọi người "con ghẻ" này để chứng minh nhưng không có ai thấy. Bệnh nhân trong 3 năm đi khám và điều trị chuyên khoa da liễu nhiều nơi nhưng tình trạng trên không đỡ, bệnh nhân về nhà tự cách ly với người thân vì sợ lây bệnh cho người thân, đốt hết quần áo, chăn màn bàn ghế cũ. Khoảng 03 tháng nay bệnh nhân cảm giác con này thường xuyên bò vào tai vào mũi, vào mắt cắn ở trong mắt bệnh nhân, bệnh nhân đưa tay lên xoa dụi mắt nhiều, tự tra thuốc vào mắt, bệnh nhân thấy mắt đỏ nhiều, chảy dịch bệnh nhân đi khám và điều trị tại Bệnh viên mắt trung ương, sau đó bệnh nhân phát hiện tăng huyết áp, đái tháo đường. Tình trạng mắt bệnh nhân chảy dịch mủ nhiêu, mờ mắt tăng dần, hiện tại bệnh nhân chỉ phân biệt được sáng tối, đêm bệnh nhân ngủ được, mỗi khi thức dậy tình trạng khó chịu trên da, trong mắt, trong tai, trong mũi lại xuất hiện làm bệnh nhân khó chịu nhiều. Bệnh nhân được chuyển đến khoa Mắt Bệnh viện Bạch Mai, được làm xét nghiệm, khám lâm sàng chẩn đoán: viêm củng giác mạc hoại tử - đái tháo đườngtăng huyết áp. Khi vào khoa điều trị bênh nhân được tiến hành lấy xét nghiệm nuôi cấy vi khuẩn tại mắt phát hiện bệnh nhân để bông cồn trong mắt dẫn đến viêm hoại tử nhãn cầu (tự gây tổn thương mắt). Trong quá trình điều trị bệnh nhân thường xuyên dung bông cồn chấm lau mắt, dùng kim lẩy da và kết giác mạc với mục đích bắt ghẻ côn trùng chui vào mắt, thường xuyên tự dùng thuốc không theo chỉ định, bệnh nhân còn than phiên nhiều các biểu hiện trên mời hội chẩn chuyên khoa Tâm thần. Sau đó bệnh nhân được chuyển sang Viện Sức khỏe Tâm thần trong tình trạng, cho rằng trên người có nhiều "con ghẻ" bò trên người, cắn trên da, trong mắt không giải thích đả thông được, mắt phân biệt sáng tối, chảy ít dịch đục.

Tiên sử: Bản thân: Không có tiền sử rối loạn sức khỏe tâm thần

Tính cách: vui vẻ hòa đồng, không hay lo nghĩ, căng thẳng

Không có tiền sử dị ứng

Gia đình: không ai mắc bệnh tâm thần, động kinh, di truyền

Chồng và các con đi làm xa không thường xuyên ở nhà, chỉ có một mình bệnh nhân ở quê nhà.

Khám bệnh: Tâm thần: tỉnh, tiếp xúc tốt

Không rối loạn các năng lực định hướng

Cảm giác, tri giác: theo dõi ào giác xúc giác: Bênh nhân cảm thây có "con ghẻ" bò trên da, cắn trên da. Ảo giác thị giác: bệnh nhân miêu tả "con ghẻ" to bằng hạt gạo màu trắng có chân bò trên da.

Tư duy: theo dõi hoang tưởng nghi bệnh. BN cho rằng mình bị bệnh về da liểu, không chấp nhận giải thích của bác sĩ và người nhà vê bệnh và hành vi xoa da, đưa tay vào mũi vào tai, dụi mắt.

Cảm xúc: lo lắng nhiều, phàn nàn về bệnh, dễ cáu gắt khi giải thích tình trạng bệnh.

Hành vi: bị chi phối bởi hoang tưởng ảo giác, công việc lao động giảm sút, ăn ngủ kém, ít quan tâm tình dục.

Chú ý: giảm tập trung, giảm khả năng duy trì sự chú ý với các sự vật hiện tượng bên ngoài.

Trí nhớ, trí tuệ: bình thường.

Khám toàn thân: Thể trạng gầy: cao $1,55 \mathrm{~m}$, nặng $42 \mathrm{~kg}$, BMI: $17,5 \mathrm{~kg} / \mathrm{m}^{2}$

Lông tóc, móng bình thường

Các bộ phận khác:

Mắt: Bệnh nhân thị lực: phân biệt sáng tối,

2 mắt viêm loét giác mạc, củng mạc hoại tử, mắt trái loét thủng giác mạc tự bít, không khám được bán phần sau.

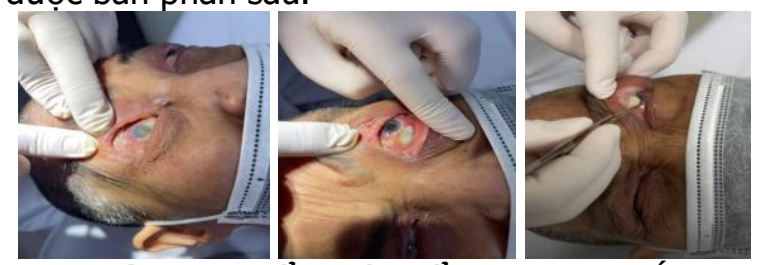

Hình 1: Biểu hiện tổn thương mắt

Tim mạch, hô hấp bình thường

Bụng không chướng, gan lách không sờ thấy

Các cơ quan khác chưa phát hiện bất thường

Chẩn đoán: Rối loạn cơ thể hóa/ Viêm loét giác mạc củng mạc hoại tử - Tăng huyết áp - đái 
tháo đường.

Cận lâm sàng: Làm các xét nghiệm cơ bản Cổng thức máu: Hồng cầu: 3.58 T/L, Hb: 111g/L Tiểu cầu: $547 \mathrm{G} / \mathrm{L}$

Bạch câu: $12.33 \mathrm{G} / \mathrm{L}$

Sinh hóa máu: Creatinin: $55 \mu \mathrm{mol} / \mathrm{L}$, ASTALT:15-12 U/L

CRP hs: $0.25 \mathrm{mg} / \mathrm{dL}$, HbA1C: $6.4 \%$

Vi sinh: HIV, HbsAg: âm tính

Toxoplasma IgG: âm tính

Kháng thể giun lươn, giun đũa chó mèo, sán

máng, sán lá gan lơn: âm tính

Cái ghẻ soi tươi: không thây kí sinh trùng

Vi khuẩn nuôi cấy định dạnh hệ thống (dịch mủ mắt): âm tính

Soi tươi tìm nấm: không thấy

Miễn dịch: Kháng thể kháng nhân, kháng dsDNA, kháng SS-A, SS-B: âm tính

Định lượng IgG, IgE, C3, C4: trong giới hạn bình thường

Siêu âm ổ bụng: Sỏi nhỏ túi mật, nang nhỏ thận phải

Cộng hưởng từ so não:

Mắt trái: thủng giác mạc và mất thủy tinh thể, giảm thể tích dịch kính, giảm kích thước nhãn câu.

Nhu mô não bình thường.

Quá trình điêuu trị: Bệnh nhân được khám, hội chuẩn chuyên khoa mắt sau đó chuyển chuyên khoa tâm thần. Tại chuyên khoa tâm thần được đánh giá về tâm thần và điều trị các triệu chứng.

Bệnh nhân được sử dụng thuốc:

Fluvoxamine $200 \mathrm{mg} / \mathrm{ngày}$ và Quetiapine $400 \mathrm{mg} / \mathrm{ngày}$.

Bệnh nhân ăn chế độ DD01 tại bênh viện

Trong quá trình điều trị bệnh nhân có những thay đổi về tình trạng tâm thần: bệnh nhân ngủ tốt hơn (7-9 tiếng/ngày), đõ than phiền về các khó chịu trên da, tần suất sử dụng các phương pháp lau mắt giảm.

Kèm theo tác động với người chăm sóc, gia đình yên tâm điều trị

Bệnh nhân được điều trị duy trì 15 ngày tiếp theo với phác đồ như trên và được ra viện, hẹn khám lại sau 1 tháng.

\section{BÀN LUÂN}

Hội chứng Eskbom là một chứng rối loạn tâm thần, trong đó các cá nhân có niềm tin dai dẳng rằng họ bị nhiễm các mầm bệnh sống hoặc không sống như ký sinh trùng, cổn trùng hoặc bo, khi khônng có biểu hiên khách quan đó. Ho thường báo cáo ảo giác xúc giác được gọi là cảm giác gần như kiến bò trên da, cảm giác giống như côn trùng bò trên hoặc dưới da.

Triệu chứng bện: Những người mắc chứng này tin rằng "ký sinh trùng, giun, ve, vi khuẩn, nấm" hoặc một số sinh vật sống khác đã gây bệnh cho họ và không thể giải thích khoa hoc để đả thông niềm tin này. Thông tin chi tiết khác nhau giữa những người mắc tình trạng này, thường biểu hiện cảm giác như kiến bò và châm chích, liên quan đến việc ký sinh trùng được cảm nhận bò lên hoặc chui vào da, đôi khi kèm theo cảm giác thực tế (đã biết như cảm giác gần như kiến bò trên da). Một số cá nhân có thể tự gây thương tích khi cố gắng loại bỏ "ký sinh trùng"; kết quả tổn thương da bao gồm trây da, vết bầm tím và vết cắt, cũng như tổn thương do sử dụng các chất hóa học và thói quen tẩy rửa ám ảnh. ${ }^{4}$

Các sự kiện như bị côn trùng cắn, đi du lịch, dùng chung quần áo, hoặc tiếp xúc với người bị nhiễm bệnh; những sự kiện như vậy có thể khiến cá nhân biểu hiện rõ hơn về các triệu chứng mà ho có thể bỏ qua trước đây. Gần như bất kỳ dấu vết nào trên da, hoặc vật thể hoặc hạt nhỏ được tìm thấy trên người hoặc quần áo của họ, đều có thể được hiểu là bằng chứng cho sự nhiễm ký sinh trừng và những cá nhân mắc bệnh thường buộc phải thu thập "bằng chứng" như vậy để trình bày cho các chuyên gia y tế. Trên bệnh nhân của chúng tôi có những triệu chứng xuất phát từ những người xung quanh (cô hàng xóm chăn bò), các diến biến tiếp xúc, phát sinh và quá trình tìm kiếm rất nhiều nơi. Thêm vào đó bệnh nhân tự giảm khó chịu gây ra những tổn thương không hồi phục ở mắt.

Hoang tưởng tương tự có thể xuất hiện ở những người thân ruột thịt - một tình trạng chung đước goi là folie à deux - xảy ra trong 15$25 \%$ trường hợp và được coi là một chứng hoang tưởng cảm ứng. ${ }^{5}$ Chúng tôi theo dõi tính chất của hoang tưởng nghi bệnh trên bệnh nhân, do quá trình các triệu chứng khó chịu ảnh hưởng đồng thời không giải thích được bởi các chuyên khoa có thể dẫn tới những cảm xúc, suy nghĩ về bệnh trên bệnh nhân này.

Nguyên nhân bênh: Nguyên nhân của hội chứng chưa được biết rõ. Nó có thể liên quan đến việc tăng dopamine trong thể vân của não, do suy giảm chức năng vận chuyển dopamine (DAT), điều chỉnh tái hấp thu dopamine trong não. Bằng chứng ủng hộ lý thuyết dopamine là các loại thuốc ức chế tái hấp thu dopamine (ví dụ như cocaine và amphetamine) được biết là gẩy ra các triệu chứng giống hội chứng này. Các điều kiện khác cũng chứng tỏ chức năng DAT bị 
giảm được biết là nguyên nhân gây ra hoang tưởng kí sinh trùng thứ cấp; những tình trạng này bao gồm "tâm thần phân liệt, trầm cảm, chấn thương sọ não, lạm dụng rượu, bệnh Parkinson và Huntington, nhiếm vi rút gây suy giảm miễn dịch ở người, thiếu sắt". Bằng chứng nữa là thuốc chống loan thần cải thiện các triệu chứng của $E S$, có thể là do chúng ảnh hưởng đến sự truyền dopamine. ${ }^{4}$

Trền bệnh nhân này chúng tôi chưa có đủ điều kiện làm những xét nghiệm chất dẫn truyền những xét nghiệm chuẩn đoán phân biệt với một bệnh cơ thể chúng tôi làm tối đa có thể trong các phương pháp sằn có tại Bệnh viện Bạch Mai

Chẩn đoán: ES được chẩn đoán khi hoang tưởng là biểu hiện chính của rối loạn tâm thần, cơn hoang tưởng đã kéo dài một tháng hoăc lâu hơn, hành vi không có gì kỳ lạ hoặc suy giảm rõ rệt, rối loạn cảm xúc, nếu có thì tương đối ngắn và hoang tưởng không thể được giải thích rõ hơn về tình trạng bệnh lý khác, rối loạn tâm thần hoặc tác động của một chất nào đó. Để chẩn đoán, cá nhân phải quy kết những cảm giác bất thường trên da là do họ bị nhiễm trùng và tin chắc rằng họ bị nhiễm kí sinh trùng ngay cả khi bằng chứng cho thây họ không bị nhiễm bệnh.

Khám, xét nghiệm để loại trừ các tình trang khác giúp xây dựng mối quan hệ tin cậy với bác sĩ; điêuu này có thể bao gồm phân tích trong phòng thí nghiệm như công thức máu, tốc độ máu lắng, CRP, phân tích nước tiểu để tìm chất độc và hormone tuyến giáp, ngoài ra còn có sinh thiết da và xét nghiệm da liễu để phát hiện hoặc loại trừ là yếu tố quyết định chẩn đoán. ${ }^{6}$

Ngoài chẩn đoán tổn thương tại mắt, các triệu chứng ban đâu chúng tôi đưa ra phù hợp với một Rối loạn cơ thể hoá (F45.0 - ICD 10) do những than phiền về triệu chứng cơ thể, tìm kiếm nhiều phương pháp thăm khám, không giải thích bằng các xét nghiệm cũng như thăm khám phù hợp với bệnh. Tuy vậy khi đánh giá kết hợp thì trên bệnh nhân này có những điểm khác: các cảm giác về ký sinh trùng là chủ yếu, các tìm kiếm và phương thức nhằm loại bỏ chúng dẫn tới những hậu quả lớn (hoại tử nhãn cầu). Chúng tôi tìm kiếm các thông tin y khoa và mạnh dạn đề xuất Hội chứng Ekbom trên bệnh nhân này.

Điêu trị: Tính đến năm 2019, chưa có bất kỳ nghiên cứu nào so sánh các phương pháp điều trị có sẵn với giả dược. ${ }^{7}$

Phương pháp điều trị chủ yếu có thể chữa khỏi và hiệu quả nhất là dùng thuốc chống loạn thần liều thấp. Risperidone là lựa chọn hàng đầu cho điều trị. Trong nhiều năm, phương pháp điều trị được lựa chọn là pimozide, nhưng nó có tác dụng phụ cao hơn so với các thuốc chống loạn thần mới hơn. ${ }^{8}$ Aripiprazole và ziprasidone có hiệu quả nhưng chưa được nghiên cứu kỹ về hội chứng Ekbom. Olanzapine cũng có hiệu quả. Tất cả đều được sử dụng với liều lượng thấp nhất có thể, và tăng dần cho đến khi các triệu chứng thuyên giảm.

Liệu pháp nhận thức hành vi (CBT) cũng có thể hữu ích. Bệnh nhân của chúng tôi được điều trị với các thuốc chống trầm cảm và an thần kinh trong đó chúng tôi chọn Fluvoxamine và Quetiapine. Cả 2 thuốc có tác dụng an dịu, liều thấp đáp ứng trên bệnh nhân tốt: ngủ tốt hơn, đõ than phiền, ít ảnh hưởng tới chuyển hoá (đái tháo đường typ2). Kèm theo bệnh nhân và người chăm sóc được chuyển chuyên khoa Tâm thần, được thăm khám, giải thích, động viên của nhân viên tại viện, sau 2 tuần các triệu chứng có thuyên giảm.

Tiên lượng: Thời gian trung bình của tình trạng này là khoảng 3 năm. Tình trạng này dẫn đến sự cô lập xã hội và ảnh hưởng đến việc làm. Có thể chữa khỏi bằng thuốc chống loạn thần hoặc bằng cách điều trị các bệnh tiềm ẩn.

Chúng tôi giữ liên lạc và hẹn khám lại bệnh nhân để đánh giá lại các triệu chứng cũng như kết quả điều trị ngoại trú.

\section{KINH NGHIỆM VÀ KIẾN NGH!}

1. Đối với những bệnh nhân có biểu hiện như trên đặt ra cho các bác sĩ cần thăm khám kỹ và hỏi bệnh sử chi tiết để phát hiện về triệu chứng cơ thể và cả triệu chứng tâm thần.

2. Khi đã phát hiện bệnh nhân không có yếu tỗ về truyền nhiễm hay ảnh hưởng bởi bệnh cơ thể thì khám và tư vấn về vấn đề tâm thần là cần thiết.

3. Quá trình điều trị bệnh nhân trên và tham khảo y văn thấy được khó khăn khi bệnh nhân không thừa nhận bệnh, không hợp tác điều trị và bệnh ảnh hưởng gia đình. Đó cũng là thách thức của bệnh đối với các bác sĩ cần tìm hiểu và nghiên cứu.

\section{TÀI LIỆU THAM KHẢO}

1. Moriarty N, Alam M, Kalus A, O'Connor $K$. Current Understanding and Approach to Delusional Infestation. The American Journal of Medicine. 2019;132(12):1401-1409.

doi:10.1016/j.amjmed.2019.06.017

2. Olivera MJ, Porras Villamil JF, López Moreno GA, Toquica Gahona CC, Paez Ardila $H$, Maldonado Lara E. Delusional infestation. Ekbom's syndrome in a 47-year-old woman. Case report. Case reports. 2017;3(2):114-125. doi:10.15446/ cr.v3n2.62754 
3. Orsolini L, Gentilotti A, Giordani M, Volpe U. Historical and clinical considerations on Ekbom's syndrome. International Review of Psychiatry. 2020;32(5-6):424-436. doi:10.1080/09540261.2020.1757306

4. Reich A, Kwiatkowska D, Pacan P. Delusions of Parasitosis: An Update. Dermatol Ther (Heidelb). 2019;9(4):631-638. doi:10.1007/s13555-019-00324-3

5. Sawant NS, Vispute CD. Delusional parasitosis with folie à deux: A case series. Ind Psychiatry J. 2015;24(1):97-98. doi:10.4103/0972-6748.160950

6. Campbell EH, Elston DM, Hawthorne JD,
Beckert DR. Diagnosis and management of delusional parasitosis. Journal of the American Academy of Dermatology. 2019;80(5):1428-1434. doi:10.1016/j.jaad.2018.12.012

7. Assalman I, Ahmed A, Alhajjar R, Bewley AP Taylor R. Treatments for primary delusional infestation. Cochrane Database Syst Rev. 2019:2019(12):CD011326.

doi:10.1002/14651858.CD011326.pub2

8. Bellanger A-P, Crouzet $J$, Boussard $M$, et al. Ectoparasitosis or Ekbom syndrome? Can Fam Physician. 2009;55(11):1089-1092.

\section{KẾT QUẢ KIỂM SOÁT GLUCOSE MÁU Ở TRẺ ĐÁI THÁO ĐƯỜNG SƠ SINH TẠI BỆNH VIỆN NHI TRUNG ƯƠNG}

\section{TÓM TẮT}

Kiểm soát glucose máu (KSGM) ở mức tối ưu là muc tiêu cơ bản để điều trị và quản lý bênh đái tháo đường. KSGM tốt cho trẻ mắc đái tháo đường sơ sinh (ĐTĐSS) giúp trẻ ngăn ngừa các biến chứng. Mục tiêu: Nhận xét kết quả KSGM ở trẻ ĐTĐSS tại bệnh viện Nhi Trung ương. Phương pháp: mô tả một loat ca bệnh. Kết quả: $94,1 \%$ bệnh nhân đột biến $\mathrm{ABCC} 8 / \mathrm{KCNJ11}$ đạt mức KSGM tốt khi điêuu trị bằng SU, 1 bênh nhân chưa phát hiên gen đôt biến đước điều trị với SU có mức KSGM ban đâu tốt, khi chuyển đổi sang insulin có mức glucose máu tốt nhưng $\mathrm{HbA} 1 \mathrm{c}$ kém. Khi điêu trị bằng insulin có $37,5 \%$ (dựa vào HbA1c), 25\% (dưa vào glucose máu) bênh nhân có đột biến gen khác đạt mục tiêu KSGM. 2/7 bệnh nhân không có đôt biến gen đã được dừng thuổc nhưng phải tái sử dụng insulin trong những đợt nhiễm trùng cấp. $100 \%$ bểnh nhân có bất thường $6 q 24$ được KSGM tốt trước khi dừng thuốc, chưa có bệnh nhân nào tái phát. Không bênh nhân nào hạ glucose máu năng, ha glucose máu không triệu chứng gặp chủ yếu ở nhóm điều trị bằng insulin.

Từ khoá: đái tháo đường sơ sinh, kiểm soát glucose máu, insulin, sulfonylurea

\section{SUMMARY \\ RESULTS OF GLYCEMIC CONTROL IN NEONATAL DEABETES MELLITUS ATNATIONAL CHILDREN'S HOSPITAL}

Glycemic control (GC) is the primary goal for the regulation and management of diabetes. Good glycemic control for children with neonatal diabetes mellitus (NDM) helps prevent complications. Objectives: Review the results of GC in NDM children at the National Children's Hospital. Method: Cases

${ }^{1}$ Trường Đại học Y Hà Nội

²Bênh viện Nhi Trung ương

Chịu trách nhiệm chính: Cấn Thị Bích Ngọc

Email: ngocctb@nhp.org.vn

Ngày nhận bài: 6.8.2021

Ngày phản biên khoa hoc: 4.10 .2021

Ngày duyệt bài: 12.10.2021

\section{Nguyễn Thị Hoài ${ }^{1}$, Cấn Thị Bích Ngọc ${ }^{2}$}

series report. Results: $94.1 \%$ of patients carrying ABCC8/KCNJ11 mutations achieved good GC levels when treated with $\mathrm{SU}$, one patient with undetected mutant genes treated with SU had good baseline blood glucose levels, when converted to insulin had good blood glucose levels but poor HbA1c. When treated with insulin, 37.5\% (HbA1c-based) and 25\% (blood-glucose-based) patients with other gene mutations reached the GMG target. 2/7 patients without genetic mutations were stopped but had to restart insulin during acute infections. $100 \%$ of patients with 6q24 abnormality had a good GC before stopping the drug, no patients had relapsed. There were no patients with severe hypoglycaemia, asymptomatic hypoglycaemia was seen mainly in insulin-treated patients.

Key world: Neonatal diabetes mellitus, glycemic control, insulin, sulfonylurea

\section{I. ĐĂT VẤN ĐỀ}

Đái tháo đường sơ sinh (ĐTĐSS) là tình trạng tăng glucose máu dai dẳng, khởi phát trước 12 tháng tuổi. Nguyên nhân gây bệnh do đột biến gen. Tỷ lệ mắc từ $1 / 90000-1 / 160000$ trẻ đẻ sống với $80 \%$ bệnh nhân mang bệnh vĩnh viễn suốt đời và $20 \%$ bênh nhân có thể khỏi bênh sau một thời gian điều trị, mặc dù có thể tái phát ở tuổi dậy thi ${ }^{1}$.

Trẻ được chẩn đoán mắc ĐTĐSS đều được điều trị bằng insulin ở thời điểm chẩn đoán. Sau đó, tuỳ thuộc kết quả phân tích gen sẽ có phương pháp điều trị khác nhau: bệnh nhân có đột biến gen mã hóa cho kênh KATP sẽ được chuyển đổi sang uống sulfonylurea (SU), bênh nhân có bất thường 6q24 sẽ được theo dõi sát để xác định thời điểm dừng thuốc, những bệnh nhân có các đột biến gen khác hoặc không có đột biến gen sẽ tiếp tục điều trị bằng insulin ${ }^{1,2}$.

Mục tiêu điêu trị ĐTĐSS là phải kiểm soát, duy trì glucose máu ở mức tối ưu nhằm ngăn ngừa các biến chứng, nhưng đồng thời phải đảm 
bảo được sự phát triển của trẻ. Tuy nhiên, việc kiểm soát glucose máu (KSGM) còn gặp nhiều khó khăn, bởi đặc thù tuổi nhỏ, glucose máu dao động do trẻ ăn liên tục lại nhạy cảm với insulin, cùng với việc phải điều trị lâu dài đòi hỏi tuân thủ điều trị nghiêm ngặt. Từ thực tế trên chúng tôi thực hiện nghiên cứu này với mục tiêu:

Nhận xét kêt quả kiểm soát glucose máu ở trẻ đái tháo đường sơ sinh tại Bệnh viện Nhi Trung ương.

\section{II. ĐỐI TƯớNG VÀ PHƯƠ'NG PHÁP NGHIÊN CỨU}

Đối tượng. 39 trẻ được chẩn đoán ĐTĐSS và được theo dõi điều trị ngoại trú tại khoa Nội tiết - Chuyển hóa-Di truyền, Bệnh viện Nhi Trung ương từ tháng 7-2020 đến tháng 8-2021.

\section{Tiêu chuẩn lựa chọn}

+ Các bệnh nhân được chẩn đoán ĐTĐSS ${ }^{1}$ :

- Tăng glucose máu xuất hiện trước 12 tháng tuổi

- Glucose máu đói $\geq 7,0 \mathrm{mmol} / \mathrm{l}$; (đói được định nghĩa là không ăn ít nhất 4 giờ ở trẻ $0 \div 1$ tuổi) hoặc glucose máu bất kỳ $\geq 11,1 \mathrm{mmol} / \mathrm{l}$;

- Trẻ sơ sinh tăng glucose máu khi đói kéo dài $>14$ ngày phải điều trị bằng insulin ${ }^{1,2}$.

+ Thời gian điều trị $\geq 9$ tháng; Bệnh nhân và gia đình đồng ý tham gia nghiên cứu.

Phương pháp. Nghiên cứu mô tả một loạt ca bệnh

Các thông tin thu thập:Thông tin chung gồm: tuổi, giới, thời gian mắc bệnh; kết quả phân tích gen được thực hiê̂n tại đại học Exeter - Anh.

Glucose máu 5 mâ̂u/ngày tại nhà và $\mathrm{HbA1c} 3$ tháng 1 lần tại khoa sinh hoá Bệnh viện Nhi Trung ương để đánh giá kết quả KSGM;

Mức độ KSGM được đánh giá theo hướng dẫn của hiệp hội ĐTÐ trẻ em và vị thành niên thế giới (ISPAD) năm 2014²:

- KSGM lý tưởng (không ĐTĐ):
- Lâm sàng: không có biểu hiện tăng hoặc hạ glucose máu

- Glucose máu: Lúc đói: 3,6-5,6mmol/l; sau ăn: 4,5-7,0mmol/l; trước ngủ: 4,0-5,6mmol/l; ban đêm: 3,6-5,6mmol/l

- HbA1c: $<6,5 \%$

- KSGM tốt:

- Lâm sàng: Không triệu chứng, hạ glucose máu không nặng

- Glucose máu: Lúc đói: 4-8 mmol/l; sau ăn: 5-10 mmol/l; trước ngủ: 6,7-10mmol/l; ban đêm: $4,5-9 \mathrm{mmol} / \mathrm{l}$

- HbA1c: $<7,5 \%$

- KSGM trung bình:

- Lâm sàng: Đái nhiều, uống nhiều, đái dầm; hạ glucose máu nặng, hôn mê hoặc co giật

- Glucose máu: Lúc đói: $>8 \mathrm{mmol} / \mathrm{l} ;$ sau ăn: 10-14 mmol/l; trước ngủ: $<4,2$ hoặc $>9 \mathrm{mmol} / \mathrm{l}$; ban đêm: $<4,2$ hoặc $>9 \mathrm{mmol} / \mathrm{l}$

- HbA1c: 7,5-9\%

- KSGM kém:

- Lâm sàng: Nhìn mờ, tăng cân kém, tăng trưởng chậm, chậm dậy thì, giảm chú ý, nhiễm trùng da và tiết niệu, biến chứng mạch máu; hạ glucose máu nặng, hôn mê hoặc co giật

- Glucose máu: Lúc đói: $>9 \mathrm{mmol} / \mathrm{l} ;$ sau ăn: $>14$ mmol/l; trước ngủ: $<4,4$ hoặc $>11 \mathrm{mmol} / \mathrm{l}$; ban đêm: $<4,0$ hoặc $>11 \mathrm{mmol} / \mathrm{l}$

- HbA1c: $>9 \%$

\section{KẾT QUẢ NGHIÊN CỨU}

39 bệnh nhân được chia thành 4 nhóm:

Nhóm I: Bệnh nhân có đột biến gen mã hoá cho kênh KATP: $A B C C 8 / K C N J 11$

Nhóm II: Bệnh nhân có bất thường 6q24

Nhóm III: Bệnh nhân có đột biến gen khác: INS

Nhóm IV: Bệnh nhân không có đột biến gen

\section{Đặc điểm chung}

Bảng 1. Đặc điểm chung của nhóm nghiên cứu

\begin{tabular}{|c|c|c|c|c|}
\hline Đặc điểm & $\begin{array}{l}\text { Nhóm I } \\
(n=18)\end{array}$ & $\begin{array}{l}\text { Nhóm II } \\
(n=6)\end{array}$ & $\begin{array}{c}\text { Nhóm III } \\
(n=8)\end{array}$ & $\begin{array}{l}\text { Nhóm IV } \\
(n=7)\end{array}$ \\
\hline $\begin{array}{c}\text { Tuối chấn đoán (Tháng) } \\
T B \pm S D \text { (min-max) }\end{array}$ & $\begin{array}{l}1,94 \pm 1,34 \\
(0,13-5,41) \\
\end{array}$ & $\begin{array}{l}0,77 \pm 0,44 \\
(0,3-1,44) \\
\end{array}$ & $\begin{array}{c}4,85 \pm 4,07 \\
(0,66-11,9\end{array}$ & $\begin{array}{l}3,05 \pm 2,48 \\
(0,13-6,69) \\
\end{array}$ \\
\hline $\begin{array}{l}\text { Tuối hiện tại (năm) } \\
\mathrm{TB} \pm \mathrm{SD}^{\prime}(\min -\mathrm{max})\end{array}$ & $\begin{array}{c}5 \pm 2,88 \\
(1,26+11,39)\end{array}$ & $\begin{array}{c}3,31 \pm 2,45 \\
(1,04-7,75)\end{array}$ & $\begin{array}{l}5,19 \pm 3,55 \\
(1,36-10,2)\end{array}$ & $\begin{array}{c}3,85 \pm 2,31 \\
(1,41-7,7,13)\end{array}$ \\
\hline $\begin{array}{l}\text { Thời gian điều trị insulin } \\
\text { (Tháng) } T B \pm S D \text { (min-max) }\end{array}$ & $\begin{array}{c}5,09 \pm 6,4 \\
(0,97-22,67)\end{array}$ & $\begin{array}{c}11,77 \pm 8,82 \\
(1,03-27,33)\end{array}$ & $\begin{array}{l}57,12 \pm 42,2 \\
(9,73-117,87\end{array}$ & $\begin{array}{c}29,07 \pm 2,49 \\
(6,97-77,8\end{array}$ \\
\hline $\begin{array}{c}\text { Thời gian điều trị SU (Tháng) } \\
\qquad \mathrm{TB} \pm \mathrm{SD} \text { (min-max) }\end{array}$ & $\begin{array}{c}42,13 \pm 3,52^{*} \\
(5,2-131,1)\end{array}$ & 0 & 0 & 9.6 \\
\hline
\end{tabular}

*1 bệnh nhân không đáp ứng với liệu pháp SU, 6 bệnh nhân đã được dừng thuốc.

Nhận xét: Tuổi chẩn đoán thấp nhất ở nhóm II và lớn nhất ở nhóm III. Nhóm III có thời gian điều trị insulin dài nhất. Các bệnh nhân có đột biến $A B C C 8 / K C N J 11$ hầu hết đều được chuyển đổi thành công sang SU với thời gian điều trị trung bình là $42,13 \pm 3,52$ tháng. 1 bệnh nhân chưa phát hiện đột biến gen được điều trị bằng SU trong 9,6 tháng. 


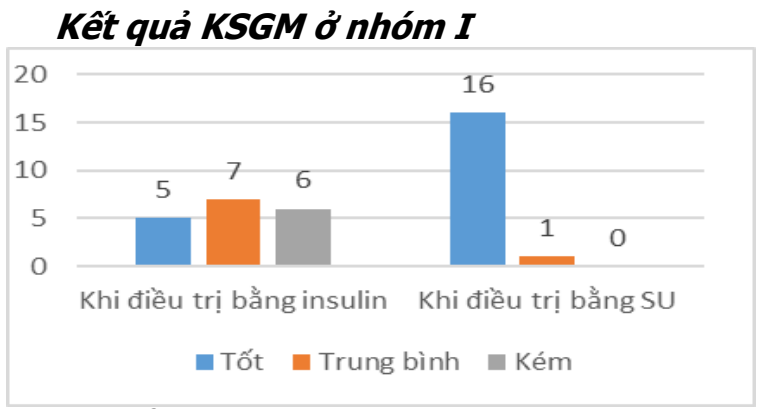

Biểu đồ 5. Kêt quả KSGM ở nhóm I

Nhận xét: Khi điều trị bằng insulin, bệnh nhân có mức KSGM kém và trung bình chiếm tỷ lệ cao (72,2\%). Khi điều trị bằng SU, chỉ có 1 bệnh nhân $(5,9 \%)$ KSGM trung bình, không có bệnh nhân KSGM kém.

Kêt quả KSGM ở nhóm II

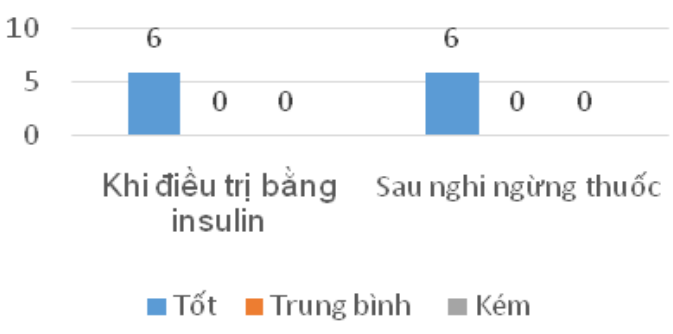

\section{Biểu đồ 4 Kêt quả KSGM ở nhóm II}

Nhận xét: $100 \%$ bệnh nhân được KSGM tốt khi điều trị bằng insulin, sau khi dừng thuốc 100\% bệnh nhân vẫn đạt mức KSGM tốt.
Kêt quả KSGM ở nhóm III

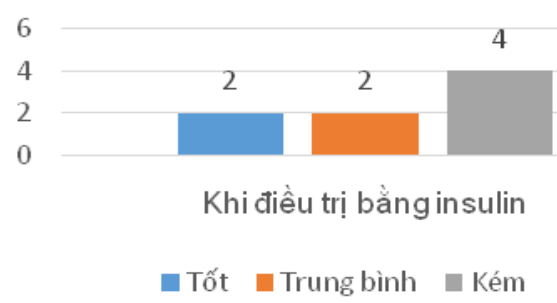

Biểu đồ 5. Kêt quả KSGM ở nhóm III

Nhận xét: Tỷ lệ bệnh nhân có mức KSGM kém và trung bình cao (75\%).

\section{Kêt quả KSGM ở nhóm IV}

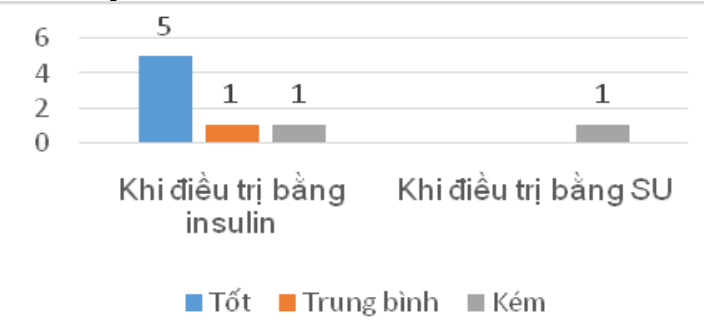

Biểu đồ 6. Kêt quả KSGM ở nhóm IV

Nhận xét: khi điêu trị bằng insulin, bệnh nhân có mức KSGM tốt chiểm tỷ lệ cao $(71,4 \%)$. Một bệnh nhân được điều trị với liệu pháp SU và có kết quả KSGM kém.

\section{Kết quả KSGM theo HbA1c}

Bảng 2. Kêt quả KSGM theo HbA1c

\begin{tabular}{|c|c|c|c|c|c|c|}
\hline \multirow{2}{*}{ Mức KSG } & \multicolumn{2}{|c|}{ BN điêu trị băng insulin } & \multicolumn{3}{c|}{ BN điều trị băng SU } \\
\cline { 2 - 7 } Nhóm & Tốt & Trung bình & Kém & Tốt & Trung bình & Kém \\
\cline { 2 - 7 } & $\mathbf{n ~ ( \% )}$ & $\mathbf{n ~ ( \% )}$ & $\mathbf{n ( \% )}$ & $\mathbf{n}(\%)$ & $\mathbf{n}(\%)$ & $\mathbf{n}(\%)$ \\
\hline Nhóm I $\mathrm{n}=18)$ & 0 & $1(100)$ & 0 & $16(94,1)$ & $1(5,9)$ & 0 \\
\hline Nhóm II $(\mathrm{n}=6)$ & $6(100)$ & 0 & 0 & 0 & 0 & 0 \\
\hline NhómIII $(\mathrm{n}=8)$ & $3(37,5)$ & $2(25)$ & $3(37,5)$ & 0 & 0 & 0 \\
\hline Nhóm V(n=7 & $5(71,4)$ & 0 & $2(28,6)$ & 0 & 0 & $1(100)$ \\
\hline
\end{tabular}

Nhận xét: Bệnh nhân nhóm I có $16 \%$ được KSGM tốt và 5,9\% KSGM trung bình khi điêuu trị bằng SU, 1 bệnh nhân điều trị với insulin có mức KSGM trung bình. $100 \%$ bệnh nhân nhóm II đạt mức KSGM tốt, Nhóm 3 có mức KSGM kém còn cao (37,5\%). Trong nhóm IV chỉ có 1 bệnh nhân điều trị bằng SU và có kết quả KSGM kém, các bệnh nhân điều trị với insulin có 2 bệnh nhân KSGMM kém $(28,6 \%)$

Một số biến chứng do KSGM

Bảng 3. Tỷ lệ hạ glucose máu không triệu chứng

\begin{tabular}{|c|c|c|c|c|}
\hline \multirow[t]{3}{*}{ Hạ glucose máu } & \multicolumn{2}{|c|}{ Điêu trị insulin } & \multicolumn{2}{|c|}{ Điêu tri SU } \\
\hline & Có & Không & Có & Không \\
\hline & n (\%) & n (\%) & n (\%) & n (\%) \\
\hline Nhóm I $(n=18)$ & $1(100)$ & 0 & $2(11,8)$ & $15(88,2)$ \\
\hline Nhóm II $(\mathrm{n}=6)$ & 0 & 0 & 0 & 0 \\
\hline Nhóm III $(\mathrm{n}=8)$ & $5(62,5)$ & $3(37,5)$ & 0 & 0 \\
\hline Nhóm IV $(n=7)$ & $2(28,6)$ & $5(71,4)$ & 0 & $1(100)$ \\
\hline
\end{tabular}

Nhận xét: Khôngbệnh nhân nào có cơn hạ glucose máu nặng, tỷ lệ hạ glucose máu không triệu chứng chủ yếu gặp ở bệnh nhân điều trị bằng insulin, cao nhất ở nhóm İII. 


\section{BÀN LUÂN}

Đặc điểm chung. Với đặc điểm khởi phát sớm đưới 12 tháng tuô̂i ${ }^{1}$, thời gian mắc của bệnh nhân ĐTĐSS không có sự khác biệt nhiều so với tuổi hiện tại. Nghiên cứu của Bingyan Cao: tuổi trung bình là $4 \pm 2,9$ tuổi, thời gian mắc bênh là $3,8 \pm 2,9$ năm$^{3}$; Fiona Tran: tuổi trung bình là 3,9 tuổi, trong đó chỉ $16,67 \%$ bệnh nhân có thời gian điều trị > 5 năm ${ }^{4}$. Theo bảng 1 , tuổi chẩn đoán trong nghiên cứu của chúng tôi phần lớn dưới 6 tháng tuổi, trong đó nhóm II được chẩn đoán sớm nhất. Tuổi hiện tại của 4 nhóm hầu hết đều $<10$ tuổi. Thời gian điều trị insulin dài nhất ở nhóm III. Bệnh nhân được điều trị với SU có thời gian điều trị là 42,13 $\pm 3,52$ tháng (nhóm I) và 9,6 tháng (nhóm IV). Như vậy kết quả của chúng tôi phù hợp với kết quảcủa Bingyan $\mathrm{CaO}^{3}$ và Fiona Tran ${ }^{4}$.

Kết quả KSGM. Việc tìm ra các gen gây ĐTĐSS đã tạo bước ngoặt lớn trong chẩn đoán, điều trị và tiền lượng cho bệnh nhân ĐTĐSS. Với 90 -95\% bệnh nhân mang đột biến gen mã hoá cho kênh $K_{\text {ATP }}$ được điều trị thành công bằng liệu pháp SU và có thể đạt mức KSGM tốt, glucose máu ít dao động hớn so với điều trị bằng insulin ${ }^{1}$. Điều này đã được chứng minh qua nhiều nghiên cứu trước: Bingyan Cao: 94\% bệnh nhân đat mức KSGM tốt khi điều trị với SU3; Cấn Thi Bích Ngọc: 23 bệnh nhân ĐTĐSS do 5 đột biến gen khác nhau có tỷ lệ KSGM tốt là 30,4\% khi điều trị bằng insulin, $87,5 \%$ khi điều trị bằng SU6. Trong nghiên cứu này, các bệnh nhân có đột biến gen mã hoá cho kênh KATP khi được điều trị bằng insulin có mức KSGM chưa tốt (33,3\% kém, $38,9 \%$ trung bình) cao hơn khi được chuyển đối sang uống SU $(5,9 \%$ KSGM trung bình, không có bệnh nhân KSGM kém); chỉ 1 bệnh nhân có đột biến gen KCNJ11 không đáp ứng với SU có mức KSGM trung bình khi điều trị bằng insulin (biểu đồ 1). Đồng thời, theo biểu đồ 3 , có tới $50 \%$ bệnh nhân có kết quả KSGM kém và $25 \%$ KSGM trung bình khi điều trị insulin. Như vậy, kết quả này của chúng tôi tương đồng với các nghiên cứu của Bingyan $\mathrm{Cao}^{3}$ và Cấn Thị Bích $\mathrm{Ngọc}^{6}$.

Trong các nguyên nhân di truyền đã được biết, bất thường 6q24 thường gây ĐTĐSS tạm thời và có thể tái phát sau này ${ }^{1} .6$ bệnh nhân có bất thường 6q24 trong nghiên cứu của chúng tôi đều đạt mức KSGM tốt (biểu đồ 2) trước khi dừng thuốc, chưa có bệnh nhân nào tái phát, glucose máu ổn đinh (từ $4-7 \mathrm{mmol} / \mathrm{l}$ ) có thể do tuổi hiện tại của các bệnh nhân này còn nhỏ (lớn nhất 7,75 tuổi), do đó cần theo dõi trong thời gian dài hơn.
Trên thế giới đã có nhiều nghiên cứu cho thây lợi ích của việc điều trị sớm theo kinh nghiệm bằng SU.Miaoying Zhang: 3 bệnh nhân chưa tìm thấy đột biến gen đã được KSGM tốt bằng liệu pháp SU'7. Trong nghiên cứu của chúng tôi, 1 bệnh nhân chưa tìm thấy đột biến đã có kết quả KSGM tốt trong 9,6 tháng bằng SU đơn trị liệu mà không cần phải dùng tới insulin (glucose máu ổn định 4,5-10mmol/l, HbA1c $6,38 \%$ ). Tuy nhiên sau đó glucose máu dao động $(4,2-27,8 \mathrm{mmol} / \mathrm{l})$, bệnh nhân được theo dõi sát để chỉnh liêu SU nhưng hiệu quả đáp ứng kém và phải chuyển đổi sang liệu pháp insulin. Cho đến thời điểm kết thúc nghiên cứu, mặc dù đã được điều trị insulin liều 0,54UI/ngày cùng với việc kiểm soát tốt chế độ ăn và không có bệnh nhiễm trùng cấp tính, các mẫu xét nghiệm glucose máu mao mạch hằng ngày đều đạt mục tiêu $(5,5-10 \mathrm{mmol} /)$ nhưng $\mathrm{HbA1c}$ lại cho thấy mức KSGM kém (HbA1c 10,21\%). Điều này chứng tỏ glucose máu chỉ phản ánh kết quả tại thời điểm làm xét nghiệm, HbA1c mới đánh giá được hiệu quả KSGM trong 3 tháng và cũng minh chứng rằng việc KSGM ở trẻ ĐTĐSS là vô cùng phức tạp, khó khăn. Theo biểu đồ $4 ; 7$ bệnh nhân được điều trị bằng insulin có $14,3 \%$ KŚGM kém và $14,3 \%$ trung bình. Trong số này, 2 bênh nhân đã được dừng thuốc ở thời điểm 7 và 21 tháng, glucose máu khi không dùng insulin từ 4,3-7mmol/l. Tuy nhiên cả 2 bệnh nhân này đều phải tái sử dụng insulin trong những đợt bệnh tress cấp tính. Các bệnh nhân này hiện vẩn đang được tiếp tục phân tích gen bằng kỹ thuật giải trình tự toàn bộ hệ gen biểu hiện tại đại học Exeter- Anh và kêtt quả sẽ được báo cáo trong các nghiên cứu tiếp theo.

Theo bảng 2, khi đánh giá mức độ KSGM bằng $\mathrm{HbA1c}$; 5,9\% bệnh nhân nhóm I được KSGM máu trung bình. Kết quả này tương đương với kết quả khi đánh giá KSGM bằng chỉ số glucose (biểu đồ 1). Riêng các bệnh nhân được điều trị bằng insulin ở nhóm III $(37,5 \%$ KSGM kém) và IV (28,6\% KSGM kém) có sự chênh lệch so với kết quả khi đánh giá bằng chỉ số glucose (50\% và $14,3 \%)$. Sở dĩ có sự khác nhau này vì glucose máu chỉ phản ánh tại một thời điểm, trong khi HbA1c phản ánh glucose máu trung bình trong 3 tháng trước đó.

Để khảo sát rõ hơn về một số biến chứng do ảnh hưởng của KSGM, chúng tôi tiến hành phân tích tỷ lệ hạ glucose máu. Trong nghiên cứu này, không bệnh nhân nào xuất hiện cơn hạ glucose máu nặng. Theo bảng 3, tỷ lệ hạ glucose máu không triệu chứng gặp chủ yếu ở nhóm được 
điều trị bằng insulin, tỷ lệ cao nhất ở nhóm III với $62,5 \%$, các bệnh nhân được điều trị bằng $S U$ gặp ít hơn $(18,1 \%)$. Kết quả này của chúng tôi phù hợp với nghiên cứu củaBingyan $\mathrm{CaO}^{3}$ và Ewan R. Pearson ${ }^{5}$. Điều này xảy ra do đặc thù trẻ nhỏ, nhạy cảm với insulin và đường máu dao động bởi chế độ ăn thường xuyên của trẻ.

Trong nghiển cứu của S.E Flanagan có tới 14\% bệnh nhân ĐTĐSS do bất thường 6 q24 có biểu hiện hạ glucose máu sau khi dừng thuốc ${ }^{8}$. Tuy nhiên 6 bệnh nhân bất thường 6q24 trong nghiên cứu của chúng tôi không có trường hợp nào xuất hiện cơn hạ glucose máu trong thời gian theo dõi cũng như không phải tái sử dụng thuốc trong những đợt stress bởi nhiễm trùng.

\section{KẾT LUÂN}

KSGM đạt mục tiêu ở 94,1\% bệnh nhân có đột biến $A B C C 8 / K C N J 11$ khi điều trị với SU (dựa vào glucose máu và $\mathrm{HbA1c}$ ); ở các bệnh nhẩn mang đột biến khác là $37,5 \%$ (dựa vào HbA1c), $25 \%$ (dựa vào glucose máu); các bệnh nhân không có đột biến là $71,4 \%$ (dựa vào $\mathrm{HbA1c}$ và glucose máu). $100 \%$ bệnh nhân có bất thường 6q24 được KSGM tốt trước khi dừng thuốc, chưa có bênh nhân nào tái phát. 2/7 bệnh nhân không có đột biến gen đã được dừng thuốc nhưng phải tái sử dụng insulin trong những đợt nhiễm trùng cấp tính; 1 bệnh nhân chưa phát hiện đột biến điều trị bằng SU có mức KSGM ban đầu tốt, khi chuyển đổi sang insulin có mức glucose máu tốt nhưng HbA1c kém. Không có bệnh nhân hạ glucose máu nặng, hạ glucose máu không triệu chứng gặp chủ yếu ở nhóm điều trị bằng insulin.
Cần chỉ định phân tích gen cho trẻ mắc đái tháo đường trong vòng 12 tháng đầu sau đẻ để lựa chọn phương pháp điều trị thích hợp.

\section{TÀI LIÊU THAM KHẢO}

1. Dahl A, Kumar S. Recent Advances in Neonatal Diabetes. Diabetes Metab Syndr Obes. 2020;13:355-364. doi:10.2147/DMSO.S198932

2. Rewers MJ, Pillay $K$, de Beaufort $C$, et al. ISPAD Clinical Practice Consensus Guidelines 2014. Assessment and monitoring of glycemic control in children and adolescents with diabetes. Pediatr Diabetes. 2014;15 Suppl 20:102-114. doi:10.1111/pedi.12190

3. Cao B, Gong $C_{\text {, }}$ Wu D, et al. Genetic Analysis and Follow-Up of 25 Neonatal Diabetes Mellitus Patients in China. J Diabetes Res. 2016;2016:6314368. doi:10.1155/2016/6314368

4. Tran F, Vu DC, Nguyen HT, et al. Glycaemic control in children with neonatal diabetes and type 1 diabetes in Vietnam. Int Health. 2011;3(3):188192. doi: $10.1016 / j$.inhe.2011.03.008

5. Rafiq M, Flanagan SE, Patch A-M, et al. Effective treatment with oral sulfonylureas in patients with diabetes due to sulfonylurea receptor 1 (SUR1) mutations. Diabetes Care. 2008; 31(2):204-209. doi:10.2337/dc07-1785

6. Cân Thị Bích Ngọc. Nghiên cứu đột biến gen, lâm sàng và điêu trị bệnh đái tháo đường sơ sinh.Luận văn tiến sỹ y học, Đại học Y Hà Nội

7. Zhang $M$, Chen $X$, Shen $S$, et al. Sulfonylurea in the treatment of neonatal diabetes mellitus children with heterogeneous genetic backgrounds. J Pediatr Endocrinol Metab. 2015;28(7-8):877-884. doi:10.1515/jpem-2014-0429

8. Flanagan SE, Mackay DJG, Greeley SAW, et al. Hypoglycaemia following diabetes remission in patients with 6q24 methylation defects expanding the clinical phenotype. Diabetologia. 2013; 56(1):218-221. doi:10.1007/s00125-012-2766-z

\title{
NGHIÊN CỨU BIẾN THIÊN NHİP TIM Ở BÊNNH NHÂN BỆNH TIM THIẾU MÁU CỤC Bộ MẠN TÍNH CÓ SUY TIM
}

\author{
Đoàn Thịnh Trường ${ }^{1,2}$, Nguyễn Oanh $\operatorname{Oanh}^{2}$, Nguyễn Quang Toàn ${ }^{3}$
}

\section{TÓM TẮT}

Đối tượng và phương pháp nghiên cứu: gồm 136 bệnh nhân bệnh tim thiếu máu cục bộ mạn tính có suy tim tại Bệnh viện Quân y 103 và Bệnh viện Tim Hà Nội từ 4 năm 2015 đến tháng 1 năm 2021. Các

\footnotetext{
${ }^{1}$ Bệnh viện Đa khoa huyện Hoài Đức

ªệnh viện Quân y 103, Học viện Quân y

${ }^{3}$ Bệnh viện trung ương Thái Nguyên

Chịu trách nhiệm chính: Đoàn Thịnh Trường

Email: bsdoanthinhtruong@gmail.com

Ngày nhận bài: 9.8.2021

Ngày phản biên khoa học: 4.10.2021

Ngày duyệt bài: 14.10.2021
}

bênh nhân tham gia nghiên cứu đáp ứng đủ các tiêu chuẩn chẩn đoán và loại trừ. Kết quả: chỉ số SDNN RMSSD, SDNNi, TP, LF, và tỷ lệ LF/HF sau điều trị (tương ứng là $62,34 \pm 32,16 ; 25,14 \pm 6,10 ; 44,45 \pm$ 13,$48 ; 1956,23 \pm 613,64 ; 1413,94 \pm 174,33 ; 3,03 \pm$ 0,71 ) đều tăng hơn so với trước điều tri (tương ứng là $38,63 \pm 18,2 ; 12,61 \pm 5,39 ; 22,66 \pm 11,47 ; 1347,92 \pm$ $412,53 ; 874,15 \pm 210,32 ; 2,21 \pm 0,68)$ với $p<0,05$. Số nhánh tổn thương càng nhiều các chỉ số biến thiên nhịp tim càng thấp. Giá tri SDNN, SDNNi, TP, HF, LF giảm dần theo số nhánh tổn thương động mạch vành, sư khác biêt có ý nghĩa với $p<0,05$. Nồng đô NTproBNP của bệnh nhân có biến thiên nhịp tim bình thường thấp hớn so với những bệnh nhẩn có giảm biến thiên nhịp tim, $p<0,05$. Kết luận: Các chỉ số 